\section{Pacific Northwest} National Laboratory

Operated by Battelle for the

U.S. Department of Energy

\title{
Contaminant Release Data Package for Residual Waste in Single-Shell Hanford Tanks
}

\author{
W. J. Deutsch \\ K. J. Cantrell \\ K. M. Krupka
}

December 2007

Prepared for CH2M HILL Hanford Group, Inc., and the U.S. Department of Energy under Contract DE-AC05-76RL01830 


\title{
DISCLAIMER
}

This report was prepared as an account of work sponsored by an agency of the United States Government. Neither the United States Government nor any agency thereof, nor Battelle Memorial Institute, nor any of their employees, makes any warranty, express or implied, or assumes any legal liability or responsibility for the accuracy, completeness, or usefulness of any information, apparatus, product, or process diselosed, or represents that its use would not infringe privately owned rights. Reference herein to any specific commercial product, process, or service by trade name, trademark, manufacturer, or otherwise does not necessarily constitute or imply its endorsement, recommendation, or favoring by the United States Government or any agency thereof, or Battelle Memorial Institute. The views and opinions of authors expressed herein do not necessarily state or reflect those of the United States Government or any agency thereof.

\author{
PACIFIC NORTHWEST NATIONAL LABORATORY \\ operated by \\ BATTELLE \\ for the \\ UNITED STATES DEPARTMENT OF ENERGY \\ under Contract DE-AC05-76RL01830 \\ Printed in the United States of America \\ Available to DOE and DOE contractors from the \\ Office of Scientific and Technical Information, \\ P.O. Box 62, Oak Ridge, TN 37831-0062; \\ ph: (865) 576-8401 \\ fax: (865) 576-5728 \\ email: reports@adonis.osti.gov \\ Available to the public from the National Technical Information Service, \\ U.S. Department of Commerce, 5285 Port Royal Rd., Springfield, VA 22161 \\ ph: (800) 553-6847 \\ fax: (703) 605-6900 \\ email: orders@ntis.fedworld.gov \\ online ordering: http://www.ntis.gov/ordering.htm
}

This document was printed on recycled paper.

(9/2003) 


\title{
Contaminant Release Data Package for Residual Waste in Single-Shell Hanford Tanks
}

\author{
W. J. Deutsch \\ K. J. Cantrell \\ K. M. Krupka
}

December 2007

Prepared for CH2M HILL Hanford Group, Inc., and the U.S. Department of Energy

under Contract DE-AC05-76RL01830

Pacific Northwest National Laboratory

Richland, Washington 99352 


\section{Summary}

The Hanford Federal Facility Agreement and Consent Order Milestone M-045-55 requires that a Resource Conservation and Recovery Act (RCRA) Facility Investigation report be submitted to the Washington State Department of Ecology. The RCRA Facility Investigation report will provide a detailed description of the state of knowledge needed for tank farm performance assessments. This data package provides detailed technical information about contaminant release from closed single-shell tanks necessary to support the RCRA Facility Investigation report. It was prepared by Pacific Northwest National Laboratory (PNNL) for CH2M HILL Hanford Group, Inc. (CH2M HILL), which is tasked by the U.S. Department of Energy (DOE) with tank closure.

As part of its Residual Tank Waste Contaminant Release Project funded by CH2M HILL, PNNL has completed characterization and testing of residual waste from four retrieved Hanford single-shell tanks (C-103, C-106, C-202, and C-203). This data package is a compilation of data on contaminant release rates for residual waste from the four tanks tested by PNNL to date. This data package is current as of those studies completed by PNNL through November 29, 2007. The report describes the geochemical properties of the primary contaminants of interest (uranium, technetium-99, iodine-129, chromium, transuranics, and nitrate), the occurrence of these contaminants in the residual waste, release mechanisms from the solid waste to water infiltrating the tanks in the future, and the laboratory tests conducted to measure release rates.

To simulate potential future geochemical conditions in the tanks that might result in leaching of contaminants from the waste, two leaching solutions were used. A $0.01 \mathrm{M} \mathrm{Ca}(\mathrm{OH})_{2}$ leaching solution was used to simulate conditions if the tanks are filled with cement and pore water from the fresh cement then contacts and leaches the residual waste. A calcite $\left(\mathrm{CaCO}_{3}\right)$ saturated solution was used as the other leachant to simulate native Hanford pore water, which is appropriate if the pore water directly contacts the residual waste, the tanks are filled with an inert material, or after the native pore water reacts with aged cement and becomes coated with calcite. It has been found that the type of leaching solution can have a major effect on contaminant release rates in some cases. For example, the maximum release concentration for uranium from tank C-202 residual waste is about 36 times higher for the calcitesaturated leaching solution than for the $0.01 \mathrm{M} \mathrm{Ca}(\mathrm{OH})_{2}$ leaching solution. These results are likely due to an increase in solubility of uranium minerals caused by the lower $\mathrm{pH}$ values (7.6 to 9.0) and high degree of carbonate complexation at the higher carbonate concentrations in the calcite-saturated C-202 test solutions compared to the $0.01 \mathrm{M} \mathrm{Ca}(\mathrm{OH})_{2}$ test solutions ( $\mathrm{pH} 11.5$ to 11.8).

For most of the residual tank waste samples tested to date, the release models that have been developed are primarily empirically based. Development of mechanistic release models has not been possible because, in some cases, the contaminants (especially technetium-99, iodine-129, and chromium) appear to be coprecipitated at trace concentrations in solids that are difficult to characterize and are often amorphous. In other cases where the contaminant is present at higher concentrations (such as uranium), $\mathrm{x}$-ray diffraction analysis and saturation index calculations have not been successful in identifying the solid phase that controls its dissolved concentration in the laboratory leachates. In the case of C-103, it appears that uranium release is controlled by the solubility of schoepite. As a result, a mechanistic release model for this case is possible. In this case, a reactive transport model could be used to simulate future release of uranium based upon the solubility of schoepite and expected pore water compositions. 
Because mechanistic release models have not been possible for most contaminants, quantitative empirical models have been developed from the laboratory test data. These models do not account for the actual release process and are not amenable to modification if actual conditions controlling leachant compositions or release scenarios differ from those under which the empirical models were developed. The report discusses additional testing methodologies for the residual waste that might enable mechanistic contaminant release models to be developed. 


\section{Acknowledgments}

The authors wish to acknowledge F. M. Mann at CH2M HILL Hanford Group, Inc. (Richland, Washington), for providing project funding and technical guidance for preparation of the data package, and M. P. Connelly (CH2M HILL Hanford Group, Inc.), for providing project funding for the PNNL Residual Tank Waste Characterization Project. J. L. Krumhansl (Sandia National Laboratories) provided an excellent, independent, technical review of the entire document. Technical reviews were greatly appreciated and provided by M. P. Connelly (CH2M HILL Hanford Group, Inc.), D. A. Myers (CH2M HILL Hanford Group, Inc.), M. I. Wood (Fluor Hanford, Inc.), and R. J. Serne (Pacific Northwest National Laboratory). Thanks go to A. J. Currie (Pacific Northwest National Laboratory) for completing the editorial review and to L. M. Andor and K. R. Neiderhiser (Pacific Northwest National Laboratory) for final formatting of this technical report. 


\section{Abbreviations and Acronyms}

\begin{tabular}{|c|c|}
\hline AEA & alpha energy analysis \\
\hline $\begin{array}{l}\text { ASTM } \\
\text { am }\end{array}$ & $\begin{array}{l}\text { American Society for Testing and Materials } \\
\text { amorphous }\end{array}$ \\
\hline $\mathrm{BBI}$ & Best Basis Inventory \\
\hline BDL & below detection limit \\
\hline BFS & blast furnace slag \\
\hline BSE & backscattered electron \\
\hline $\mathrm{CCV}$ & continuing calibration verification \\
\hline CH2M HILL & CH2M HILL Hanford Group, Inc. \\
\hline $\mathrm{CSH}$ & calcium silicate hydrogel \\
\hline $\mathrm{COI}$ & contaminant of interest \\
\hline $\mathrm{cr}$ & crystalline \\
\hline DBP & dibutyl phosphate \\
\hline DDI & double deionized (water) \\
\hline DOE & U.S. Department of Energy \\
\hline $\mathrm{DRC}$ & dynamic reaction cell \\
\hline DST & double-shell tank \\
\hline DTPA & diethylenetriaminepentaacetate \\
\hline ED3A & ethylenediaminetriacetate \\
\hline s-EDDA & symmetric ethylenediaminediacetic acid \\
\hline EDS & energy-dispersive (x-ray) spectroscopy \\
\hline EDTA & ethylenediaminetetraacetic acid \\
\hline Eh & $\begin{array}{l}\text { electrical potential }\left(-\log \left\{\mathrm{e}^{-}\right\}\right) \text {, a measure of redox state; relative to the standard } \\
\text { hydrogen electrode in volts or millivolts }\end{array}$ \\
\hline EPA & U.S. Environmental Protection Agency \\
\hline EQL & estimated quantitation limit \\
\hline EXAFS & extended x-ray absorption fine structure spectroscopy \\
\hline $\mathrm{g}$ & gram \\
\hline $\mathrm{g} \mathrm{C} / \mathrm{L}$ & grams of carbon per liter \\
\hline HEDTA & hydroxyethylethylenediaminetriacetic acid \\
\hline $\mathrm{HF}$ & hydrofluoric \\
\hline HFFACO & Hanford Federal Facility Agreement and Consent Order \\
\hline HLW & high-level waste \\
\hline $\mathrm{HM}$ & hazardous material \\
\hline HTWOS & Hanford Tank Waste Operations Simulator \\
\hline
\end{tabular}




\begin{tabular}{|c|c|}
\hline IC & ion chromatography (chromatograph) \\
\hline ICP-MS & inductively coupled plasma-mass spectrometry (spectrometer) \\
\hline ICP-OES & inductively coupled plasma-optical emission spectroscopy (same as ICP-AES) \\
\hline IDA & iminodiacetic acid \\
\hline $\mathrm{K}_{\mathrm{d}}$ & partition coefficient or distribution coefficient; terms commonly used interchangeably \\
\hline LLNL & Lawrence Livermore National Laboratory \\
\hline$\mu \mathrm{g} / \mathrm{g}$ & microgram per gram \\
\hline$\mu \mathrm{SXRF}$ & microscanning x-ray fluorescence \\
\hline$\mu \mathrm{XRF}$ & micro x-ray fluorescence \\
\hline M & molarity, moles of solute per liter solution \\
\hline $\mathrm{m}$ & molality, moles of solute per $1,000 \mathrm{~g}$ solvent \\
\hline $\mathrm{mL}$ & milliliter \\
\hline NA & not applicable; not available \\
\hline NIST & National Institute of Standards and Technology \\
\hline $\mathrm{NPH}$ & normal paraffinic hydrocarbon \\
\hline NTA & nitrilotriacetic acid \\
\hline OPC & ordinary Portland cement \\
\hline PDFTM & powder diffraction file \\
\hline $\mathrm{pH}$ & $-\log \left\{\mathrm{H}^{+}\right\}$, the negative logarithm of hydrogen ion activity \\
\hline pHzpc & $\mathrm{pH}$ for zero point of charge \\
\hline ppb & parts per billion (equivalent to $\mu \mathrm{g} / \mathrm{kg}$ ) \\
\hline ppm & parts per million (equivalent to $\mathrm{mg} / \mathrm{kg}$ ) \\
\hline PNL & $\begin{array}{l}\text { Pacific Northwest Laboratory. In 1995, DOE formally changed the name of the Pacific } \\
\text { Northwest Laboratory to the Pacific Northwest National Laboratory. }\end{array}$ \\
\hline PNNL & Pacific Northwest National Laboratory \\
\hline PUREX & plutonium-uranium extraction \\
\hline RCRA & Resource Conservation and Recovery Act \\
\hline REE & rare earth element \\
\hline RDR & Retrieval Data Report \\
\hline RFI & RCRA Facility Investigation \\
\hline SCM & electrostatic surface complexation model \\
\hline $\mathrm{SE}$ & secondary electron \\
\hline SEM & scanning electron microscopy (or microscope) \\
\hline SI & saturation index \\
\hline SPFT & single-pass flow-through \\
\hline SST & single-shell tank \\
\hline
\end{tabular}


TBP

TEM

TIC

TWINS

XAFS

XANES

XAS

XRD

WMA tributyl phosphate

transmission electron microscopy (or microscope)

total inorganic carbon

Tank Waste Information Network System

x-ray absorption fine structure spectroscopy

$\mathrm{x}$-ray adsorption near edge structure spectroscopy

x-ray absorption spectroscopy

$\mathrm{x}$-ray powder diffractometry analysis (commonly called $\mathrm{x}$-ray diffraction)

waste management area 


\section{Contents}

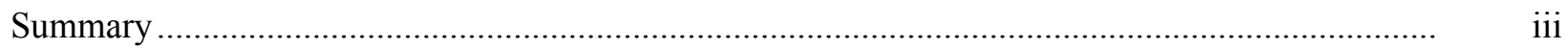

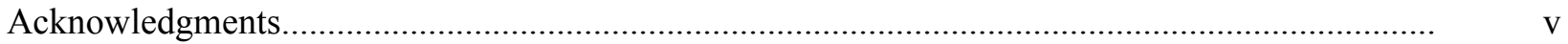

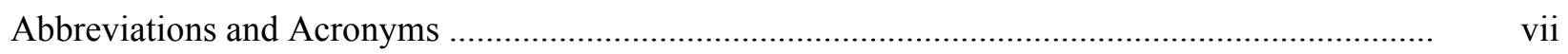

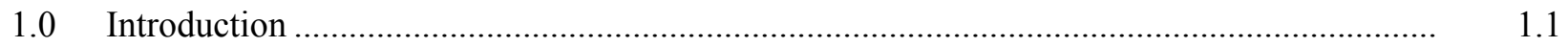

2.0 Hanford Single-Shell Tanks and Residual Waste Characteristics ....................................... 2.1

2.1 Single-Shell Tank Description ............................................................................ 2.1

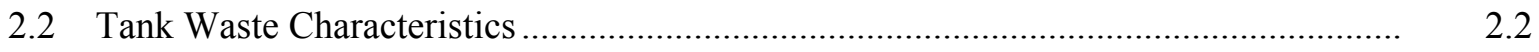

2.2.1 Physical Properties ..................................................................................... 2.2

2.2.2 Chemical Composition ...................................................................................... 2.3

2.2.3 Tank Residual Waste Solid Phase Composition ........................................... $\quad 2.13$

3.0 Geochemistry of Contaminants of Interest in Closed Single-Shell Tanks ............................ 3.1

3.1 Contaminants of Interest Selection Process ............................................................. 3.1

3.2 Geochemical Conditions in Closed Single-Shell Tanks........................................... 3.2

3.2.1 Role of Cementitious Materials................................................................... 3.2

3.2.2 Role of Organic Complexants ..................................................................... 3.3

3.2.3 Potential Adsorbates............................................................................. 3.4

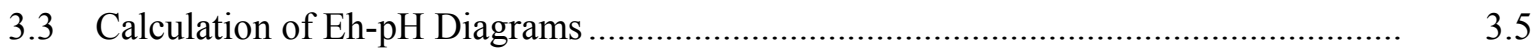

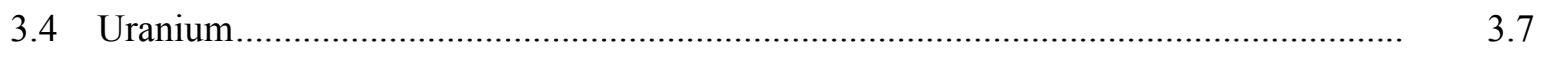

3.4.1 Oxidation States .............................................................................. $\quad 3.7$

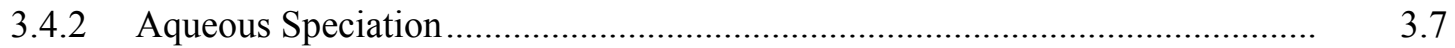

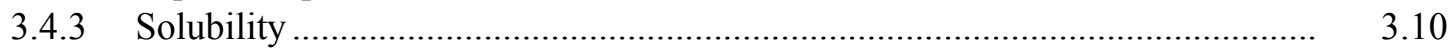

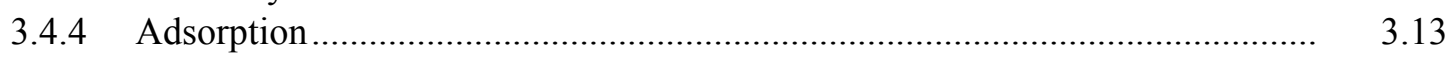

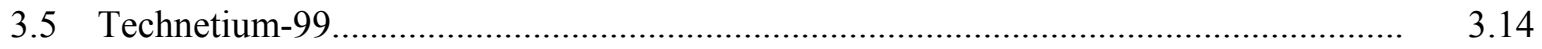

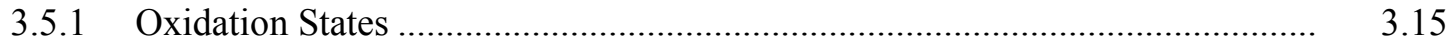

3.5.2 Aqueous Speciation...................................................................................... $\quad 3.15$

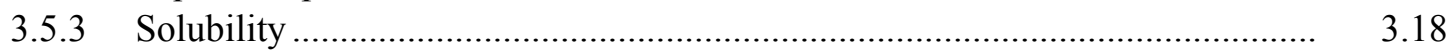

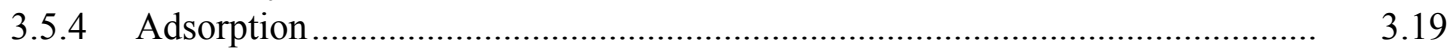

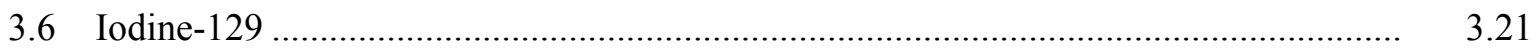

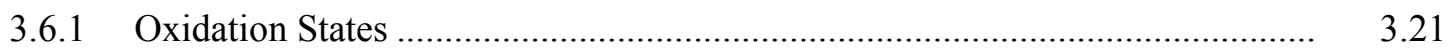

3.6.2 Aqueous Speciation............................................................................... 3.21

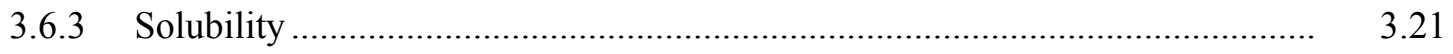

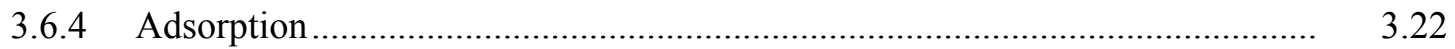

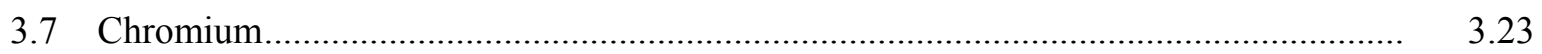

3.7.1 Oxidation States ............................................................................... 3.23

3.7.2 Aqueous Speciation ............................................................................. 3.24

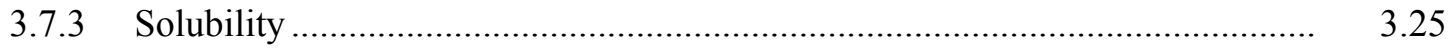

3.7.4 Adsorption ................................................................................ 3.26

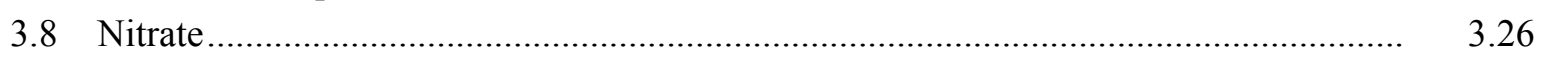

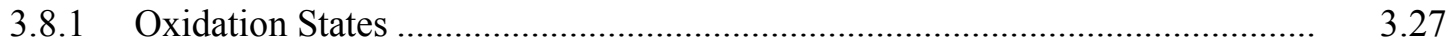

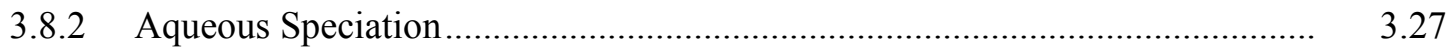

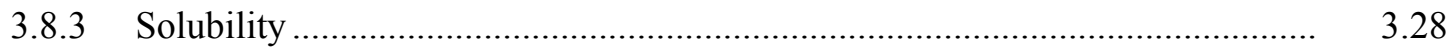




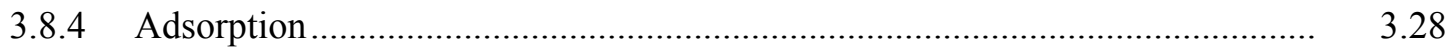

4.0 Residual Waste Testing and Results of Leaching Tests .....................................................

4.1 Chemical and Solid Phase Analyses of Tank Waste ................................................... 4.1

4.2 Contaminants of Interest in C-103 Residual Waste .....................................................

4.2.1 Uranium............................................................................................ 4.2

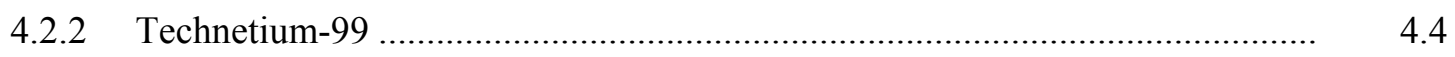

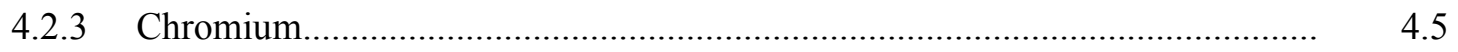

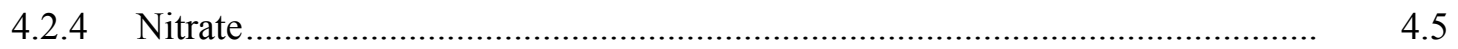

4.2.5 Percentage Leachable Contaminants of Interest............................................. 4.6

4.3 Contaminants of Interest in C-106 Residual Waste ................................................ 4.7

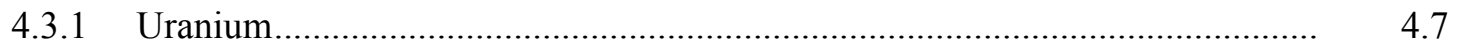

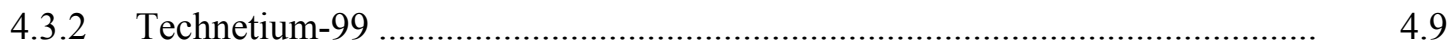

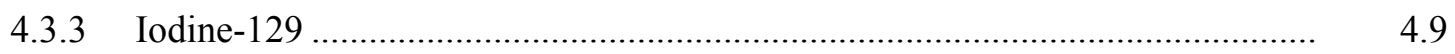

4.3.4 Chromium................................................................................. 4.10

4.3.5 Nitrate ............................................................................................. 4.12

4.3.6 Percentage Leachable Contaminants of Interest............................................... 4.13

4.4 Contaminants of Interest in C-202 Residual Waste ................................................... 4.14

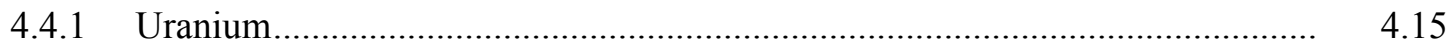

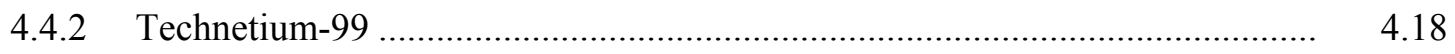

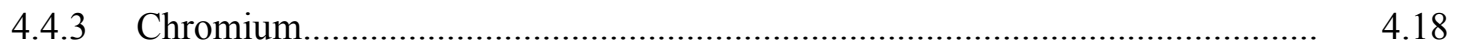

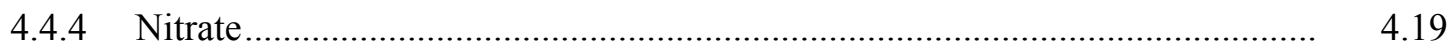

4.4.5 Percentage Leachable Contaminants of Interest............................................ 4.20

4.5 Contaminants of Interest in C-203 Residual Waste ................................................. 4.22

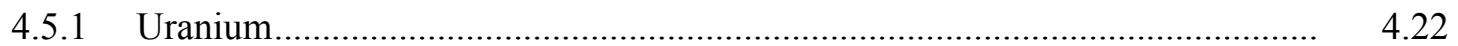

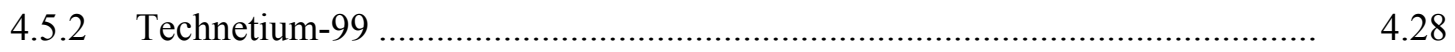

4.5.3 Chromium................................................................................. 4.29

4.5.4 Nitrate ..................................................................................... 4.32

4.5.5 Percentage Leachable Contaminants of Interest.............................................. 4.33

4.6 Contaminants of Interest in Residual Waste Saltcake ................................................. 4.34

5.0 Contaminant Release Mechanisms and Development of Release Models ............................ 5.1

5.1 Release Mechanisms ...................................................................................... 5.1

5.1.1 Mineral Dissolution.......................................................................... 5.1

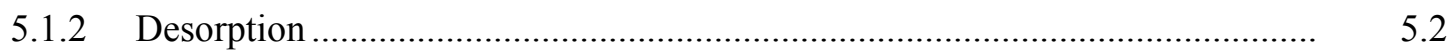

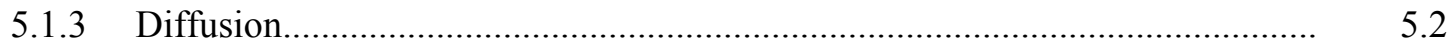

5.2 Geochemical Conditions Affecting Release ....................................................... 5.2

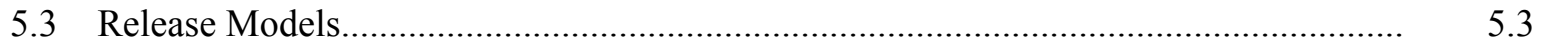

6.0 Contaminant Release Data for Residual Waste in Retrieved Tanks................................... 6.1

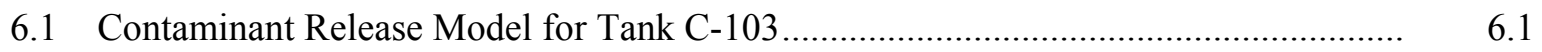

6.2 Contaminant Release Model for Tank C-106 ............................................................. 6.2

6.3 Contaminant Release Model for Tanks C-202 and C-203 ............................................ 6.3

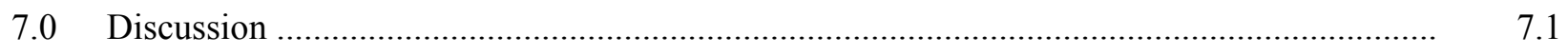

7.1 Improved Testing Methodologies for Residual Waste ............................................... 7.1

7.2 Improved Simulation of Long-Term Tank Environment ..........................................

7.3 Occurrence and Release of Technetium-99 from Residual Waste ............................... 7.2 
7.4 Presence and Impact of Organic Complexants on Contaminant Mobility in Residual Tank Waste.

7.5 Data Uncertainty...

\section{Figures}

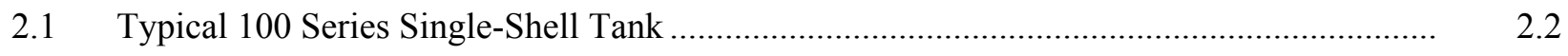

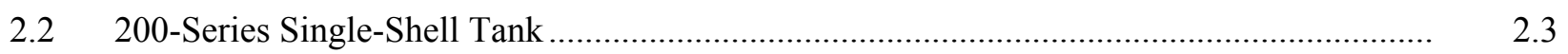

2.3 Metals Concentrations in Tank C-103 Residual Waste....................................................... 2.5

2.4 Metals Concentrations in Tank C-106 Residual Waste.................................................... 2.7

2.5 Tank C-106 Residual Waste Composition ..................................................................... 2.9

2.6 Metals Concentrations in Tank C-202 Residual Waste...................................................... 2.10

2.7 Tank C-202 Residual Waste Composition ............................................................................ 2.12

2.8 Metals Concentrations in Tank C-203 Residual Waste......................................................... 2.12

2.9 Tank C-203 Residual Waste Composition ........................................................................ 2.14

2.10 Low- and High- Magnification Backscattered Electron SEM Micrographs of Typical Solids Present in Unleached C-103 Residual Waste ............................................................ 2.18

2.11 Backscattered Electron SEM Micrographs of Typical Iron Oxide/Hydroxide Solids Present in C-103 Residual Waste

2.12 Backscattered Electron SEM Micrographs Showing the Ca Carbonate and Ca-Al Silicate Phases Identified in the 1-Month Single-Contact $\mathrm{Ca}(\mathrm{OH})_{2}$-Leached Samples of C-103 Residual Waste.

2.13 Low-Magnification Backscattered Electron SEM Micrographs of Particles Present in the Unleached Tank C-106 Residual Waste.

2.14 Backscattered Electron SEM Micrographs for Unleached, 1-Month Single-Contact Double Deionized Water Extraction-Leached, 1-Month Single-Contact $\mathrm{Ca}(\mathrm{OH})_{2}$-Leached, and 1-Month Single-Contact $\mathrm{CaCO}_{3}$-Leached Residual Waste from Tank C-202 .

2.15 Backscattered Electron Micrographs Showing Porous Uranium-Containing Solid as a Coating and Intergrowth with Iron Oxide in 1-Month Single-Contact Double Deionized Water Extraction-Leached Solid from C-202 Residual Waste.

2.16 Backscattered Electron SEM Micrographs of Unleached and Sequential Double Deionized Water-Leached Samples of C-203 Residual Waste from Sample 19887.

2.17 Particle of U-Na-C-O-P $\pm \mathrm{H}$ in the Unleached Sample of C-203 Residual Waste Showing Hexagonal, Rod-Like Dissolution Cavities

2.18 Secondary and Backscattered Electron Micrographs of Unleached C-103 Residual Waste...

2.19 Backscattered Electron Micrograph and Multi-Element EDS Map for Aggregate of $\mathrm{U}-\mathrm{Na}-\mathrm{C}-\mathrm{O}-\mathrm{P} \pm \mathrm{H}$ and Iron Oxide Particles Present in Sequential-Leached Water Extraction Sample of C-203 Residual Waste...

2.20 Backscattered Electron SEM Image and Multi-Element EDS Maps for a Particle Aggregate from the HF Extract of Tank C-106 Residual Waste.... 
2.21 Backscattered Electron SEM Micrographs Showing Iron Oxide Coating on a Particle Conglomerate Observed in the Long-Term Leached Water Extraction Sample of C-204

Pre-Retrieval Tank Waste.

2.22 Backscattered Electron SEM Micrographs Showing Iron Oxides with Preferential Dissolution Cavities and Possibly Casts Formed from Entrapped Gas Bubbles.

2.23 Typical EDS Spectra for Iron Oxide Particles Identified in C-202 Residual Waste from the 1-Month Single-Contact Leached Water Extraction

3.1 Dominant Aqueous Species of Uranium in the Absence of Dissolved Phosphate

3.2 Dominant Aqueous Species of Uranium in the Presence of Dissolved Phosphate

3.3 Stability Fields of Uranium Minerals in the Absence of Phosphate and Silica

3.4 Stability Fields of Uranium Minerals in the Presence of Phosphate

3.5 Concentration Plots Showing the Effect of Dissolved Carbonate and Calcium Concentrations of Solubility Controls for U(VI) at Selected Values of $\mathrm{pH}$ and Dissolved Sodium

3.6 Dominant Aqueous Species of Technetium

3.7 Dominant Aqueous Species of Technetium and Eh-pH Region Where the Solubility of Solid Amorphous $\mathrm{TcO}_{2} \cdot 2 \mathrm{H}_{2} \mathrm{O}$ Has Been Exceeded..

3.8 Dominant Aqueous Species of Iodine

3.9 Eh-pH Diagram Showing Dominant Aqueous Species of Chromium

3.10 Eh-pH Diagram Showing the Stability Field of Amorphous $\mathrm{Cr}(\mathrm{OH})_{3}$ 


\section{Tables}

2.1 Physical Properties of Residual Tank Waste ...................................................................... 2.4

2.2 Summary of Average Concentrations for Tank C-103 Residual Waste.............................. 2.6

2.3 Dominant Elemental Concentrations in C-103 Residual Waste............................................ 2.6

2.4 Summary of Average Concentrations for Tank C-106 Residual Waste............................... 2.8

2.5 Summary of Average Concentrations for Tank C-202 Residual Waste................................ 2.11

2.6 Summary of Average Concentrations for Tank C-203 Residual Waste............................... 2.13

2.7 Summary of Phases Indicated by SEM/EDS and XRD Results for Unleached and Leached Samples of C-103 Residual Waste

2.8 Summary of XRD and SEM/EDS Characterization Results for C-106 Residual Waste Compared to Those for Tank C-106 Waste Treated with Oxalic Acid ............................... 2.21

2.9 Comparison of XRD and SEM/EDS Results for the Unleached Samples of C-106 Residual Waste to the Results for the $\mathrm{Ca}(\mathrm{OH})_{2}$ - and $\mathrm{CaCO}_{3}$-Leached Samples of C-106 Residual Waste

2.10 Summary of XRD and SEM/EDS Characterization Results for C-202 and C-203 Residual Wastes

3.1 Concentrations of Dissolved COIs and Other Potentially Important Cationic and Anionic Constituents Used to Calculate the Eh-pH Diagrams......

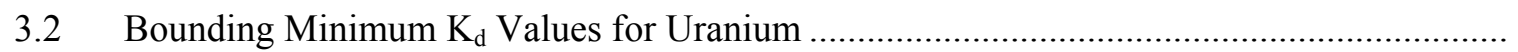

3.3 Bounding Minimum $\mathrm{K}_{\mathrm{d}}$ Values for Technetium .............................................................. 3.20

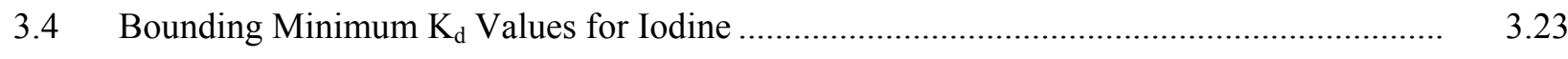

4.1 Tank C-103 Leach Test Results for Uranium.....................................................................

4.2 Tank C-103 Leach Test Results for Technetium-99 ........................................................

4.3 C-103 Leach Test Results for Chromium ........................................................................

4.4 C-103 Leach Test Results for Nitrate ..........................................................................

4.5 Percentages of Technetium-99 and Uranium-238 Released During Leaching Tests from Tank C-103 Residual Waste Relative to Acid Digestion Results......................................... 4.7

4.6 C-106 Residual Waste Leach Test Results for Uranium ....................................................

4.7 C-106 Leach Test Results for Technetium ...................................................................... 4.10

4.8 C-106 Leach Test Results for Iodine-129........................................................................ 4.10

4.9 C-106 Leach Test Results for Chromium........................................................................ 4.12

4.10 C-106 Leach Test Results for Nitrate ............................................................................. 4.13

4.11 Percentages of Technetium-99, Uranium-238, and Iodine-129 Released During Leaching Tests from Tank C-106 Residual Waste Relative to Fusion Results......................................

4.12 C-202 Leach Test Results for Uranium ......................................................................

4.13 Calculated Saturation Indices for Uranium Phases in Tank C-202 DDI Water Extractions.

4.14 Calculated Saturation Indices for Uranium Phases in Tank C-202 Ca..............................

4.15 Calculated Saturation Indices for Uranium Phases in Tank C-202 $\mathrm{CaCO}_{3}$ Extractions......... $\quad 4.17$

4.16 C-202 Technetium Leach Test Results........................................................................ 4.19 
4.17 C-202 Chromium Leach Test Results ............................................................................

4.18 C-202 Nitrate Leach Test Results...................................................................................... 4.21

4.19 Percentages of Technetium-99 and Uranium-238 Released During Leaching Tests from Tank C-202 Residual Waste Relative to Fusion Results ...................................................... 4.21

4.20 C-203 Leach Test Results for Uranium ...........................................................................

4.21 Calculated Saturation Indices for Significant Phases in Tank C-203 Water Extractions ....... 4.24

4.22 Calculated Saturation Indices for Significant Phases in Tank C-203

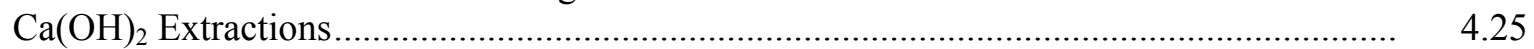

4.23 Calculated Saturation Indices for Significant Phases in Tank C-203 $\mathrm{CaCO}_{3}$ Extractions ..... $\quad 4.26$

$4.24 \mathrm{Na}_{2} \mathrm{U}_{2} \mathrm{O}_{7}(\mathrm{am})$ Saturation Indices for C-203 Solubility Experiments ...................................... 4.27

4.25 C-203 Leach Test Results for Technetium-99 ................................................................ 4.29

4.26 C-203 Leach Test Results for Chromium ...................................................................... 4.29

4.27 Molar Ratios of Chromium/Iron in Multiple Extractions and for C-202 and C-203 Post-

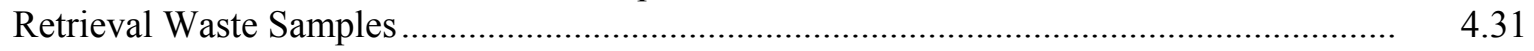

4.28 C-203 Leach Test Results for Nitrate ............................................................................... 4.33

4.29 Percentages of Technetium-99 and Uranium-238 Released During Leaching Tests from Tank C-203 Residual Waste Relative to Fusion Results ........................................................

6.1 Maximum C-103 Residual Waste and Contaminant Release Concentrations for Release

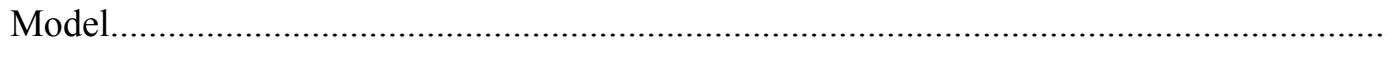

6.2 Summary of Contaminant Release Model Data for Tank C-106, Scenario 1 and Phase 2 of

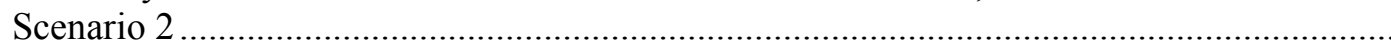

6.3 Summary of Contaminant Release Model Data for Tank C-106, Fresh Cement ...................

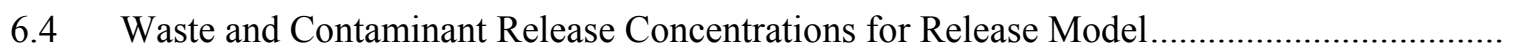

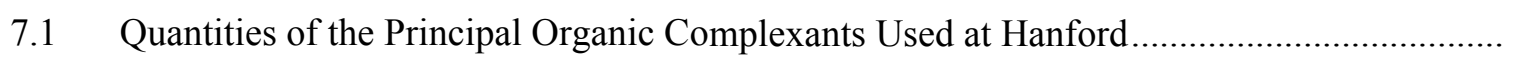




\subsection{Introduction}

The Hanford Federal Facility Agreement and Consent Order (Ecology et al. 1989) Milestone M-045-55 requires that a Resource Conservation and Recovery Act (RCRA) Facility Investigation (RFI) report be submitted to the Washington State Department of Ecology. The RFI report will provide a detailed description of the state of knowledge needed for tank farm performance assessments. Appendix D of the RFI report discusses contaminant release from residual waste in closed single-shell tanks (SSTs) and other waste forms associated with these tanks. The following data package provides the detailed technical information about contaminant release from closed SSTs to support the RFI report. It was prepared by Pacific Northwest National Laboratory (PNNL) for CH2M HILL Hanford Group, Inc. (CH2M HILL), which is tasked by the U.S. Department of Energy (DOE) with tank closure.

It is not technically feasible to remove all of the waste material from the underground Hanford SSTs that will remain in place after closure of the tank farms. However, DOE is bound by the Tri-Party Agreement (HFFACO, Ecology et al. 1989) with the Washington State Department of Ecology and the U.S. Environmental Protection Agency (EPA) to retrieve at least $99 \%$ of the waste or as much as can be retrieved with available technology. As of November 2007, DOE has successfully retrieved waste from seven tanks (C-103, C-106, C-201, C-202, C-203, C-204, and S-112). The amount of waste left in the tanks would form a layer only $1 \mathrm{in}$. thick on the bottom of the tanks if spread uniformly over the area of the tank bottom. This residual waste represents a potential source of contamination to the environment if the contaminants were to migrate out of a tank in the future. The future mobility of contaminants in the residual waste will be considered in performance assessments conducted on the closed tanks.

Typical Hanford SSTs contain both saltcake waste and sludge; the primary difference between the two waste forms is the large concentrations of readily soluble salts (primarily $\mathrm{NaNO}_{3}$ and $\mathrm{NaNO}_{2}$ ) in the saltcake compared to the solids in sludge. A specific tank is designated a saltcake or sludge tank based on the predominance of one type of waste over the other under pre-retrieval conditions. Contaminant release studies to date have focused on residual waste from sludge tanks, such as those in the C Tank Farm, although a brief discussion of contaminant release from saltcake tank residual waste may be found in Section 4.6 of this report.

To evaluate the potential future release of contaminants from the closed tanks, testing of the residual waste has been conducted to understand its composition, solid-phase characteristics, and the water leachability of contaminants of interest from the solids. The leaching tests have been conducted under the geochemical conditions expected to exist in the closed tanks over the extended time frame (thousands of years) of the performance assessment. At this time, characterization and testing of residual waste has been completed on four retrieved tanks (C-103, C-106, C-202, and C-203). This data package focuses on the residual waste for these four tanks and the contaminant release models developed by testing these wastes. In addition, this data package contains general information on the expected closed tank geochemical conditions that might affect contaminant mobility and specific information on the geochemistry of the contaminants of interest under the long-term closed tank conditions. Detailed contaminant release testing has not been conducted on residual waste from retrieved tanks C-201 and C-204 because it is believed that the residual material in these tanks is similar to that of tested tanks C-202 and C-203. Limited testing of residual waste from tank S-112 is currently being conducted. 
Contaminant release from Hanford waste and engineered waste forms has been estimated using mathematical models and various levels of data for many years as part of site and performance assessments. An initial data catalog of release models was prepared by Riley and Lopresti (2001) and was subsequently updated in 2003 and 2006 (Riley and Lopresti 2003; Riley et al. 2006). In addition to providing descriptions of a number of mathematical models, such as a soil-debris model, solubility model, cement model, and glass model, these documents provide references to data sources for the various models. The release model for residual tank waste in the latest data compilation (Riley et al. 2006) was recommended to be the cement model in which release is controlled by diffusion of contaminants out of the cement matrix. The cement model was chosen by Riley et al. (2006) as a best option pending the development of new models based on the work described in this data package and associated contaminant release model and supporting data reports by Deutsch and coworkers at PNNL. The following PNNL reports on contaminant release from waste in the SSTs have been published or are in preparation:

- Deutsch WJ, KM Krupka, KJ Cantrell, CF Brown, MJ Lindberg, HT Schaef, SM Heald, BW Arey, RK Kukkadapu. 2005. Advances in Geochemical Testing of Key Contaminants in Residual Hanford Tank Waste. PNNL-15372, Pacific Northwest National Laboratory, Richland, Washington.

- Deutsch WJ, KM Krupka, MJ Lindberg, KJ Cantrell, CF Brown, and HT Schaef. 2006. Hanford Tank 241-C-106: Impact of Cement Reactions on Release of Contaminants from Residual Waste. PNNL-15544, Pacific Northwest National Laboratory, Richland, Washington.

- Deutsch WJ, KM Krupka, MJ Lindberg, KJ Cantrell, CF Brown, and HT Schaef. 2007a. Hanford Tank 241-C-106: Residual Waste Contaminant Release Model and Supporting Data. PNNL-15187, Rev. 1, Pacific Northwest National Laboratory, Richland, Washington.

- Deutsch WJ, KM Krupka, MJ Lindberg, KJ Cantrell, CF Brown, and HT Schaef. 2007b. Hanford Tanks 241-C-203 and 241-C-204: Residual Waste Contaminant Release Model and Supporting Data. PNNL-14903 Rev. 1, Pacific Northwest National Laboratory, Richland, Washington.

- Deutsch WJ, KM Krupka, MJ Lindberg, KJ Cantrell, CF Brown, SV Mattigod, HT Schaef, and BW Arey. 2007c. Hanford Tanks 241-C-202 and 241-C-203: Residual Waste Contaminant Release Model and Supporting Data. PNNL-16229, Pacific Northwest National Laboratory, Richland, Washington.

- Cantrell KJ, KM Krupka, MJ Lindberg, KN Geiszler, BW Arey, HT Schaef, and CF Brown. 2007a. Hanford Tank 241-C-103 Residual Waste Contaminant Release Models and Supporting Data Report. PNNL-16738, Pacific Northwest National Laboratory, Richland, Washington.

Additional publications and presentations that have been written based on the work of the PNNL Residual Tank Waste Contaminant Release Project include

- Lindberg MJ and WJ Deutsch. 2003. Tank 241-AY-102 Data Report. PNNL-14344, Pacific Northwest National Laboratory, Richland, Washington.

- Krupka KM, WJ Deutsch, MJ Lindberg, KJ Cantrell, NJ Hess, HT Schaef, and BW Arey. 2004. Hanford Tanks 241-AY-102 and 241-BX-101: Sludge Composition and Contaminant Release Data. PNNL-14614, Pacific Northwest National Laboratory, Richland, Washington. 
- Arey BW, HT Schaef, KM Krupka, and WJ Deutsch. 2005. "Application of Scanning Electron Microscopy to Characterization of Radioactive Solid Waste from Underground Storage Tanks" (extended abstract and poster). Presented to Microscopy and Microanalysis 2005, Honolulu, Hawaii, July 31-August 4, 2005.

- Brown CF, KN Geiszler, and T Vickerman. 2005. "Extraction and Quantitative Analysis of Iodine in Solid and Solution Matrices." Analytical Chemistry 77:7062-7066.

- Krupka KM, HT Schaef, BW Arey, SM Heald, WJ Deutsch, MJ Lindberg, and KJ Cantrell. 2006. "Residual Waste from Hanford Tanks 241-C-203 and 241-C-204. 1. Solids Characterization." Environmental Science and Technology 40(12):3749-3754.

- Cantrell KJ, KM Krupka, WJ Deutsch, and MJ Lindberg. 2006. "Residual Waste from Hanford Tanks 241-C-203 and 241-C-204. 2. Contaminant Release and Modeling." Environmental Science and Technology 40(12):3755-3761.

- Krupka KM, WJ Deutsch, HT Schaef, BW Arey, SM Heald, MJ Lindberg, and KJ Cantrell. 2006. "Characterization of Solids in Residual Wastes from Underground Storage Tanks at the Hanford Site, Washington, U.S.A.” In Scientific Basis for Nuclear Waste Management XXX, DS Dunn, C Poinssot, and B Begg (eds), pp. 473-482. Symposium Proceedings Volume 985, Materials Research Society, Warrendale, Pennsylvania.

Other sources of information on the composition of waste in the SSTs include the Best Basis Inventory $^{(a)}(\mathrm{BBI})$, Retrieval Data Reports (RDRs), and the Hanford Tank Waste Operations Simulator (HTWOS) model. The BBI of single-shell tank contents is based on historical and current knowledge of transfers into and out of the tanks, process information, and waste sampling, including residual waste at the end of final waste retrieval from each tank. The composition of the residual waste from each tank is published in an RDR that also provides information on tank-specific waste retrieval methodology, sampling and analysis of residual waste, and the volume of residual waste. Examples of the RDRs include Parker (2006a: tank C-106), Parker (2006b: tank C-202), and Parker (2006c: tank C-203). The HTWOS model (Kirkbride et al. 2005) uses the BBI to define the initial inventory in each tank and provide estimates of annual waste movement from Hanford single- and double-shell tanks to its final disposition, including tank residuals, all secondary waste streams (gaseous, liquid, and solid), tank retrieval losses, high-level waste glass, low-activity waste glass, bulk vitrification glass, and contacthandled and remote-handled transuranic waste.

The information in this data package is current as of November 29, 2007. This document is arranged in six major sections following this introduction. Section 2 describes the single-shell Hanford tanks and the residual waste characterized from the four tanks C-103, C-106, C-202, and C-203. Section 3 discusses the selection of the contaminants of interest and their geochemistry in closed tanks. Section 4 describes the testing of the residual waste samples to develop contaminant release data and presents the results of the leaching tests. Section 5 provides a discussion of contaminant release mechanisms from residual waste, geochemical conditions in the tank that affect release, and the types of release models and scenarios. Section 6 is a summary of recommended release model data for tanks C-103, C-106, C-202, and C-203. Section 7 provides a discussion of data uncertainty and improved testing methods to enhance the release models. Section 8 is the reference list.

(a) The Best Basis Inventory is reported in the Tank Waste Information System (TWINS) Internet site that can be found at http://twins.pnl.gov/twins.htm. 


\subsection{Hanford Single-Shell Tanks and Residual Waste Characteristics}

This section provides a general physical description of the SSTs used for waste storage at Hanford and specific information on the physical properties, chemical composition, and solid phases of the residual waste in the four tanks (C-103, C-106, C-202, and C-203) for which contaminant release data have been developed.

\subsection{Single-Shell Tank Description}

There are 177 large, underground waste storage tanks located at the Hanford Site; 149 of them are single-shelled. These SSTs and their associated facilities are grouped into 12 farms - six farms (S, SX, T, TX, TY, and U) in the 200 West Area and six farms (A, AX, B, BX, BY, and C) in the 200 East Area.

There are two series of SSTs, based mainly on size - the large 100-Series tanks and the much smaller 200 -Series tanks. Three generations of 100-Series tanks of varying sizes $(500,000$ to 1 million gal) were constructed from 1943 to 1964, and all incorporated common design elements such as carbon-steel liners and cylindrical reinforced concrete structures as shown in Figure 2.1. For all designs of SSTs, the carbon steel liners covered the interior bottom and sides of the reinforced concrete cylindrical shell but did not cover the domed top of each of the 100-Series tanks. All the 100-Series SST domes were designed and constructed with an internal exposed bare concrete surface. Also, depending on the volume of the tank, the steel liners varied in height from 18 to $32 \mathrm{ft}$, with specific tank diameters varying from 20 to $75 \mathrm{ft}$. To shield personnel from radiation, all SST domes remain covered with a minimum of $7 \mathrm{ft}$ of soil (Anderson 1990).

The 200-Series tanks have a diameter of $20 \mathrm{ft}$ and a waste volume capacity of 55,000 gal. The wastes in the 200-Series tanks are typical of tanks designed for a specific process that required less tank volume than the 100-Series tanks, which were used mainly for storage. The number of risers ${ }^{(a)}$ and riser diameters (see Figure 2.2) are less than those required to operate the 100-Series tanks. This limits the options for waste retrieval operations in the 200-Series tanks to smaller available retrieval machinery configurations (Anderson 1990).

The HFFACO (Ecology et al. 1989, Milestone M-45) requires retrieval of "as much tank waste as technically possible, with tank waste residues not to exceed $360 \mathrm{ft}^{3}$ (2,690 gal) in each of the 100 Series tanks, $30 \mathrm{ft}^{3}$ (224 gal) in each of the 200 Series tanks, or the limit of waste retrieval technology capability, whichever is less." A waiver process to be implemented on a tank-by-tank basis has been established in Appendix H of HFFACO.

The emptied tanks will have to be filled with some material to prevent their collapse. This material may also serve to immobilize tank waste residues or to lessen the release rates of contaminants from the residues.

(a) Risers are connectors between the top of the underground tank and the land surface that allow access to the tank. 


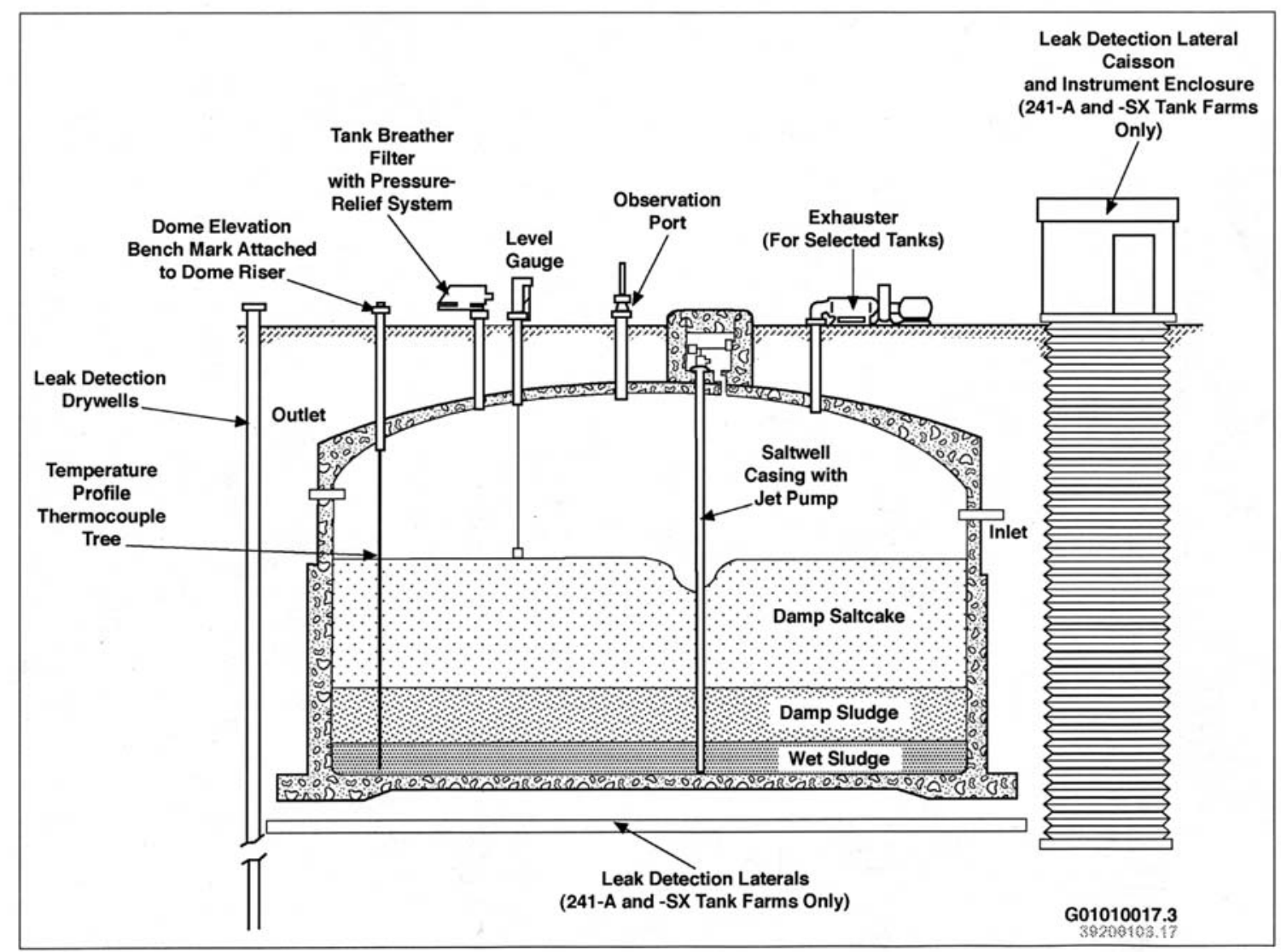

Figure 2.1. Typical 100 Series Single-Shell Tank

\subsection{Tank Waste Characteristics}

Characterization studies have been conducted on residual waste that will remain in single-shell underground waste tanks after closure. The objective of these studies was to produce data that can be used to develop source release models for contaminants of interest that are relevant to long-term performance assessment models. At the time of publication of this report, contaminant release models have been developed for retrieved tanks C-103, C-106, C-202, and C-203.

\subsubsection{Physical Properties}

Physical properties of residual tank waste needed for performance assessment modeling include volume, moisture content, and density of the residual waste. This information for tanks C-103, C-106, C-202, and C-203 was obtained from the Tank Waste Information Network System (TWINS) and is presented in Table 2.1. The residual waste volume includes material in the bottom of the tank (solids and liquids), in equipment in the tank, on the stiffener rings, and on the tank wall. The moisture content data were determined using differential scanning calorimetry/thermogravimetric analysis. 


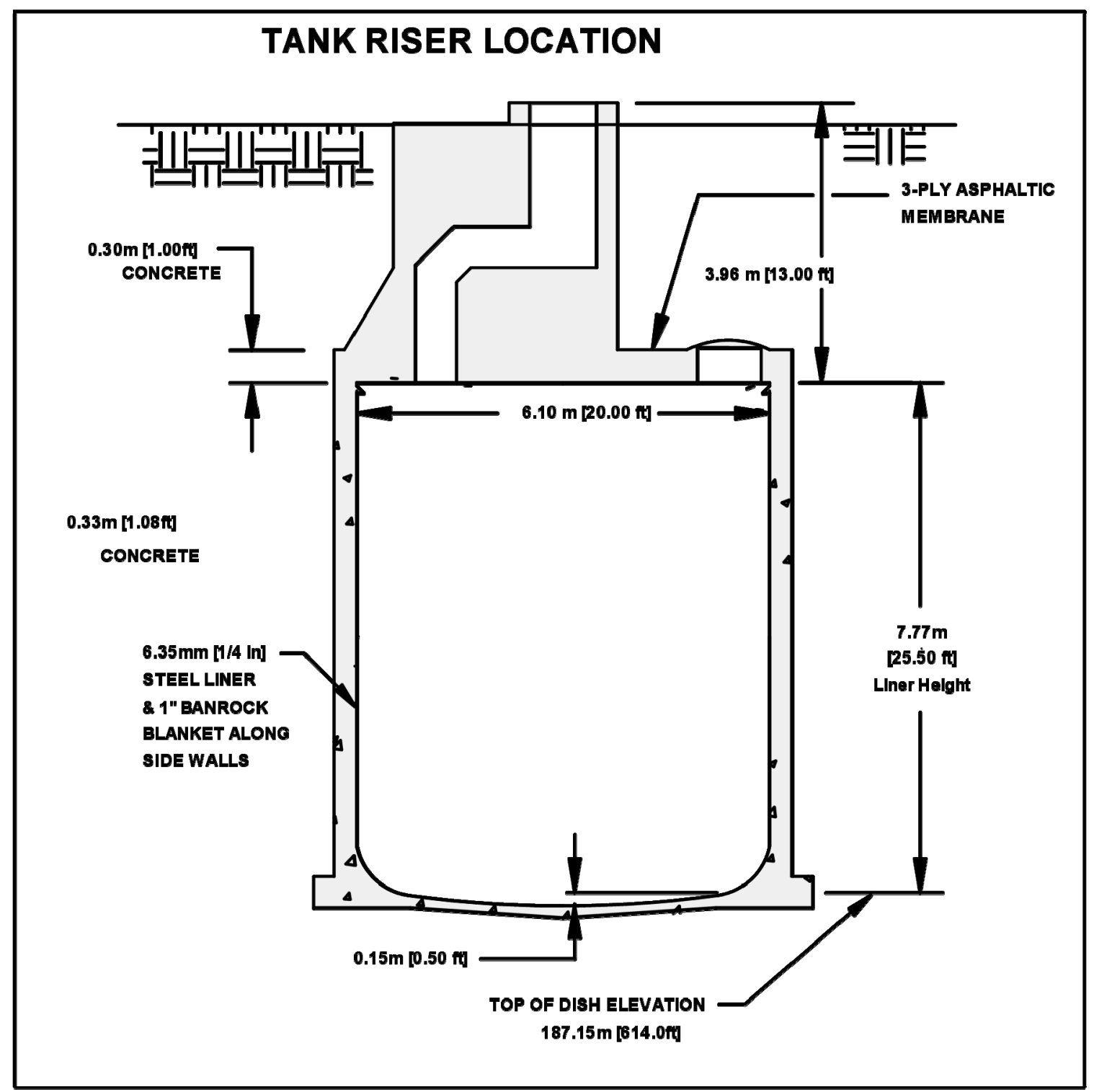

Figure 2.2. 200-Series Single-Shell Tank

\subsubsection{Chemical Composition}

The chemical composition of the residual waste in each tank was measured by PNNL on samples of the material collected after final waste retrieval. The results of these measurements on samples provided by CH2M HILL to PNNL are included in this section. Additional chemical composition data for residual waste measured by the Hanford Site contractor laboratory (the 222-S Laboratory) are available in TWINS. Note that final retrieval processes can significantly alter the compositions of the final residual waste left in the tanks by selectively removing certain waste components from the pre-retrieval tank sludge. A variety of retrieval processes was used for the different tanks. Waste from tank C-103 was retrieved using a modified sluicing retrieval system consisting of two sluicers and a slurry pump. Supernatant from double-shell tank (DST) 241-AN-106 (AN-106) was used as the sluicing fluid to mobilize the solids. For tank C-106, final retrieval was achieved using a $0.9 \mathrm{M}$ oxalic acid solution to dissolve and suspend the solids, which were then pumped out as much as possible. Several additions and 
Table 2.1. Physical Properties of Residual Tank Waste (from Tank Waste Information Network System [TWINS])

\begin{tabular}{|c|c|c|c|c|c|}
\hline Tank ID & $\begin{array}{c}\text { Residual Waste } \\
\text { Volume }\left(\mathrm{ft}^{3}\right)\end{array}$ & Sample ID & $\begin{array}{c}\text { Moisture } \\
\text { Content (\%) }\end{array}$ & Sample ID & $\begin{array}{c}\text { Bulk Density } \\
(\mathrm{g} / \mathrm{mL})\end{array}$ \\
\hline \multirow{4}{*}{ C-103 } & \multirow{4}{*}{338} & S06T007130 & 5.48 & $\begin{array}{l}\text { S06T007124 } \\
\end{array}$ & 1.39 \\
\hline & & S06T007130 & 4.16 & S06T007124 & 1.36 \\
\hline & & S06T007146 & 8.95 & S06T007140 & 1.61 \\
\hline & & S06T007161 & 13.3 & S06T007155 & 1.84 \\
\hline \multirow{4}{*}{ C-106 } & \multirow{4}{*}{359} & S04T000116 & 47.1 & S04T000120 & 1.58 \\
\hline & & S04T000121 & 45.6 & S04T000107 & 1.58 \\
\hline & & S04T000103 & 42.4 & S04T000107 & 1.53 \\
\hline & & S04T000108 & 32.8 & & \\
\hline \multirow{2}{*}{ C-202 } & \multirow{2}{*}{19.7} & S05T001064 & 22.5 & S05T001056 & 1.77 \\
\hline & & S05T001065 & 27.3 & S05T001057 & 1.72 \\
\hline \multirow{9}{*}{ C-203 } & \multirow{9}{*}{18.5} & $\begin{array}{l}\text { S95T000807 } \\
\end{array}$ & 38.0 & $\begin{array}{l}\text { S95T000802 } \\
\end{array}$ & 1.51 \\
\hline & & S95T000811 & 31.4 & S95T000798 & 1.72 \\
\hline & & S02T001017 & 41.7 & & \\
\hline & & S03T001774 & 32.9 & & \\
\hline & & S03T001837 & 19.2 & & \\
\hline & & S05T000328 & 35.2 & & \\
\hline & & S05T000338 & 36.2 & & \\
\hline & & S03T001847 & 31.2 & & \\
\hline & & S03T001853 & 22.7 & & \\
\hline
\end{tabular}

removals of the oxalic acid solution were required to remove the desired quantity of sludge. After the final removal, the sludge was rinsed with water to remove as much of the oxalic acid solution as possible. A $0.5 \mathrm{M} \mathrm{NaOH}$ solution was then added to neutralize the residual waste, and then removed. Retrieval from tanks C-202 and C-203 was conducted using a vacuum system to remove as much sludge as possible. A high-pressure water spray was used with the vacuum to break up the larger particles of waste that could not be removed solely by vacuum suction because of their size.

As part of the characterization work, various single-contact and periodic replenishment extraction tests were conducted on the residual waste using various solutions. Note that in this document, reference is made to unleached samples, which specifically refer to the as-received residual waste samples that have not been contacted with any of these extraction solutions.

\subsubsection{Chemical Composition: C-103}

The major compositional features of the $\mathrm{C}-103$ residual waste are discussed in this section. Detailed chemical composition data for residual waste from tank C-103 are presented in Cantrell et al. (2007a). Figure 2.3 shows the average concentrations of the major metals in the $\mathrm{C}-103$ residual waste based on acid digestion analyses of three samples $(19845,19849$, and 19850). The metals present in highest concentrations in the samples with their maximum values in units of micrograms/gram $(\mu \mathrm{g} / \mathrm{g}[\mathrm{ppm}])$ are aluminum $\left(1.55 \times 10^{5}\right)$, iron $\left(1.68 \times 10^{4}\right)$, sodium $\left(8.53 \times 10^{3}\right)$, silicon $\left(9.89 \times 10^{3}\right)$, and uranium $\left(4.18 \times 10^{3}\right)$. In general, the metals concentrations for the three samples were quite similar. 


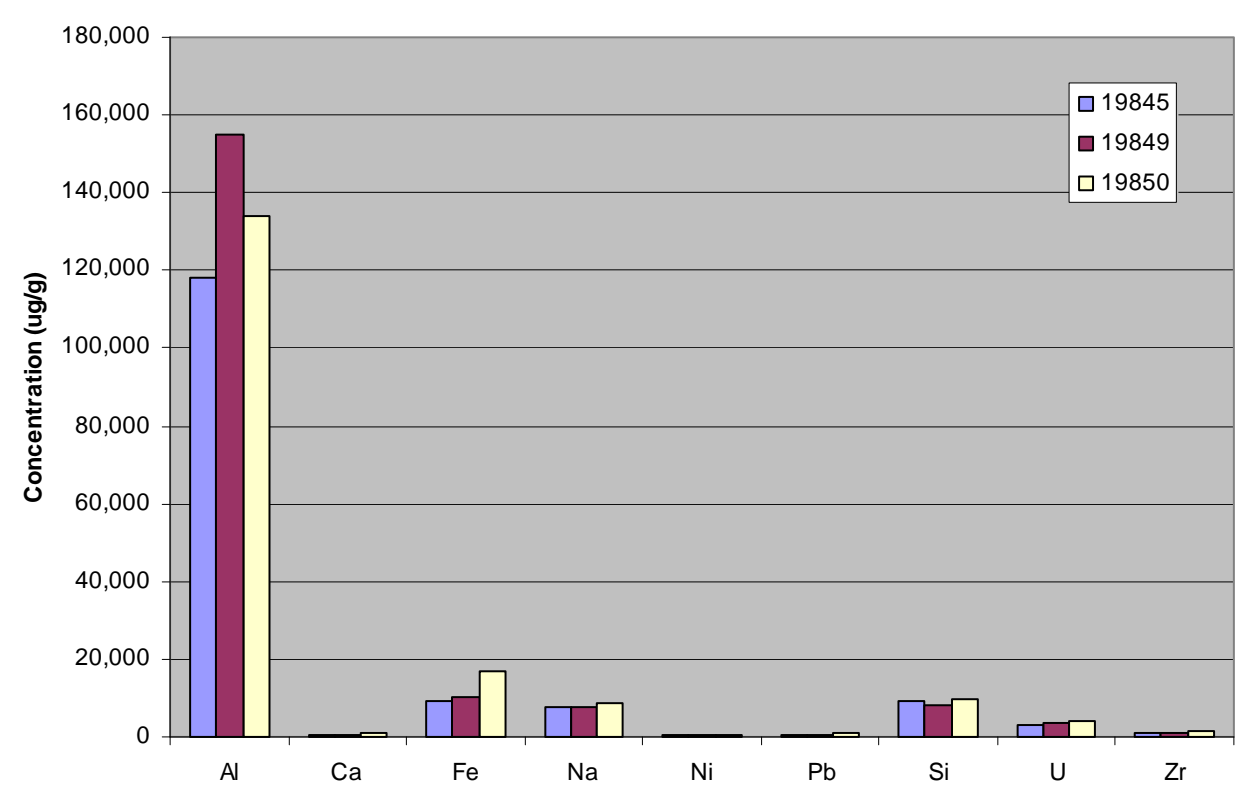

Figure 2.3. Metals Concentrations in Tank C-103 Residual Waste $(\mu \mathrm{g} / \mathrm{g}$, dry weight basis). Sample numbers are indicated in the legend (from Cantrell et al. 2007a).

Table 2.2 provides a summary of the average concentrations of the major components and contaminants of interest (COIs) for the three C-103 residual waste samples. Metals were determined in the asreceived residual waste using a microwave-assisted acid digestion procedure. Anions were determined from the total concentrations of the periodic replenishment water leaching tests. A detailed description of the leaching tests for C-103 residual waste may be found in Cantrell et al. (2007a). It should be noted that anion quantification by these leaching tests may be not be complete if an anionic constituent, such as phosphate, is present in insoluble minerals.

Concentrations listed in parentheses in Table 2.2 and all subsequent tables in this data package are defined as less than the estimated quantitation limit (EQL) ${ }^{(a)}$ but greater than a zero instrument signal. These values are reported for informational purposes only. They may reflect actual concentrations that are real but have larger associated uncertainties than values above the EQL, or they may reflect values that were calculated from the instrument's background signal and are not representative of actual waste composition. Concentrations listed as less-than $(<)$ values in the tables refer to a zero instrument measurement. In these instances, the reported analyte concentration is assigned a value of " $<\mathrm{EQL}$ " using the EQL value appropriate for that particular analyte and set of analytical conditions.

Table 2.3 shows the major components of the tank C-103 residual waste that were measured at concentrations greater than $1,000 \mu \mathrm{g} / \mathrm{g}$ in terms of weight percentage. The predominant metals with average concentrations are aluminum (13.6 wt $\%)$, iron (1.2 wt \%), sodium $(0.78 \mathrm{wt} \%)$, silicon $(0.91 \mathrm{wt} \%)$, and uranium $(0.37 \mathrm{wt} \%)$.

(a) The EQL of an element is determined by analyzing a suite of continuing calibration verification (CCV) standards at the beginning and end of each analytical run. The lowest CCV standard that is within $\pm 10 \%$ of its certified value is multiplied by the dilution factor for the sample to determine the EQL for the element for the particular analytical run. The EQL may vary with each analysis, depending on sample matrix, dilution factors, and instrument performance. 
Table 2.2. Summary of Average Concentrations for Tank C-103 Residual Waste (from Cantrell et al. 2007a)

\begin{tabular}{|c|c|}
\hline Analyte & Concentration $(\mu \mathrm{g} / \mathrm{g}$ dry wt. \\
\hline $\mathrm{Al}$ & 136,000 \\
\hline $\mathrm{Ba}$ & 181 \\
\hline $\mathrm{Ca}$ & 616 \\
\hline $\mathrm{Cr}$ & 193 \\
\hline $\mathrm{Fe}$ & 12,000 \\
\hline $\mathrm{K}$ & BDL \\
\hline $\mathrm{Mg}$ & $(42)$ \\
\hline $\mathrm{Mn}$ & 470 \\
\hline $\mathrm{Na}$ & 7,840 \\
\hline $\mathrm{Ni}$ & 420 \\
\hline $\mathrm{Pb}$ & 892 \\
\hline $\mathrm{Si}$ & 9,070 \\
\hline $\mathrm{Sr}$ & 90.7 \\
\hline${ }^{238} \mathrm{U}$ & 3,730 \\
\hline${ }^{239} \mathrm{Pu}$ & 8.02 \\
\hline${ }^{237} \mathrm{~Np}$ & 1.30 \\
\hline${ }^{241} \mathrm{Am}$ & 0.053 \\
\hline${ }^{99} \mathrm{Tc}$ & 0.231 \\
\hline${ }^{129} \mathrm{I}$ & $\left(1.11 \times 10^{-5}\right)$ \\
\hline \multicolumn{2}{|r|}{ Water Leach } \\
\hline $\mathrm{F}^{-}$ & $(31)$ \\
\hline $\mathrm{Cl}^{-}$ & (5.4) \\
\hline $\mathrm{NO}_{2}^{-}$ & $(59)$ \\
\hline $\mathrm{NO}_{3}^{-}$ & $(250)$ \\
\hline $\mathrm{CO}_{3}{ }^{2-}$ & BDL \\
\hline $\mathrm{SO}_{4}{ }^{2-}$ & BDL \\
\hline $\mathrm{PO}_{4}{ }^{3-}$ & $(66)$ \\
\hline
\end{tabular}

Table 2.3. Dominant Elemental Concentrations in C-103 Residual Waste (from Cantrell et al. 2007a)

\begin{tabular}{||c|c|c|c||}
\hline \multirow{2}{*}{ Element } & 19845 & 19849 & 19850 \\
\cline { 2 - 4 } & \multicolumn{3}{|c|}{ Weight \% Dry Basis } \\
\hline \hline $\mathrm{Al}$ & 11.8 & 15.5 & 13.4 \\
\hline $\mathrm{Fe}$ & 0.90 & 1.03 & 1.68 \\
\hline $\mathrm{Na}$ & 0.76 & 0.74 & 0.85 \\
\hline $\mathrm{Si}$ & 0.90 & 0.84 & 0.99 \\
\hline $\mathrm{U}$ & 0.33 & 0.37 & 0.42 \\
\hline
\end{tabular}


The Hanford 222-S Laboratory also conducted extensive characterization of the residual waste samples collected from tank C-103. Results of these analyses are reported in the TWINS database. Concentration determined by the 222-S Laboratory are generally similar to those in Cantrell et al. (2007a) for most analytical methods (including inductively coupled plasma-mass spectrometry [ICP-MS], ion chromatography [IC], alpha energy analysis [AEA], gamma energy analysis, technetium-99, and percentage water). The differences in the measured concentrations for selected analytes between those reported by the 222-S Laboratory and Cantrell et al. (2007a) may be due to a variety of factors, primarily sample heterogeneity and the use of different extraction/digestion techniques by the two laboratories. See Cantrell et al. (2007a) for more details.

\subsubsection{Chemical Composition: C-106}

The major compositional features of the C-106 residual waste are discussed in this section. Detailed chemical composition data for residual waste from tank C-106 are presented in Deutsch et al. (2007a). Figure 2.4 shows the concentrations of the major metals in the waste, based on fusion and acid digestion analyses of primary and duplicate samples. The metals present in highest concentrations in the samples with their maximum values in units of micrograms per gram $(\mu \mathrm{g} / \mathrm{g}[\mathrm{ppm}])$ are aluminum $\left(1.49 \times 10^{5}\right)$, manganese $\left(1.23 \times 10^{5}\right)$, sodium $\left(6.17 \times 10^{4}\right)$, Fe $\left(4.7 \times 10^{4}\right)$, and calcium $\left(3.95 \times 10^{4}\right)$. For these metals, there is some variability in concentrations between the fusion method and the EPA acid digestion technique. The fusion method generally gave higher concentrations of the major metals by $10 \%$ to $40 \%$ compared to the concentrations measured by the EPA Method 3050B acid digestion (EPA 1996).

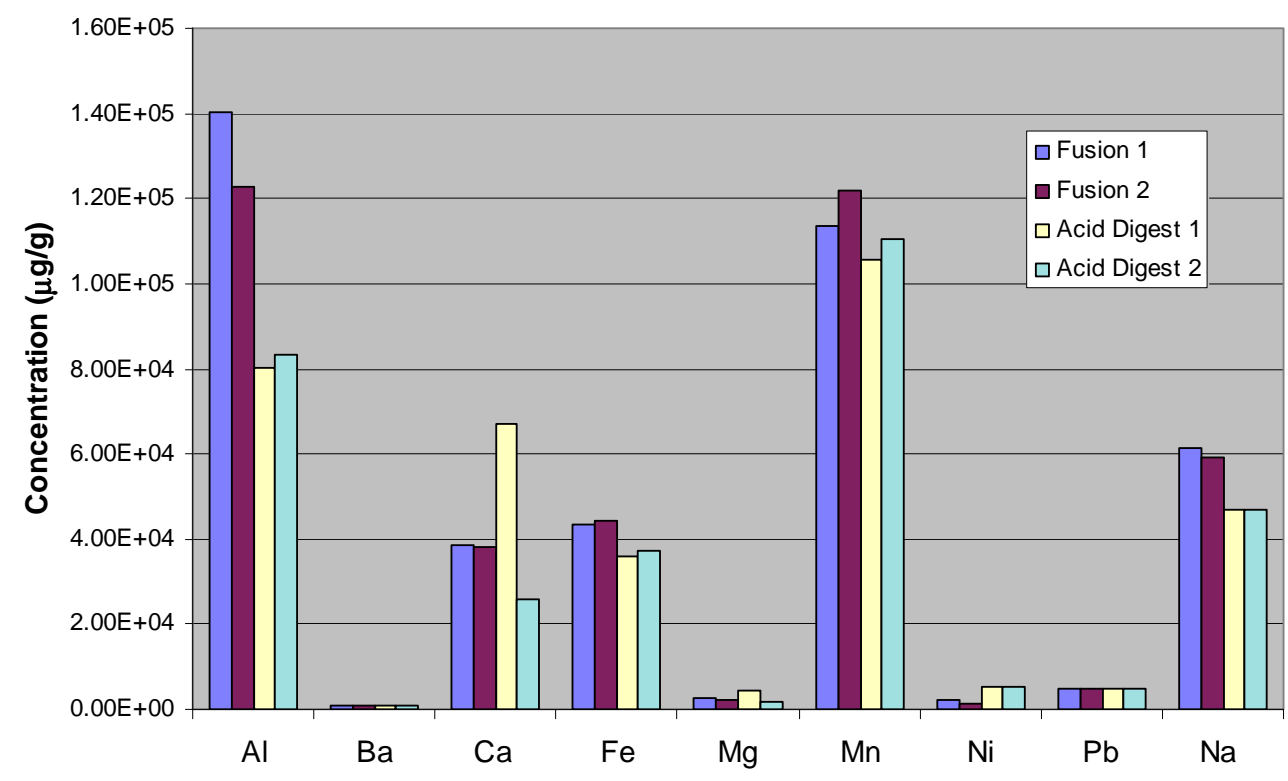

Figure 2.4. Metals Concentrations in Tank C-106 Residual Waste ( $\mu \mathrm{g} / \mathrm{g}$, dry weight basis) (from Deutsch et al. 2007a)

Table 2.4 provides a summary of the concentrations of the major components and COIs in tank C-106 residual waste. Metals were measured by fusion and acid digestion analysis. Anions were determined from the total concentrations of the periodic replenishment water leaching tests. The average result for $\mathrm{NO}_{3}{ }^{-}$was determined from the sum of concentrations in sequential water extracts. A detailed description of the leaching tests for C-106 residual waste may be found in Deutsch et al. (2006, 2007a). It should be 
Table 2.4. Summary of Average Concentrations for Tank C-106 Residual Waste (from Deutsch et al. 2007a)

\begin{tabular}{|c|c|c|}
\hline \multirow[b]{2}{*}{ Analyte } & \multicolumn{2}{|c|}{ C-106 ( $\mu \mathrm{g} / \mathrm{g}$ dry wt.) } \\
\hline & Fusion & $\begin{array}{l}\text { EPA Acid } \\
\text { Digestion }\end{array}$ \\
\hline $\mathrm{Al}$ & 131,483 & 81,699 \\
\hline $\mathrm{Ba}$ & 1,028 & 914 \\
\hline $\mathrm{Ca}$ & 38,221 & 46,490 \\
\hline $\mathrm{Cr}$ & $(896)$ & $(727)$ \\
\hline $\mathrm{Fe}$ & 43,777 & 36,663 \\
\hline $\mathrm{K}$ & $\mathrm{N} / \mathrm{A}$ & 8,526 \\
\hline $\mathrm{Mg}$ & 2,485 & 3,162 \\
\hline $\mathrm{Mn}$ & 117,767 & 108,069 \\
\hline $\mathrm{Na}$ & 60,400 & 46,720 \\
\hline $\mathrm{Ni}$ & 1,712 & 5,373 \\
\hline $\mathrm{Pb}$ & 4,841 & 4,814 \\
\hline $\mathrm{Si}$ & $(19,086)$ & $(4,895)$ \\
\hline $\mathrm{Sr}$ & $(256)$ & $(493)$ \\
\hline${ }^{238} \mathrm{U}$ & 247 & 310 \\
\hline${ }^{239} \mathrm{Pu}$ & 29.8 & 27.7 \\
\hline${ }^{237} \mathrm{~Np}$ & 9.27 & 9.04 \\
\hline${ }^{241} \mathrm{Am}$ & 1.83 & 2.05 \\
\hline${ }^{99} \mathrm{Tc}$ & 1.16 & 1.14 \\
\hline${ }^{129} \mathrm{I}$ & 0.673 & NA \\
\hline \multicolumn{3}{|c|}{ Water Leach } \\
\hline $\mathrm{F}^{-}$ & \multicolumn{2}{|c|}{33} \\
\hline Formate & \multicolumn{2}{|c|}{$<65$} \\
\hline $\mathrm{Cl}^{-}$ & \multicolumn{2}{|c|}{87} \\
\hline $\mathrm{NO}_{2}^{-}$ & \multicolumn{2}{|c|}{$<73$} \\
\hline $\mathrm{NO}_{3}^{-}$ & \multicolumn{2}{|c|}{$<70$} \\
\hline $\mathrm{CO}_{3}{ }^{2-}$ & \multicolumn{2}{|c|}{39,500} \\
\hline $\mathrm{SO}_{4}{ }^{2-}$ & \multicolumn{2}{|c|}{$<66$} \\
\hline Oxalate & \multicolumn{2}{|c|}{63,900} \\
\hline $\mathrm{PO}_{4}^{3-}$ & \multicolumn{2}{|c|}{$<91$} \\
\hline
\end{tabular}

noted that anion quantification by these leaching tests may be not be complete if the anion is present in insoluble minerals, such as phosphates. Note that the oxalate likely came from the retrieval process and was not a primary constituent of the waste.

Figure 2.5 shows the major components of the tank C-106 residual waste that were measured at concentrations greater than $1,000 \mu \mathrm{g} / \mathrm{g}$ in terms of weight percentage. The metal results in Figure 2.5 are those determined by fusion. The predominant metals are aluminum $(13.1 \mathrm{wt} \%)$, manganese $(11.8 \mathrm{wt} \%)$, sodium $(6.0 \mathrm{wt} \%)$, and iron $(4.4 \mathrm{wt} \%)$. The predominant anions are oxalate $(6.4 \mathrm{wt} \%)$ and carbonate $(4.0 \mathrm{wt} \%)$. 


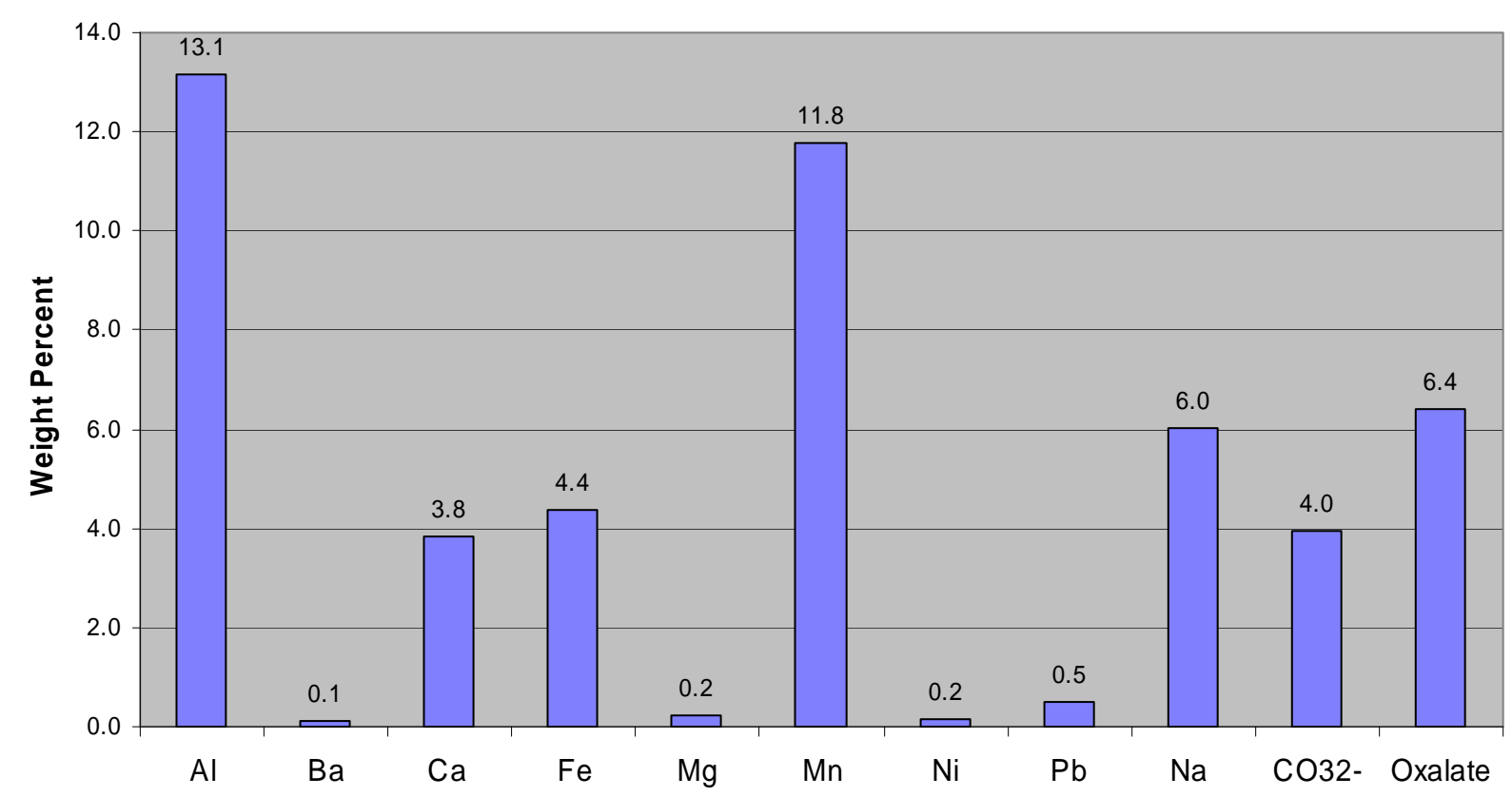

Figure 2.5. Tank C-106 Residual Waste Composition (dry weight basis) (from Deutsch et al. 2007a)

The Hanford 222-S Laboratory also conducted extensive characterization of the residual waste samples collected from tank C-106. Results of these analyses are reported in the Analytical Results for Tank 241-C-106 Solid Clam Shell Samples Supporting Closure Action (McKinney 2004). Concentration results reported in McKinney (2004) are similar to those in Deutsch et al. (2007a) for most analytical methods (including ICP-MS, IC, AEA, gamma energy analysis, technetium-99, and percentage water). Differences were observed for some analyses/analytes (inductively coupled plasma-optical emission spectroscopy [ICP-OES] and iodine-129). The differences in the measured concentrations for selected analytes between those reported by McKinney (2004) and Deutsch et al. (2007a) are due to a variety of factors, primarily sample heterogeneity and the use of different extraction/digestion techniques by the two laboratories. See the original report for more details (Deutsch et al. 2007a).

\subsubsection{Chemical Composition: C-202}

The major compositional features of tank C-202 residual waste are discussed in this section. Detailed characterization results for residual waste from tank C-202 are presented in Deutsch et al. (2007c).

Figure 2.6 shows the concentration results (primary and duplicate analyses) of the major metals in the residual waste, based on fusion and acid digestion analyses. The fusion and acid digestion results are more similar for C-202 (and C-203) samples than they were for C-106 samples because a more aggressive acid digestion method (EPA Method 3052) was used on the C-202/203 samples than was used on the $\mathrm{C}-106$ samples. Sodium from the fusion results is not reported because sodium bisulfite is used in the fused sample dissolution process. The elements present in highest concentrations in the C-202 residual waste samples with their maximum values in units of micrograms per gram $(\mu \mathrm{g} / \mathrm{g})$ dry weight are uranium $\left(2.52 \times 10^{5}\right)$, iron $\left(1.26 \times 10^{5}\right)$, sodium $\left(7.00 \times 10^{4}\right)$, manganese $\left(2.72 \times 10^{4}\right)$, chromium $\left(1.41 \times 10^{4}\right)$, and aluminum $\left(1.68 \times 10^{4}\right)$. Except for silicon and nickel, results for the fusion method and the EPA acid digestion technique are quite comparable. It is believed that the acid digestions provide more reliable results for these two elements. In the case of silicon, the acid digestions are more effective due to the use of hydrofluoric acid in the acid mixture. 


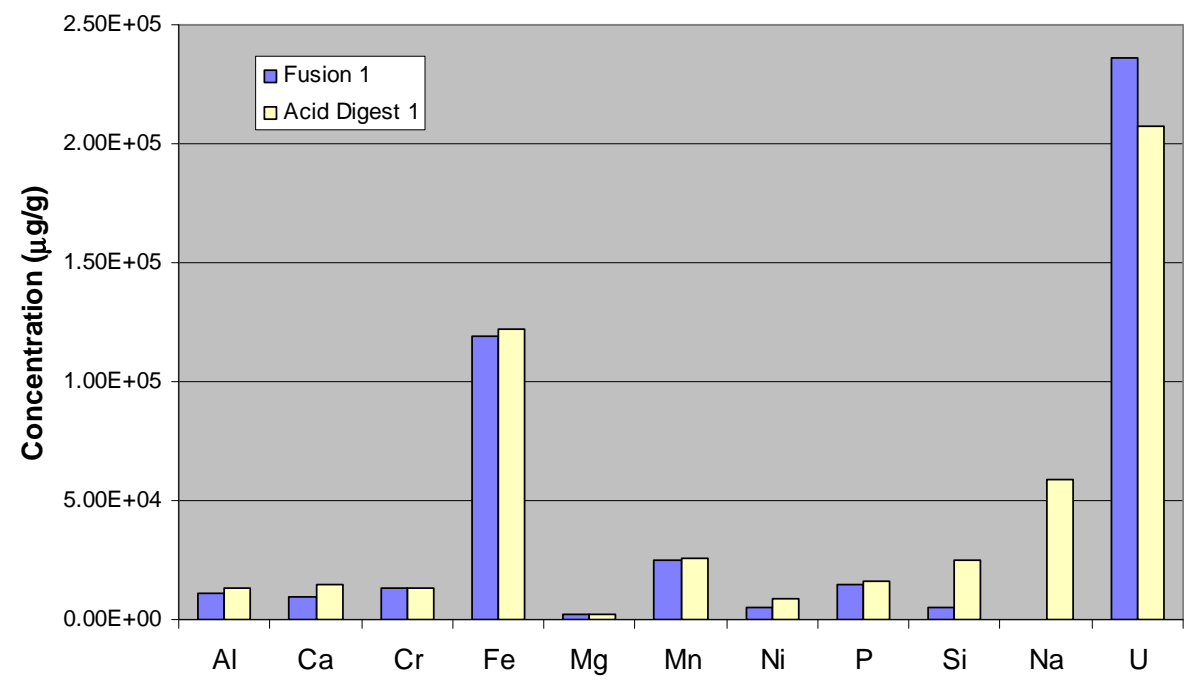

Figure 2.6. Metals Concentrations in Tank C-202 Residual Waste (dry weight basis) (from Deutsch et al. 2007c)

Table 2.5 provides a summary of the major components and COIs for residual C-202 waste (Deutsch et al. 2007c). Metals were determined by fusion and acid digestion analysis. Anion analyses were calculated from the sum of concentrations measured in the periodic replenishment water leaching tests. For chromium, technetium-99, and uranium-238, the fusion results and the acid digestion results are comparable. For plutonium-239, neptunium-237, and, to a lesser degree, americium-241, the acid digestion results are significantly higher than those of the fusion method. The reasons for the discrepancies have not been identified.

Figure 2.7 shows the major components (in weight percentage) of the tank C-202 residual waste that were measured at concentrations greater than $0.3 \%(3,000 \mu \mathrm{g} / \mathrm{g})$ (Deutsch et al. 2007c). The metals results shown in Figure 2.7 were those determined by fusion. The predominant metals are uranium (23.6 wt \%), iron (11.9 wt\%), sodium (5.9 wt\%), manganese (2.6 wt \%), chromium (1.3 wt\%), aluminum $(1.1 \mathrm{wt} \%)$, and calcium $(1.0 \mathrm{wt} \%)$. The predominant anions are oxalate $(3.2 \mathrm{wt} \%)$, phosphate $(1.7 \mathrm{wt} \%)$, carbonate $(1.2 \mathrm{wt} \%)$, fluoride $(0.6 \mathrm{wt} \%)$, and nitrate $(0.4 \mathrm{wt} \%)$.

\subsubsection{Chemical Composition: C-203}

The major composition features reported by Deutsch et al. (2007c) for tank C-203 residual waste are discussed in this section. Detailed characterization results for residual waste from tank C-203 are presented in Deutsch et al. (2007c). Figure 2.8 shows the concentration results of the major metals in the waste, based on fusion and acid digestion analyses for primary and duplicate samples. Sodium from the fusion results is not reported because sodium bisulfite is used in the fused sample dissolution process. The elements present in highest concentrations in the samples with their maximum values in units of micrograms per gram $(\mu \mathrm{g} / \mathrm{g})$ are uranium $\left(6.49 \times 10^{5}\right)$, sodium $\left(9.77 \times 10^{4}\right)$, phosphorus $\left(5.21 \times 10^{4}\right)$, iron $\left(2.19 \times 10^{4}\right)$, and chromium $\left(9.14 \times 10^{3}\right)$. Except for silicon, results for the fusion method and the EPA acid digestion technique are comparable. It is believed that the acid digestions provide more reliable results for this element. Acid digestions are more effective at quantifying silicon because of the use of hydrofluoric acid (HF) in the acid mixture. 
Table 2.5. Summary of Average Concentrations for Tank C-202 Residual Waste (from Deutsch et al. 2007c)

\begin{tabular}{|c|c|c|}
\hline \multirow[b]{2}{*}{ Analyte } & \multicolumn{2}{|c|}{ C-202 ( $\mu \mathrm{g} / \mathrm{g}$ dry wt.) } \\
\hline & Fusion & $\begin{array}{l}\text { EPA Acid } \\
\text { Digestion }\end{array}$ \\
\hline$\overline{\mathrm{Al}}$ & 1011,300 & 13,600 \\
\hline $\mathrm{Ba}$ & $(13)$ & 208 \\
\hline $\mathrm{Ca}$ & 9,610 & 14,500 \\
\hline $\mathrm{Cr}$ & 13,300 & 13,200 \\
\hline $\mathrm{Fe}$ & 119,000 & 122,000 \\
\hline $\mathrm{K}$ & $\mathrm{N} / \mathrm{A}$ & $<15,800$ \\
\hline $\mathrm{Mg}$ & 2,440 & 2,560 \\
\hline $\mathrm{Mn}$ & 25,100 & 25,700 \\
\hline $\mathrm{Na}$ & $\mathrm{N} / \mathrm{A}$ & 58,800 \\
\hline $\mathrm{Ni}$ & 5,430 & 9,070 \\
\hline $\mathrm{Pb}$ & (177) & 7,980 \\
\hline $\mathrm{Si}$ & 5,840 & 25,000 \\
\hline $\mathrm{Sr}$ & 1,160 & 1,510 \\
\hline${ }^{238} \mathrm{U}$ & 236,000 & 207,000 \\
\hline${ }^{239} \mathrm{Pu}$ & 55.9 & 435 \\
\hline${ }^{237} \mathrm{~Np}$ & 0.361 & 2.16 \\
\hline${ }^{241} \mathrm{Am}$ & 0.233 & 0.449 \\
\hline${ }^{99} \mathrm{Tc}$ & 0.231 & 0.149 \\
\hline${ }^{129} \mathrm{I}$ & $<4.1$ & NA \\
\hline \multicolumn{3}{|c|}{ Water Leach } \\
\hline $\mathrm{F}^{-}$ & \multicolumn{2}{|c|}{6,030} \\
\hline $\mathrm{Cl}^{-}$ & \multicolumn{2}{|c|}{161} \\
\hline $\mathrm{NO}_{2}^{-}$ & \multicolumn{2}{|c|}{485} \\
\hline $\mathrm{NO}_{3}^{-}$ & \multicolumn{2}{|c|}{3,540} \\
\hline $\mathrm{CO}_{3}{ }^{2-}$ & \multicolumn{2}{|c|}{12,200} \\
\hline $\mathrm{SO}_{4}{ }^{2-}$ & \multicolumn{2}{|c|}{334} \\
\hline Oxalate & \multicolumn{2}{|c|}{32,400} \\
\hline $\mathrm{PO}_{4}^{3-}$ & \multicolumn{2}{|c|}{17,700} \\
\hline \multicolumn{3}{|c|}{ EPA = U.S. Environmental Protection Agenc } \\
\hline
\end{tabular}

Table 2.6 provides a summary of the major components and COIs reported in Deutsch et al. (2007c) for tank C-203 residual waste. Metals were measured by fusion and acid digestion analysis. Anions were determined from the sum of the periodic replenishment water leaching tests. The fusion results and the acid digestion results are quite comparable. For plutonium-239 and americium-241, the acid digestion results are significantly higher than those of the fusion method. The reasons for the discrepancies have not been identified. Figure 2.9 shows the major components of the tank C-203 waste that were measured at concentrations greater than $1,000 \mu \mathrm{g} / \mathrm{g}$ in terms of weight percentage (Deutsch et al. 2007c). The results for metals shown in Figure 2.9 are those determined by fusion. The predominant metal concentrations in dry weight percent are uranium (58.6 wt\%), sodium $(9.6 \mathrm{wt} \%)$, iron (1.0 wt $\%)$, and chromium $(0.6 \mathrm{wt} \%)$. The predominant anion concentrations in dry weight percent are carbonate $(5.0 \mathrm{wt} \%)$, phosphate $(4.3 \mathrm{wt} \%)$, nitrate $(0.5 \mathrm{wt} \%)$, and fluoride $(0.3 \mathrm{wt} \%)$. 


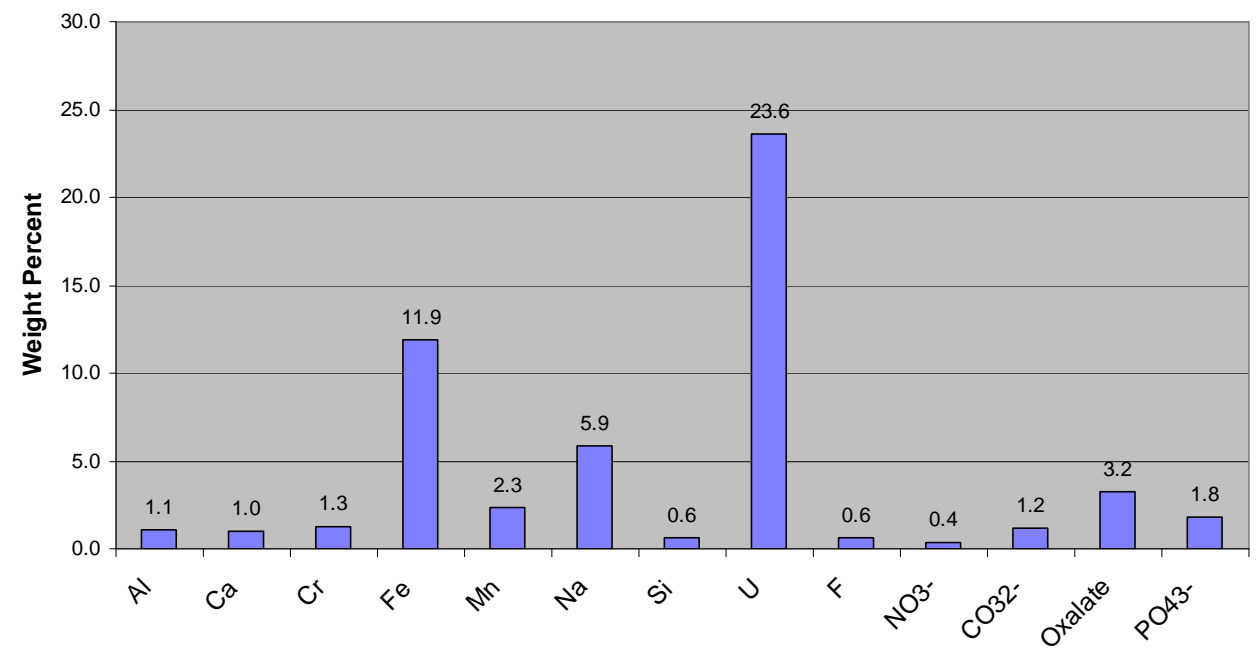

Figure 2.7. Tank C-202 Residual Waste Composition (dry weight basis) (from Deutsch et al. 2007c)

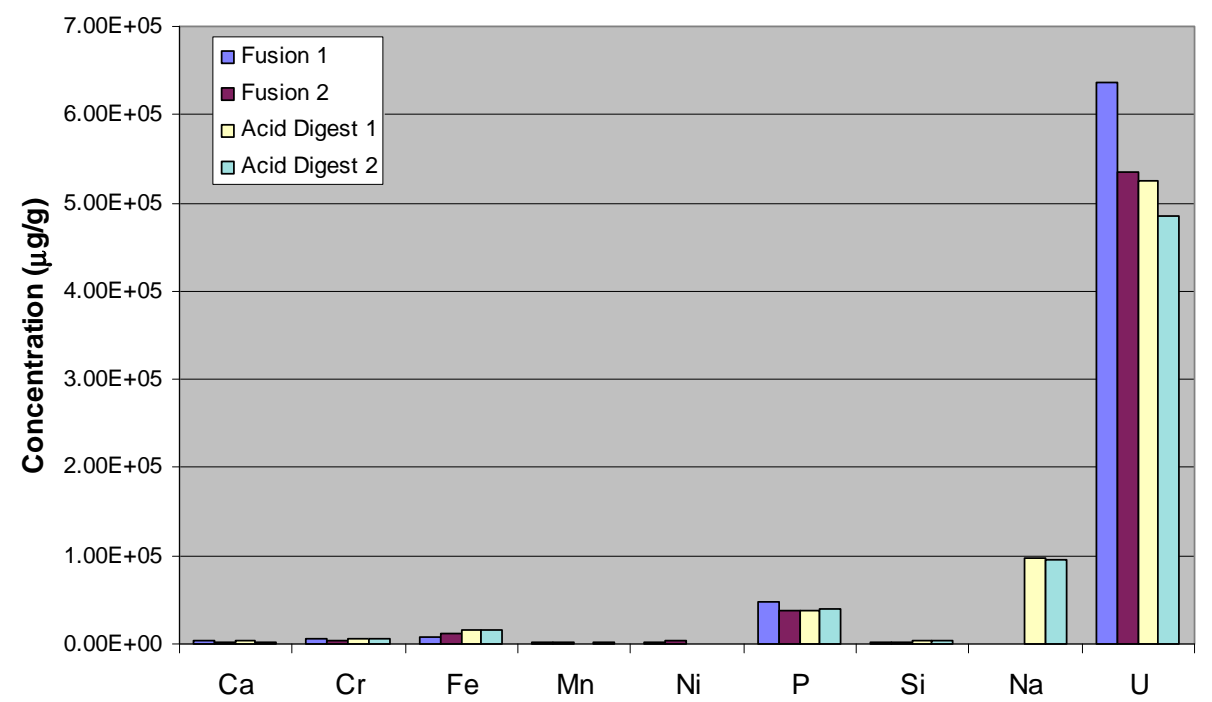

Figure 2.8. Metals Concentrations in Tank C-203 Residual Waste (dry weight basis) (from Deutsch et al. 2007c) 
Table 2.6. Summary of Average Concentrations for Tank C-203 Residual Waste (from Deutsch et al. 2007c)

\begin{tabular}{|c|c|c|}
\hline \multirow[b]{2}{*}{ Analyte } & \multicolumn{2}{|c|}{ C-203 ( $\mu \mathrm{g} / \mathrm{g}$ dry wt.) } \\
\hline & Fusion & $\begin{array}{l}\text { EPA Acid } \\
\text { Digestion }\end{array}$ \\
\hline$\overline{\mathrm{Al}}$ & \begin{tabular}{c|}
$<216$ \\
\end{tabular} & $<><10$ \\
\hline $\mathrm{Ba}$ & $<43$ & $<142$ \\
\hline $\mathrm{Ca}$ & 2,750 & 3,140 \\
\hline $\mathrm{Cr}$ & 5,910 & 5,910 \\
\hline $\mathrm{Fe}$ & 9,830 & 16,300 \\
\hline $\mathrm{K}$ & $\mathrm{N} / \mathrm{A}$ & $<355,000$ \\
\hline $\mathrm{Mg}$ & 642 & $(729)$ \\
\hline $\mathrm{Mn}$ & 1,210 & 956 \\
\hline $\mathrm{Na}$ & N/A & 95,800 \\
\hline $\mathrm{Ni}$ & 2,440 & 510 \\
\hline $\mathrm{Pb}$ & 493 & 5,630 \\
\hline $\mathrm{Si}$ & 2,700 & 3,490 \\
\hline $\mathrm{Sr}$ & 344 & 409 \\
\hline${ }^{238} \mathrm{U}$ & 586,000 & 505,000 \\
\hline${ }^{239} \mathrm{Pu}$ & $(3.06)$ & 18.2 \\
\hline${ }^{237} \mathrm{~Np}$ & $(0.0565)$ & $(0.0519)$ \\
\hline${ }^{241} \mathrm{Am}$ & 0.00596 & 0.0140 \\
\hline${ }^{99} \mathrm{Tc}$ & 0.0807 & $(0.0947)$ \\
\hline${ }^{129} \mathrm{I}$ & $<3.8$ & NA \\
\hline \multicolumn{3}{|c|}{ Water Leach } \\
\hline $\mathrm{F}^{-}$ & \multicolumn{2}{|c|}{2,760} \\
\hline $\mathrm{Cl}^{-}$ & \multicolumn{2}{|c|}{201} \\
\hline $\mathrm{NO}_{2}^{-}$ & \multicolumn{2}{|c|}{610} \\
\hline $\mathrm{NO}_{3}^{-}$ & \multicolumn{2}{|c|}{4,840} \\
\hline $\mathrm{CO}_{3}^{2-}$ & \multicolumn{2}{|c|}{49,900} \\
\hline $\mathrm{SO}_{4}{ }^{2-}$ & \multicolumn{2}{|c|}{288} \\
\hline Oxalate & \multicolumn{2}{|c|}{1,500} \\
\hline $\mathrm{PO}_{4}^{3-}$ & \multicolumn{2}{|c|}{43,300} \\
\hline \multicolumn{3}{|c|}{ EPA = U.S. Environmental Protection Agenc } \\
\hline
\end{tabular}

\subsubsection{Tank Residual Waste Solid Phase Composition}

Contaminants present in tank residual waste occur as components of the solid phases and the solution phase that may be present. The majority of the contaminants are likely adsorbed onto or coprecipitated within the solid phases. Any contaminants currently in the solution phase will be transferred to the solid waste as the solution evaporates and solid phases precipitate from the oversaturated solution phase. This section describes the solid phases that have been identified in tank residual wastes that have been characterized to date from SSTs. 


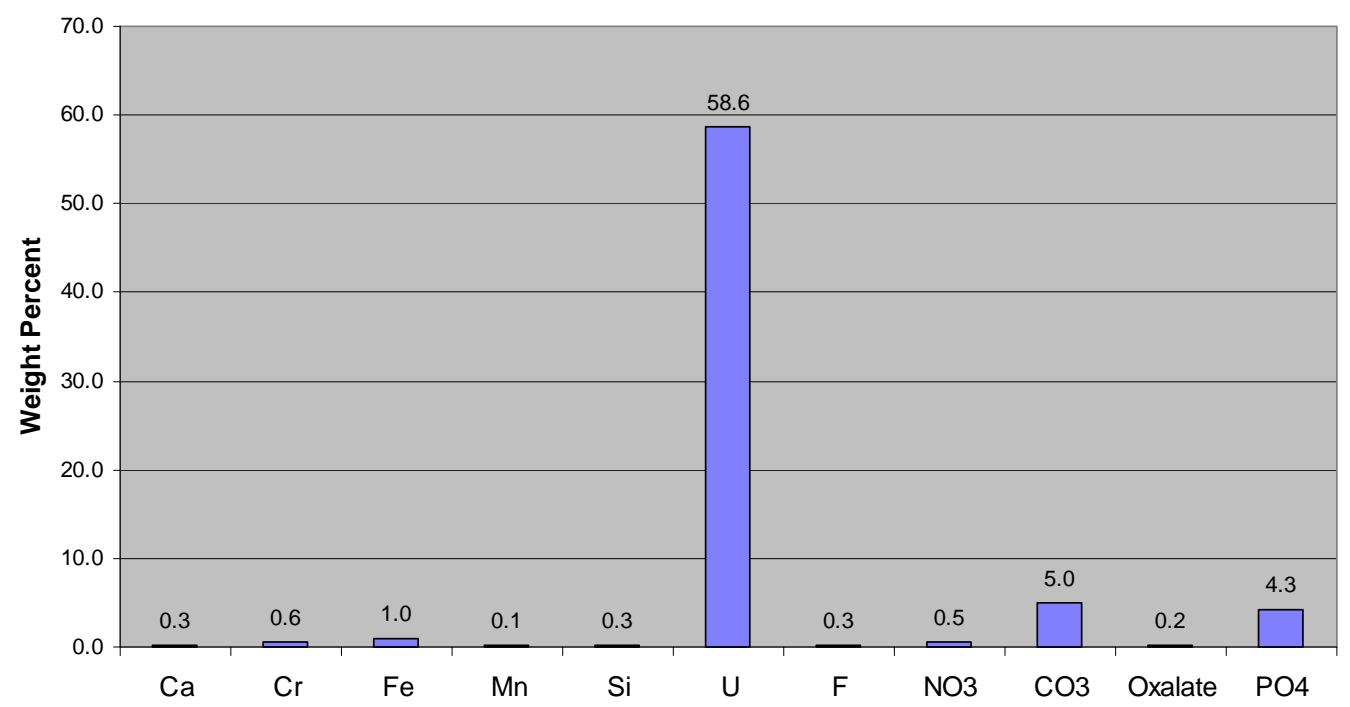

Figure 2.9. Tank C-203 Residual Waste Composition (dry weight basis) (from Deutsch et al. 2007c)

\subsubsection{Solid Phases: C-103}

Samples of unleached, 1-month single-contact DDI water-leached, 1-month single-contact $\mathrm{Ca}(\mathrm{OH})_{2}$ leached, and 1-month single-contact $\mathrm{CaCO}_{3}$-leached solids from samples 19845, 19849, and 19850 of C-103 residual waste were characterized by bulk x-ray diffraction (XRD) and scanning electron microscopy/energy-dispersive spectroscopy (SEM/EDS). The results of these analyses are described in detail in Cantrell et al. (2007a).

Table 2.7 provides a comparison of the phases identified by bulk XRD and SEM/EDS. The XRD results indicate that all of the unleached and leached C-103 samples contain predominantly (probably more than $\sim 90 \%$ or more) gibbsite $\left[\mathrm{Al}(\mathrm{OH})_{3}\right]$, which is consistent with what was observed by SEM analysis.

The XRD patterns for the leached samples also are consistent with the presence of hematite $\left(\alpha-\mathrm{Fe}_{2} \mathrm{O}_{3}\right)$ but at concentrations significantly lower than those of gibbsite in these samples. The presence of hematite likely corresponds to one or two possible iron oxide/hydroxide phases detected in the unleached and leached C-103 waste samples by SEM/EDS. Although hematite was not identified in the XRD patterns for unleached samples, hematite is likely present (as indicated by SEM/EDS results) in the unleached samples but at concentrations too low to be detected by XRD.

The XRD patterns for the $\mathrm{Ca}(\mathrm{OH})_{2}$-leached samples contain additional XRD reflections that are not present in the unleached, DDI water-leached, and $\mathrm{CaCO}_{3}$-leached samples. These remaining reflections are consistent with the major reflections in the database patterns for cancrinite [ $\left.\mathrm{Na}_{6} \mathrm{CaAl}_{6} \mathrm{Si}_{6}\left(\mathrm{CO}_{3}\right) \mathrm{O}_{24} \cdot 2 \mathrm{H}_{2} \mathrm{O}\right]$, calcite $\left(\mathrm{CaCO}_{3}\right)$, silica-free katoite $\left[\mathrm{Ca}_{2} \mathrm{Al}_{2}(\mathrm{OH})_{12}\right]$, calcium aluminum oxide carbonate hydrate $\left(\mathrm{Ca}_{4} \mathrm{Al}_{2} \mathrm{O}_{6} \mathrm{CO}_{3} \bullet 11 \mathrm{H}_{2} \mathrm{O}\right)$, and rabejacite $\left[\mathrm{Ca}\left(\mathrm{UO}_{2}\right)_{4}\left(\mathrm{SO}_{4}\right)_{2}(\mathrm{OH})_{6} \cdot 6 \mathrm{H}_{2} \mathrm{O}\right]$. The detection of cancrinite by XRD is consistent with its identification by crystal form and elemental composition by SEM/EDS analysis of the $\mathrm{Ca}(\mathrm{OH})_{2}$-leached samples as well as DDI water-leached and $\mathrm{CaCO}_{3}$-leached samples. 
Table 2.7. Summary of Phases Indicated by SEM/EDS and XRD Results for Unleached and Leached Samples of C-103 Residual Waste (from Cantrell et al. 2007a)

\begin{tabular}{|c|c|c|}
\hline $\begin{array}{l}\text { Compositions of Phases } \\
\text { Identified by SEM/EDS }\end{array}$ & Phases Identified by XRD & $\begin{array}{l}\text { Information Regarding Occurrence Based on } \\
\text { SEM/EDS Analyses }\end{array}$ \\
\hline \multicolumn{3}{|c|}{$\begin{array}{l}\text { Because } \mathrm{H} \text { is not detectable by EDS and } \mathrm{C} \text { was used for coating the SEM mounts, } \\
\text { all of the phases listed below as being identified by SEM/EDS also may contain } \mathrm{H} \text { and/or } \mathrm{C} \text {. }\end{array}$} \\
\hline \multicolumn{3}{|c|}{ Phases Thought To Be Present in All Unleached and Leached C-103 Residual Waste Samples } \\
\hline $\mathrm{Al}-\mathrm{O}$ & Gibbsite & $\begin{array}{l}\text { - Overwhelmingly the most dominant phase(s) in } \\
\text { all unleached and leached samples } \\
\text { - Possibly two phases, based on calculated EDS- } \\
\text { based compositions }\end{array}$ \\
\hline $\mathrm{Fe}-\mathrm{O}$ & Hematite & $\begin{array}{l}\text { - Second most common phase; present in all } \\
\text { unleached and leached samples } \\
\text { - Two Fe oxyhydroxides phases may be present, } \\
\text { based on morphology } \\
\text { - When } \mathrm{Cr}, \mathrm{Ni}, \mathrm{Pb} \text {, and } \mathrm{Mn} \text { are detected by EDS, } \\
\text { these metals always are associated with the } \mathrm{Fe} \\
\text { oxide phase } \\
\text { - A few wt\% U also may sometimes be associated } \\
\text { with some Fe oxide particles }\end{array}$ \\
\hline $\mathrm{Ag} \pm \mathrm{Hg}-\mathrm{O}$ & & $\begin{array}{l}\text { - Present in all unleached and leached samples } \\
\text { - May have two Ag phases-an Ag oxide (with no } \\
\text { detectable Hg) and an Ag-Hg oxide }\end{array}$ \\
\hline $\mathrm{U}-\mathrm{O}$ & & $\begin{array}{l}\text { - Most common U-containing particle } \\
\text { - Typically present as micrometer- or } \\
\text { submicrometer-sized particles }\end{array}$ \\
\hline $\mathrm{Na}-\mathrm{Ca}-\mathrm{Al}-\mathrm{Si}-\mathrm{O}$ & $\begin{array}{l}\text { Cancrinite - identified by } \\
\text { XRD only in the } \mathrm{Ca}(\mathrm{OH})_{2} \text { - } \\
\text { leached sample } 19845\end{array}$ & $\begin{array}{l}\text { - Probably a silicate } \\
\text { - Morphology similar to "balls of twine," which is } \\
\text { similar to the crystal habit identified by others as } \\
\text { the mineral cancrinite } \\
\text { - One particle also found to include U, Ce, La, } \\
\text { and Nd }\end{array}$ \\
\hline $\mathrm{Ca}-\mathrm{P}-\mathrm{O}$ & & $\begin{array}{l}\text { - Probably a phosphate phase } \\
\text { - Present in the unleached, DDI water-leached, } \\
\mathrm{CaCO}_{3} \text {-leached, and possibly the } \mathrm{Ca}(\mathrm{OH})_{2^{-}} \\
\text {leached samples }\end{array}$ \\
\hline \multicolumn{3}{|c|}{$\begin{array}{l}\text { Rare Phases - Only One Particle Detected in One or Two Samples } \\
\text { Phases Possibly Present in All Unleached and Leached Samples }\end{array}$} \\
\hline $\mathrm{Na}-\mathrm{Ca}-\mathrm{U}-\mathrm{O}$ & & $\begin{array}{l}\text { - Only identified in unleached residual waste } \\
\text { samples } \\
\text { - Rare }\end{array}$ \\
\hline $\begin{array}{l}\mathrm{Si}-\mathrm{Al}-\mathrm{Mg}-\mathrm{Na}-\mathrm{Fe} \\
-\mathrm{O}\end{array}$ & & - Rare; probably a silicate \\
\hline $\mathrm{Na}-\mathrm{S}-\mathrm{O}$ & & $\begin{array}{l}\text { - Rare; only one particle observed in a DDI water- } \\
\text { leached samples } \\
\text { - Possibly a Na sulfate phase }\end{array}$ \\
\hline
\end{tabular}


Table 2.7. (contd)

\begin{tabular}{|c|c|c|}
\hline $\begin{array}{l}\text { Compositions of Phases } \\
\text { Identified by SEM/EDS }\end{array}$ & Phases Identified by XRD & $\begin{array}{l}\text { Information Regarding Occurrence Based on } \\
\text { SEM/EDS Analyses }\end{array}$ \\
\hline \multicolumn{3}{|c|}{$\begin{array}{l}\text { Because } \mathrm{H} \text { is not detectable by EDS and } \mathrm{C} \text { was used for coating the SEM mounts, } \\
\text { all of the phases listed below as identified by SEM/EDS also may contain } \mathrm{H} \text { and/or C. }\end{array}$} \\
\hline $\mathrm{Zr}-\mathrm{O}$ & & $\begin{array}{l}\text { - Rare; only a few particles observed in unleached } \\
\text { and } \mathrm{CaCO}_{3} \text {-leached samples }\end{array}$ \\
\hline $\mathrm{Th}-\mathrm{O}$ & & $\begin{array}{l}\text { - Rare; only a couple particles observed in one } \\
\mathrm{CaCO}_{3} \text {-leached sample }\end{array}$ \\
\hline $\mathrm{Fe}-\mathrm{Pb}-\mathrm{O}$ & & $\begin{array}{l}\text { - Rare; only a couple particles observed in DDI } \\
\text { water-leached samples }\end{array}$ \\
\hline \multicolumn{3}{|c|}{$\begin{array}{c}\text { Phases Observed in Only the 1-Month Single-Contact } \mathrm{Ca}(\mathrm{OH})_{2} \text {-Leached Samples and } \\
\text { Thought To Have Formed from Contact with } \mathrm{Ca}(\mathrm{OH})_{2} \text { Leachant }\end{array}$} \\
\hline $\mathrm{Ca}-\mathrm{O}$ & & $\begin{array}{l}\text { - Common phase } \\
\text { - Has well-formed crystal faces } \\
\text { - Calculated EDS-based composition agrees with } \\
\text { that of } \mathrm{CaCO}_{3} \\
\end{array}$ \\
\hline $\mathrm{Ca}-\mathrm{Al}-\mathrm{Si}-\mathrm{O}$ & & $\begin{array}{l}\text { - Probably a silicate } \\
\text { - Common phase } \\
\text { - Has platy crystal habit; platy crystals often form } \\
\text { clusters } \\
\text { - Angles on corners of platelets appear to be } \\
\sim 120^{\circ}\end{array}$ \\
\hline \multirow[t]{3}{*}{$\mathrm{Ca}-\mathrm{Al}-\mathrm{O}$} & $\begin{array}{l}\text { Katoite (or hydrogrosslarite) } \\
\mathrm{Ca}_{3} \mathrm{Al}_{2}(\mathrm{OH})_{12}\end{array}$ & $\begin{array}{l}\text { - Rare phase; only few particles in one } \mathrm{Ca}(\mathrm{OH})_{2^{-}} \\
\text {leached samples } \\
\text { - Appears to be spherical intergrowth of } \\
\text { interlocking cubic crystals }\end{array}$ \\
\hline & $\begin{array}{l}\text { Calcium aluminum oxide } \\
\text { carbonate hydrate } \\
\mathrm{Ca}_{4} \mathrm{Al}_{2} \mathrm{O}_{6} \mathrm{CO}_{3} \cdot 11 \mathrm{H}_{2} \mathrm{O}\end{array}$ & \\
\hline & $\begin{array}{l}\text { Rabejacite } \\
\mathrm{Ca}\left(\mathrm{UO}_{2}\right)_{4}\left(\mathrm{SO}_{4}\right)_{2}(\mathrm{OH})_{6} \cdot 6 \mathrm{H}_{2} \mathrm{O}\end{array}$ & \\
\hline
\end{tabular}

XRD analysis also detected the presence of a small quantity of calcite in the 1-month single-contact $\mathrm{Ca}(\mathrm{OH})_{2}$-leached samples. This result agrees with the presence of a calcium carbonate phase determined by $\mathrm{SEM} / \mathrm{EDS}$ results.

The PDF database pattern for katoite (also known as hydrogrossularite or hydrogrossular), which is a possible match for the XRD patterns for $\mathrm{Ca}(\mathrm{OH})_{2}$-leached $\mathrm{C}-103$ waste solids, is for a silica-free composition of this mineral. A calcium aluminum oxide carbonate hydrate phase also was identified as a possible match for the XRD patterns for the $\mathrm{Ca}(\mathrm{OH})_{2}$-leached samples. Because EDS cannot detect $\mathrm{H}$ and identification of carbon is tenuous because it was used to coat the SEM mounts, it is not possible to ascertain if any of the $\mathrm{Ca}-\mathrm{Al}$ oxide $\pm \mathrm{H} \pm \mathrm{C}$ phases identified by SEM/EDS correspond to calcium aluminum oxide carbonate hydrate. 
Identification by XRD of the possible presence of rabejacite $\left[\mathrm{Ca}\left(\mathrm{UO}_{2}\right)_{4}\left(\mathrm{SO}_{4}\right)_{2}(\mathrm{OH})_{6} \cdot 6 \mathrm{H}_{2} \mathrm{O}\right]$ is not consistent with the SEM/EDS results. The SEM/EDS analyses indicate that one or two uranium phases are present in the unleached and leached C-103 waste solids, but the EDS data are not consistent with the possible presence of the sulfate-phase rabejacite. The EDS results suggest that calcium might sometimes be present with some particles of the uranium phases, but sulfur was never detected at greater than a few tenths of a weight percent in any of the uranium phases.

Figure 2.10A shows a low-magnification backscattered electron (BSE) micrograph of typical material present in the C-103 unleached samples. Micrographs B through D in Figure 2.10 show highermagnification SEM images of particles marked by the magenta-outlined squares in micrograph $\mathrm{A}$. The SEM/EDS analyses did not indicate any significant differences in the compositions and morphologies of particles in samples 19845, 19849, and 19850 of unleached C-103 residual waste. Most of the dark gray particles in micrograph A are aluminum oxide/hydroxide phases. The morphology of most of the aluminum oxide/hydroxide particles is consistent with gibbsite, which forms monoclinic prismatic-tabular crystals with perfect $\{001\}$ cleavage and produces a near hexagonal form. This phase corresponds to the XRD identification of gibbsite in all of the unleached and leached samples. The SEM/EDS results also suggest that the phases shown in Figure 2.10 are common to all the DDI water-leached, $\mathrm{Ca}(\mathrm{OH})_{2}$-leached, and $\mathrm{CaCO}_{3}$-leached solids from $\mathrm{C}-103$ residual waste.

It is estimated that except for gibbsite, the remaining phases in Table 2.7 make up in total less than $\sim 10 \%$ of the solids in the unleached and leached C-103 residual waste samples. The most common phases in this group as identified by SEM/EDS include (in approximate order from most to less common) one or two iron oxide/hydroxides, a silver and/or silver-mercury oxide, one or two uranium oxides (one phase also containing possibly $\mathrm{Ca}$ and $\mathrm{Na}$ ), a Na-Ca-Al silicate, and a calcium phosphate or oxide phases. Based on morphology, the SEM results suggest the presence of possibly two different iron oxide phases. Examples of the different forms of iron oxide/hydroxides are shown in Figure 2.11 and micrograph D in Figure 2.10. Both forms are present in the unleached and leached samples. The surface of one form of iron oxide/hydroxide (micrograph D in Figure 2.10 and upper right of micrograph A in Figure 2.11) appears to consist of an aggregate of rounded stubby particles (or crystals) of the iron oxide/hydroxide. The other form (middle of micrograph A in Figure 2.11) is more massive in shape, void of these rounded stubby particles, and sometimes exhibits flat surfaces that might be crystal faces. Both forms of iron oxide exist in each type of unleached and leached samples. These iron oxides/hydroxides are often intergrown with the aluminum oxide/hydroxide particles as shown in micrograph B in Figure 2.11. When chromium, nickel, lead, and manganese (typically a couple weight percent or less) are detected by EDS in these samples, these metals are associated always with the iron oxide/hydroxide phases. It is assumed that these metals likely coprecipitated with the iron oxide/hydroxide phases. Trace concentrations of uranium and technetium-99 also were sometimes detected in the iron oxides/hydroxides. It is not known if the uranium coprecipitated within the crystal structure of the iron oxides/hydroxides or occurs as discrete, submicrometer-sized particles intergrown with the iron oxides/hydroxides. 


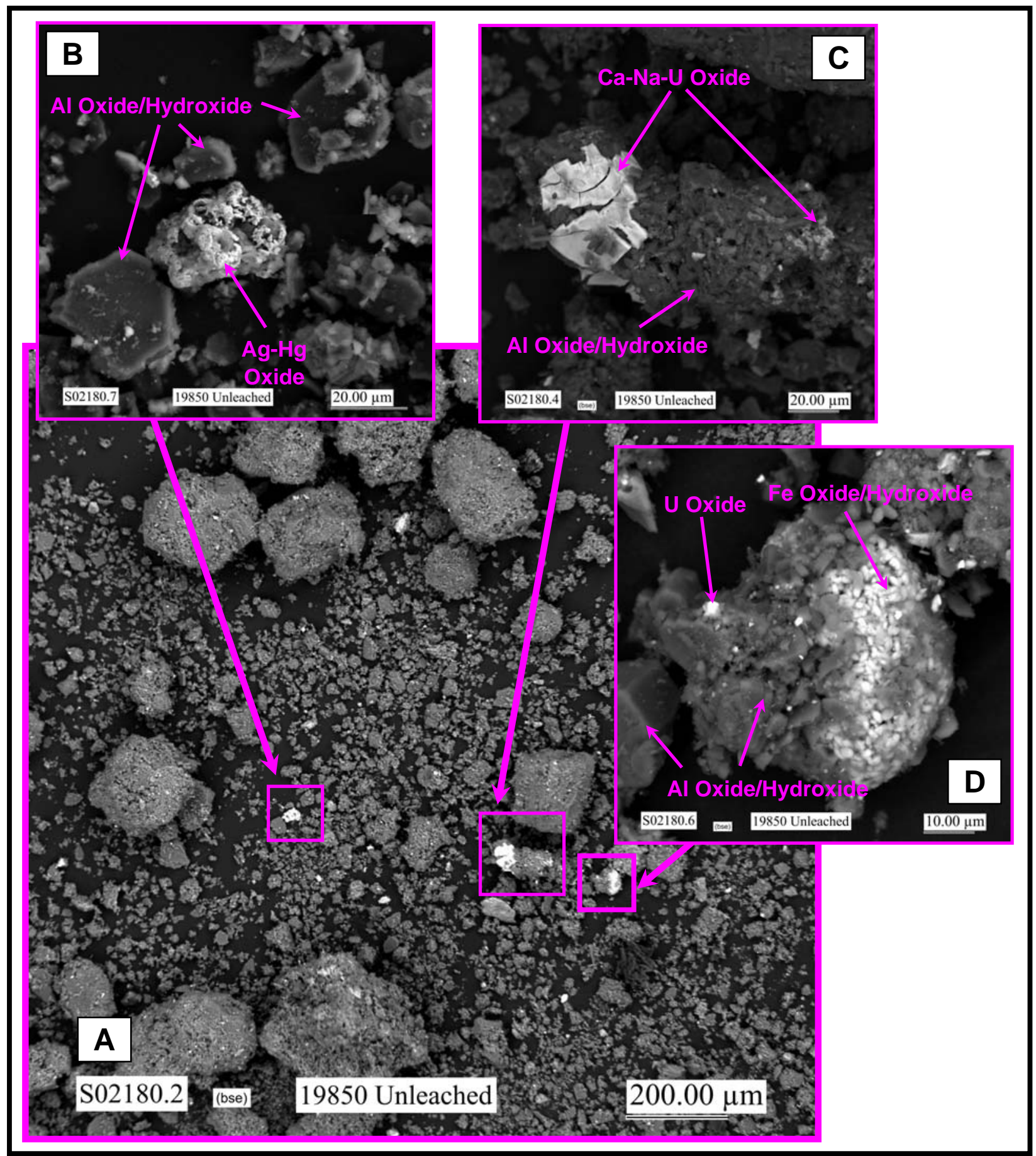

Figure 2.10. Low- (A) and High- (B, C, and D) Magnification Backscattered Electron SEM Micrographs of Typical Solids Present in Unleached C-103 Residual Waste (from Cantrell et al. 2007a) 


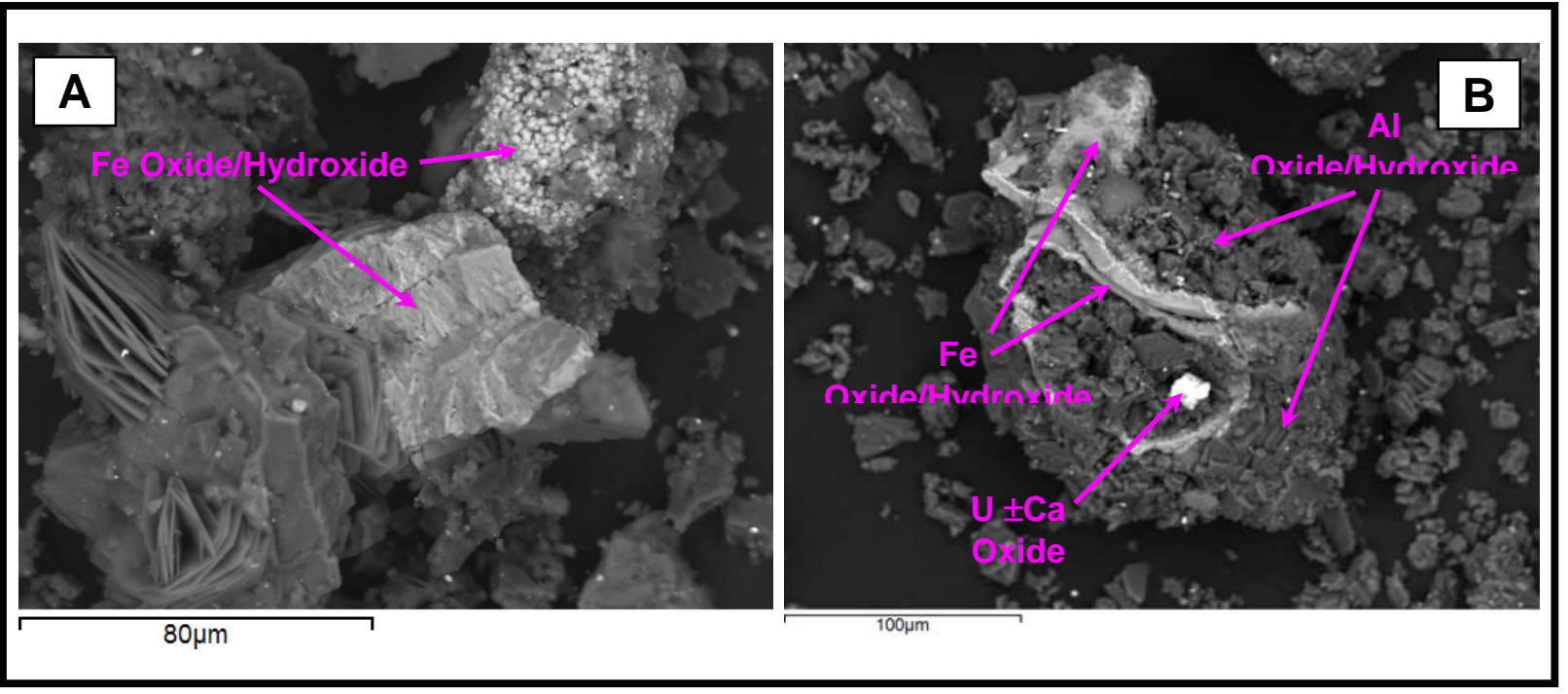

Figure 2.11. Backscattered Electron SEM Micrographs of Typical Iron Oxide/Hydroxide Solids Present in C-103 Residual Waste (from Cantrell et al. 2007a). Micrographs A and B are for $\mathrm{Ca}(\mathrm{OH})_{2}$-leached solids. Except for the platy crystals on the left in micrograph A, the majority of the gray solids in above micrographs (especially the dark gray, prismatic-tabular crystals in micrograph B) are particles of aluminum oxide/hydroxide solids.

The unleached and leached C-103 residual waste samples also contain particles of silver and/or silvermercury oxide phase. Because the concentrations of mercury in this phase appear variable and may be below detection level in some particles, it is not certain if there are one or two silver-containing phases, one having no mercury and the other containing mercury. Examples of SEM micrographs of this type of particle are shown in micrograph B in Figure 2.10.

Uranium is present in the unleached and leached C-103 samples as one or more discrete phases. One phase (shown in micrograph D of Figure 2.10) appears to be a uranium oxide (probably hydrated). Examples of the uranium oxide (or hydrate) were identified in the leached and unleached C-103 residual waste samples. Typically, the particles containing uranium were relatively small ( $\sim$ few micrometers or less in size). Micrograph $\mathrm{C}$ of Figure 2.10 shows another uranium phase composed of Ca-Na-U oxide. Trace concentrations of uranium were also sometimes detected in the iron oxides/hydroxides.

Technetium was identified by EDS in three iron oxide/hydroxide particles. These technetiumcontaining particles were found by SEM/EDS in samples of unleached, DDI water-leached, and $\mathrm{CaCO}_{3^{-}}$ leached $\mathrm{C}-103$ residual waste. The technetium concentrations in these particles ranged from 0.6 to $1.0 \mathrm{wt} \%$. This is the first time in studies of pre-retrieval and post-retrieval residual wastes from Hanford SSTs by the PNNL Residual Tank Waste Contaminant Release Project that there has been direct evidence for the presence of technetium in any phase in actual waste solids. Previous evidence for the association of technetium with iron oxides was indirect. Cantrell et al. (2006) concluded from the results of their selective extraction experiments that the recalcitrant fraction of technetium-99 in the pre-retrieval C-203 and C-204 sludges was incorporated into an iron oxyhydroxide solid phase. However, other published studies of pertechnetate and perrhenate (as an analogue of pertechnetate) sorption and coprecipitation suggest that the recalcitrant pertechnetate in tank wastes could be associated also with aluminum 
oxyhydroxides (Wakoff and Nagy 2004; Zhang et al 2000). However, technetium was never identified in any of the numerous aluminum oxide/hydroxide particles analyzed by EDS in any of the unleached or leached C-103 residual waste samples.

The SEM/EDS analyses of the 1-month single-contact $\mathrm{Ca}(\mathrm{OH})_{2}$-leached samples also identified three additional phases not observed in the unleached and other leached samples of C-103 residual waste. One phase contains calcium, oxygen, and possibly carbon, and is therefore thought to be a calcium carbonate mineral (micrograph A Figure 2.12) like calcite, which was identified by XRD. Another phase is a Ca-Al silicate (possibly hydrated and/or containing carbonate) (micrograph B in Figure 2.12). This phase has a platy crystal habit and usually occurs as clusters of intersecting individual crystals.

No phases containing the COI iodine were detected by bulk XRD or SEM/EDS analyses of the C-103 residual waste samples. This is most likely due to the low concentration of this $\mathrm{COI}$ in the $\mathrm{C}-103$ residual waste.

\subsubsection{Solid Phases: C-106}

Residual solid waste from C-106 was characterized using XRD and SEM/EDS techniques in the contaminant release study of Deutsch et al. (2007a). Additional characterization studies were completed later using synchrotron-based x-ray analysis techniques (Deutsch et al. 2005). Results of the XRD and SEM/EDS characterization studies by Deutsch et al. (2007a) are summarized in Table 2.8. The crystalline phases identified by bulk XRD are consistent with phases observed by SEM/EDS analysis. Several phases observed by SEM/EDS, however, were not detected by XRD (Deutsch et al. 2007a). Some of the phases that were not identified by XRD may be amorphous or present at concentrations too low for detection by XRD, which requires crystalline phases to be present at 1 to $5 \mathrm{wt} \%$ or greater of the sample. Figure 2.13 shows BSE SEM images typical for unleached C-106 residual waste. The phase that consists of Mn-Al-Fe-Na-P-Si-Ca-O $\pm \mathrm{C} \pm \mathrm{H}$ (see particles indicated by arrows in Figure 2.13) was present in all of the unleached and water-leached waste samples from tank C-106. The identity of this phase is not known. The morphology of these particles resembles that expected for $\mathrm{MnCO}_{3}$, but the EDS analyses are not consistent with this composition. The texture of these particles, as characterized by SEM, does not provide any definitive information to evaluate if this material is amorphous or crystalline and appears in some instances to be a coating on particles of other compositions. Moreover, the results of an extraction of the waste with HF acid suggest that this material with this composition may consist of more than one phase.

Bechtold et al. (2003) used XRD and SEM/EDS to characterize pre-retrieval samples of C-106 unleached waste and a waste leached with $1 \mathrm{M}$ oxalic acid. Table 2.8 compares the XRD and SEM/EDS results for post-retrieval residual waste (Deutsch et al. 2007a) to those reported by Bechtold et al. (2003) for pre-retrieval C-106 waste treated with $1 \mathrm{M}$ oxalic acid, which was subsequently used as the retrieval solution. The XRD and SEM/EDS results from Deutsch et al. (2007a) overall are consistent with phases identified by Bechtold et al. (2003). Several phases observed by SEM/EDS in Deutsch et al. (2007a) do not correspond to any of the phases identified by Bechtold et al. (2003). For example, the phase containing Mn-Al-Fe-Na-P-Si-Ca-O $\pm \mathrm{C} \pm \mathrm{H}$ does not correspond to any of the solids identified by Bechtold et al. (2003). 


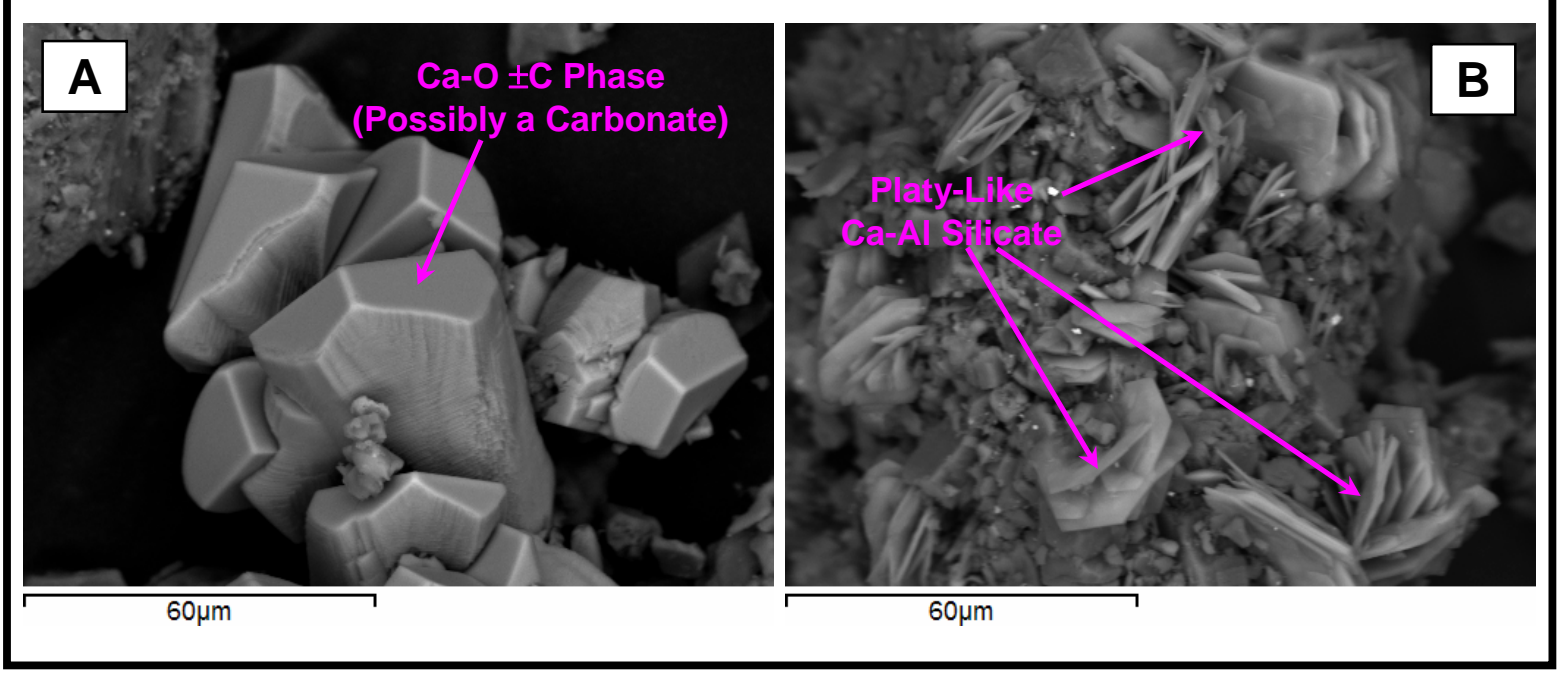

Figure 2.12. Backscattered Electron SEM Micrographs Showing the Ca Carbonate (A) and Ca-Al Silicate (B) Phases Identified in the 1-Month Single-Contact $\mathrm{Ca}(\mathrm{OH})_{2}$-Leached Samples of C-103 Residual Waste (from Cantrell et al. 2007a)

Table 2.8. Summary of XRD and SEM/EDS Characterization Results for C-106 Residual Waste (from Deutsch et al. 2007a) Compared to Those for Tank C-106 Waste Treated with Oxalic Acid (from Bechtold et al. 2003)

\begin{tabular}{|c|c|c|}
\hline \multicolumn{2}{|c|}{$\begin{array}{c}\text { Characterization Results from } \\
\text { Deutsch et al. (2007a) for } \\
\text { C-106 Residual Waste (Waste Retrieved Using Oxalic Acid) }\end{array}$} & \multirow{2}{*}{$\begin{array}{l}\text { Characterization Results from } \\
\text { Bechtold et al. (2003) for } \\
\text { C-106 Pre-Retrieval Waste Leached } \\
\text { by } 1 \text { M Oxalic Acid }\end{array}$} \\
\hline XRD Analyses & SEM/EDS Analyses & \\
\hline & Mn-Al-Fe-Na-P-Si-Ca-O $\pm \mathrm{C} \pm \mathrm{H}$ & \\
\hline Gibbsite & \multirow{2}{*}{$\mathrm{Al}-\mathrm{O} \pm \mathrm{H}$} & Gibbsite \\
\hline Böhmite & & Böhmite \\
\hline Dawsonite & $\mathrm{Al}-\mathrm{Na}-\mathrm{O}-\mathrm{C} \pm \mathrm{H}$ & \\
\hline Hematite & $\begin{array}{l}\mathrm{Fe}-\mathrm{Cr}-\mathrm{O} \pm \mathrm{C} \pm \mathrm{H} \\
\mathrm{Fe}-\mathrm{Mn}-\mathrm{O} \pm \mathrm{C} \pm \mathrm{H}\end{array}$ & Hematite \\
\hline Rhodochrosite & \multirow{2}{*}{$\begin{array}{l}\text { Mn-O-C } \pm \mathrm{H} \text { (possibly two different } \\
\text { phases, based on morphology) }\end{array}$} & \\
\hline Lindbergite $\left(\mathrm{MnC}_{2} \mathrm{O}_{4} \cdot 2 \mathrm{H}_{2} \mathrm{O}\right)$ & & "Mn(II) oxalate" \\
\hline Whewellite $\left(\mathrm{CaC}_{2} \mathrm{O}_{4} \cdot \mathrm{H}_{2} \mathrm{O}\right)$ & $\mathrm{Ca}-\mathrm{O} \pm \mathrm{C} \pm \mathrm{H}$ & \\
\hline \multirow[t]{6}{*}{ Possible Ag-Hg phase } & $\begin{array}{l}\text { Possibly one or two phases with } \\
\mathrm{Ag}-\mathrm{Hg} \pm \mathrm{Fe} \pm \mathrm{Pb} \pm \mathrm{Cu} \pm \mathrm{O} \pm \mathrm{H}\end{array}$ & \\
\hline & $\mathrm{Mn}-\mathrm{O}-\mathrm{P} \pm \mathrm{Al} \pm \mathrm{C} \pm \mathrm{H}$ & \\
\hline & Si-Al-Na-O $\pm \mathrm{C} \pm \mathrm{H}$ & \\
\hline & REE-rich oxide & Nd-rich particles \\
\hline & $\mathrm{Ca}-\mathrm{Si}-\mathrm{Al}-\mathrm{O} \pm \mathrm{C} \pm \mathrm{H}$ & \\
\hline & $\mathrm{Pb}$-containing phase & $\mathrm{Pb}$-rich particles \\
\hline
\end{tabular}



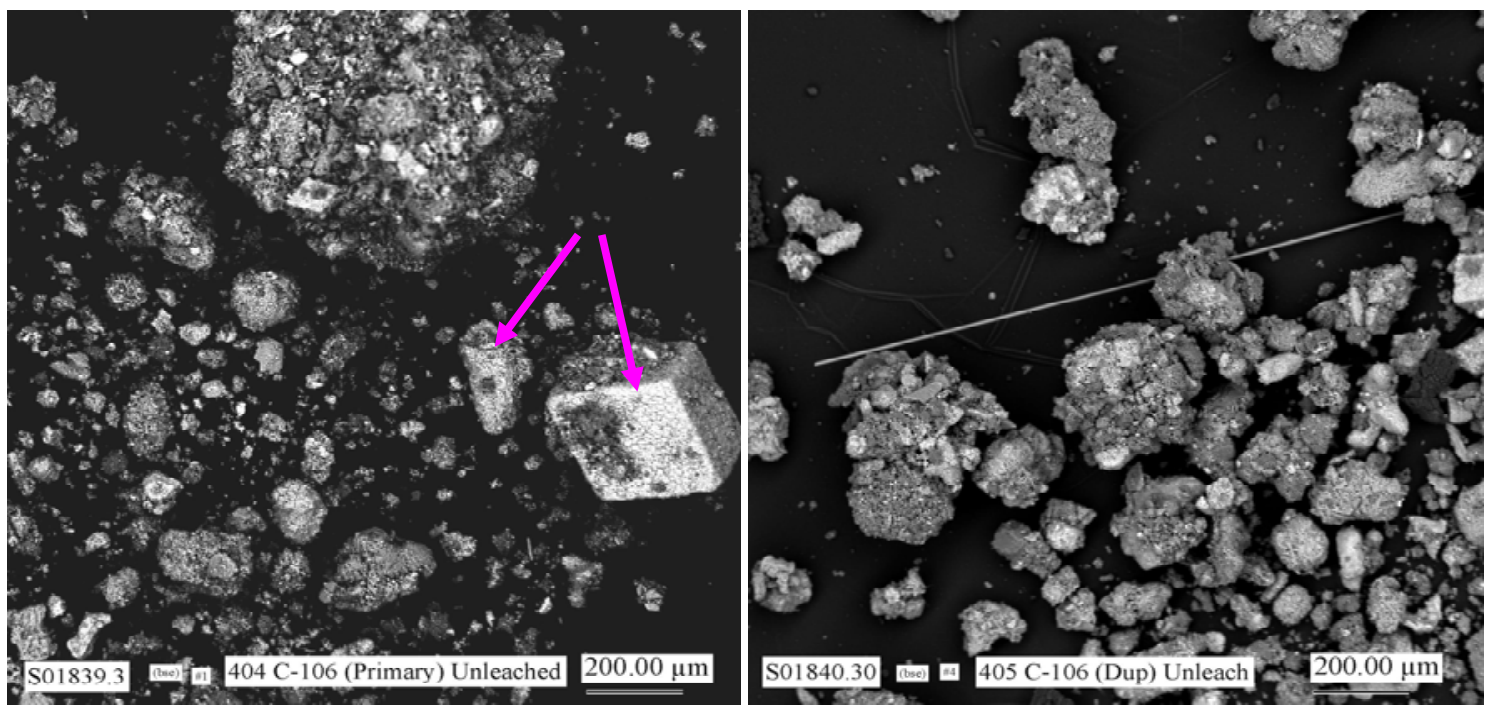

Figure 2.13. Low-Magnification Backscattered Electron SEM Micrographs of Particles Present in the Unleached Tank C-106 Residual Waste (from Deutsch et al. 2007a). The particles indicated by arrows consist of Mn-Al-Fe-Na-P-Si-Ca-O $\pm \mathrm{C} \pm \mathrm{H}$. The long needle shown in the right micrograph was from fibrous glass wool used in the laboratory to prevent dispersion of these radioactive powders. These needles are not present in the residual waste.

Two C-106 residual waste samples were also analyzed using various synchrotron based $\mathrm{x}$-ray techniques, including microscanning $\mathrm{x}$-ray fluorescence ( $\mu \mathrm{SXRF})$, $\mathrm{x}$-ray absorption near edge structure (XANES) spectroscopy, extended $\mathrm{x}$-ray absorption fine structure (EXAFS) spectroscopy, and micro x-ray diffraction ( $\mu \mathrm{XRD})$ (Deutsch et al. 2005). The first sample was an unleached C-106 residual waste. The second sample was leached with DDI water to evaluate the soluble (relatively mobile) constituents in the residual waste. With a few minor exceptions, the analyses by $\mu$ SXRF, XANES, and EXAFS indicate overall that the C-106 unleached and water-leached samples appear to be relatively similar in terms of the speciation of the major components and the contaminants of interest that could be examined with synchrotron $\mathrm{x}$-ray techniques.

The $\mu$ SXRF maps for both the unleached and leached C-106 samples indicated the presence of silver that occurs as small discrete particles. Spectra from XANES and EXAFS analyses collected from four locations within the unleached C-106 residual waste sample containing high concentrations of silver indicated that the majority of the silver was in the zero-valent (metallic) form. Similar results were found for the C-106 water-leached sample. The results also suggest that some of the silver is in a more oxidized form. This phase was not identified, but $\mathrm{Ag}_{2} \mathrm{O}, \mathrm{Ag}_{2} \mathrm{CO}_{3}$, and $\mathrm{Ag}_{2} \mathrm{C}_{2} \mathrm{O}_{4}$ (silver oxalate) are possible candidates. In addition, it was determined that small amounts of zero-valent mercury frequently occurred with the silver, probably as an amalgam. Identification of the silver-mercury phase(s) by synchrotron based x-ray techniques is consistent the detection of such phases by the bulk XRD and SEM/EDS analyses (see Table 2.8).

Spectra measured by XANES and EXAFS and collected from a number of locations containing high manganese concentrations within the unleached and leached residual waste samples indicated that the majority of manganese occurs as Mn(II) similar to the XANES and EXAFS spectra for rhodochrosite $\left(\mathrm{MnCO}_{3}\right)$. In addition, the presence of a $\mathrm{Mn}$ (II)-oxalate and a $\mathrm{Mn}$ (III)-containing oxide or oxyhydroxide 
phase are also possible. These results are consistent with previous bulk XRD analysis of the samples that identified the presence of rhodochrosite (see Table 2.8).

Spectra from XANES and EXAFS were collected also from a number of locations containing high concentrations of uranium, chromium, or iron within the unleached and leached C-106 residual waste samples. The XANES and EXAFS results indicated that uranium occurs primarily in the hexavalent oxidation state $[\mathrm{U}(\mathrm{VI})]$. In the water-leached sample, the XANES spectra suggest that a small fraction of the uranium may be present as U(IV). The spectra collected from a number of locations having high chromium concentrations showed that the majority of the chromium is in the reduced trivalent [Cr(III)] oxidation state. However, XANES analysis of iron indicated that the majority of iron present in both C-106 unleached and water-leached residual waste was in the oxidized trivalent [Fe(III)] oxidation state.

Micro x-ray diffraction patterns also were collected on the unleached and leached samples. Results of the $\mu$ XRD analysis identified crystalline phases consistent with those previously identified by bulk XRD. The $\mu \mathrm{XRD}$ patterns were consistent with the presence of rhodochrosite, hematite, dawsonite, gibbsite, and silver metal. Silver metal that was positively identified in the C-106 sample by XANES and EXAFS was not detected by bulk XRD.

In addition to the testing described above, the C-106 residual waste was leached with $0.01 \mathrm{M}$ $\mathrm{Ca}(\mathrm{OH})_{2}$ and with $\mathrm{Ca}\left(\mathrm{CO}_{3}\right)_{2}$ saturated solutions (Deutsch et al. 2006) to simulate long-term conditions in which the SST might be filled with a cementitious material after final waste retrieval. X-ray diffraction and SEM/EDS analyses also were completed on residual waste samples after leaching with these solutions. Table 2.9 compares the XRD and SEM/EDS results for the $\mathrm{Ca}(\mathrm{OH})_{2}$-and $\mathrm{CaCO}_{3}$-leached samples (Deutsch et al. 2006) relative to those from Deutsch et al. (2005) for the C-106 residual waste used as starting material for these leaching tests. Except for the presence of calcite $\left(\mathrm{CaCO}_{3}\right)$, the phases identified from the XRD patterns for the $\mathrm{Ca}(\mathrm{OH})_{2}$ - and $\mathrm{CaCO}_{3}$-leached samples were also present in the XRD patterns for the $\mathrm{C}-106$ unleached residual waste. Absent from the XRD patterns for the leached samples, however, were hematite $\left(\mathrm{Fe}_{2} \mathrm{O}_{3}\right)$, lindbergite $\left(\mathrm{MnC}_{2} \mathrm{O}_{4} \cdot 2 \mathrm{H}_{2} \mathrm{O}\right)$, and rhodochrosite $\left(\mathrm{MnCO}_{3}\right)$, which were identified in the unleached material. Identification of böhmite $[\mathrm{AlO}(\mathrm{OH})]$ and dawsonite $\left[\mathrm{NaAlCO}_{3}(\mathrm{OH})_{2}\right]$ in the $\mathrm{Ca}(\mathrm{OH})_{2}$-leached and the 1-month $\mathrm{CaCO}_{3}$-leached samples, respectively, was problematic; therefore, these two phases also need to be considered as possibly absent in the $\mathrm{Ca}(\mathrm{OH})_{2}$ and $\mathrm{CaCO}_{3}$-leached samples. It was not possible from the XRD or SEM/EDS analyses to determine if the lack of identification of hematite, lindbergite, rhodochrosite $\left(\mathrm{MnCO}_{3}\right)$, böhmite, and dawsonite is due to their dissolution during contact with the $\mathrm{Ca}(\mathrm{OH})_{2}$ and $\mathrm{CaCO}_{3}$ leachates, or to their concentrations being too low to be detected by bulk XRD. Because the phases are not expected to dissolve in the $\mathrm{Ca}(\mathrm{OH})_{2}$ and $\mathrm{CaCO}_{3}$ leachants, their absence most likely can be ascribed to sample inhomogeneity or detection limit issues. Although particles containing uranium were identified by synchrotron-based x-ray techniques, no phases containing COIs, such as iodine, technetium, uranium, and the actinides, were detected by bulk XRD or SEM/EDS analyses of the C-106 residual waste samples. This is most likely due to the low mass concentrations of COIs in the $\mathrm{C}-106$ residual waste.

\subsubsection{Solid Phases: C-202}

Residual solid waste from C-202 was characterized using XRD and SEM/EDS techniques in the contaminant release study of Deutsch et al. (2007c). The results of the XRD and SEM/EDS analyses of C-202 residual waste are summarized in Table 2.10. Samples characterized by bulk XRD and SEM/EDS 
Table 2.9. Comparison of XRD and SEM/EDS Results for the Unleached Samples of C-106 Residual Waste (from Deutsch et al. 2007a) to the Results for the $\mathrm{Ca}(\mathrm{OH})_{2}$ - and $\mathrm{CaCO}_{3}$-Leached Samples of C-106 Residual Waste (from Deutsch et al. 2006)

\begin{tabular}{|c|c|c|c|c|c|}
\hline \multicolumn{2}{|c|}{$\begin{array}{l}\text { Unleached Residual Waste } \\
\text { (from Deutsch et al. 2007a) }\end{array}$} & \multicolumn{2}{|c|}{$\begin{array}{l}\mathrm{Ca}(\mathrm{OH})_{2} \text {-Leached Residual Waste: } \\
\text { 1-Month and Stage } 6 \text { Sequential Leaches } \\
\text { (from Deutsch et al. 2006) }\end{array}$} & \multicolumn{2}{|c|}{$\begin{array}{l}\mathrm{CaCO}_{3} \text {-Leached Residual Waste: } \\
\text { 1-Month and Stage } 6 \text { Sequential Leaches } \\
\text { (from Deutsch et al. 2006) }\end{array}$} \\
\hline XRD Analyses & SEM/EDS Analyses & XRD Analyses & SEM/EDS Analyses & XRD Analyses & SEM/EDS Analyses \\
\hline & $\begin{array}{c}\text { Mn-Al-Fe-Na-P-Si-Ca- } \\
\mathrm{O} \pm \mathrm{C} \pm \mathrm{H}\end{array}$ & & & & \\
\hline & & & $\begin{array}{c}\text { Ca-Mn-Al-Si-Fe- } \\
\pm \mathrm{Pb} \pm \mathrm{REE}(\mathrm{Ce}) \pm \mathrm{Cr}-\mathrm{P}-\mathrm{O} \pm \\
\mathrm{C} \pm \mathrm{H}\end{array}$ & & $\begin{array}{c}\text { Ca-Mn-Al-Si-Fe- } \\
\pm \mathrm{Pb} \pm \mathrm{REE}(\mathrm{Ce}) \pm \mathrm{Cr}-\mathrm{P}-\mathrm{O} \pm \\
\mathrm{C} \pm \mathrm{H}\end{array}$ \\
\hline & & & $\begin{array}{c}\text { Ca-Al-O-C } \pm \mathrm{H} \text { (only in } \\
\text { Stage } 6 \text { sequential leach) }\end{array}$ & & $\mathrm{Ca}-\mathrm{Al}-\mathrm{O}-\mathrm{C} \pm \mathrm{H}$ \\
\hline Gibbsite $\left[\mathrm{Al}(\mathrm{OH})_{3}\right]$ & \multirow{2}{*}{$\mathrm{Al}-\mathrm{O} \pm \mathrm{H}$} & Gibbsite & \multirow{2}{*}{$\mathrm{Al}-\mathrm{O} \pm \mathrm{H} \pm \mathrm{C}$} & Gibbsite & $\mathrm{Al}-\mathrm{O} \pm \mathrm{H} \pm \mathrm{C}$ \\
\hline Böhmite [AlO(OH)] & & Böhmite (possibly) & & & \\
\hline $\begin{array}{c}\text { Dawsonite } \\
{\left[\mathrm{NaAlCO}_{3}(\mathrm{OH})_{2}\right]}\end{array}$ & Al-Na-O-C $\pm \mathrm{H}$ & & & $\begin{array}{c}\text { Dawsonite (only in } \\
1 \text {-month leached) }\end{array}$ & \\
\hline Hematite $\left(\mathrm{Fe}_{3} \mathrm{O}_{4}\right)$ & $\begin{array}{c}\mathrm{Fe}-\mathrm{Cr}-\mathrm{O} \pm \mathrm{C} \pm \mathrm{H} \\
\mathrm{Fe}-\mathrm{Mn}-\mathrm{O} \pm \mathrm{C} \pm \mathrm{H}\end{array}$ & & & & \\
\hline $\begin{array}{c}\text { Rhodochrosite } \\
\left(\mathrm{MnCO}_{3}\right)\end{array}$ & \multirow{2}{*}{$\begin{array}{c}\text { Mn-O-C } \pm \mathrm{H} \text { (possibly two } \\
\text { different phases based on } \\
\text { morphology) }\end{array}$} & & & & \\
\hline $\begin{array}{c}\text { Lindbergite } \\
\left(\mathrm{MnC}_{2} \mathrm{O}_{4} \cdot 2 \mathrm{H}_{2} \mathrm{O}\right)\end{array}$ & & & & & \\
\hline \multirow[t]{2}{*}{$\begin{array}{c}\text { Whewellite } \\
\left(\mathrm{CaC}_{2} \mathrm{O}_{4} \cdot \mathrm{H}_{2} \mathrm{O}\right) \\
\end{array}$} & $\mathrm{Ca}-\mathrm{O} \pm \mathrm{C} \pm \mathrm{H}$ & Whewellite & \multirow[t]{2}{*}{$\mathrm{Ca}-\mathrm{O} \pm \mathrm{C} \pm \mathrm{H}$} & Whewellite & \multirow[t]{2}{*}{$\mathrm{Ca}-\mathrm{O} \pm \mathrm{C} \pm \mathrm{H}$} \\
\hline & & Calcite $\left(\mathrm{CaCO}_{3}\right)$ & & Calcite & \\
\hline \multirow[t]{7}{*}{ Possible Ag-Hg phase } & $\begin{array}{l}\text { Possibly } 1 \text { or } 2 \text { phases with } \\
\mathrm{Ag}-\mathrm{Hg} \pm \mathrm{Fe} \pm \mathrm{Pb} \pm \mathrm{Cu} \pm \mathrm{O} \pm \mathrm{H}\end{array}$ & & Ag-Hg (small particles) & & Ag-Hg (small particles) \\
\hline & & & $\begin{array}{l}\text { Mn-Na-P-O } \pm \mathrm{C} \pm \mathrm{H} \text { (only } \\
\text { one particle cluster in } \\
\text { 1-month sequential leach) }\end{array}$ & & \\
\hline & $\mathrm{Mn}-\mathrm{O}-\mathrm{P} \pm \mathrm{Al} \pm \mathrm{C} \pm \mathrm{H}$ & & & & \\
\hline & Si-Al-Na-O $\pm \mathrm{C} \pm \mathrm{H}$ & & & & \\
\hline & REE-rich oxide & & & & \\
\hline & $\mathrm{Ca}-\mathrm{Si}-\mathrm{Al}-\mathrm{O} \pm \mathrm{C} \pm \mathrm{H}$ & & & & \\
\hline & Pb-containing phase & & & & \\
\hline
\end{tabular}


Table 2.10. Summary of XRD and SEM/EDS Characterization Results for C-202 and C-203 Residual Wastes (from Deutsch et al. 2007c)

\begin{tabular}{|c|c|c|c|}
\hline \multicolumn{2}{|c|}{ C-202 Residual Waste } & \multicolumn{2}{|c|}{ C-203 Residual Waste } \\
\hline XRD Analyses & SEM/EDS Analyses & XRD Analyses & SEM/EDS Analyses \\
\hline $\begin{array}{c}\text { Mostly amorphous phases; } \\
\text { no crystalline phases } \\
\text { identified }\end{array}$ & & $\begin{array}{c}\text { Mostly amorphous phases; } \\
\text { no crystalline phases } \\
\text { identified }\end{array}$ & \\
\hline & $\begin{array}{l}\text { U-Na-C-O-P } \pm \mathrm{H} \text { (probably } \\
\text { amorphous); possibly } \\
\text { more than one phase }\end{array}$ & & $\begin{array}{c}\text { U-Na-C-O-P } \pm \mathrm{H} \text { (probably } \\
\text { amorphous); possibly } \\
\text { more than one phase; } \\
\text { sometimes with trace } \\
\text { concentrations of Si and } \\
\text { Al }\end{array}$ \\
\hline & $\begin{array}{c}\text { Fe-O; often with low } \\
\text { concentrations of } \mathrm{Mn}, \mathrm{Cr} \text {, } \\
\text { and } \mathrm{Pb}\end{array}$ & & $\begin{array}{c}\mathrm{Fe}-\mathrm{O} \text {; often with low } \\
\text { concentrations of } \mathrm{Cr}, \mathrm{Mn} \text {, } \\
\mathrm{Pb} \text {, and } \mathrm{Cu}\end{array}$ \\
\hline $\begin{array}{l}\text { Quartz }\left(\mathrm{SiO}_{2}\right) \text { (in } \\
\text { unleached sample; likely } \\
\text { from blowing dust or } \\
\text { sediment that fell into the } \\
\text { tank) }\end{array}$ & & & \\
\hline
\end{tabular}

included unleached, 1-month single-contact leached DDI water extraction, 1-month single-contact $\mathrm{Ca}(\mathrm{OH})_{2}$ leached, and 1-month single-contact $\mathrm{CaCO}_{3}$ leached residual waste from tank C-202. The XRD results indicate that these samples contain mostly amorphous (non-crystalline) solids. All of the XRD patterns contained a broad diffraction profile (or hump) from approximately 10 to $30^{\circ} 2 \theta$. This broad feature likely originates from diffraction from the Kapton ${ }^{\circledR}$ film of the sample holder and colloidion binder. This broad hump may also include diffraction contributions from amorphous material in the samples. Except for the possible presence of quartz $\left(\mathrm{SiO}_{2}\right)$ in the sample of unleached residual waste, no crystalline phases other than corundum (used as a $2 \theta$ internal standard) were identified in these samples. Based on published tank chemistry and characterization information, quartz is not expected to be a component in these wastes. Because quartz is one of the principal minerals in Hanford sediments, its presence in this residual waste likely resulted from blowing dust or sediment that fell into the tank during sampling or other tank operation activities. Only one unidentified reflection was found in the XRD patterns for C-202 residual waste. This was a low-angle reflection at $15.02{ }^{\circ} 2 \theta$ (5.89 $\AA$ ) noted in the XRD pattern for the 1-month single-contact $\mathrm{Ca}(\mathrm{OH})_{2}$ leached sample. Otherwise, there were no major unassigned reflections in the XRD patterns, which suggests that these samples did not contain any major crystalline phases present optimally at more than $\sim 1$ to $5 \mathrm{wt} \%$ of the sample mass.

Figure 2.14 shows BSE SEM micrographs taken at low magnification of typical material present in unleached and leached C-202 residual waste. The SEM/EDS analyses show the C-202 residual waste consists of particles generally having one of two common compositions. One composition consists of $\mathrm{U}-\mathrm{Na}-\mathrm{C}-\mathrm{O}-\mathrm{P} \pm \mathrm{H}$ (see bright white solid in Figure 2.14). The second composition corresponds to an iron oxide that often contains trace amounts of manganese and chromium and sometimes lead. Particles and aggregates that are gray in Figure 2.15 consist of this iron oxide (typically, the darker the gray - the 


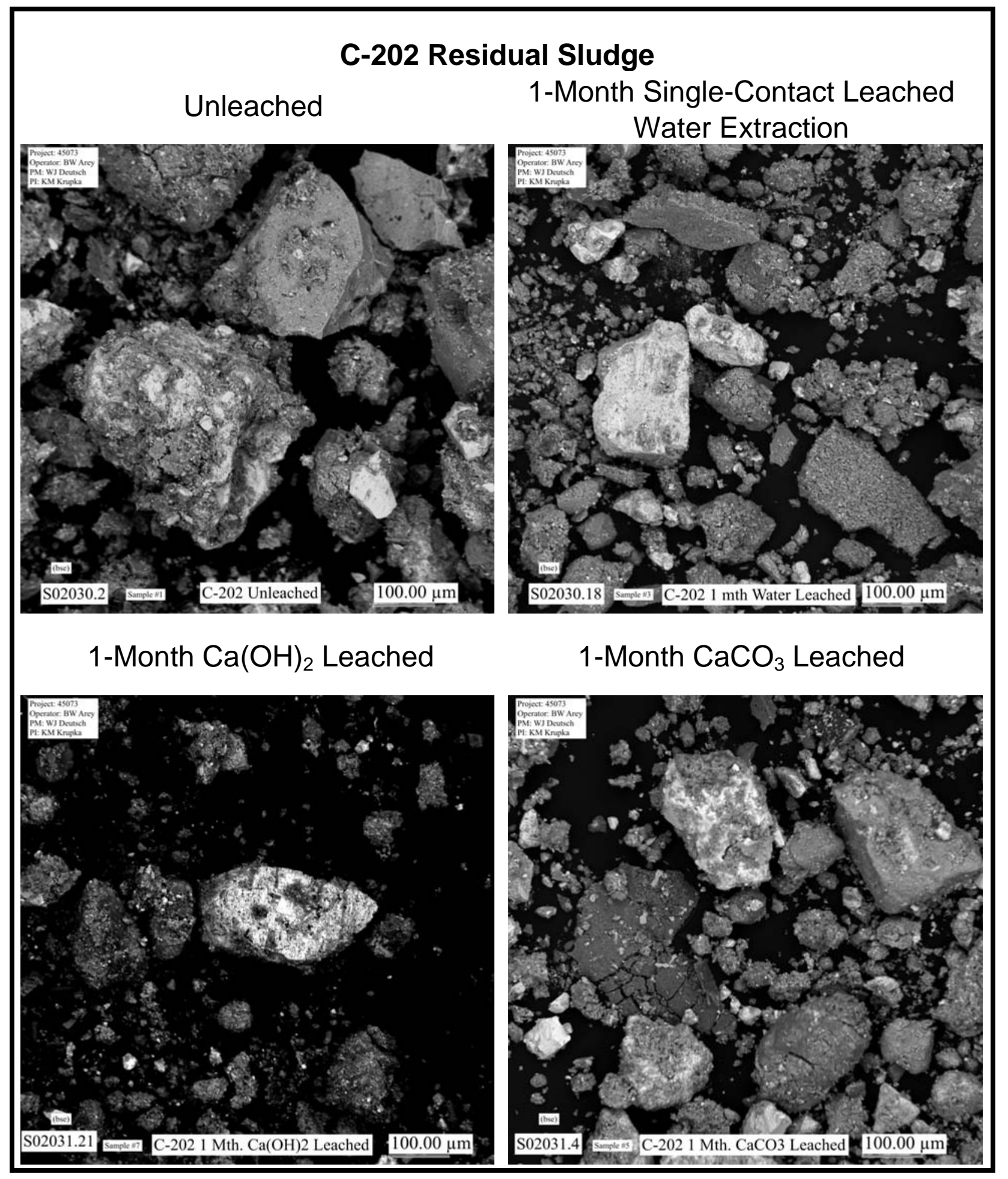

Figure 2.14. Backscattered Electron SEM Micrographs for Unleached, 1-Month Single-Contact Double Deionized Water Extraction-Leached, 1-Month Single-Contact $\mathrm{Ca}(\mathrm{OH})_{2}$-Leached, and 1-Month Single-Contact $\mathrm{CaCO}_{3}$-Leached Residual Waste from Tank C-202 (from Deutsch et al. 2007c) 


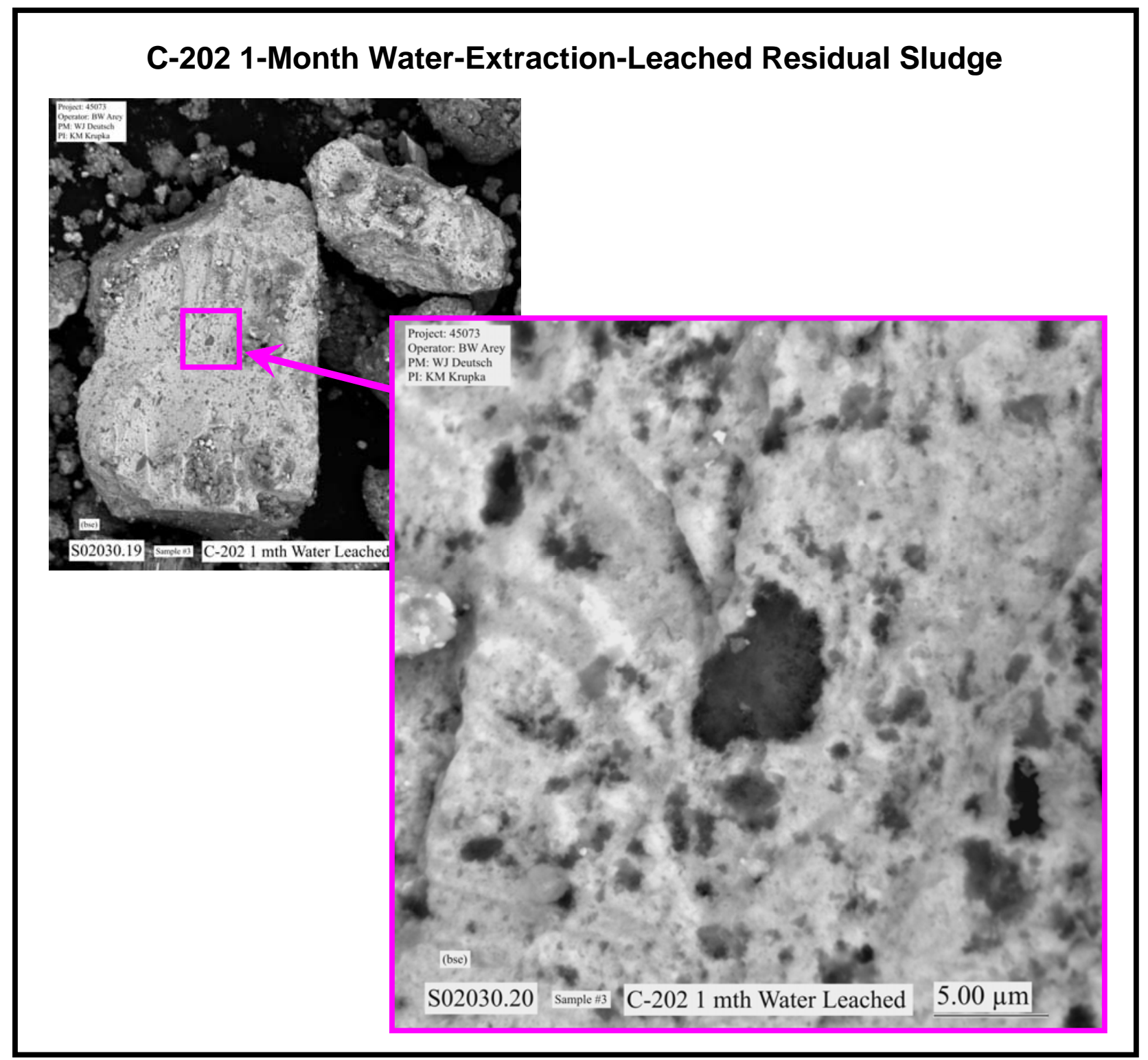

Figure 2.15. Backscattered Electron Micrographs Showing Porous Uranium-Containing Solid as a Coating and Intergrowth with Iron Oxide in 1-Month Single-Contact Double Deionized Water Extraction-Leached Solid from C-202 Residual Waste (from Deutsch et al. 2007c)

greater the iron oxide content of the aggregate) in total or in part. Figure 2.15 shows the porous U-Na-C$\mathrm{O}-\mathrm{P} \pm \mathrm{H}$ as a coating and intergrowth with iron oxide. The SEM/EDS results show that all of the analyzed samples contain a combination of individual and aggregate particles from less than a micrometer to several hundred micrometers in size. The particles were nondescript and appeared to be amorphous due to a general absence of crystal faces.

No phases containing the COIs iodine, technetium, and the actinides were detected by bulk XRD or SEM/EDS analyses of the C-202 residual waste samples. This is most likely due to the low mass concentrations of these COIs in the C-202 residual waste. 


\subsubsection{Solid Phases: C-203}

Residual solid waste from C-203 was characterized using XRD and SEM/EDS techniques in the contaminant release study of Deutsch et al. (2007c). Like the XRD results for the C-202 unleached and leached C-202 samples (see Table 2.10), the XRD patterns indicated that the C-203 samples consist of essentially ( $\geq \sim 90 \%$ ) amorphous (non-crystalline) material.

Figure 2.16 shows BSE SEM micrographs at low magnifications of unleached (micrographs on left side) and sequential-leached DDI water extraction (micrographs on right side) samples of C-203 residual waste. The unleached and 1-month single-contact DDI water-leached samples of C-203 residual waste appear to contain more large-particle aggregates than the sequential-leached DDI water extraction samples. Deutsch et al. (2007c) assumed that this disaggregation occurred because of dissolution reactions during the sequential-leach testing and/or sample centrifugation and not from preparation of the SEM mount.

The results of the SEM/EDS analyses of C-203 residual waste were consistent also with those for the C-202 waste (Table 2.10). All of the analyzed C-203 residual waste samples contained mostly particle aggregates consisting of U-Na-C-O-P $\pm \mathrm{H}$ (brightest particles in Figure 2.16), sometimes with trace levels of silicon and aluminum. Based on the SEM results, the U-Na-C-O-P \pm H solids in the unleached and sequential water-leached C-203 samples occurred with three morphologies: 1) porous aggregates; 2) large, dense, rounded particles; and 3) conglomerates. The porous aggregates and dense, rounded particles had noticeably different surface textures and are similar to those observed in the C-202 residual waste. A few particles were observed to also have apparent pyramidal faces. As with the C-202 residual waste samples, Deutsch et al. (2007c) suggested that the different surface textures and morphologies were consistent with the presence of two or more types of $\mathrm{U}-\mathrm{Na}-\mathrm{C}-\mathrm{O}-\mathrm{P} \pm \mathrm{H}$ phases in the unleached C-203 residual waste.

The C-203 samples also contained a small number of iron oxide particles (see dark gray particles indicated in micrograph in lower right of Figure 2.16). The iron oxide particles often occur as large individual or conglomerate particles and often contain low concentrations of chromium, manganese, lead, and copper.

Like the results from the characterization of the C-202 residual waste samples, no phases containing the COIs iodine, technetium, and the actinides were detected by bulk XRD or SEM/EDS analyses of the C-203 residual waste samples. This is most likely due to the low mass concentrations of these COIs in the $\mathrm{C}-203$ residual waste.

\subsubsection{Comparison of Solids Identified in C-202 and C-203 Residual Waste to Those in C-203 and C-204 Pre-Retrieval Waste}

Although a limited number of SST residual wastes have been characterized to date, some similarities have been identified with respect to solids present in pre-retrieval SST wastes. For example, the SEM/EDS results for C-202 and C-203 residual waste (Deutsch et al. 2007c) are generally consistent with those for the water-leached pre-retrieval wastes from tanks C-203 and C-204 reported by Deutsch et al. (2007b). ${ }^{(a)}$ Characterization studies of pre-retrieval wastes from tanks C-203 and C-204 identified the

(a) When Deutsch et al. (2007b) completed their Tier 1 characterization of the C-203 and C-204 pre-retrieval wastes, their testing protocol at that time did not include the $\mathrm{Ca}(\mathrm{OH})_{2}$ and $\mathrm{CaCO}_{3}$ leach solution measurements used in their current testing methodology. 


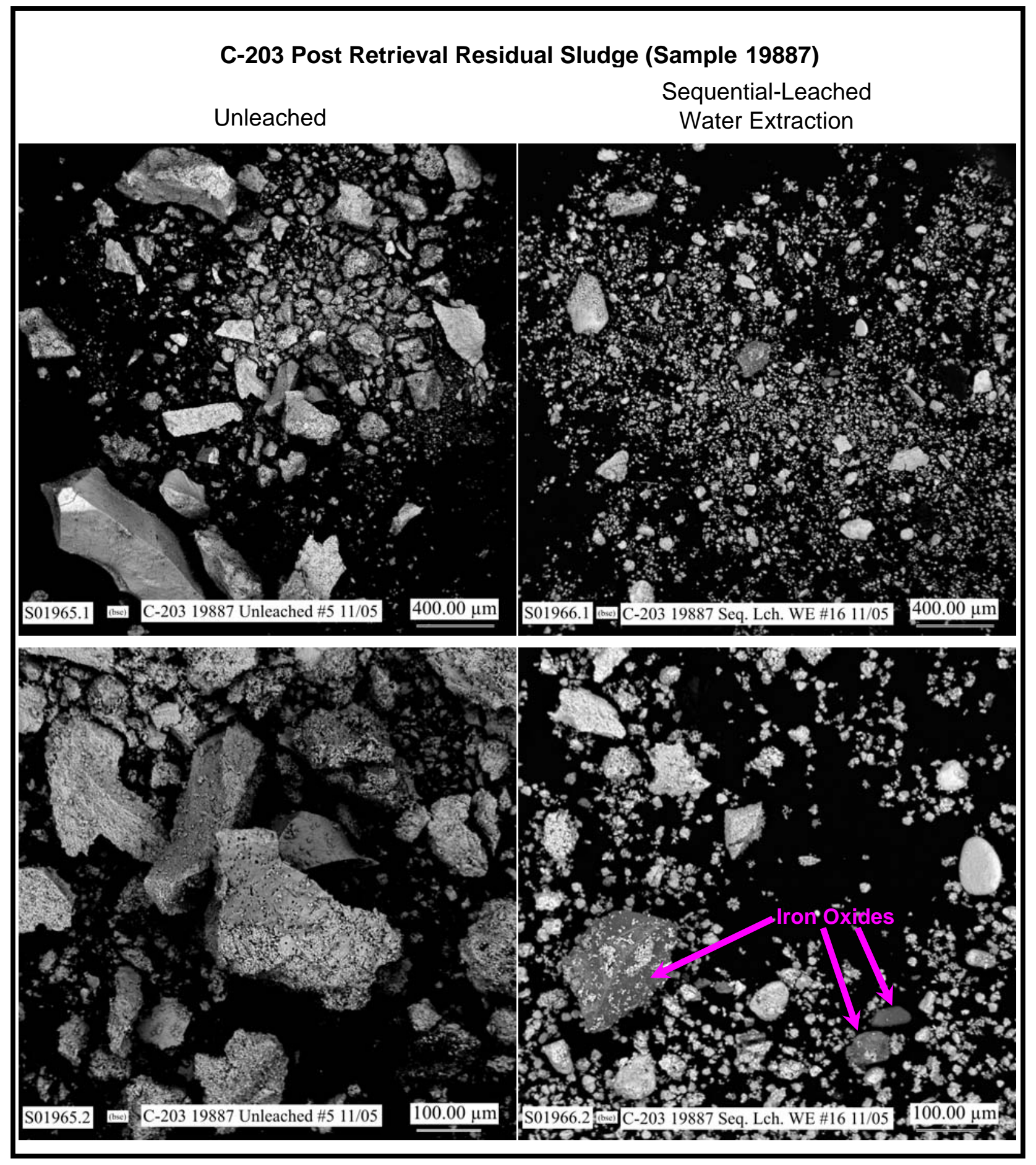

Figure 2.16. Backscattered Electron SEM Micrographs of Unleached (left side) and Sequential Double Deionized Water-Leached (right side) Samples of C-203 Residual Waste from Sample 19887 (from Deutsch et al. 2007c). The bottom row of micrographs shows at higher magnification the particles near the center of the corresponding left and right micrographs in the top row. 
presence of čejkaite $\left[\mathrm{Na}_{4}\left(\mathrm{UO}_{2}\right)\left(\mathrm{CO}_{3}\right)_{3}\right]$ as the primary crystalline phase and the possible presence of nitratine $\left(\mathrm{NaNO}_{3}\right)$ in the unleached (as-received) C-203 and C-204 pre-retrieval wastes (Krupka et al. 2006a; Deutsch et al. 2007b). As expected, neither čejkaite nor nitratine were identified in the SEM/EDS analyses of C-202 and C-203 residual waste because water was used to retrieve (remove) wastes from these tanks. Because these phases are highly soluble, they likely dissolved during final waste retrieval operations and thus were not present in samples of C-202 and C-203 residual waste studied by Deutsch et al. (2007c). However, the hexagonal, rod-like dissolution pits observed in some of the U-Na-C-O-P $\pm \mathrm{H}$ residual (post-retrieval) particles (see Figure 2.17) are consistent with the possible previous existence of hexagonal, acicular crystals of čejkaite (see small insert in upper right of Figure 2.17) in this post-retrieval residual waste.

The identification of the possible presence of goethite $[\alpha-\mathrm{FeO}(\mathrm{OH})]$, maghemite $\left(\gamma-\mathrm{Fe}_{2} \mathrm{O}_{3}\right)$, and the sodium uranates clarkeite $\left.\mathrm{Na}\left[\left(\mathrm{UO}_{2}\right) \mathrm{O}(\mathrm{OH})\right]\left(\mathrm{H}_{2} \mathrm{O}\right)_{0-1}\right]$ and/or $\mathrm{Na}_{2} \mathrm{U}_{2} \mathrm{O}_{7}$ in the water-leached pre-retrieval waste from tank C-203 (Deutsch et al. 2005, 2007b) is generally consistent with the iron oxide and uranium-sodium phases identified by SEM/EDS in the unleached and leached C-202 and C-203 residual waste samples. The pre-retrieval wastes from tanks C-203 and C-204 also contained a significant fraction of amorphous solids (Deutsch et al. 2007b) as did the C-202 and C-203 residual waste samples. Smooth, rounded, dense-looking particles of U-Na-C-O-P $\pm \mathrm{H}$ observed in the C-202 and C-203 residual waste samples were also present in the unleached and DDI water-leached C-203 pre-retrieval waste but not in unleached C-204 pre-retrieval waste sludge. The C-204 pre-retrieval waste also contained porous-looking particles or aggregates of submicron-size particles similar to the U-Na-C-O-P $\pm \mathrm{H}$ particle aggregates identified in the C-202 and C-203 residual waste samples.

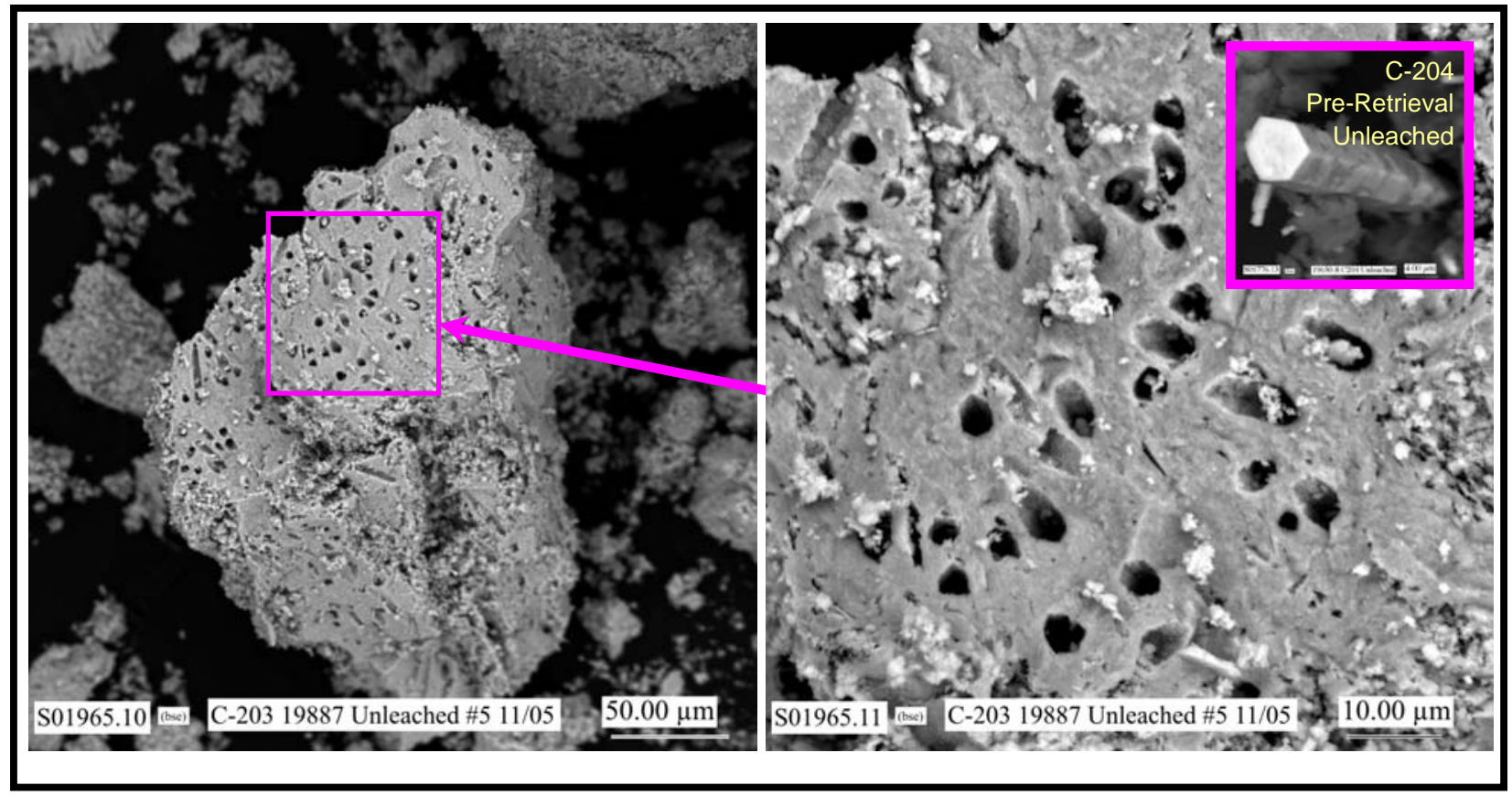

Figure 2.17. Particle of U-Na-C-O-P $\pm \mathrm{H}$ in the Unleached Sample of C-203 Residual Waste Showing Hexagonal, Rod-Like Dissolution Cavities (from Deutsch et al. 2007c). SEM micrograph in small upper right insert shows cross section of čejkaite crystal (from Deutsch et al. 2007b). 


\subsubsection{Other Issues and Characteristics of Residual Waste Solid Phases that Affect Contaminant Release}

The characterization studies of pre-retrieval and post retrieval (i.e., residual waste) tank waste samples conducted by Deutsch and co-workers as part of the PNNL Residual Tank Waste Characterization Project have revealed several morphological and chemical characteristics of these solids that are important to COI release from all SSTs (and DSTs) (see summary in Krupka et al. [2006a]). These characteristics influence the laboratory measurement of COI release from such wastes and are important to the refinement of conceptual models that may be used to simulate COI release.

The SEM analyses by Deutsch and co-workers typically have been completed by operating the SEM in the BSE mode. Scanning electron microscopy micrographs may be obtained as either high-resolution secondary electron (SE) or BSE images. Both SEM SE and BSE micrographs are obtained in exactly the same way. However, BSE emission intensity is a function of the element's atomic number (i.e., size of the nuclei), where the larger the atomic number, the brighter the signal. Thus, the BSE mode can be used to obtain an image that shows the different elements present in a solid. Figure 2.18 shows examples of SEM micrographs collected in both SE and BSE modes. Because many COIs are heavy elements, using the BSE signal has proved invaluable in rapidly distinguishing phases containing elements with large atomic numbers, such as iron, chromium, manganese, silver, mercury, and uranium within the complex assemblage of particles that make up each waste sample. Although operating in the SE mode might provide somewhat higher quality micrographs, discriminating different phases present in an SEM mount would be almost impractical and more time-consuming unless each phase had distinctly different morphologies, which is not the case for most phases identified in the Hanford SST wastes.

Solid residual wastes studied to date are generally made up of intergrown aggregates or conglomerates of different individual phases (identified above) at the tens of micrometers to submicron-size scale. Examples of this characteristic are shown in SEM BSE micrographs and element EDS distribution maps shown Figures 2.19 and 2.20. Because the samples studied to date by Deutsch and co-workers are composites of samples from multiple in-tank samplings or from several depths of a single in-tank sampling, the degree of intergrowth of particles in residual wastes remaining in a SST is likely significantly greater than that observed in the samples inspected by SEM. This aggregation affects the extent and rate at which ingressing pore water will contact the COI-containing phases within this multi-phase conglomerate and likely slow the rate at which COIs are leached from phases that are tightly intergrown within this conglomerate.

Some of the particles inspected by SEM/EDS are coated by phases having compositions different from that of the underlying particle(s). This characteristic can be seen in Figure 2.15 (see center of larger micrograph), Figures 2.19 and Figure 2.21. Because of their recalcitrant nature at near-neutral and basic $\mathrm{pH}$ conditions, coatings of iron oxides and aluminum oxyhydroxides would be expected to decrease the rate of dissolution of the underlying phases and any COIs they may contain. For coatings made of phases that are more soluble, the initial leach rates for these phases may be initially rapid until the coatings have totally dissolved from contact with ingressing pore water. The leach rates will then slow if the underlying phases are less soluble than the coatings. Release rate data collected for residual tank waste has to date relied primarily on single-contact and periodic replenishment leaching tests (see Section 4.0). To better understand the impact of such coatings on COI release rates, more advanced testing protocol, such as 


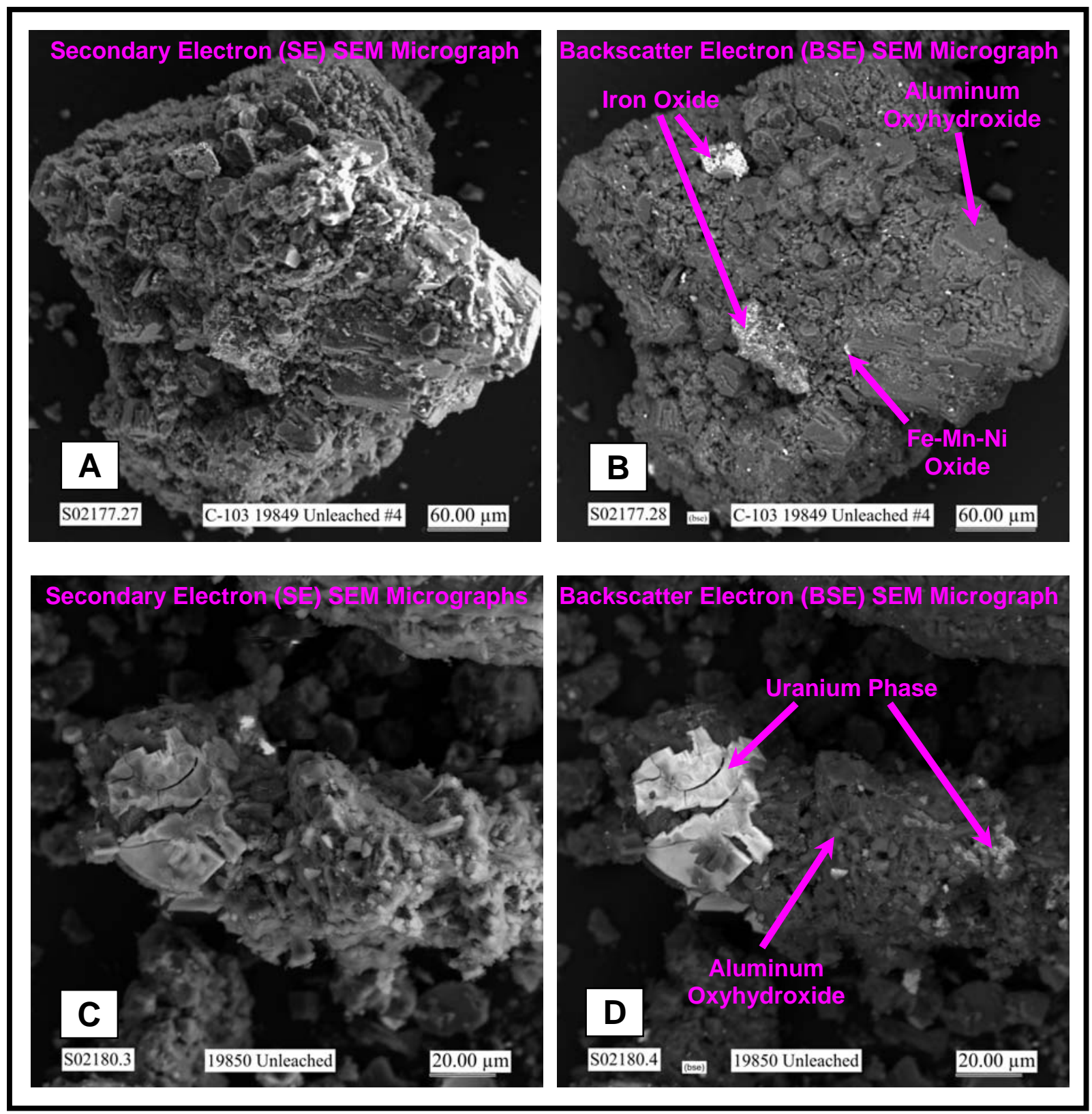

Figure 2.18. Secondary (A and C) and Backscattered Electron (B and D) Micrographs of Unleached C-103 Residual Waste (Samples 19849 [A and B] and 19850 [C and D]) (Cantrell et al. 2007a)

leach tests conducted using single-pass flow-through (SPFT) tests and/or stop-flow column techniques, are required to better quantify complex release kinetics for solids that are conglomerated and/or substantially coated with other solids.

Although not common, Deutsch and co-workers have also observed by SEM analysis pits or cavities in particles in several unleached and leached SST waste samples, which are thought to be preferential dissolution cavities. Examples of these pits or cavities are shown in the BSE micrographs in Figures 2.15 and 2.22 and are observed mostly in iron oxides such as those shown in Figure 2.22. These features 


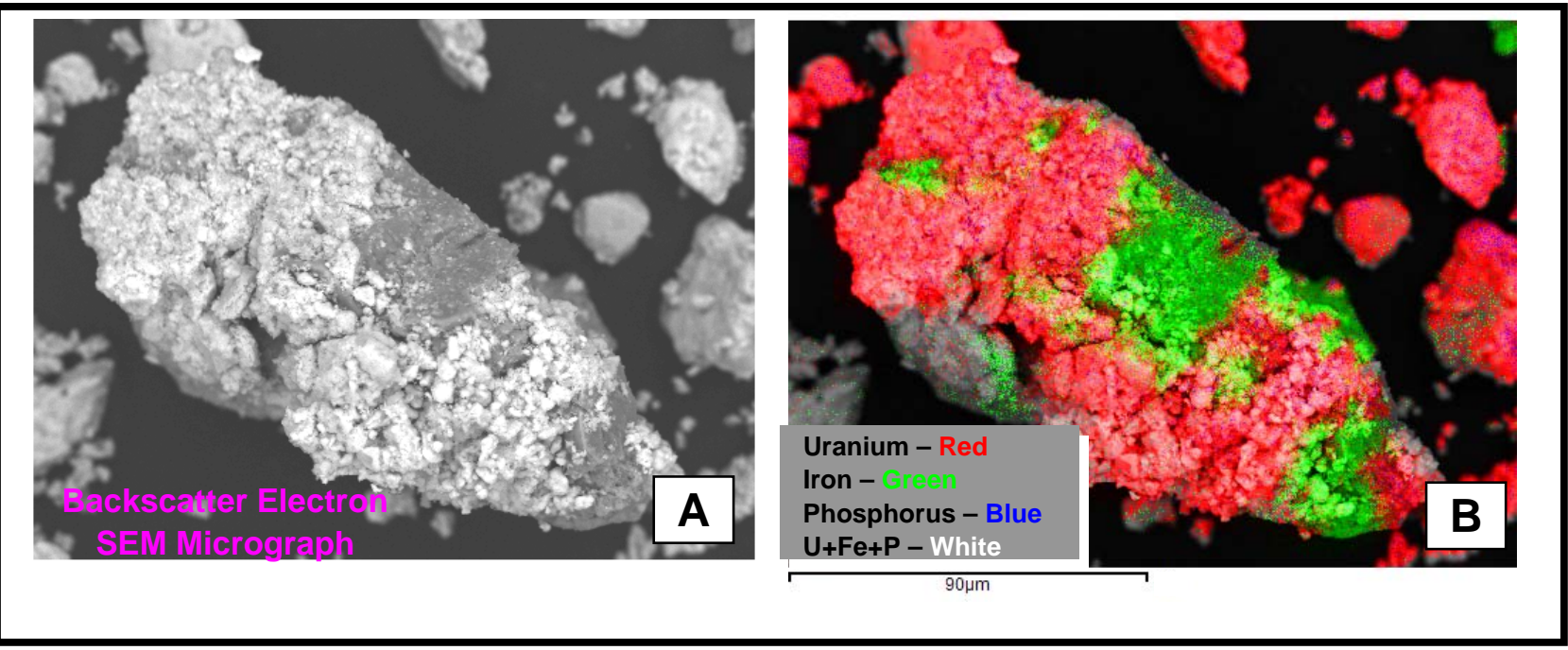

Figure 2.19. Backscattered Electron Micrograph and Multi-Element EDS Map for Aggregate of $\mathrm{U}-\mathrm{Na}-\mathrm{C}-\mathrm{O}-\mathrm{P} \pm \mathrm{H}$ and Iron Oxide Particles Present in Sequential-Leached Water Extraction Sample of C-203 Residual Waste (Sample 19961) (from Deutsch et al. 2007c)

might also be explained by the presence of another phase that contains lighter elements than the iron oxide matrix, which would cause their dark contrast in the BSE image (Krupka et al. 2006a). However, when imaged at higher magnification, these features appear to have depth, which is more consistent with at least some of them being dissolution cavities. The relatively smooth, round cavities shown in micrograph D in Figure 2.22 might alternatively be explained as artifacts of gas bubbles. These bubbles may have been entrained during the crystallization of the iron oxide matrix or generated later due to the accumulation of radiolytic gases or transient acid-base interactions. For this to occur, the iron oxides would have to precipitate very rapidly from a viscous slurry with possibly a high loading of waste mass above it to minimize the release of the gas bubbles. If the cavities shown in Figure 2.22 are due to preferential dissolution, then phases containing COIs may become encapsulated within the iron-oxide matrix and thus be partially isolated from ingressing pore water that might contact the residual tank wastes. Release of COIs from such assemblages would then be a function of the solubility and dissolution rates of these iron-oxide particles, which likely include co-precipitated trace metals (e.g., manganese, nickel, and chromium) and generally have low to very low solubilities and slow dissolution rates at near-neutral to basic $\mathrm{pH}$ values under oxic conditions.

Iron oxide particles have been identified by XRD and/or SEM/EDS in most of the tank waste samples studied by Deutsch and coworkers to date. The iron oxides appear to make up a very small fraction (probably less than a few percent) of most waste samples that have been characterized by XRD and SEM/EDS. However, because of their low solubility in aqueous solutions at near-neutral to basic $\mathrm{pH}$ values under oxic conditions and affinity for adsorbing and sequestering trace level contaminants, they may play a major role in release of the COIs from residual wastes remaining in the tanks. Hematite $\left(\mathrm{Fe}_{2} \mathrm{O}_{3}\right)$ was identified by bulk XRD in tank waste from AY-102 (Krupka et al. 2004), C-103 (Cantrell et al. 2007a) (possibly two iron phases), and C-106 (Deutsch et al. 2007a); and goethite $[\alpha-\mathrm{FeO}(\mathrm{OH})]$ and maghemite $\left(\gamma-\mathrm{Fe}_{2} \mathrm{O}_{3}\right)$ by synchrotron-based $\mu$ XRD in pre-retrieval tank waste from C-203 (Deutsch et al. 2005). Examples of iron oxide particles identified in tank waste samples are shown in SEM micrographs in Figures 2.10, 2.11, 2.15, 2.16, and 2.18 through 2.23. 


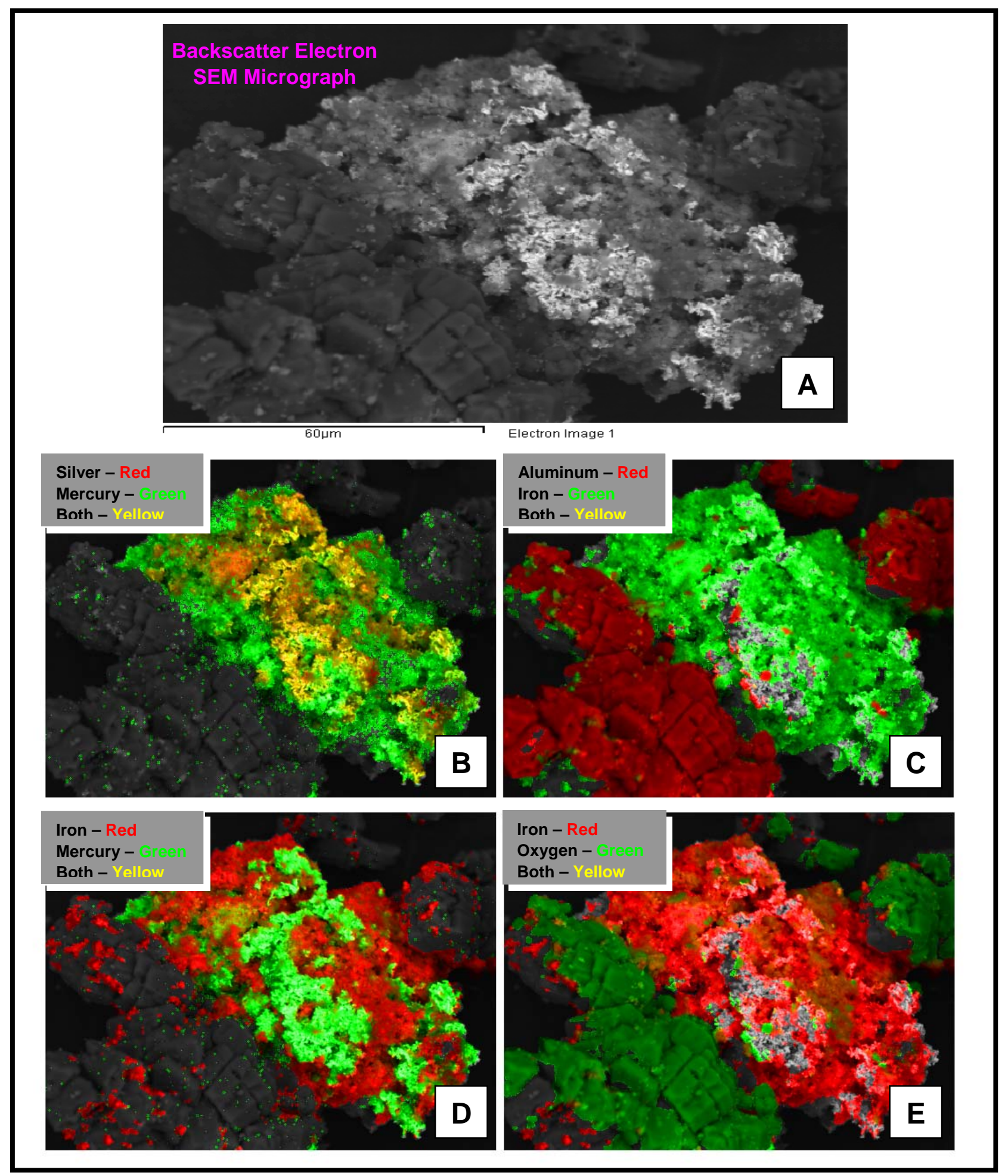

Figure 2.20. Backscattered Electron SEM Image (A) and Multi-Element EDS Maps (B through E) for a Particle Aggregate from the HF Extract of Tank C-106 Residual Waste (from Deutsch et al. 2007a) 


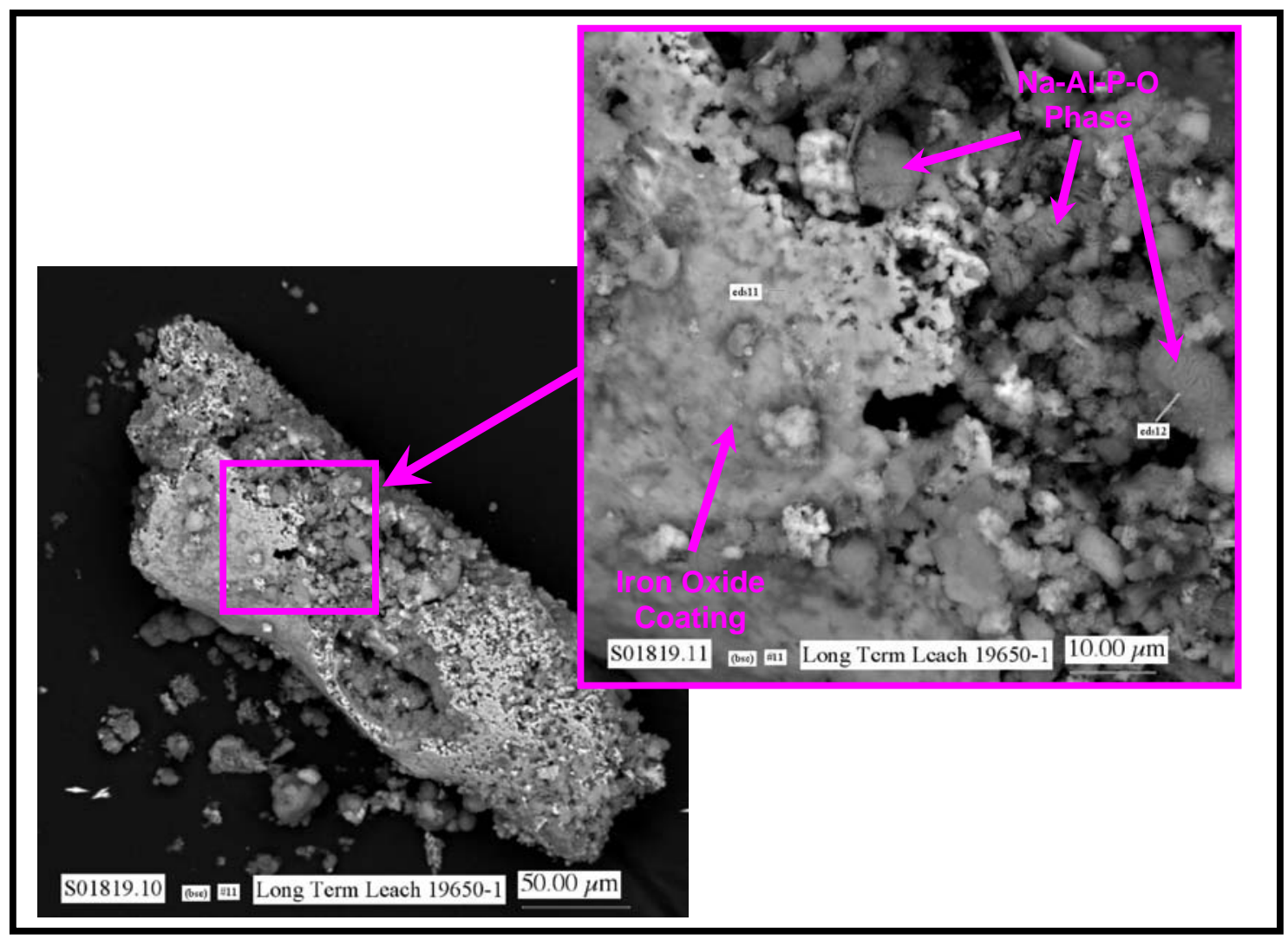

Figure 2.21. Backscattered Electron SEM Micrographs Showing Iron Oxide Coating on a Particle Conglomerate Observed in the Long-Term Leached Water Extraction Sample of C-204 Pre-Retrieval Tank Waste (Sample 19650) (from Krupka et al. 2006a; Deutsch et al. 2007b)

Energy-dispersive spectroscopy analyses of iron oxides present in tank waste samples studied by Deutsch and coworkers often indicate the presence of low concentrations of other transition metals, such as chromium, manganese, nickel, and sometimes uranium and technetium-99, in the iron oxide particles. As an example, Figure 2.23 shows typical EDS spectra for iron oxide particles identified by SEM/EDS in C-202 residual waste (Deutsch et al. 2007c). Technetium was identified by EDS in iron oxide/hydroxide particles in samples of unleached, DDI water-leached, and $\mathrm{CaCO}_{3}$-leached $\mathrm{C}-103$ residual waste. This is the first time in studies of pre-retrieval and post retrieval residual wastes from Hanford underground SSTs by PNNL's Residual Tank Waste Contaminant Release Project. Based on results from the selective extraction experiments, Cantrell et al. (2006) previously concluded that recalcitrant fraction of technetium-99 in C-203 and C-204 pre-retrieval tank wastes is incorporated into an iron oxide/ oxyhydroxide solid phase, and Deutsch and coworkers are currently assuming this conceptual model for the recalcitrant fraction of technetium-99 in the other tank wastes studied to date. Studies of pertechnetate and perrhenate (an analogue of pertechnetate) sorption and incorporation suggest that recalcitrant pertechnetate could also be associated with aluminum oxyhydroxides (Wakoff and Nagy 2004; Zhang et al 2000); however, our results to date do not support this hypothesis (Cantrell et al. 2006, 2007a; Deutsch et al. 2007b). As noted above, the release of COIs from iron oxides would be a function of the solubility and dissolution rates of these phases, which in general have low to very low solubilities and slow dissolution rates at near-neutral to basic $\mathrm{pH}$ values under oxic conditions. Deutsch and coworkers have already determined (see Figure 2.23) that some of the chromium in these tank wastes is coprecipitated within the structure of the iron oxides (Deutsch et al. 2007a, 2007c). 


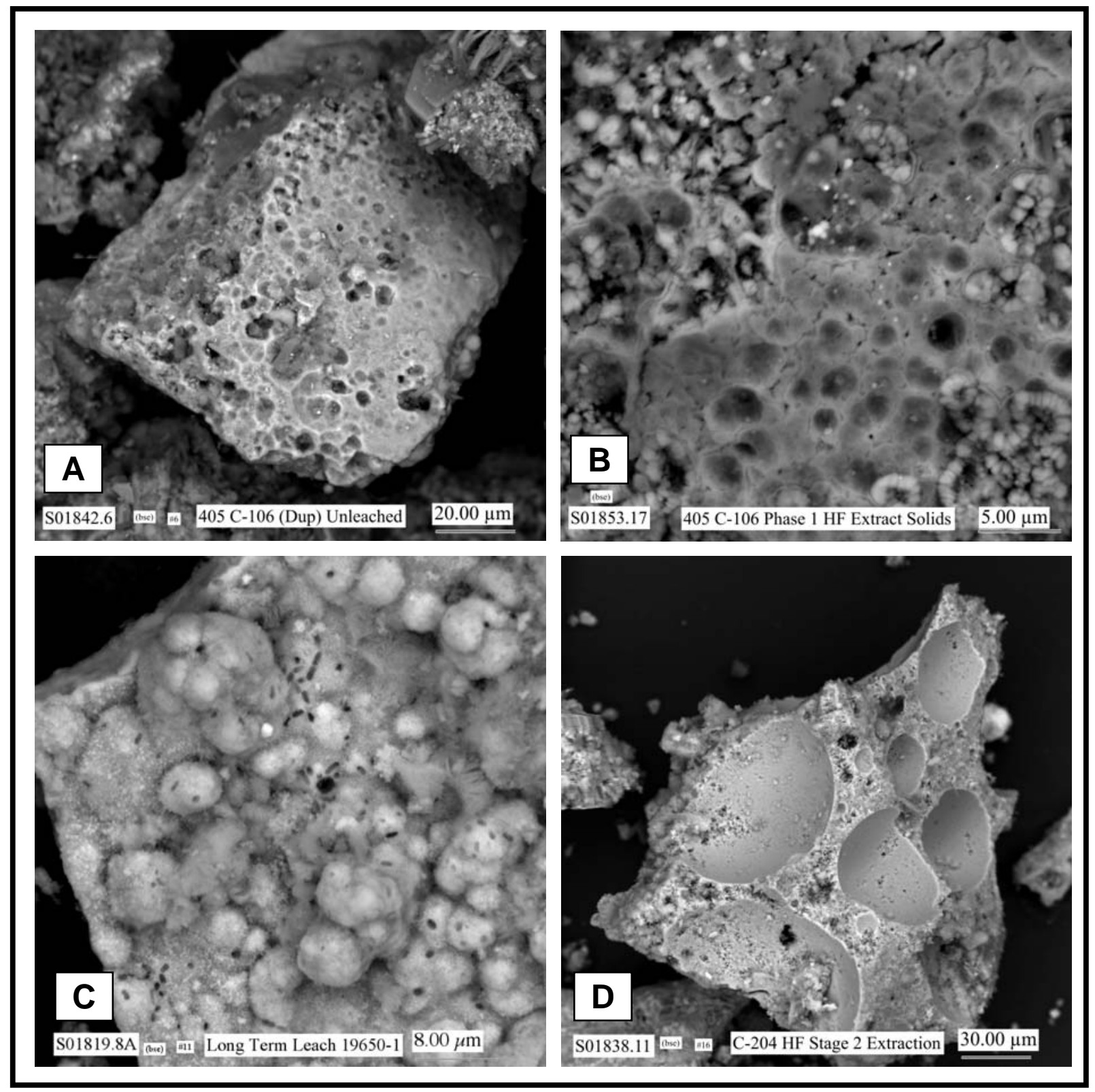

Figure 2.22. Backscattered Electron SEM Micrographs Showing Iron Oxides with Preferential Dissolution Cavities (A, B, and C) and Possibly Casts Formed from Entrapped Gas Bubbles (D). Micrographs A and B are from characterization studies of C-106 residual waste described in Deutsch et al. (2007a). Micrographs C and D are from characterization studies of C-204 pre-retrieval tank residual waste described in Deutsch et al. (2007b) and Krupka et al. (2007). 


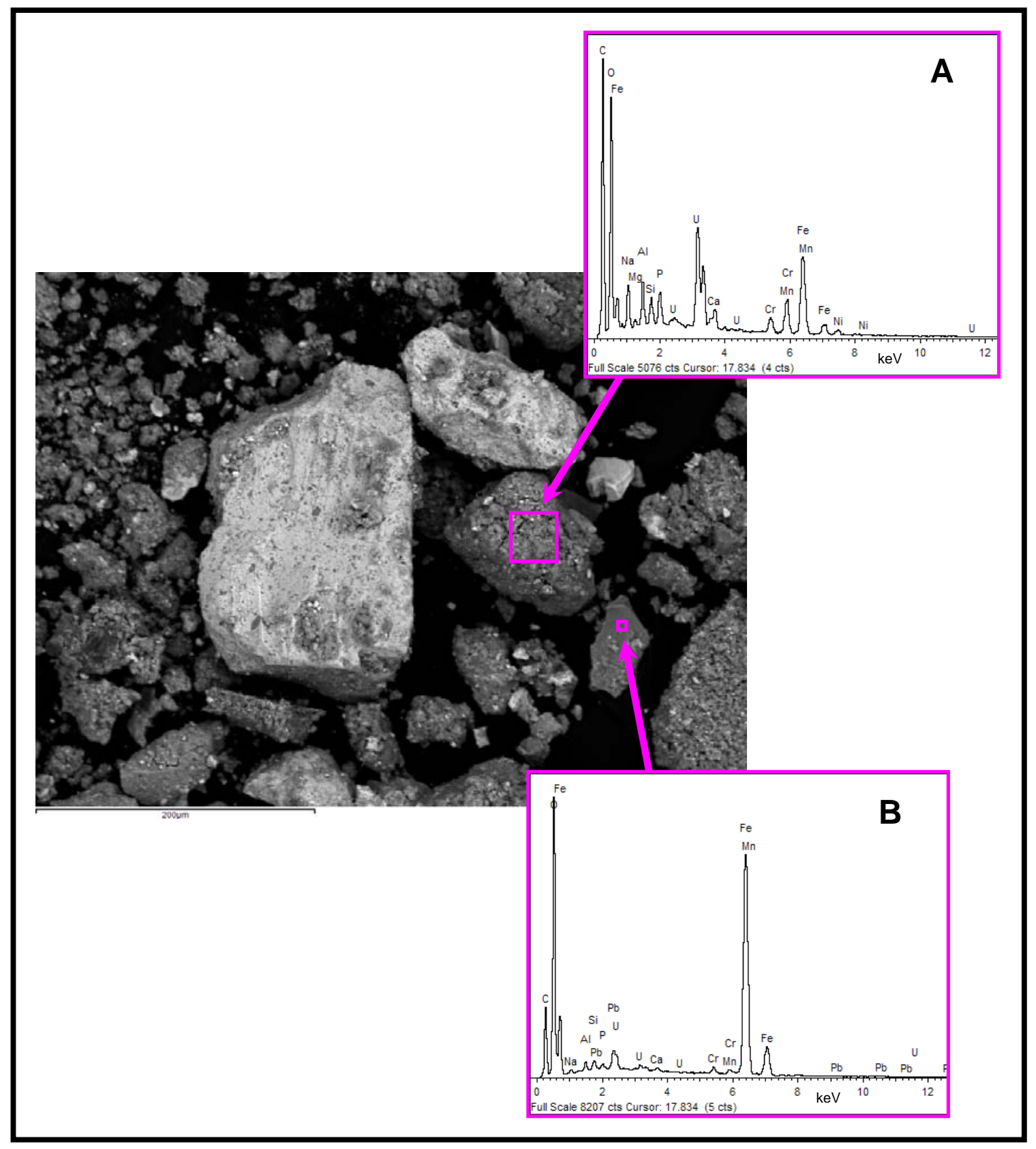

Figure 2.23. Typical EDS Spectra for Iron Oxide Particles Identified in C-202 Residual Waste (as Shown in the Backscattered Electron Micrograph) from the 1-Month Single-Contact Leached Water Extraction (from Deutsch et al. 2007c). Bright white particles, such as the large particles near center and above center, are an unidentified (possibly amorphous) uranium phase that also contains sodium, oxygen, phosphorus, and carbon. Spectrum A is an EDS analysis of a $\sim 35-\mu \mathrm{m}$-wide area of an iron oxide aggregate that also contains some small particles of this uranium phase. 
To confirm the hypothesis that COIs are trapped within/associated with iron oxide/oxyhydroxide solid phases, laboratory studies have been proposed to investigate the solubilities and crystallization history of iron oxides that are precipitated under controlled, tank-waste high-pH-high-sodium conditions in the presence of different concentrations of dissolved chromium or manganese. The solubilities of these precipitates would be quantified and phase characteristics of these solid reaction products analyzed by $\mathrm{XRD}, \mathrm{SEM} / \mathrm{EDS}$, and other techniques, to evaluate the influence of chromium and manganese on the crystallization and the dissolution rates of these coprecipitated iron oxides, including the possible formation of metastable amorphous iron oxides. A similar set of experiments and characterization studies would also be completed on iron oxides precipitated under the same tank-waste conditions in the presence of different concentrations of technetium-99. The goal of these later experiments would be to determine if coprecipitation of technetium-99 in iron oxides is possible and measure the rates of release for technetium-99 from such coprecipitated iron oxides.

Scanning electron microscopy studies completed by Deutsch and coworkers to date have shown that the size of particles of individual phases or within a conglomerate of phases ranges from tens of micrometers to submicrometer in size. This size range is readily apparent from the SEM micrographs presented in this section. Because of limitations of the instrumentation (and in some respects, the samples themselves) used for the SEM/ EDS analyses of highly radioactive waste samples studied by Deutsch and coworkers, quality SEM images of particles at the submicrometer size are not possible. Moreover, XRD studies, such as in Deutsch et al. (2007b; 2007c), also suggest that some tank waste samples contain a significant fraction of amorphous phases. Therefore, there is a general absence of information regarding the composition, crystallinity, and morphology of waste particles at the submicrometer-nanometer scale, and what complexities exist at this size scale that may affect release of individual contaminants. Studies have been proposed to evaluate the technical feasibility, sample preparation requirements, and associated costs of using "hot" transmission electron microscopy (TEM) instrumentation available at PNNL to characterize radioactive, dispersible SST residual waste. To date, TEM has not been tried because of other project priorities and potential safety and cost issues thought to be associated with preparation and analysis of radioactive residual waste by TEM. Although TEM analysis would provide useful structural and chemical information for tank waste particles at the submicrometer-nanometer scale, the preparation and analysis costs per TEM sample are thought to be considerably higher than the other Tier 1 and 2 analyses conducted as part of the PNNL Residual Tank Waste Characterization Project. 


\subsection{Geochemistry of Contaminants of Interest in Closed Single-Shell Tanks}

This section describes the type of contaminants present in the typical residual waste, with an emphasis on the COIs from the perspective of potential long-term risk to groundwater quality. The anticipated geochemical conditions likely present in the tanks after closure are described, and the geochemistry of the COIs from the standpoint of release from the tanks is discussed.

\subsection{Contaminants of Interest Selection Process}

Residual waste in the SSTs contains a wide range of potential contaminants including metals, radionuclides, and some organic compounds. A complete accounting of the chemical concentration of the residual waste in each tank can be found in the TWINS database, which tracks more than 25 chemical and 46 radionuclide components. From a long-term perspective of risk to groundwater from the residual waste, it has been established that only a few of the constituents in the waste are of interest (DOE ORP 2006). The most important attributes that make a COI from a long-term risk perspective are

- amount of material (inventory) in tank and how fast it is released

- long half-life for radionuclides

- rate at which moisture flows through the system

- degree to which contaminants interact with the sediment surrounding and below the tank

- quantity of groundwater into which the contaminants move

- restrictiveness of the regulatory requirements.

The COIs in residual tank waste from the standpoint of long-term risk to groundwater are uranium, technetium-99, iodine-129, chromium, and nitrate (DOE ORP 2006). These contaminants are of interest because they have the potential to be released from the waste, have long half-lives for those that are radioactive, might affect the underlying groundwater at a concentration that could be of risk to a future groundwater user, and, for several, are mobile in the vadose zone because they do not adsorb significantly to the sediments.

The primary geochemical processes that affect the release of contaminants from the residual waste and the migration of these contaminants are formation of strong aqueous complexes containing the contaminant, dissolution/precipitation of minerals containing the contaminant, and adsorption/desorption of contaminants to the surfaces of solids. Adsorbing solids may occur in the residual waste, materials (e.g., cement) added to the emptied tanks, and corrosion products on the carbon steel liner of a tank. The solubility of minerals and the affinity of adsorbents for contaminants are functions of a large number of geochemical variables; the primary ones are $\mathrm{pH}$, redox potential, solution speciation, ionic strength, and competition for adsorption sites. The importance of these variables to the geochemical processes that affect contaminant release are discussed in this section, along with the anticipated environmental conditions in the closed SSTs. 


\subsection{Geochemical Conditions in Closed Single-Shell Tanks}

This section discusses the general geochemistry and sorption ${ }^{(a)}$ reactions that might affect these COIs present in residual waste in the SSTs. Tank residual waste is defined here as that waste that remains in the tank after all waste retrieval campaigns have been completed. The important geochemical reactions affecting the mobility of these COIs after they are released from the immediate environment of the SSTs to the subsurface environment are reviewed in detail in Cantrell et al. (2007b). When the information is relevant to the behavior of COIs in leachates from residual tank waste, text from the COI geochemistry reviews in Cantrell et al. (2007b) is repeated in this data package to keep the summaries comprehensive within each data package. The occurrence and mineralogical association of these COIs in residual tank waste and the mechanisms affecting their release from residual waste are discussed in detail in Sections 4 and 5, respectively.

The following summaries focus on the chemistries of the following three types of leachants resulting from contact with vadose zone pore water or possible tank filling solids: 1) leachant resulting from ingressing dilute, vadose zone pore water $(\mathrm{pH} \sim 8)$; 2) $\mathrm{Ca}(\mathrm{OH})_{2}$-saturated $(\mathrm{pH} \sim 11-12)$ leachant; and 3) $\mathrm{CaCO}_{3}$-saturated $\left(\mathrm{pH} \sim 8\right.$-9) leachant. The $\mathrm{Ca}(\mathrm{OH})_{2}$ - and $\mathrm{CaCO}_{3}$-saturated leachants represent the chemical and $\mathrm{pH}$ conditions of pore fluids associated with fresh and aged (carbonated) cements, respectively. Because calcite $\left(\mathrm{CaCO}_{3}\right)$ occurs in various amounts in the native vadose sediments, the $\mathrm{CaCO}_{3}$-saturated solution also represents the conditions expected for a leachant resulting from an ingressing calcite-equilibrated pore water that reacts with residual tank waste. The different chemistries of the leachants will produce different COI concentrations in leachates resulting from contact of the leachants with the residual tank wastes. Consequently, the composition of the leachant and its chemical evolution are important factors in developing contaminant release models for closed tanks.

\subsubsection{Role of Cementitious Materials}

One closure method under consideration for the Hanford tanks after waste retrieval is to fill them with a cement grout to maintain the structural integrity of the tank. Fresh cement/grout will contain pore fluids that have high $\mathrm{pH}$ values (buffered near $\mathrm{pH} \sim 12.4$ by the dissolution of portlandite $\left[\mathrm{Ca}(\mathrm{OH})_{2}\right]$ in the cement) and high concentrations of soluble salts. Infiltration will enter the cement/grout initially through pores and then through cracks as the grout ages. At the outset, the most readily soluble salts will leach out, lowering the dissolved concentrations of these salts and the $\mathrm{pH}$ within the cement grout pore fluids (if the dissolved salts contain high sodium and potassium concentrations from cement ingredients). In addition, carbon dioxide will interact with the cement as air moves into the pores/fractures and as water with dissolved $\mathrm{CO}_{2}$ migrates through the grout. Carbon dioxide will also react with portlandite in the cement to precipitate calcite $\left(\mathrm{CaCO}_{3}\right)$ and lower the $\mathrm{pH}$.

$$
\mathrm{Ca}(\mathrm{OH})_{2}+2 \mathrm{CO}_{2} \rightarrow \mathrm{CaCO}_{3}+\mathrm{HCO}_{3}^{-}+\mathrm{H}^{+}
$$

(a) Throughout this section, sorption is used as a generic term devoid of mechanism and to describe the partitioning of dissolved aqueous-phase constituents to a solid phase. When a COI is associated with solid material, however, it is usually not known if the COI is adsorbed onto the surface of the solid, absorbed into the structure of the solid, precipitated as a three-dimensional molecular structure on the surface of the solid, or partitioned into organic matter (Sposito 1989). The term sorption encompasses all of the above processes. 
Carbonation and calcite precipitation are considered the most common chemical reactions influencing the performance of cement-based materials in natural systems. In addition to the formation of calcite from $\mathrm{Ca}(\mathrm{OH})_{2}$, calcite will form also from carbonation of calcium silicate hydrogel $(\mathrm{CSH})$, which typically constitutes $40 \%$ to $50 \%$ of an ordinary portland cement (OPC). During this stage of cement aging, $\mathrm{CO}_{2}(\mathrm{aq})$ reacts with the remaining $\mathrm{CSH}(\mathrm{gel})$ to form additional $\mathrm{CaCO}_{3}(\mathrm{~s})$, silica gel, and water.

$$
\mathrm{CSH}(\text { gel })+\mathrm{CO}_{2}(\mathrm{aq}) \rightarrow \mathrm{CaCO}_{3}(\mathrm{~s})+\mathrm{SiO}_{2}(\text { gel })+\mathrm{H}_{2} \mathrm{O}
$$

Eventually, the solutions in contact with aged cement grout come into equilibrium with calcite at a $\mathrm{pH}$ of $\sim 8.3$ as the surfaces of the cement solids become coated with this mineral. Even after this happens, the $\mathrm{CSH}$ gel will, however, also continue to dissolve and result in elevated concentrations of dissolved silica. Elevated silica concentrations can, in turn, result in the precipitation of uranyl-silicate minerals, such as boltwoodite $\left[(\mathrm{K}, \mathrm{Na})\left(\mathrm{UO}_{2}\right) \mathrm{SiO}_{3}(\mathrm{OH}) \cdot 1.5 \mathrm{H}_{2} \mathrm{O}\right]$, which will lower uranium solubilities somewhat below that for silica-free leach systems. Elevated dissolved silica concentrations are not currently considered in PNNL's cement-stimulant $\mathrm{CaCO}_{3}$-leach test protocol but will be considered in future $\mathrm{CaCO}_{3}$ leach testing and source-term thermodynamic-based calculations.

\subsubsection{Role of Organic Complexants}

Various chemical separation processes were used at the Hanford Site to extract and process plutonium from spent nuclear fuel and to remove other elements for special uses or to lower the heat generation properties of the residual waste. For example, strontium-90 and cesium-137 were removed from some tank wastes so that self-boiling issues could be alleviated. Organic extraction solvents and organic complexants were used in some of these separations processes. It is assumed that tank waste retrieval processes will remove most of the soluble complexants, dramatically reducing their concentrations in the tank residual waste and, as a result, their potential for mobilizing contaminants. In addition, many of the organic complexants used in the waste separations processes have been destroyed or degraded during storage in the tanks by heat, radiolysis, and caustic interactions (Grant et al. 1996; Sharma et al. 1998). Finally, given the general absence of data for the concentrations of such organic compounds in leachates from tank residual waste and limited availability of thermodynamic constants for aqueous species containing the COIs and these organic complexants, these extraction solvents and organic complexants are not considered in the individual discussions of geochemical processes and aqueous speciation and solubility calculations presented below for each COI.

The principal extraction solvents used at the Hanford Site were tributyl phosphate (TBP) and mixtures of normal paraffinic hydrocarbons (NPHs). Tributyl phosphate s the extraction agent, while NPHs are used as diluents and do not interact with metal ions. Tributyl phosphate is a relatively weak extractant, is slightly soluble in water, and requires contact with a concentrated salt or acid solution for effective extraction (Schulz et al. 1984). More important for existing tank conditions, carbonate complexation (discussed in individual COI reviews below) will dominate the speciation of actinides in solution (Lundqvist 1982; Cantrell and Byrne 1987). As a result of these factors, TBP is not expected to produce significant mobilization of actinide elements or other contaminants from residual tank waste. Dibutyl phosphate (DBP) is a degradation product of TBP and can form somewhat stronger complexes for some metal ions than TBP (Schulz and Navratil 1984). In addition, DBP is soluble in water ( $>9 \mathrm{M}$; Barney 1996). Analyses of tank waste containing significant concentrations of TBP show relatively small amounts of DBP. For example, the TBP concentration measured in tank C-204 waste was 330,000 $\mu \mathrm{g} / \mathrm{g}$, while the DBP concentration was $2,000 \mu \mathrm{g} / \mathrm{g}$ (Conner 1996). Because DBP is soluble in both water and 
TBP, it is unclear if DBP has the potential to mobilize contaminants from residual tank waste. As a result of these observations, TBP is not considered to have significant potential for mobilizing actinides from residual tank waste. The potential for contaminant mobilization by DBP is less certain.

Other processes used in the past at Hanford used large quantities of organic complexants, such as glycolic acid, citric acid, hydroxyethylethylenediaminetriacetic acid (HEDTA), and ethylenediaminetetraacetic acid (EDTA) (Allen 1976; Meacham et al. 1996). In addition to these compounds, complexants such as nitrilotriacetic acid (NTA), di (2-ethylhexyl)phosphoric acid, and oxalic acid also were used. The quantity of these complexants used was relatively small and not well quantified (Meacham et al. 1996). In addition to the complexing agents themselves, fragments of complexing agents have formed as the result of partial degradation caused by the high radiation field and elevated temperatures in the tanks. Analysis of complexants and complexant fragments in samples collected from tanks AX-102, C-104, BX-104, C-201, and C-202 identified and quantified the concentrations of glycolic acid, citric acid, HEDTA, EDTA, NTA, and oxalate, as well as formate, iminodiacetic acid (IDA), ethylenediaminetriacetate (ED3A), and symmetric ethylenediaminediacetic acid (s-EDDA) (Campbell et al. 1998).

A number of factors will interact to determine the significance of these complexants with regard to their ability to mobilize contaminants from tank residual waste. These include the stability or strength of the complexes that are formed (the size of the stability constant); the concentrations of the complexants; competition with other major ions that form strong complexes with the complexants, such as iron and aluminum; disassociation of the complexes upon dilution (Le Chatelier's principle); and adsorption and precipitation of the complexants and organo-metallic complexes.

EDTA, HEDTA, NTA, ED3A, citric acid, oxalate, IDA, and s-EDDA all have relatively high stability constants for multivalent cations such as actinides and have the highest potential for mobilizing multivalent metal contaminants. Glycolate and formate form relatively weak complexes and are not regarded as having significant potential for mobilizing multivalent metal contaminants. With the exception of oxalate, most of these complexants are quite soluble. For example, the solubilities of glycolate, formate, citric, NTA, EDTA, and HEDTA range from 0.6 to $9.8 \mathrm{M}$ (43 grams of carbon per liter [g C/L] to $118 \mathrm{~g} \mathrm{C} / \mathrm{L}$ ), depending on the compound, sodium hydroxide concentration, and temperature (Barney 1996). High concentrations of these complexants have significant potential for mobilizing certain contaminants from tank residual waste that are normally immobile in dilute aqueous systems. These include Cr(III) and the actinides of interest. Although relatively high concentrations of complexants have been measured in some tank wastes (more often in DSTs), it is likely that tank waste retrieval processes will remove most of the soluble complexants and thus reduce their potential for mobilizing contaminants.

\subsubsection{Potential Adsorbates}

The following geochemical reviews will focus on adsorption of COIs at $\mathrm{pH}$ values between 8 to 13 onto iron-oxide/hydroxide corrosion products that may exist on the carbon steel tank liners and cementitious materials that have been added to the emptied tanks or are present in the tank outer shell. Adsorption of COIs also may occur onto solids in the tank residual waste. However, little can be said about the adsorption reactions with these solids because there is limited solids characterization data available for Hanford SST residual waste. For those solids identified in the small number of studies conducted to date of tank residual waste, such as the studies summarized in Section 2 of this data package 
and described in more detail in the cited reports by Deutsch and colleagues at PNNL, there is essentially no adsorption data for COIs on these solids at the $\mathrm{pH}$ values of $\sim 8$ to 12.5 expected for leachates from tank residual wastes.

\subsection{Calculation of Eh-pH Diagrams}

The $\mathrm{pH}$ and Eh conditions and associated aqueous complexation and solubility reactions are key parameters in understanding the environmental behavior of COIs. To show the impact of these parameters on the geochemistry of the COIs, the distributions of dominant aqueous species and potential solubility controls for the environmentally important oxidation states for COIs were calculated as a function of $\mathrm{pH}$ and Eh using computer modeling based on equilibrium thermodynamic principles. The results of these speciation and solubility calculations are presented graphically in Sections 3.4 through 3.8 for each COI as Eh-pH (or Pourbaix) diagrams. The theory behind the calculation of Eh-pH predominance diagrams is discussed by Garrels and Christ (1965), Langmuir (1997), Nordstrom and Munoz (1985), and others. The Eh-pH diagrams were calculated at $25^{\circ} \mathrm{C}(298 \mathrm{~K})$ and 1 atm pressure using The Geochemist's Workbench (Version 6.0.4) software package and the expanded thermodynamic database file "thermo.com.V8.R6+.dat" provided with the software package. The Lawrence Livermore National Laboratory (LLNL) developed the thermodynamic database file originally for use with the EQ3/6 geochemical model. This database includes thermodynamic values for uranium species given in the extensive review by Grenthe et al. (1992). However, the database file does not have the most up-to-date constants for some technetium aqueous species and solids. The database file predates publication of the extensive reviews of thermodynamic values for technetium species by Rard et al. (1999).

The Eh-pH diagrams presented in this section are meant for demonstration purposes only, to show the general aspects of the dominant aqueous species and potential solubility controls for each COI with respect to $\mathrm{pH}$, Eh, and potentially important complexing anions. The regions colored in blue and tan, respectively, show regions dominated by an aqueous species or oversaturated with respect the indicated solid. The gray-shaded area in each Eh-pH diagram shows the $\mathrm{pH}$ range of primary interest for leachates from tank residual waste. Each Eh-pH diagram in the following summaries contains dashed black lines from coordinates (Eh $1.2 \mathrm{~V}-\mathrm{pH}$ 0) to (Eh $0.4 \mathrm{~V}-\mathrm{pH} 14)$ and from (Eh $0.0 \mathrm{~V}-\mathrm{pH} 0$ to $\mathrm{Eh}-0.8 \mathrm{~V}-\mathrm{pH} 14)$ that represent the Eh-pH boundaries for the dissociation of water to its gaseous components at $25^{\circ} \mathrm{C}$ and $1 \mathrm{~atm}$ pressure. At Eh-pH values above the upper black dashed line, water breaks down to oxygen gas. At Eh-pH values below the lower black dashed line, water breaks down to hydrogen gas. The redox conditions for essentially all environmental systems occur in the region within these water-stability limits.

Because there is no estimated composition for a "generic" leachate from SST residual wastes, the maximum concentrations (Table 3.1) of COIs, potential complexing anions, and other key constituents (e.g., dissolved sodium) measured in leachates from the 1-month single-contact DDI, $\mathrm{Ca}(\mathrm{OH})_{2}$, and $\mathrm{CaCO}_{3}$ extractions of residual waste from tanks C-202 and C-203 given in Deutsch et al. (2007c) were used to calculate the Eh-pH diagrams.

The Geochemist's Workbench (Version 6.0.4) software package calculates Eh-pH diagrams for the speciation of a dissolved element (e.g., uranium) using input values of "activity," which is often referred to as an "effective concentration" (Krauskopf 1979), for the concentration of the element of interest. The following Eh-pH diagrams are used to display the stability fields for the dominant aqueous species and potential solubility-controlling solid(s) for each COI based on the available thermodynamic database. 
Table 3.1. Concentrations of Dissolved COIs and Other Potentially Important Cationic and Anionic Constituents Used to Calculate the Eh-pH Diagrams. The listed concentrations are based on maximum values measured in leachates from the 1-month single-contact DDI, $\mathrm{Ca}(\mathrm{OH})_{2}$, and $\mathrm{CaCO}_{3}$ extractions of residual waste from tanks C-202 and C-203 reported by Deutsch et al. (2007c).

\begin{tabular}{|c|c|c|c|c|c|}
\hline \multicolumn{2}{|c|}{ COIs } & \multicolumn{2}{|c|}{ Other Cations of Interest } & \multirow{2}{*}{\multicolumn{2}{|c|}{ Other Anions of Interest }} \\
\hline \multirow[b]{2}{*}{$\mathrm{Tc}$} & \multirow{2}{*}{$\frac{\mathrm{mol} / \mathrm{L}}{1.62 \times 10^{-9}}$} & \multirow[b]{2}{*}{$\mathrm{Al}$} & \multirow{2}{*}{$\begin{array}{c}\mathrm{mol} / \mathrm{L} \\
8.38 \times 10^{-4} \\
\end{array}$} & & \\
\hline & & & & $\mathrm{CO}_{3}{ }^{2-(\mathrm{a})}$ & $10^{-3.5} \mathrm{~atm}^{(\mathrm{a})}$ \\
\hline $\mathrm{U}$ & $2.12 \times 10^{-3}$ & $\mathrm{Ca}$ & $1.18 \times 10^{-3}$ & & $\mathrm{~mol} / \mathrm{L}$ \\
\hline $\mathrm{I}$ & $7.56 \times 10^{-9}$ & $\mathrm{~K}$ & $6.11 \times 10^{-5}$ & $\mathrm{SO}_{4}{ }^{2-}$ & $5.03 \times 10^{-5}$ \\
\hline $\mathrm{Pu}$ & $3.12 \times 10^{-6}$ & $\mathrm{Mg}$ & $2.06 \times 10^{-4}$ & $\mathrm{PO}_{4}^{3-}$ & $3.52 \times 10^{-3}$ \\
\hline $\mathrm{Np}$ & $3.42 \times 10^{-9}$ & $\mathrm{Na}$ & $2.05 \times 10^{-2}$ & $\mathrm{Cl}-$ & $4.45 \times 10^{-5}$ \\
\hline $\mathrm{Am}$ & $3.32 \times 10^{-11}$ & $\mathrm{Si}$ & Not detected & $\mathrm{F}-$ & $2.58 \times 10^{-3}$ \\
\hline $\mathrm{Cr}$ & $3.16 \times 10^{-4}$ & & & & \\
\hline $\mathrm{NO}_{3}^{-}$ & $1.63 \times 10^{-3}$ & & & & \\
\hline \multicolumn{6}{|c|}{$\begin{array}{l}\text { (a) The Eh-pH diagrams were calculated assuming that the concentration of dissolved carbonate/ } \\
\text { bicarbonate in the leachants was controlled by equilibrium with atmospheric } \mathrm{CO}_{2} \text { at } 10^{-3.5} \mathrm{~atm}\end{array}$} \\
\hline
\end{tabular}

Therefore, the concentrations of COIs, cations, and anions (except as discussed below for dissolved bicarbonate/carbonate) in Table 3.1 were used for the sake of simplicity as "activity" input values for the Eh-pH speciation calculations.

The Eh-pH diagrams were calculated assuming that the concentration of dissolved carbonate/ bicarbonate was controlled by equilibrium with atmospheric $\mathrm{CO}_{2}$ at $10^{-3.5}$ atm (Table 3.1). Limited sources of inorganic carbon should exist in the remaining residual waste, and, in a semiarid, organic-poor soil typical of the Hanford Site, the assumption that the partial pressure of $\mathrm{CO}_{2}$ in the soil is at the atmospheric level is considered reasonable. Carbonate/bicarbonate concentrations calculated based on equilibrium with atmospheric $\mathrm{CO}_{2}$ are similar to or greater than those reported for the leachates from the 1-month single-contact DDI water, $\mathrm{Ca}(\mathrm{OH})_{2}$, and $\mathrm{CaCO}_{3}$ extractions of residual waste from tanks C-202 and $\mathrm{C}-203$. It should be noted that the partial pressure of $\mathrm{CO}_{2}$ may be higher outside a SST in the vadose zone environment. If so, this would further increase the importance of carbonate/bicarbonate equilibrium in the geochemical behavior of certain COIs. It is not known if this higher partial pressure of $\mathrm{CO}_{2}$ would extend to the interior of a SST.

As noted in Deutsch et al. (2007c), the 1-month DDI water extracts from the C-203 residual wastes contained between 200 to $350 \mathrm{mg} / \mathrm{L}$ phosphate. The phosphate in these extracts likely came from dissolution of tributyl phosphate wastes present in the $\mathrm{C}-200$ series tanks. Tributyl phosphate was used as an organic solvent in several separations processes at the Hanford Site. Because the available thermodynamic data for uranium and the actinides considered in this review predict phosphate complexes to dominate, especially at these high phosphate concentrations, over a large $\mathrm{pH}$ range and because not all tanks contain such high phosphate concentrations, Eh-pH diagrams are presented for solution compositions assuming a concentration of 0 (total absence) and $3.52 \times 10^{-3} \mathrm{M} \mathrm{(334} \mathrm{mg/L)} \mathrm{(Table} \mathrm{3.1)}$ dissolved phosphate.

Aqueous speciation calculations are usually not sensitive to the concentration selected for COI except for conditions that may lead to the formation of polynuclear species. Such conditions (i.e., large 
concentrations of a dissolved cationic COI) are not expected to apply to the reviews discussed below. However, when the solubility calculations are affected by the concentration selected for the COI, it will be noted in the individual COI geochemistry summaries that follow.

Because thermodynamic data typically do not have the resolution to distinguish among different isotopic forms of radionuclide-containing aqueous species or solids, geochemical modeling calculations do not provide any information on the distribution of the different radionuclide isotopes present in the aqueous, gaseous, or associated solid phases. However, in most situations, it is expected that isotopes of a particular element will react in the same manner.

\subsection{Uranium}

Uranium (U) (atomic number 92) is a member of the actinide series of elements. The uranium isotopes of primary interest to waste disposal and site remediation activities at the Hanford Site include uranium-235 and uranium-238. The half-lives $\left(t_{1 / 2}\right)$ of uranium-235 and uranium-238 are $7.04 \times 10^{8}$ and $4.468 \times 10^{9}$ years, respectively (Tuli 2004). The geochemical behavior of uranium has been reviewed by Langmuir (1978) and updated in Langmuir (1997). An extensive compilation of detailed reviews on the mineralogical, geochemical, and environmental behavior of uranium was published in Burns and Finch (1999). Topics covered in this compilation of papers include the reviews of the mineralogy and paragenesis of uranium minerals; the genesis of uranium ore deposits; the geochemical behavior of uranium in natural fluids; environmental aspects of uranium geochemistry, such as microbial effects, groundwater contamination, and nuclear waste disposal; and analytical techniques for characterization of uranium-bearing phases (Burns and Finch 1999). The geochemical processes affecting the mobility of uranium in the Hanford vadose zone are discussed in detail in Cantrell et al. (2007b). An in-depth review of uranium geochemistry at Hanford has been published recently by Zachara et al. (2007b).

\subsubsection{Oxidation States}

Uranium can exist in the $+3,+4,+5$, and +6 oxidation states in aqueous environments. Uranium(IV) and U(VI) are the most common oxidation states of uranium in natural environments. Uranium(IV) is stable under reducing conditions and is considered relatively immobile because U(IV) forms sparingly soluble minerals, such as uraninite $\left(\mathrm{UO}_{2}\right)$. Dissolved U(III) easily oxidizes to U(IV) under most reducing conditions found in nature. The $\mathrm{U}(\mathrm{V})$ aqueous species $\left(\mathrm{UO}_{2}{ }^{+}\right)$readily disproportionates to $\mathrm{U}(\mathrm{IV})$ and $\mathrm{U}(\mathrm{VI})$. Uranium exists in the +6 oxidation state under oxidizing to mildly reducing environments. The reduction of $\mathrm{U}(\mathrm{VI})$ to $\mathrm{U}(\mathrm{IV})$ has received considerable attention because the oxidation state of uranium has a significant effect on its mobility in waste streams and the natural environment. These reaction processes are the basis for certain remediation technologies, such as permeable barriers composed of zero-valent iron particles (i.e., as metallic iron) or sodium-dithionite-reduced sediments.

\subsubsection{Aqueous Speciation}

The Eh-pH diagram in Figure 3.1 shows the dominant aqueous species for dissolved uranium calculated at $25^{\circ} \mathrm{C}$ using a total activity of $2.12 \times 10^{-3} \mathrm{M}$ dissolved uranium and no dissolved phosphate. The activities for uranium and the other cations and complexing ligands used to calculate Figures 3.1 and 3.2 are from Table 3.1 and are discussed in Section 3.3. Plotting of Eh-pH regions where COI solids 


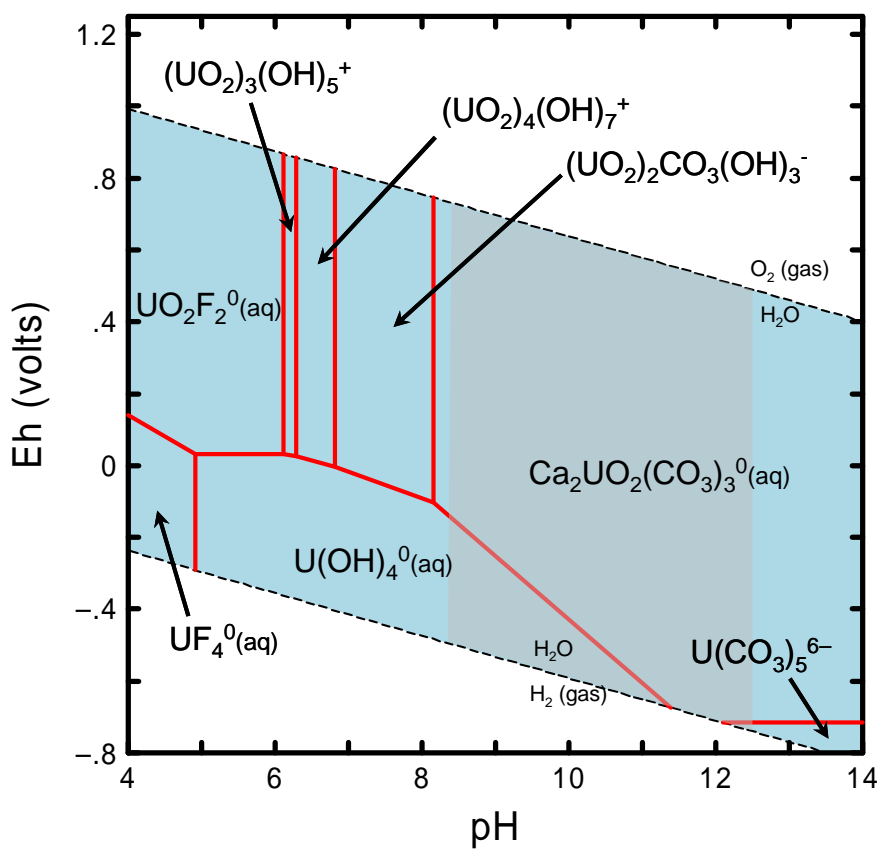

Figure 3.1. Dominant Aqueous Species of Uranium in the Absence of Dissolved Phosphate. Diagram was calculated at $25^{\circ} \mathrm{C}$ at a total activity of $2.12 \times 10^{-3} \mathrm{M}$ dissolved uranium and activities (effective concentrations) for other constituents (excluding phosphate) as given in Table 3.1. Eh-pH regions where precipitation of solids may occur have been suppressed in the calculations used to plot this figure but are shown in later figures related to this contaminant.

calculate to be oversaturated for the specified fluid composition was omitted in Figure 3.1 and all subsequent Eh-pH diagrams in order to show the dominant aqueous species. Eh-pH diagrams showing stability fields for potential solubility-limiting COI phases are provided as separate diagrams in each summary section. The light-gray-shaded area in Figure 3.1 and all subsequent Eh-pH diagrams shows the range of $\mathrm{pH}$ values thought to be important to COIs present in leachates from SST residual waste.

In Figure 3.1, the aqueous speciation of $\mathrm{U}(\mathrm{VI})$ at $\mathrm{pH}$ values greater than $\sim 8$ is dominated by the aqueous species $\mathrm{Ca}_{2} \mathrm{UO}_{2}\left(\mathrm{CO}_{3}\right)_{3}{ }^{0}(\mathrm{aq})$ from oxidizing to very reducing conditions. At $\mathrm{pH}$ values from $\sim 6$ to $\sim 8$, a series of $\mathrm{U}(\mathrm{VI})$ hydroxide complexes $\left(\mathrm{UO}_{2}\right)_{3}(\mathrm{OH})_{5}{ }^{+},\left(\mathrm{UO}_{2}\right)_{4}(\mathrm{OH})_{7}{ }^{+}$, and $\left(\mathrm{UO}_{2}\right)_{2} \mathrm{CO}_{3}(\mathrm{OH})_{3}{ }^{-}$is dominant at these solution compositions. At the activity of dissolved fluoride (Table 3.1) used for these calculations, speciation of dissolved U(VI) is dominated by a fluoride complex for $\mathrm{pH}$ values less than $\sim 6$. Under very reducing conditions, the $\mathrm{U}(\mathrm{IV})$ species $\mathrm{UF}_{4}{ }^{0}(\mathrm{aq}), \mathrm{U}(\mathrm{OH})_{4}{ }^{0}(\mathrm{aq})$, and $\mathrm{U}\left(\mathrm{CO}_{3}\right)_{5}{ }^{6-}$ are predicted to be dominant for $\mathrm{pH}$ values less than $\sim 5$, from $\sim 5$ to $\sim 11.4$, and above $\mathrm{pH} 12$, respectively.

Figure 3.1 shows the dominant aqueous species for dissolved uranium calculated at $25^{\circ} \mathrm{C}$ using total activities from Table 3.1, including $2.12 \times 10^{-3} \mathrm{M}$ dissolved uranium and $3.52 \times 10^{-3} \mathrm{M}$ dissolved phosphate. At this concentration of dissolved phosphate, the speciation of uranium is dominated by the $\mathrm{U}(\mathrm{VI})$ phosphate complexes $\mathrm{UO}_{2}\left(\mathrm{H}_{2} \mathrm{PO}_{4}\right)_{2}{ }^{0}(\mathrm{aq})$ and $\mathrm{UO}_{2} \mathrm{PO}_{4}{ }^{-}$over almost the entire Eh range at $\mathrm{pH}$ values less than $\sim 7$, based on the available thermodynamic data. Although the stability field for the complex $\mathrm{Ca}_{2} \mathrm{UO}_{2}\left(\mathrm{CO}_{3}\right)_{3}{ }^{0}$ (aq) decreased by approximately one $\mathrm{pH}$ unit from $\mathrm{pH} \sim 8$ to $\sim 9$, it is still predicted to dominate the speciation of uranium at high $\mathrm{pH}$ values (Figure 3.2). 


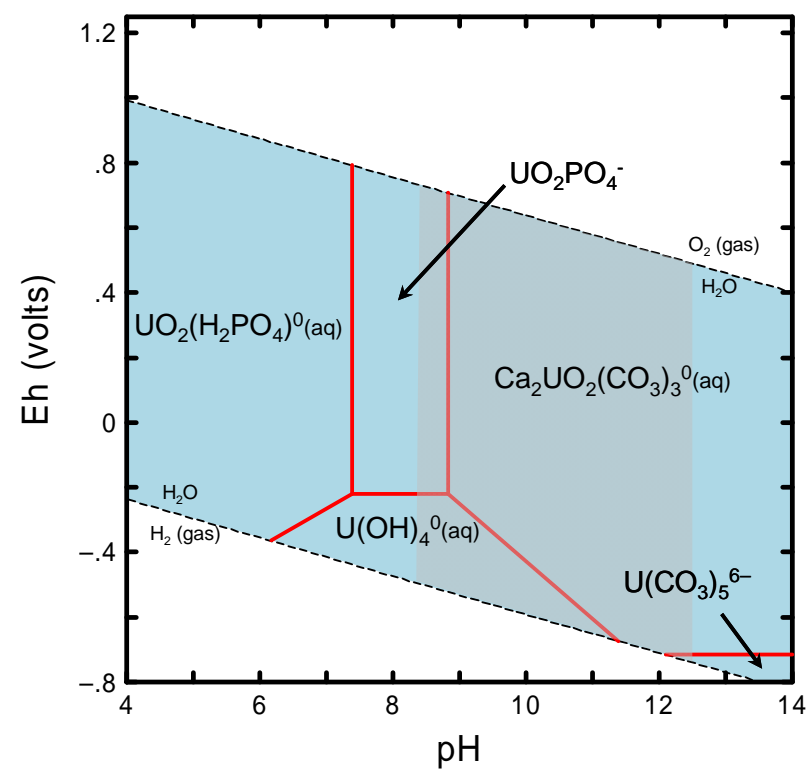

Figure 3.2. Dominant Aqueous Species of Uranium in the Presence of Dissolved Phosphate. Diagram was calculated at $25^{\circ} \mathrm{C}$ at a total activity of $2.12 \times 10^{-3} \mathrm{M}$ dissolved uranium and activities (effective concentrations) for other constituents as given in Table 3.1. Eh-pH regions where precipitation of solids may occur have been suppressed in the calculations used to plot this figure but are shown in later figures related to this contaminant.

Because Hanford Site uncontaminated groundwater is a calcium- and/or sodium-bicarbonatedominated groundwater (Horton 2007), dissolved U(VI) likely exists as carbonate-complexed aqueous species in the vadose zone $(\mathrm{pH} \sim 8)$ and upper unconfined aquifer environments at the Site. These $\mathrm{pH}$ and bicarbonate/carbonate conditions are within the range of conditions expected for leachates from tank residual waste, so dissolved $\mathrm{U}(\mathrm{VI})$ also is expected to be present predominantly as carbonate complexes in residual waste leachates. Direct verification of the uranyl carbonate dominance in contaminated vadose zone pore waters from borehole 299-E33-45 is presented in Knepp (2002, Appendix D). Recent studies (Bernhard et al. 1996, 2001; Kalmykov and Choppin 2000; Dong et al. 2005; Fox et al. 2006; Kelly et al. 2007) indicate that dissolved calcium uranyl carbonate complexes also have an important effect on the geochemical behavior of U(VI) in oxic, calcium-rich aqueous systems at near-neutral to basic $\mathrm{pH}$ conditions such as those at the Hanford Site. Bernhard et al. $(1996,2001)$ used spectroscopic techniques to investigate aqueous complexation in the system $\mathrm{Ca}^{2+}-\mathrm{U}(\mathrm{VI})-\mathrm{CO}_{3}{ }^{2-}-\mathrm{H}_{2} \mathrm{O}$. The results of their series of studies provide evidence for the formation of a strong, uncharged aqueous complex, $\mathrm{Ca}_{2} \mathrm{UO}_{2}\left(\mathrm{CO}_{3}\right)_{3}{ }^{0}(\mathrm{aq})$. Aqueous speciation calculations based on stability constants published by Kalmykov and Choppin (2000) and Bernhard et al. (2001) for the formation of $\mathrm{Ca}_{2} \mathrm{UO}_{2}\left(\mathrm{CO}_{3}\right)_{3}{ }^{0}(\mathrm{aq})$ indicate that this species would be a predominant species under oxidizing conditions from $\mathrm{pH} 6$ to 10 in calcium-rich waters containing dissolved U(VI). Studies by Dong et al. (2005) and Fox et al. (2006) also show that the formation of $\mathrm{Ca}_{2} \mathrm{UO}_{2}\left(\mathrm{CO}_{3}\right)_{3}{ }^{0}$ (aq) decreases the adsorption of $\mathrm{U}(\mathrm{VI})$ at $\mathrm{pH}$ values greater than 7 . In their detailed critical review of thermodynamic constants for key radionuclides, Guillaumont et al. (2003) did not accept the formation constants published for the aqueous complex $\mathrm{Ca}_{2} \mathrm{UO}_{2}\left(\mathrm{CO}_{3}\right)_{3}{ }^{0}$ (aq). Guillaumont et al. (2003) believed that the published studies provided excellent evidence for complex formation between cations ( such as $\mathrm{Ca}^{2+}$ ) and $\mathrm{UO}_{2}\left(\mathrm{CO}_{3}\right)_{3}{ }^{4-}$ but indicated that the constants listed in the literature had a large uncertainty and likely overpredicted the strength and stability of $\mathrm{Ca}_{2} \mathrm{UO}_{2}\left(\mathrm{CO}_{3}\right)_{3}{ }^{0}$ (aq). A detailed discussion of the reasons for their decision is given in Guillaumont et al. (2003). 
To test the sensitivity of the calculated Eh-pH diagrams to the available thermodynamic data for this complex, Eh-pH diagrams were calculated using the same solution composition but different $\log \mathrm{K}_{\mathrm{r}, 298^{\circ}}$ values for the formation reaction for $\mathrm{Ca}_{2} \mathrm{UO}_{2}\left(\mathrm{CO}_{3}\right)_{3}{ }^{0}(\mathrm{aq})$. If the $\log \mathrm{K}_{\mathrm{r}, 298}{ }^{\circ}$ value for $\mathrm{Ca}_{2} \mathrm{UO}_{2}\left(\mathrm{CO}_{3}\right)_{3}{ }^{0}$ (aq) is decreased by $2 \log$ units, the stability boundary between $\left(\mathrm{UO}_{2}\right)_{2} \mathrm{CO}_{3}(\mathrm{OH})_{3}{ }^{-}$and $\mathrm{Ca}_{2} \mathrm{UO}_{2}\left(\mathrm{CO}_{3}\right)_{3}{ }^{0}$ (aq) shifts from $\mathrm{pH} \sim 8.1$, as shown in Figure 3.1, to $\sim 8.7$. If the $\log \mathrm{K}_{\mathrm{r}, 298}{ }^{\circ}$ value is changed by $3 \log$ units, the dominant $\mathrm{U}(\mathrm{VI})$ species at $\mathrm{pH}$ values greater than $\sim 8.7$ calculates to be $\mathrm{UO}_{2}\left(\mathrm{CO}_{3}\right)_{3}{ }^{4-}$ instead of $\mathrm{Ca}_{2} \mathrm{UO}_{2}\left(\mathrm{CO}_{3}\right)_{3}{ }^{0}(\mathrm{aq})$.

\subsubsection{Solubility}

Uranium mineral solubility processes may be important also for some environmental conditions, and several uranium precipitates or coprecipitates may form, depending on the geochemical conditions (Frondel 1958; Falck 1991; Finch and Murakami 1999). Potentially important mineral solubility controls for dissolved $\mathrm{U}(\mathrm{VI})$ include minerals, such as autunite $\left[\mathrm{Ca}\left(\mathrm{UO}_{2}\right)_{2}\left(\mathrm{PO}_{4}\right)_{2} \cdot 10-12 \mathrm{H}_{2} \mathrm{O}\right]$, becquerelite $\left(\mathrm{CaU}_{6} \mathrm{O}_{19} \cdot 10 \mathrm{H}_{2} \mathrm{O}\right)$, boltwoodite $\left[(\mathrm{K}, \mathrm{Na})\left(\mathrm{UO}_{2}\right) \mathrm{SiO}_{3} \mathrm{OH} \cdot 1.5 \mathrm{H}_{2} \mathrm{O}\right]$, carnotite $\left[\left(\mathrm{K}_{2}\left(\mathrm{UO}_{2}\right)_{2}\left(\mathrm{VO}_{4}\right)_{2} \cdot 3 \mathrm{H}_{2} \mathrm{O}\right]\right.$, compreignacite $\left(\mathrm{K}_{2} \mathrm{U}_{6} \mathrm{O}_{19} \cdot 11 \mathrm{H}_{2} \mathrm{O}\right)$, potassium autunite $\left[\mathrm{K}_{2}\left(\mathrm{UO}_{2}\right)_{2}\left(\mathrm{PO}_{4}\right)_{2} \cdot 10-12 \mathrm{H}_{2} \mathrm{O}\right]$, rutherfordine $\left(\mathrm{UO}_{2} \mathrm{CO}_{3}\right)$, schoepite $\left(\mathrm{UO}_{3} \cdot 2 \mathrm{H}_{2} \mathrm{O}\right)$, sklodowskite $\left[\mathrm{Mg}\left(\mathrm{UO}_{2}\right)_{2}\left(\mathrm{SiO}_{3}\right)_{2}(\mathrm{OH})_{2} \cdot 5 \mathrm{H}_{2} \mathrm{O}\right]$, tyuyamunite $\left[\mathrm{Ca}\left(\mathrm{UO}_{2}\right)_{2}\left(\mathrm{VO}_{4}\right)_{2} \cdot 5-8 \mathrm{H}_{2} \mathrm{O}\right]$, and uranophane $\left[\mathrm{Ca}\left(\mathrm{UO}_{2}\right)_{2}\left(\mathrm{SiO}_{3}\right)_{2}(\mathrm{OH})_{2} \cdot 5 \mathrm{H}_{2} \mathrm{O}\right]($ Langmuir 1997).

For a total activity of $2.12 \times 10^{-3} \mathrm{M}$ dissolved uranium in the absence of dissolved phosphate and silica, the uranium phases schoepite and becquerelite calculate to be oversaturated from $\mathrm{pH}$ values of $\sim 5.5$ to $\sim 8.4$ under oxidizing conditions (see tan-colored areas in Figure 3.3). The activities of the cations and complexing ligands used to calculate Figures 3.3 and 3.4 are from Table 3.1 and are discussed in Section 3.3. Under reducing conditions, Figure 3.3 shows a large stability field for uraninite $\left(\mathrm{UO}_{2}\right)$ from $\mathrm{pH} \sim 4.6$ to greater than 12 for this solution composition.

For total activities of $2.12 \times 10^{-3} \mathrm{M}$ dissolved uranium and $3.52 \times 10^{-3} \mathrm{M}$ dissolved phosphate, the minerals saleeite $\left[\mathrm{Mg}\left(\mathrm{UO}_{2}\right)_{2}\left(\mathrm{PO}_{4}\right)_{2}\right]$ and ningyoite $\left[\mathrm{CaU}\left(\mathrm{PO}_{4}\right)_{2} \cdot 2 \mathrm{H}_{2} \mathrm{O}\right]$ calculate to be oversaturated at near-neutral $\mathrm{pH}$ oxidizing conditions and at $\mathrm{pH}$ values less than 8 under reducing conditions, respectively (see tan-colored areas in Figure 3.4). Under very reducing conditions, uraninite calculates to be oversaturated at $\mathrm{pH}$ values between $\sim 10.5$ and 13 (Figure 3.4).

Figure 3.5 shows the effect of the concentrations of dissolved carbonate and calcium on the predicted solubility controls for U(VI) (i.e., oxic conditions) at fixed $\mathrm{pH}$ values and concentrations of dissolved sodium expected for leachates from tank residual waste. The rows showing the concentration plots A and $\mathrm{B}, \mathrm{C}$ and $\mathrm{D}$, and $\mathrm{E}$ and $\mathrm{F}$ in Figure 3.5 were calculated assuming no dissolved sodium, a total dissolved sodium activity of $2.05 \times 10^{-2} \mathrm{M}$ (as listed in Table 3.1 ), and a sodium activity of $2.05 \times 10^{-1} \mathrm{M}$ (an order of magnitude greater sodium), respectively. Plots A, C, and E (left column) in Figure 3.5 were calculated at $\mathrm{pH} 8$, and plots $\mathrm{B}, \mathrm{D}$, and $\mathrm{F}$ (right column) at $\mathrm{pH} 10$. The areas colored blue and tan show stability fields for the indicated aqueous species and solids, respectively. The area in each concentration plot shaded in light gray shows the region where calcite $\left(\mathrm{CaCO}_{3}\right)$ is calculated to be oversaturated. At low concentrations of dissolved carbonate and no dissolved sodium or an activity of $2.05 \times 10^{-2} \mathrm{M}$ dissolved sodium (plots $\mathrm{A}$ and $\mathrm{C}$ in Figure 3.5), schoepite $\left(\mathrm{UO}_{3} \cdot 2 \mathrm{H}_{2} \mathrm{O}\right)$ and becquerelite $\left[\mathrm{Ca}\left(\mathrm{UO}_{2}\right)_{6} \mathrm{O}_{4}(\mathrm{OH})_{6} \cdot 8 \mathrm{H}_{2} \mathrm{O}\right]$ are stable at $\mathrm{pH} 8$ at low and high concentrations of dissolved calcium, respectively. At $\mathrm{pH} 10$ with no dissolved sodium, the stability field for becquerelite oversaturation 


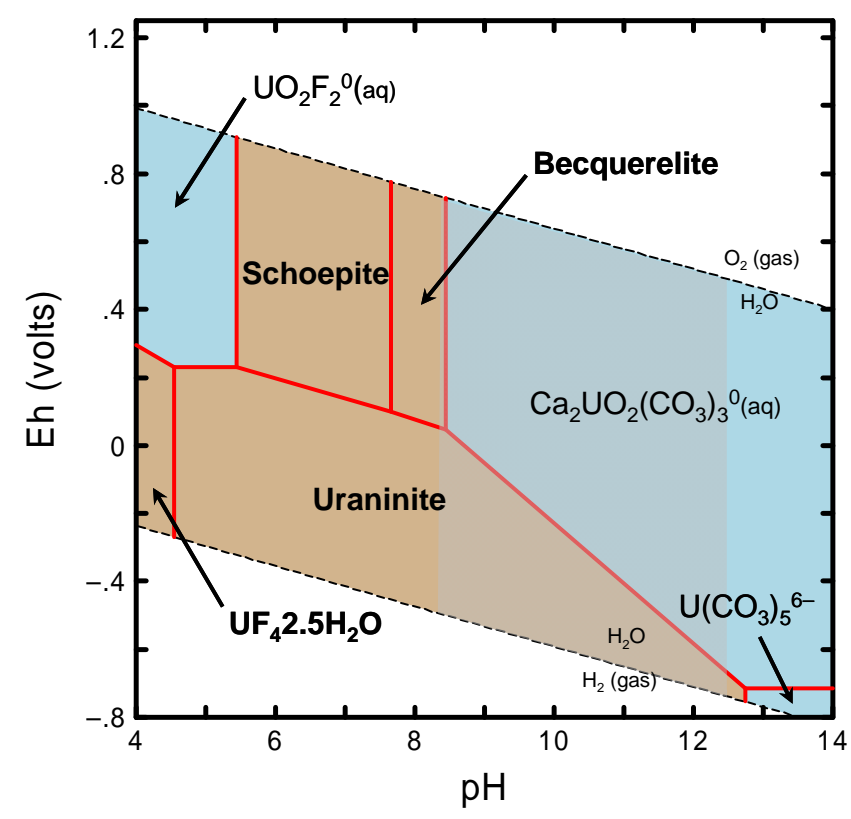

Figure 3.3. Stability Fields of Uranium Minerals in the Absence of Phosphate and Silica. Diagram was calculated at $25^{\circ} \mathrm{C}$ at a total activity of $2.12 \times 10^{-3} \mathrm{M}$ dissolved uranium and activities (effective concentrations) for other constituents (excluding phosphate) as given in Table 3.1.

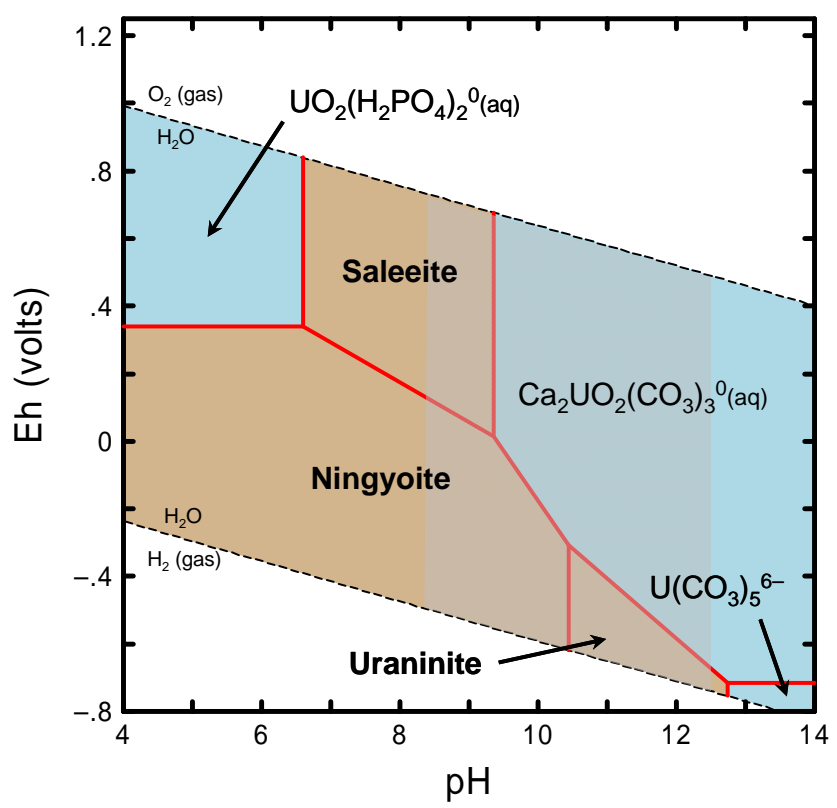

Figure 3.4. Stability Fields of Uranium Minerals in the Presence of Phosphate. Diagram was calculated at $25^{\circ} \mathrm{C}$ at a total activity of $2.12 \times 10^{-3} \mathrm{M}$ dissolved uranium and activities (effective concentrations) for other constituents as given in Table 3.1. 

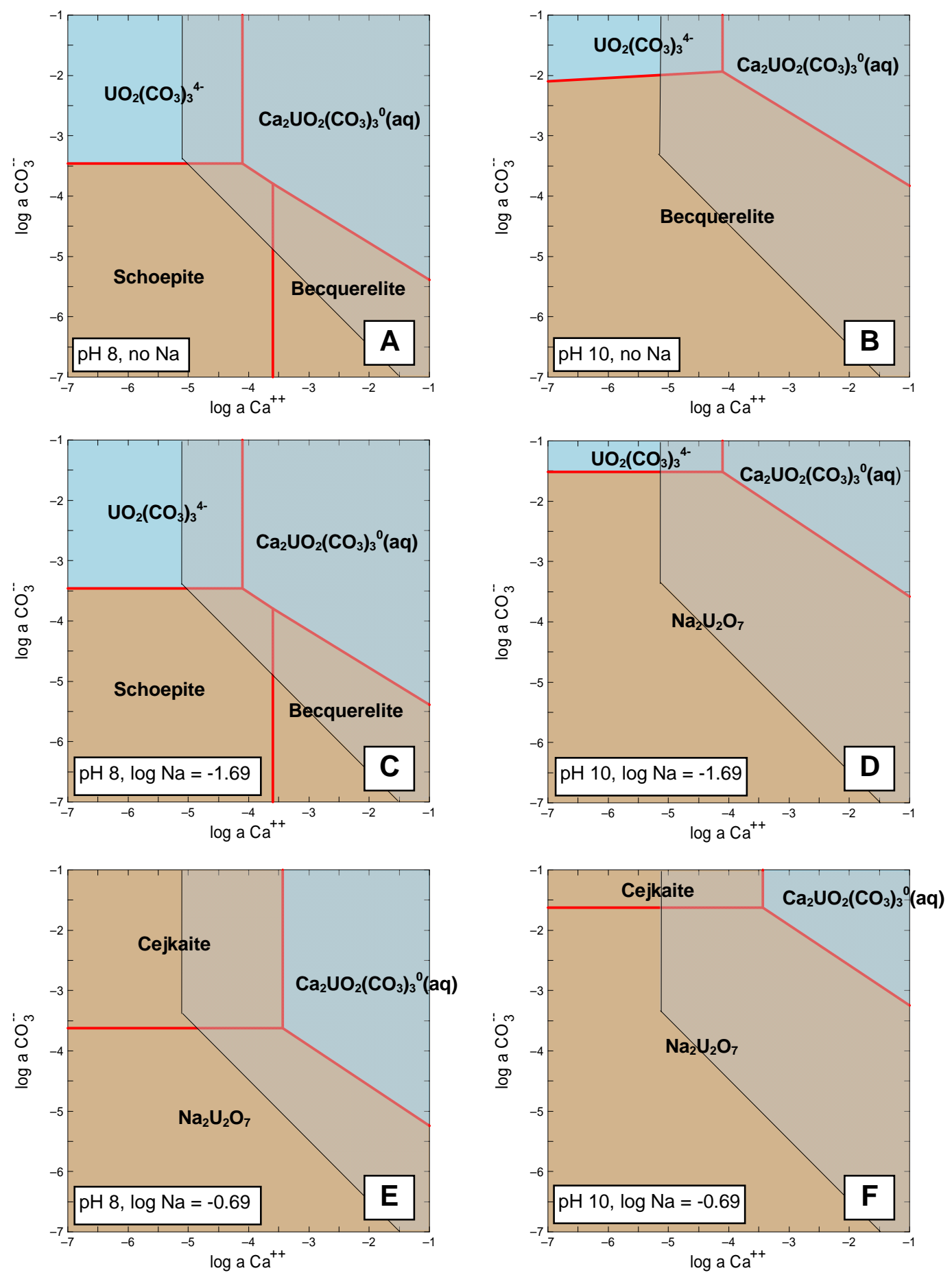

Figure 3.5. Concentration Plots Showing the Effect of Dissolved Carbonate and Calcium Concentrations of Solubility Controls for U(VI) at Selected Values of $\mathrm{pH}$ and Dissolved Sodium. Plots were calculated at $25^{\circ} \mathrm{C}$ at a total activity of $2.12 \times 10^{-3} \mathrm{M}$ dissolved uranium. 
extends over the complete range of calcium concentrations given in plot B in Figure 3.5. At $2.05 \times 10^{-2} \mathrm{M}$ dissolved sodium, the stability fields for schoepite and becquerelite are replaced at $\mathrm{pH} 10$ by oversaturation with respect to $\mathrm{Na}_{2} \mathrm{U}_{2} \mathrm{O}_{7}$ (plot $\mathrm{D}$ in Figure 3.5) and then with increasing sodium concentrations $\left(2.05 \times 10^{-1} \mathrm{M}\right)$, by $\mathrm{Na}_{2} \mathrm{U}_{2} \mathrm{O}_{7}$ and čejkaite $\left[\mathrm{Na}_{4}\left(\mathrm{UO}_{2}\right)\left(\mathrm{CO}_{3}\right)_{3}\right]$ at low and high carbonate concentrations, respectively (plots $\mathrm{E}$ and $\mathrm{F}$ in Figure 3.5).

The role of schoepite, becquerelite, $\mathrm{Na}_{2} \mathrm{U}_{2} \mathrm{O}_{7}$, and čejkaite as potential solubility limits for U(VI) in release models for residual waste from the SSTs is discussed in Sections 4.4.1 and 4.5.1. Čejkaite and $\mathrm{Na}_{2} \mathrm{U}_{2} \mathrm{O}_{7}$ [similar to clarkeite, $\left.\mathrm{Na}\left[\left(\mathrm{UO}_{2}\right) \mathrm{O}(\mathrm{OH})\right]\left(\mathrm{H}_{2} \mathrm{O}\right)_{0-1}\right]$ have also been identified in tank waste in SSTs C-203 and C-204 and have been included in the release model for uranium from waste in those SSTs (Deutsch et al. 2007b; Cantrell et al. 2006; Krupka et al. 2006a). If the sediment pore waters that seep into a closed SST and react with the residual waste contain sufficient concentrations of dissolved silica, then minerals such as soddyite $\left[\left(\mathrm{UO}_{2}\right)_{2} \mathrm{SiO}_{4} \cdot 2 \mathrm{H}_{2} \mathrm{O}\right]$ and uranophane $\left[\mathrm{Ca}\left(\mathrm{UO}_{2}\right)_{2}\left(\mathrm{SiO}_{3} \mathrm{OH}\right)_{2} \cdot 5\left(\mathrm{H}_{2} \mathrm{O}\right)\right]$ may control the solubility of dissolved U(VI) at high silica concentrations rather than schoepite and becquerelite, respectively. See Ritherdon et al. (2003) for a discussion of the solubility of U(VI) minerals in the $\mathrm{U}(\mathrm{VI})-\mathrm{Ca}-\mathrm{SiO}_{2}-\mathrm{H}_{2} \mathrm{O}$ system.

\subsubsection{Adsorption}

An extensive summary of published studies on uranium adsorption onto sediments, soils, crushed rock, and single minerals is given in EPA (1999b). The compilation by Cantrell et al. (2003) of adsorption data for U(VI) on Hanford sediment under natural Hanford groundwater conditions indicates that $\mathrm{U}(\mathrm{VI})$ adsorption is moderate with distribution coefficient $\left(\mathrm{K}_{\mathrm{d}}\right)$ values ranging from approximately 0.2 to $4 \mathrm{~mL} / \mathrm{g}$.

Uranium(VI) adsorbs onto a variety of minerals and related phases, including clays (e.g., Ames et al. 1982; Chisholm-Brause et al. 1994), oxides and silicates (e.g., Hsi and Langmuir 1985; Waite et al.

1994), and natural organic material (e.g., Borovec et al. 1979; Shanbhag and Choppin 1981; Read et al. 1993). Important environmental parameters affecting uranium adsorption include $\mathrm{pH}$, concentrations of complexing ligands (e.g., dissolved carbonate), redox conditions, ionic strength, and mineralogy. As with the adsorption of most dissolved metals, aqueous $\mathrm{pH}$ has a significant effect on $\mathrm{U}(\mathrm{VI})$ adsorption due to the consequence of $\mathrm{pH}$ on $\mathrm{U}(\mathrm{VI})$ aqueous speciation and the number of exchange sites on variably charged surfaces of solids such as iron oxides, aluminum oxides, and natural organic matter. For natural sediments, the maximum U(VI) adsorption occurs in the $\mathrm{pH}$ range of approximately 6 to 8 (EPA 1999b), with lower adsorption occurring at lower $\mathrm{pH}$ due to protonation of the adsorption sites and a shift to more positively charged uranyl species in solution (e.g., see Payne and Waite 1991). Lower adsorption also occurs at higher $\mathrm{pH}$ values due to the deprotonation of surface sites and the formation of higher charged anionic aqueous species $\left[\mathrm{UO}_{2}\left(\mathrm{CO}_{3}\right)_{3}{ }^{4-}\right]$ and poorly sorbing neutral ones $\left[\mathrm{Ca}_{2} \mathrm{UO}_{2}\left(\mathrm{CO}_{3}\right)_{3}{ }^{0}(\mathrm{aq})\right.$; (Dong et al. 2005; Fox et al. 2006)]. This trend is similar to the adsorption behavior measured for uranium onto single mineral phases such as those reported for iron oxides (Hsi and Langmuir 1985; Waite et al. 1992, 1994; Duff and Amrheim 1996), clays (Waite et al. 1992; McKinley et al. 1995; Turner et al. 1996), and quartz (Waite et al. 1992). 
Results of uranium sorption studies with cementitious materials indicate that compared to sediments at high basic $\mathrm{pH}$ values, uranium should readily sorb to cement and concrete. ${ }^{\text {(a) }}$ For example, Allard et al. (1984) and Hoglund et al. (1985) present data for the adsorption of uranium onto cements or concretes. Uranium was added as the oxidized form U(VI) to the simulated cement pore waters. For the seven types of concretes and the weathered concretes, the $\mathrm{K}_{\mathrm{d}}$ values for uranium ranged from 350 to $13,000 \mathrm{~mL} / \mathrm{g}$. The average $\mathrm{K}_{\mathrm{d}}$ value was $\sim 1,000$, and the median value was $1,400 \mathrm{~mL} / \mathrm{g}$. Allard et al. (1984) suggested that the increased uranium adsorption onto these concrete solids could be due to the formation of cationic polynuclear uranium species, such as $\left(\mathrm{UO}_{2}\right)_{3}(\mathrm{OH})_{5}{ }^{+}$, at the higher uranium concentrations and/or the precipitation of sparingly soluble alkali or alkaline earth metal uranates in the high $\mathrm{pH}$ pore water. Although the behavior of uranium in aqueous systems is known to be sensitive to redox conditions, there was no significant increase in the uranium $\mathrm{K}_{d}$ value measured in the experiments that used concrete containing blast furnace slag (BFS), an expected reductant. Table 3.2 lists the bounding minimum $\mathrm{K}_{\mathrm{d}}$ values selected by Krupka and Serne (1998) and Bradbury and Van Loon (1998) for uranium onto cement/concrete, based on the results of studies they cite. Krupka and Serne (1998) followed the convention of Bradbury and Sarott (1995) by assigning $K_{d}$ values for most of the COIs present in the latestage cementitious system (Environment III in Table 3.2) at one-tenth of those $\mathrm{K}_{\mathrm{d}}$ values selected for radionuclides associated with the earlier stage of the cementitious system (Environment II). The cement environments are summarized in Table 3.2.

Table 3.2. Bounding Minimum $\mathrm{K}_{\mathrm{d}}$ Values $(\mathrm{mL} / \mathrm{g}$ ) for Uranium (from Krupka and Serne 1998 and Bradbury and Van Loon 1998)

\begin{tabular}{|c|c|c|c|}
\hline \multirow{2}{*}{\multicolumn{2}{|c|}{ Cement Environment }} & \multicolumn{2}{|c|}{$\mathrm{K}_{\mathrm{d}}$ Values $(\mathrm{mL} / \mathrm{g})$} \\
\hline & & \multirow{2}{*}{$\begin{array}{c}\text { Krupka and } \\
\text { Serne (1998) } \\
1,000\end{array}$} & \multirow{2}{*}{ 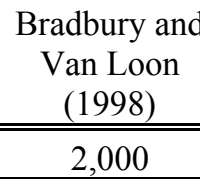 } \\
\hline \multirow{2}{*}{$\begin{array}{l}\text { I - Environment occurs immediately after cement hardens; } \\
\text { cement pore water has high pH ( }>12.5) \text {, high ionic strength, } \\
\text { and high } \mathrm{K} \text { and Na concentrations. }\end{array}$} & Oxidizing & & \\
\hline & Reducing & 2,000 & 5,000 \\
\hline \multirow{2}{*}{$\begin{array}{l}\text { II - Alkali metals are all dissolved, and cement pore water } \\
\mathrm{pH} \text { is controlled at } \sim 12.5 \text { by } \mathrm{Ca}(\mathrm{OH})_{2} \text { solubility. }\end{array}$} & Oxidizing & 1,000 & 2,000 \\
\hline & Reducing & 2,000 & 5,000 \\
\hline \multirow{2}{*}{$\begin{array}{l}\text { III - Concentration of } \mathrm{Ca}(\mathrm{OH})_{2} \text { has decreased and solubility } \\
\text { of } \mathrm{CSH} \text { (gel) controls cement pore water chemistry to a pH } \\
\text { of } \sim 10 \text { or less and low ionic strength. }\end{array}$} & Oxidizing & 100 & 100 \\
\hline & Reducing & 200 & 1,000 \\
\hline
\end{tabular}

\subsection{Technetium-99}

Technetium (Tc) (atomic number 43) is a member of Group VIIB in the periodic classification of the elements. Technetium-99 is generated as a fission product during the irradiation of uranium-containing nuclear fuels. Technetium-99 is an isotope of primary importance to waste disposal and remediation activities at the Hanford Site because of its long half-life and its high mobility as an oxyanion species in most geochemical systems. Technetium-99 has a $t_{1 / 2}$ of $2.11 \times 10^{5} \mathrm{yr}$ (Tuli 2004). The behavior of

(a) In these discussions and in Krupka and Serne (1998), $\mathrm{K}_{\mathrm{d}}$ values are reported as listed in original sources, and no attempt has been made to evaluate the original studies to determine if the reported $\mathrm{K}_{\mathrm{d}}$ values represent reversible sorption or precipitation as the sequestration process. Readers are cautioned, as noted in EPA (1999a), that high $\mathrm{K}_{\mathrm{d}}$ values, such as those greater than $1,000 \mathrm{~mL} / \mathrm{g}$, likely represent precipitation of the contaminant of interest and not reversible adsorption or ion exchange. Information regarding the proposed sequestration process is provided in our discussions if this is presented in the original source. 
technetium in environmental systems has been reviewed extensively by Ames and Rai (1978), Wildung et al. (1979), Onishi et al. (1981), Coughtrey et al. (1983), Beasley and Lorz (1984), Meyer et al. (1985), Sparks and Long (1987), Gu and Schulz (1991), Lieser (1993), and others. Hughes and Rossotti (1987) review in detail the solution chemistry of technetium. Rard et al. (1999) have published an extensive critical review of the thermodynamics of technetium. It is the most detailed review completed to date of the chemistry and available thermodynamic data for inorganic technetium compounds. The geochemical processes affecting the mobility of technetium-99 in the Hanford vadose zone are discussed in detail in Cantrell et al. (2007b).

\subsubsection{Oxidation States}

Technetium exists in oxidation states from +7 to -1 . In natural environments, the most stable oxidation states are +7 and +4 under oxidizing and reducing conditions, respectively. Other oxidation states are encountered chiefly in complex compounds (Mazzi 1989). The chemical behaviors of technetium in the +7 and +4 oxidation states differ drastically. In the +7 oxidation state, dissolved technetium exists as the pertechnetate anion, $\mathrm{TcO}_{4}{ }^{-}$, over the complete $\mathrm{pH}$ range of natural waters. Because the pertechnetate anion is highly soluble and is not strongly adsorbed at neutral and basic $\mathrm{pH}$ conditions, it is highly mobile in most oxidizing environmental systems. In the +4 valence state, technetium forms the sparingly soluble $\mathrm{TcO}_{2} \cdot \mathrm{nH}_{2} \mathrm{O}$ solid and is relatively immobile in the absence of strongly complexing ligands.

Because it has a significant effect on the mobility of technetium in waste streams, vadose zones, sediments, and groundwaters, the reduction of Tc(VII) to Tc(IV) by abiotic and biotic processes has recently been the subject of extensive studies. These reaction processes are the basis for certain remediation technologies, such as permeable barriers composed of zero-valent iron particles or sodiumdithionite reduced soils, which are currently being tested for immobilization of groundwater contaminants. Examples of studies of Tc(VII) reduction to Tc(IV) include those of biotic reduction by Lloyd and Macaskie (1996), Lloyd et al. (1997, 1998, 1999, 2000), Wildung et al. (2000), and Fredrickson et al. (2000); and abiotic reduction by Bondietti and Francis (1979), Haines et al. (1987), Eriksen and Cui (1991), Byegård et al. (1992), Wharton et al. (2000), and Zachara et al. (2007a).

\subsubsection{Aqueous Speciation}

Figure 3.6 is an Eh-pH diagram that shows the dominant aqueous hydrolytic species of technetium in the absence of dissolved ligands other than hydroxide. The diagram was calculated at $25^{\circ} \mathrm{C}$ using a total activity of $1.62 \times 10^{-9} \mathrm{M}$ dissolved technetium. The activities of technetium and the other cations and complexing ligands used to calculate Figure 3.6 are from Table 3.1 and are discussed in Section 3.3. Dissolved technetium is present under oxic conditions as the aqueous $\mathrm{Tc}(\mathrm{VII})$ oxyanion species $\mathrm{TcO}_{4}{ }^{-}$ over the complete $\mathrm{pH}$ range of natural waters and has little propensity to form aqueous complexes with dissolved cations (Rard et al. 1999). Under reducing conditions, technetium aqueous speciation is dominated at $\mathrm{pH}$ values greater than 2 by the neutral $\mathrm{Tc}(\mathrm{IV})$ species $\mathrm{TcO}(\mathrm{OH})_{2}{ }^{0}$ (aq) (Figure 3.6). The database used for these Eh-pH calculations does not include thermodynamic values for any aqueous Tc(IV) carbonate complexes. As discussed below, Tc(IV) carbonate complexes likely occur and would affect the distribution of Tc(IV) species shown in Figure 3.6 at alkaline $\mathrm{pH}$ values. The results of the calculated Eh-pH diagram (Figure 3.6) also indicate the possible formation of $\mathrm{Tc}^{3+}$ at $\mathrm{pH}$ values less than 2 under extremely reducing conditions. 


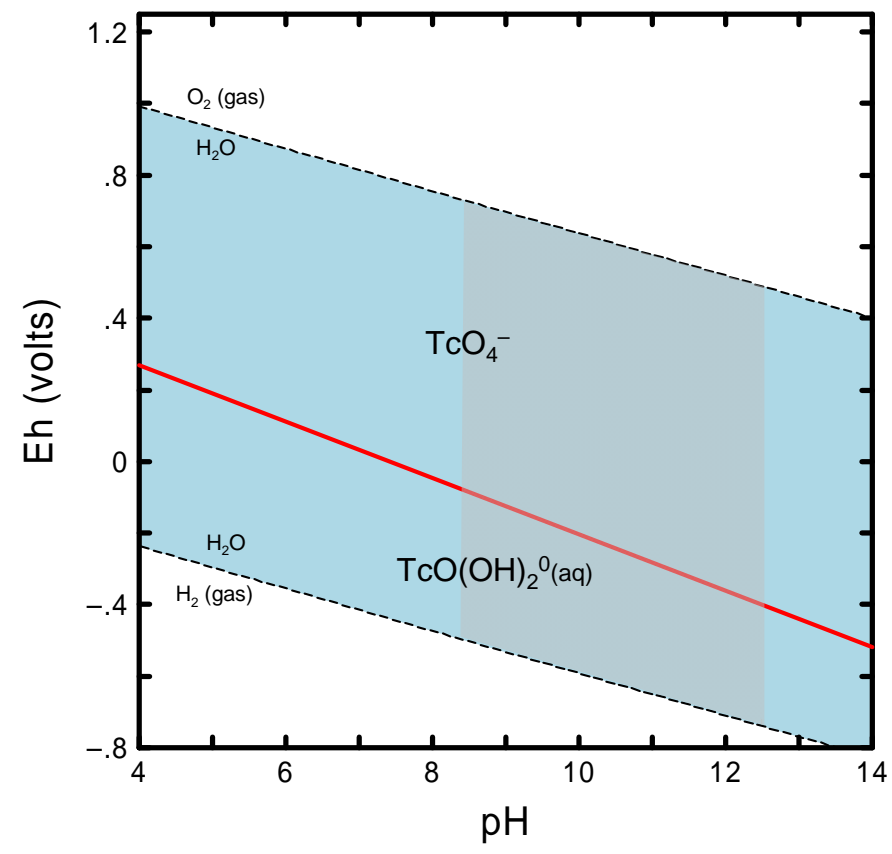

Figure 3.6. Dominant Aqueous Species of Technetium. Diagram was calculated at $25^{\circ} \mathrm{C}$ at a total activity of $1.62 \times 10^{-9} \mathrm{M}$ dissolved technetium and activities (effective concentrations) for other constituents as given in Table 3.1. Eh-pH regions where precipitation of solids may occur have been suppressed in the calculations used to plot this figure but are shown in the next figure related to this contaminant.

Many species distribution calculations and Eh-pH diagrams presented in the literature published before the critical review by Rard et al. (1999) included the aqueous neutral dimer species $\left[\mathrm{TcO}(\mathrm{OH})_{2}\right]_{2}{ }^{0}(\mathrm{aq})$. In many calculations, $\left[\mathrm{TcO}(\mathrm{OH})_{2}\right]_{2}{ }^{0}(\mathrm{aq})$ was predicted to be the dominant $\mathrm{Tc}(\mathrm{IV})$ species at neutral and basic $\mathrm{pH}$ values instead of the monomer $\mathrm{TcO}(\mathrm{OH})_{2}{ }^{0}(\mathrm{aq})$. Rard et al. (1999) found it difficult to evaluate the results of the study on which the dimer species and associated thermodynamic constant were based; therefore, their review team did not accept the dimer results and did not include the species $\left[\mathrm{TcO}(\mathrm{OH})_{2}\right]_{2}{ }^{0}(\mathrm{aq})$ in their thermodynamic database of technetium compounds.

Although the thermodynamic stability of $\mathrm{TcO}_{4}{ }^{-}$is well established, thermodynamic data for other aqueous complexes and solids containing technetium in its various valence states are extremely limited (see Rard et al. 1999). The absence of such data precludes the use of thermodynamic calculations to evaluate the environmental behavior of reduced species of dissolved technetium with respect to $\mathrm{pH}$, Eh, and the presence of potentially important dissolved complexing ligands such as dissolved carbonate, nitrate, phosphate, sulfate, chloride, and others. Studies of technetium under reducing conditions are limited compared to the number of technetium studies conducted under oxic conditions.

Technetium(IV) carbonate complexes likely affect the aqueous speciation and solubility of Tc(IV) at near-neutral and/or basic $\mathrm{pH}$ conditions. The Tc(IV) carbonate complexes $\mathrm{TcCO}_{3}(\mathrm{OH})_{2}{ }^{0}(\mathrm{aq})$ and $\mathrm{TcCO}_{3}(\mathrm{OH})_{3}{ }^{-}$are the only non-hydrolytic aqueous complexes of Tc for which Rard et al. (1999) list thermodynamic values. The thermodynamic constants listed for $\mathrm{TcCO}_{3}(\mathrm{OH})_{2}{ }^{\circ}(\mathrm{aq})$ and $\mathrm{TcCO}_{3}(\mathrm{OH})_{3}{ }^{-}$are based on the solubility study of solid $\mathrm{TcO}_{2} \cdot \mathrm{xH}_{2} \mathrm{O}$ completed in the presence and absence of $\mathrm{CO}_{2}$ (gas) by Eriksen et al. (1992). However, no independent measurements exist to verify the composition and thermodynamic properties of the Tc(IV) aqueous carbonate complexes. 
The results of other studies suggest the formation of $\mathrm{Tc}(\mathrm{IV})$ aqueous carbonate complexes. For example, Paquette and Lawrence (1985) reported spectrographic evidence for the formation of aqueous carbonate complexes with both Tc(III) and Tc(IV). Wildung et al. (2000) studied the effects of the presence of electron donors and dissolved bicarbonate on enzymatic reduction of Tc(VII) by the metalreducing bacterium Shewanella putrefaciens CN32. Based on the results of their experiments completed in bicarbonate solutions, Wildung et al. (2000) proposed the formation of a soluble, negatively charged $\mathrm{Tc}(\mathrm{IV})$ carbonate complex that exceeds $\mathrm{Tc}(\mathrm{VII})$ in electrophoretic mobility and possibly dominates the speciation of dissolved Tc(IV) over neutral and basic $\mathrm{pH}$ values. Generally, it has been assumed that technetium mobility in reducing environments is limited by the low solubility of $\mathrm{Tc}(\mathrm{IV})$ hydrous oxide (Section 3.5.3) and adsorption of aqueous Tc(IV) hydrolytic complexes. Given that anionic aqueous complexes typically do not readily adsorb to sediments and similar geologic materials under near-neutral and basic $\mathrm{pH}$ conditions, Wildung et al. (2000) suggested that the formation of anionic Tc(IV) carbonate complex(es) may represent an important mechanism for technetium migration in reducing geochemical environments. Given that dissolved carbonate is ubiquitous in tank environments and in surface and subsurface geochemical environments, further research is needed to determine the composition and thermodynamic properties of Tc(IV) carbonate complexes if reducing conditions are thought to be present in any probable Hanford Site-specific environments of interest to tank closure.

The potential complexation of technetium by dissolved EDTA, HEDTA, NTA, citrate, hydroacetic acid (or glycolate), TBP, and cyanide is important with respect to the chemical state of technetium in the underground storage tanks at the Hanford Site and its release to the environment (Krupka and Serne 2002). Krupka and Serne (2002) searched the stability constant database of Smith et al. (1997) to determine if data existed to calculate the thermodynamic distribution of technetium aqueous species containing any of these complexing ligands. The database by Smith et al. (1997) contains the Tc(VII) and $\mathrm{Tc}(\mathrm{IV})$ oxidation states but does not list any stability constants for $\mathrm{Tc}(\mathrm{VII})$ and $\mathrm{Tc}(\mathrm{IV})$ aqueous complexes with EDTA, HEDTA, NTA, citrate, hydroacetic acid (or glycolate), TBP, or cyanide. It is important to keep in mind that the lack of thermodynamic data for such complexes in an extensive well-accepted database such as by Smith et al. (1997) ${ }^{(a)}$ does not mean that such complexes are not important. The lack of tabulated thermodynamic constants may simply indicate that the formation of such complexes has not been studied from the perspective of determining their thermodynamic constants and/or that data available for such complexes are suspect and require additional study and independent determination.

Rard et al. (1999) review the available published studies for the complexation of technetium with cyanides and oxycyanides. The formation of complexes such as $\mathrm{Tc}^{\mathrm{VII}} \mathrm{O}(\mathrm{OH})_{2}(\mathrm{CN})_{4}^{-}, \mathrm{Tc}^{\mathrm{V}} \mathrm{O}(\mathrm{CN})_{5}{ }^{2-}$, $\mathrm{Tc}^{\mathrm{V}} \mathrm{O}_{2}(\mathrm{CN})_{4}^{3-}$, and $\mathrm{Tc}^{\mathrm{VI}} \mathrm{NCl}_{3}(\mathrm{CN})^{-}$have been suggested by these studies, but thermodynamic data are not available for such compounds (Rard et al. 1999).

Hughes and Rossotti (1987) reviewed the literature pertaining to the solution chemistry of technetium as it relates to the reprocessing of nuclear fuels. The results of their review indicate that technetium forms stable complexes with aminopolycarboxylates, of which EDTA is the most common. Gorski and Koch

(a) The National Institute of Standards and Technology (NIST) distributes the computerized database of critically selected stability constants by Smith et al. (1997). The computerized database by Smith et al. (1997) supersedes the printed tabulations of stability constants published by these authors, such as Smith and Martell (1976), for stability constants for inorganic complexes. 
$(1970)^{(a)}$ used an ion exchange method to study the complexation of technetium with aminopolycarboxylates. They determined a stability constant $(\log \mathrm{K})$ of 19.1 for the formation of $\left[\mathrm{Tc}^{\mathrm{IV}} \mathrm{OOH}(\mathrm{EDTA})\right]^{3-}$. Later studies by Russell et al. (1980) indicated that the net charge for this EDTA complex was -2, and the complex might be $\left[\mathrm{Tc}^{\mathrm{III}} \mathrm{OH}(\mathrm{EDTA})\right]^{2-},\left[\mathrm{Tc}^{\mathrm{IV}} \mathrm{O}(\mathrm{EDTA})\right]^{2-}$, or $\left[\mathrm{Tc}^{\mathrm{V}} \mathrm{O}(\mathrm{OH})(\mathrm{EDTA})\right]^{2-}$. Based on the relative stabilities of the technetium oxidation states, Russell et al. (1980) proposed that the complex was most likely a Tc(III)-EDTA complex. Gorski and Koch (1970) also determined stability constants for the formation of Tc(IV)-NTA complexes. These constants included $\log \mathrm{K}_{1}$ of 13.8 for $\left[\mathrm{Tc}^{\mathrm{IV}} \mathrm{OOH}(\mathrm{NTA})\right]^{2-}$ and $\log \mathrm{K}_{1} \mathrm{~K}_{2}$ of 28.7 for $\left[\mathrm{Tc}^{\mathrm{IV}} \mathrm{OOH}(\mathrm{NTA})_{2}\right]^{5-}$, where $\mathrm{K}_{1}$ and $\mathrm{K}_{2}$ are the stepwise formation constants for the complexation of $\mathrm{TcOOH}^{+}$with $\mathrm{NTA}^{3-}$. Hughes and Rossotti (1987) noted that the validity of these constants has been doubted by Noll et al. (1980) based on the irreversibility of the systems.

\subsubsection{Solubility}

Solubility processes may control the concentration of dissolved technetium under reducing conditions. Technetium(VII), as $\mathrm{TcO}_{4}^{-}$, is highly soluble, and does not form solubility-controlling phases in geochemical systems. Figure 3.7 shows the Eh-pH conditions (tan area) under which an aqueous solution at $25^{\circ} \mathrm{C}$ containing a total activity of $2.8 \times 10^{-8} \mathrm{M}$ dissolved technetium calculates to be oversaturated with $\mathrm{TcO}_{2} \cdot 2 \mathrm{H}_{2} \mathrm{O}(\mathrm{am})$ in the absence of dissolved sulfur. The activities of the cations and complexing ligands used to calculate Figure 3.7 are from Table 3.1 and are discussed in Section 3.3. At concentrations of less than this for technetium and other species, the system is undersaturated over all Eh-pH conditions with respect to $\mathrm{TcO}_{2} \cdot 2 \mathrm{H}_{2} \mathrm{O}(\mathrm{am})$. Numerous investigations have been conducted on the properties and hydration number of solid $\mathrm{TcO}_{2} \cdot \mathrm{nH}_{2} \mathrm{O}$ (see review of studies in Rard et al. 1999). Characterization data for this solid are limited, and a range of compositions, such as $\mathrm{TcO}_{2}(\mathrm{cr}), \mathrm{TcO}_{2} \cdot \mathrm{nH}_{2} \mathrm{O}, \mathrm{TcO}(\mathrm{OH})_{2}$, and $\mathrm{Tc}(\mathrm{OH})_{4}$, have been proposed by various investigators. This solid is considered to be essentially amorphous (Rard et al. 1999). If a total activity of $5.03 \times 10^{-5}$ dissolved sulfate and reduction of dissolved sulfate to sulfide are included in the calculation of Figure 3.7, then most of the stability field for $\mathrm{TcO}_{2} \cdot 2 \mathrm{H}_{2} \mathrm{O}(\mathrm{am})$ under very reducing conditions is replaced by stability fields showing oversaturation with respect to the sulfides $\mathrm{Tc}_{2} \mathrm{~S}_{7}$ and $\mathrm{TcS}_{2}$.

In reduced iron-sulfide systems, Wharton et al. (2000) have shown that $\mathrm{Tc}(\mathrm{VII})$ can be reduced to $\mathrm{Tc}(\mathrm{IV})$ with coprecipitation with FeS solid (the mineral mackinawite). Due to the poorly ordered structures of the precipitates, Wharton et al. (2000) were not able to confirm if Tc(IV) was incorporated in the structure of the FeS solid or precipitated as a distinct technetium solid phase. Their XAS results suggest that the reduction of technetium at these conditions may have precipitated a $\mathrm{TcS}_{2}$-like phase (Wharton et al. 2000).

(a) Information cited from Gorski and Koch (1970), Noll et al. (1980), and Russell et al. (1980) taken as given from Hughes and Rossotti (1987). Copies of the original references were not available for this review. 


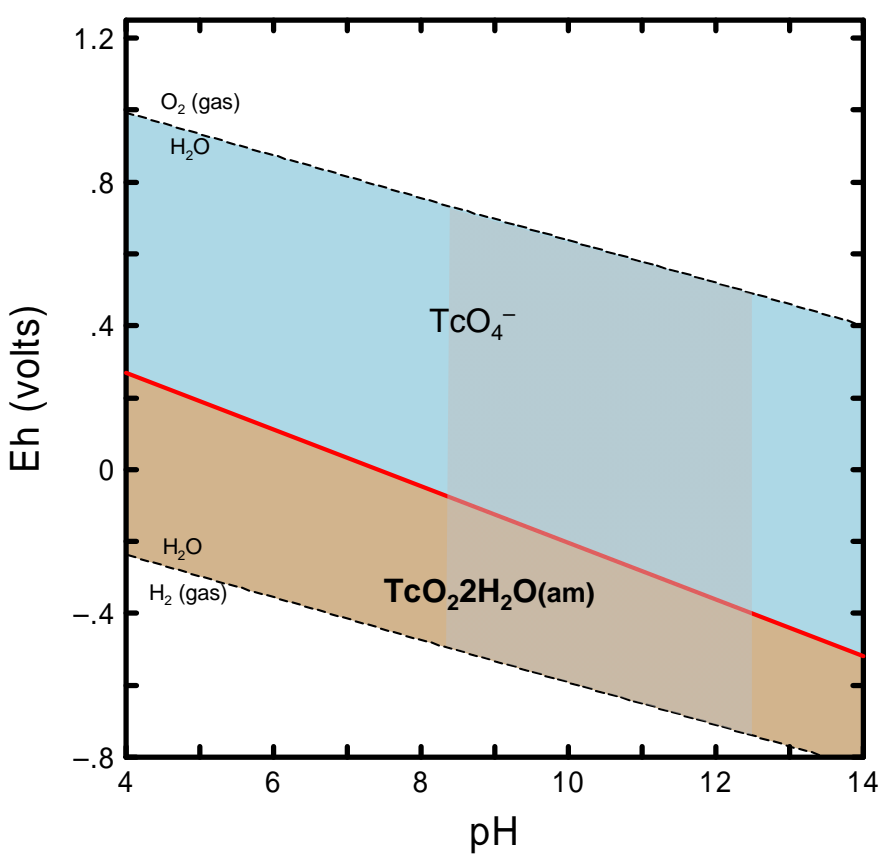

Figure 3.7. Dominant Aqueous Species of Technetium and Eh-pH Region (tan area) Where the Solubility of Solid Amorphous $\mathrm{TcO}_{2} \cdot 2 \mathrm{H}_{2} \mathrm{O}$ Has Been Exceeded. Diagram was calculated at $25^{\circ} \mathrm{C}$ in the absence of dissolved sulfate at a total activity of $\sim 2.8 \times 10^{-8} \mathrm{M}$ dissolved technetium and activities (effective concentrations) for other constituents as given in Table 3.1.

Large $\mathrm{K}_{\mathrm{d}}$ values have been measured for $\mathrm{Tc}(\mathrm{VII})$ in experiments conducted under oxic conditions with geologic materials containing reduced chemical components, such as Fe(II) and sulfide. These large $\mathrm{K}_{d}$ values likely result from the reduction of $\mathrm{Tc}(\mathrm{VII})$ to $\mathrm{Tc}(\mathrm{IV})$ and subsequent precipitation of $\mathrm{Tc}(\mathrm{IV})$ as discrete and/or coprecipitated solid phases. A recent study by Krupka et al. (2006b) showed that Re(VII), as a surrogate for $\mathrm{Tc}(\mathrm{VII})$, is sorbed onto iron oxides/hydroxides that precipitate during the corrosion of A-516 carbon steel coupons. The rhenium sorbed onto these corroded carbon steel coupons is in the +7 oxidation state. Krupka et al. (2006b) also reported preliminary results from Tc(VII)-99 spiked sorption experiments similar to those completed with rhenium. The results of their 30-day Tc(VII)-99 spiked experiments indicated that technetium, like rhenium, was sorbed onto the iron oxides/hydroxides that formed during corrosion of the carbon steel. However, in the Tc(VII)-99 spiked experiments, results of analyses by XANES and EXAFS indicated that approximately $80 \%$ to $100 \%$ of technetium- 99 sorbed to iron oxides/hydroxides was in the +4 oxidation state. Work continues on trying to identify the specific mechanism responsible for the sorption of technetium- 99 with the steel corrosion products, but these results suggest that the technetium-99 had precipitated during the corrosion of steel. Preliminary analyses indicate that the technetium-99 probably had coprecipitated with an iron oxide/hydroxide phase and not as a discrete technetium dioxide phase.

\subsubsection{Adsorption}

Numerous studies on the sorption of technetium on sediments, pure minerals, oxide phases, and crushed rock materials have been conducted. An extensive review of these studies is presented in EPA (2004). These studies consist primarily of measurements of $K_{d}$ values for Tc(VII). The adsorption of the 
$\mathrm{Tc}$ (VII) oxyanion $\mathrm{TcO}_{4}{ }^{-}$is expected to be very low to zero, i.e., $\mathrm{K}_{\mathrm{d}}$ values of $\approx 0 \mathrm{~mL} / \mathrm{g}$, at near-neutral and basic $\mathrm{pH}$ conditions in sediments low in organic matter and to increase when $\mathrm{pH}$ values decrease to less than 5. The $\mathrm{K}_{\mathrm{d}}$ values measured for $\mathrm{Tc}(\mathrm{VII})$ on Hanford sediment indicate that $\mathrm{Tc}(\mathrm{VII})$ adsorption is low under nearly all conditions relevant to the Hanford vadose zone and upper unconfined aquifer, with $\mathrm{K}_{\mathrm{d}}$ values ranging from zero to a high of approximately $1 \mathrm{~mL} / \mathrm{g}$ (Cantrell et al. 2003).

Krupka and Serne (1998) identified only one study of the adsorption of technetium (as technetium-95m) onto cement or concrete. Bayliss et al. (1992) completed adsorption experiments in anoxic gloveboxes using $0.05 \mathrm{M}$ of sodium dithionite solution to ensure highly reducing conditions for their experiments. They used OPC with limestone flour as an "aggregate." During the first 6 weeks of their experiments, Bayliss et al. (1992) observed a decrease in the concentration of dissolved technetium. Some loss of dissolved technetium was observed also in control experiments that did not contain any cement. Bayliss et al. (1992) suggested that the technetium loss in these control experiments was due to adsorption of technetium on the container walls and did not result from solubility-driven precipitation because the technetium solubility limit was much higher than the initial technetium concentrations used for their experiments. There was, however, no way to distinguish between these two processes. After 7 weeks, the measured $\mathrm{K}_{d}$ values were 5,000 $\pm 1,200 \mathrm{~mL} / \mathrm{g}$ for the cement-equilibrated water and 2,300 \pm $1,700 \mathrm{~mL} / \mathrm{g}$ for the saline-cement-equilibrated water. These results were obtained at measured Eh values of -228 (non-saline conditions) to -264 (saline conditions) at $\mathrm{pH}$ values of 13.1 and 12.6, respectively.

Bounding minimum $\mathrm{K}_{\mathrm{d}}$ values selected by Krupka and Serne (1998) and Bradbury and Van Loon (1998) for the adsorption of technetium onto cement/concrete are listed in Table 3.3. Given the lack of sorption data for technetium onto cementitious materials, Krupka and Serne (1998) defaulted to a $K_{d}$ value of 0 for technetium for all three cement environments under oxidizing conditions (Table 3.3). This assumed that $\mathrm{Tc}(\mathrm{VII})$ is present under oxidizing conditions. For a cementitious system that is expected to be reducing and where technetium is present as Tc(IV) or Tc(III), Krupka and Serne (1998) selected a $\mathrm{K}_{d}$ value of $1,000 \mathrm{~mL} / \mathrm{g}$ for Environments I and II as $1,000 \mathrm{~mL} / \mathrm{g}$ and a value of $100 \mathrm{~mL} / \mathrm{g}$ for Environment III. Krupka and Serne (1998) assumed that the $\mathrm{K}_{\mathrm{d}}$ values reported by Bayliss et al. (1992) were measured for reducing conditions and that the technetium was present as Tc(IV) in their experiments.

Table 3.3. Bounding Minimum $\mathrm{K}_{\mathrm{d}}$ Values $(\mathrm{mL} / \mathrm{g}$ ) for Technetium (from Krupka and Serne 1998 and Bradbury and Van Loon 1998)

\begin{tabular}{|c|c|c|c|}
\hline \multirow{2}{*}{\multicolumn{2}{|c|}{ Cement Environment }} & \multicolumn{2}{|c|}{$\mathrm{K}_{\mathrm{d}}$ Values $(\mathrm{mL} / \mathrm{g})$} \\
\hline & & \multirow{2}{*}{$\begin{array}{c}\text { Krupka and } \\
\text { Serne (1998) } \\
0\end{array}$} & \multirow{2}{*}{$\begin{array}{c}\text { Bradbury and } \\
\text { Van Loon } \\
(1998)\end{array}$} \\
\hline \multirow{2}{*}{$\begin{array}{l}\text { I - Environment occurs immediately after cement hardens; } \\
\text { cement pore water has high } \mathrm{pH}(>12.5) \text {, high ionic strength, } \\
\text { and high } \mathrm{K} \text { and Na concentrations. }\end{array}$} & Oxidizing & & \\
\hline & Reducing & 1,000 & 1,000 \\
\hline \multirow{2}{*}{$\begin{array}{l}\text { II }- \text { Alkali metals are all dissolved, and cement pore water } \\
\mathrm{pH} \text { is controlled at } \sim 12.5 \text { by } \mathrm{Ca}(\mathrm{OH})_{2} \text { solubility. }\end{array}$} & Oxidizing & 0 & 1 \\
\hline & Reducing & 1,000 & 1,000 \\
\hline \multirow{2}{*}{$\begin{array}{l}\text { III - Concentration of } \mathrm{Ca}(\mathrm{OH})_{2} \text { has decreased and solubility } \\
\text { of } \mathrm{CSH} \text { (gel) controls cement pore water chemistry to a pH } \\
\text { of } \sim 10 \text { or less and low ionic strength. }\end{array}$} & Oxidizing & 0 & 0 \\
\hline & Reducing & 100 & 100 \\
\hline
\end{tabular}




\subsection{Iodine-129}

Iodine (I) (atomic number 53) is a member of the halogen group and can exist in six oxidation states $(-1$ to +7$)$. Iodine-129 was created as a byproduct of plutonium production in Hanford's nine production reactors via classical fission processes. Due to its long $t_{1 / 2}$ (15.7 million years) (Tuli 2004) and relatively unencumbered migration in subsurface environments (Cantrell et al. 2003; Um et al. 2004), it is a longterm risk driver in Hanford tank waste. The environmental behavior of iodine has been reviewed by others, such as Lieser and Steinkopff (1989), Whitehead (1984), Coughtrey et al. (1983), and Ames and Rai (1978). The geochemical processes affecting the mobility of iodine species in the Hanford vadose zone are discussed in detail in Cantrell et al. (2007b).

\subsubsection{Oxidation States}

Iodine can exist in the $-1,0,+1,+3,+5$, and +7 oxidation states; the -1 (iodide, $\mathrm{I}^{-}$), +5 (iodate, $\mathrm{IO}_{3}{ }^{-}$), and molecular $\mathrm{I}_{2}^{\circ}$ oxidation states most commonly are observed in aqueous environmental samples.

\subsubsection{Aqueous Speciation}

Figure 3.8 is an Eh-pH diagram that shows the dominant aqueous species of iodine predicted to present at $25^{\circ} \mathrm{C}$ and a total activity of $7.56 \times 10^{-9} \mathrm{M}$ dissolved iodine. The activities of the cations and complexing ligands used to calculate Figure 3.8 are from Table 3.1 and are discussed in Section 3.3. In most aqueous environments, iodine is present as the iodide ion, $\mathrm{I}^{-}$. The stability range of iodide extends over almost the entire $\mathrm{pH}$ and $\mathrm{Eh}$ range for the thermodynamic stability of water. In highly oxidizing environments, such as surface waters and some oxygenated shallow groundwaters, iodine may be present in the +5 oxidation state as the iodate ion, $\mathrm{IO}_{3}{ }^{-}$. Under oxidizing, acidic conditions $(\mathrm{pH}<\sim 2$ ), molecular $\mathrm{I}_{2}{ }^{0}(\mathrm{aq})$ may form from the reduction of iodate or the oxidation of iodide.

The volatilization of iodine from sediment to the atmosphere may occur as a result of both chemical and microbiological processes (Whitehead 1984). The chemical processes generally result in molecular iodine or hydrogen iodide, and the microbiological processes yield organic compounds, such as methyl iodide. Methyl iodide is not strongly retained by sediment components and is only slightly soluble in water (Whitehead 1984). Also, the organic carbon contents (e.g., fulvic acid) of sediments and/or microbial processes may affect the redox reactions of iodine in sediments. However, reactions with naturally occurring organic carbon, which is low (a couple tenths of a percent or less) in sediment at the Hanford Site, or with metal-reducing bacteria are not expected to be important processes affecting the redox behavior of iodine-129 in leachates from Hanford tank residual waste.

\subsubsection{Solubility}

Precipitation of iodine-containing solids is not likely to be an important process affecting the release of iodine-129 due to the low concentrations of iodine-129 and stable iodine isotope (iodine-127) in the leachates from tank residual waste and the high solubility of iodine-containing minerals. Iodine can be found as a primary component in some rare, naturally occurring minerals that are associated with evaporite and brine deposits (Doner and Lynn 1977; Johnson 1994). Iodide is commonly present in substitution for other halogen elements, such as chloride and bromide, whereas iodate is typically associated with sulfate- or nitrate-type minerals. However, such minerals are expected to be highly soluble and not likely present in residual tank wastes. 


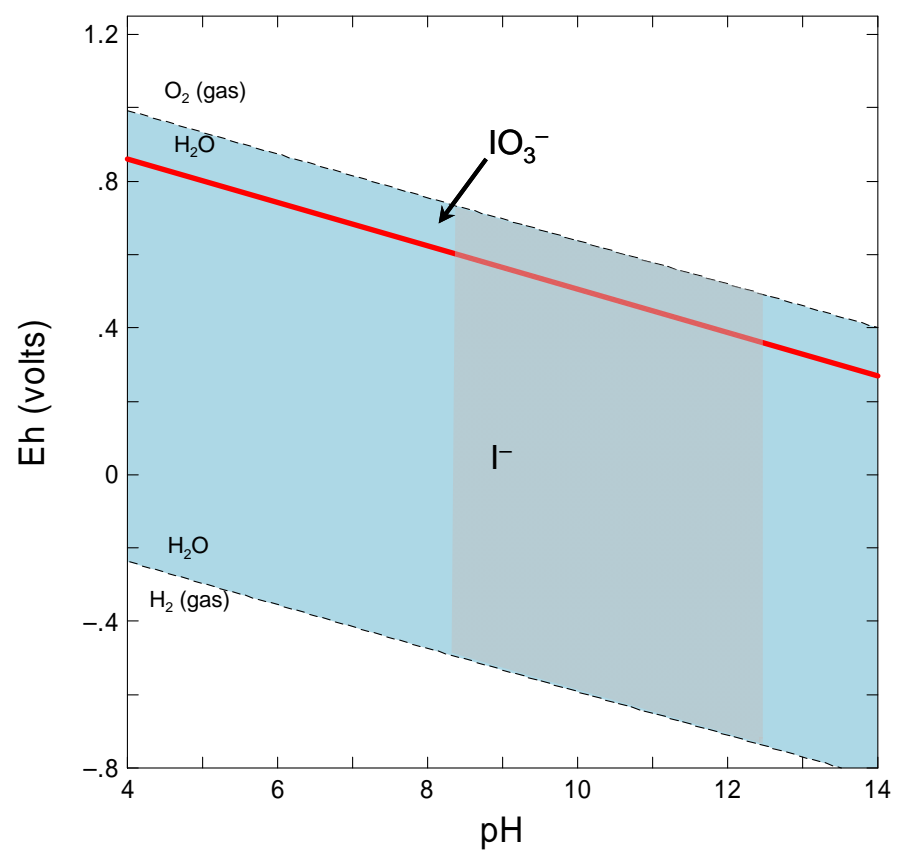

Figure 3.8. Dominant Aqueous Species of Iodine. Diagram was calculated at $25^{\circ} \mathrm{C}$ at a total activity of $7.56 \times 10^{-9} \mathrm{M}$ dissolved iodine and activities (effective concentrations) for other constituents as given in Table 3.1 .

\subsubsection{Adsorption}

A detailed review of iodine adsorption studies is given in EPA (2004). Iodine studies published before 1976 are reviewed in Ames and Rai (1978) and Onishi et al. (1981). As previously mentioned, iodine is typically present as an anion (either $\mathrm{I}^{-}$or $\mathrm{IO}_{3}^{-}$) in environmental samples. Therefore, conventional wisdom suggests that as an anion, its adsorption on cementitious materials and iron-oxide corrosion products will be negligible from $\mathrm{pH} 8$ to highly $\mathrm{pH}$ conditions and will increase as $\mathrm{pH}$ values become more acidic. The $K_{d}$ values listed in the compilation by Cantrell et al. (2003) for Hanford sediments generally indicate relatively low adsorption for iodide. Under typical Hanford Site groundwater conditions, $\mathrm{K}_{\mathrm{d}}$ values range from approximately 0 to $2 \mathrm{~mL} / \mathrm{g}$, with a range of 0 to $0.2 \mathrm{~mL} / \mathrm{g}$ being most typical.

Krupka and Serne (1998) summarize several studies on the incorporation of iodide and iodate species into cement and adsorption studies of these species onto crushed cement and concrete. The results of all these studies are in agreement in that there is some interaction between the cement paste and the iodine. For example, Allard et al. (1984) and Hoglund et al. (1985) present results from batch adsorption experiments of iodine onto seven types of concretes. The concretes included two OPCs, BFS, sulfateresistant, high-alumina, silica fume, and fly ash cements. All of the concretes used quartz sand ballast $(0.1$ to $0.3 \mathrm{~mm})$. The batch adsorption tests lasted for up to 6 months; small aliquots of solution were removed periodically for gamma energy analysis and $\mathrm{pH}$ measurement. The measured $\mathrm{K}_{\mathrm{d}}$ values for iodide increased slowly for the first several months and then remained steady for the remainder of the 6-month test. Iodide $\mathrm{K}_{\mathrm{d}}$ values ranged from 25 to $130 \mathrm{~mL} / \mathrm{g}$, with no obvious trend between tests that used "fresher" pore water with higher concentrations of alkali metals versus those that used "older" pore water with lower concentrations of alkali metals but higher concentrations of dissolved calcium. There was a slight increase in the $\mathrm{K}_{\mathrm{d}}$ value for the standard OPC blends over blends that contained the other 
additives. Allard et al. (1984) suggested that the apparent higher than expected iodine adsorption could be due to solubility limitations at the high calcium concentrations of the cement pore waters. Glasser and Atkins (1994) identify both CSH gel and calcium monosulfate aluminate as the phases that can retain iodine.

Based on the results of the available adsorption studies, bounding minimum $\mathrm{K}_{\mathrm{d}}$ values selected by Bradbury and Van Loon (1998) and Krupka and Serne (1998) for the adsorption of iodine onto cement/concrete are those listed in Table 3.4.

Table 3.4. Bounding Minimum $\mathrm{K}_{\mathrm{d}}$ Values $(\mathrm{mL} / \mathrm{g})$ for Iodine (from Krupka and Serne 1998 and Bradbury and Van Loon 1998)

\begin{tabular}{|c|c|c|c|}
\hline \multirow{2}{*}{\multicolumn{2}{|c|}{ Cement Environment }} & \multicolumn{2}{|c|}{$\mathrm{K}_{\mathrm{d}}$ Values $(\mathrm{mL} / \mathrm{g})$} \\
\hline & & \multirow{2}{*}{$\begin{array}{c}\text { Krupka and } \\
\text { Serne (1998) } \\
10\end{array}$} & \multirow{2}{*}{$\begin{array}{c}\begin{array}{c}\text { Bradbury and } \\
\text { Van Loon } \\
(1998)\end{array} \\
10\end{array}$} \\
\hline \multirow{2}{*}{$\begin{array}{l}\text { I - Environment occurs immediately after cement hardens; } \\
\text { cement pore water has high } \mathrm{pH}(>12.5) \text {, high ionic strength, } \\
\text { and high } \mathrm{K} \text { and } \mathrm{Na} \text { concentrations. }\end{array}$} & Oxidizing & & \\
\hline & Reducing & 10 & 10 \\
\hline \multirow{2}{*}{$\begin{array}{l}\text { II - Alkali metals are all dissolved, and cement pore water } \\
\mathrm{pH} \text { is controlled at } \sim 12.5 \text { by } \mathrm{Ca}(\mathrm{OH})_{2} \text { solubility. }\end{array}$} & Oxidizing & 5 & 10 \\
\hline & Reducing & 5 & 10 \\
\hline \multirow{2}{*}{$\begin{array}{l}\text { III - Concentration of } \mathrm{Ca}(\mathrm{OH})_{2} \text { has decreased and solubility } \\
\text { of } \mathrm{CSH} \text { (gel) controls cement pore water chemistry to a pH } \\
\text { of } \sim 10 \text { or less and low ionic strength. }\end{array}$} & Oxidizing & 1 & 1 \\
\hline & Reducing & 1 & 1 \\
\hline
\end{tabular}

\subsection{Chromium}

Chromium (Cr) (atomic number 24) is a member of Group VIB in the periodic classification of the elements. The sources of chromium in the SSTs are believed to be reagents used in reprocessing irradiated fuels (Anderson 1990) and corrosion of stainless steel process vessels and lines primarily within each plant (Agnew et al. 1997). The behavior of chromium in environmental systems has been reviewed extensively by Bartlett and Kimble (1976a, 1976b), Bartlett and James (1979), James and Bartlett (1983a, 1983b, 1983c), Rai et al. (1988), Palmer and Wittbrodt (1991), Richard and Bourg (1991), Palmer and Puls (1994), Davis and Olsen (1995), and Zachara et al. (2004). Ball and Nordstrom (1998) present a critical review of the thermodynamic properties for chromium metal and its aqueous ions, hydrolysis species, oxides, and hydroxides. The geochemical processes affecting the mobility of chromium in the Hanford vadose zone are discussed in detail in Cantrell et al. (2007b).

\subsubsection{Oxidation States}

Chromium occurs under natural conditions in the +3 and +6 oxidation states. Hexavalent chromium $\left(\mathrm{CrO}_{4}{ }^{2-}\right.$, chromate) is stable under strongly oxidizing conditions, and trivalent chromium and its hydrolysis products are stable under reducing and moderately oxidizing conditions. Dichromate $\left(\mathrm{Cr}_{2} \mathrm{O}_{7}{ }^{2-}\right)$ compounds are used in many industrial processes as oxidizing agents and may exist in the environment near discharge locations. Chromium(VI) tends to be soluble, forms anionic species, and can be very mobile (Nriagu and Nieboer 1988). Chromium(VI) is a strong oxidant and is rapidly reduced in the presence of such common electron donors as aqueous $\mathrm{Fe}(\mathrm{II})$, ferrous [ $\mathrm{Fe}(\mathrm{II})]$ iron minerals (e.g., magnetite $\left[\mathrm{Fe}_{3} \mathrm{O}_{4}\right]$, ilmenite $\left[\mathrm{FeTiO}_{3}\right]\left[\right.$ White and Hochella 1989], and pyrite $\left[\mathrm{FeS}_{2}\right]$ [Blowes and Ptacek 
1992]), reduced sulfur, and organic matter (Bartlett and Kimble 1976a; Nakayama et al. 1981). Microbes can catalyze these reactions. In contrast, $\mathrm{Cr}$ (III) tends to precipitate, form cationic dissolved species, and become immobile under moderately alkaline to slightly acidic conditions. The oxidation of $\mathrm{Cr}$ (III) by dissolved oxygen and manganese oxides has been verified in laboratory experiments. The rate of oxidation of $\mathrm{Cr}(\mathrm{III})$ by $\mathrm{O}_{2}$ is very slow (Van der Weijden and Reith 1982; Eary and Rai 1987), whereas oxidation by manganese oxides, such as manganite $(\gamma-\mathrm{MnOOH})$, has been determined experimentally to be fast (Johnson and Xyla 1991).

\subsubsection{Aqueous Speciation}

Figure 3.9 is an Eh-pH diagram that shows the dominant aqueous species of chromium predicted to be present at $25^{\circ} \mathrm{C}$ and a total activity of $3.16 \times 10^{-4} \mathrm{M}$ dissolved chromium. The activities of the cations and complexing ligands used to calculate Figure 3.9 are from Table 3.1 and are discussed in Section 3.3. Chromium(VI) has relatively simple hydrolysis behavior, forming primarily anionic species including $\mathrm{HCrO}_{4}{ }^{-}$(bichromate) and $\mathrm{CrO}_{4}{ }^{2-}$ (chromate) at $\mathrm{pH}$ values less and greater than 6.5 , respectively, and $\mathrm{Cr}_{2} \mathrm{O}_{7}{ }^{2-}$ (dichromate) at higher concentrations of dissolved chromium (Baes and Mesmer 1976; Palmer and Wittbrodt 1991; Richard and Bourg 1991). Chromium(VI) as chromate $\left(\mathrm{CrO}_{4}{ }^{2-}\right)$ is likely to be the dominant chromium species present in leachates from tank residual waste. Chromate predominates at higher Eh values $(>300 \mathrm{mV}$ at $\mathrm{pH} 8$ and $>-100 \mathrm{mV}$ at $\mathrm{pH} 12.5)$. At lower Eh values, the $\mathrm{Cr}$ (III) species are present at higher concentration than chromate, with the dominant species being dependent on $\mathrm{pH}$. For the $\mathrm{pH}$ range of interest to residual tank waste leachates (gray-shaded area in Figure 3.9), Cr(III) exists

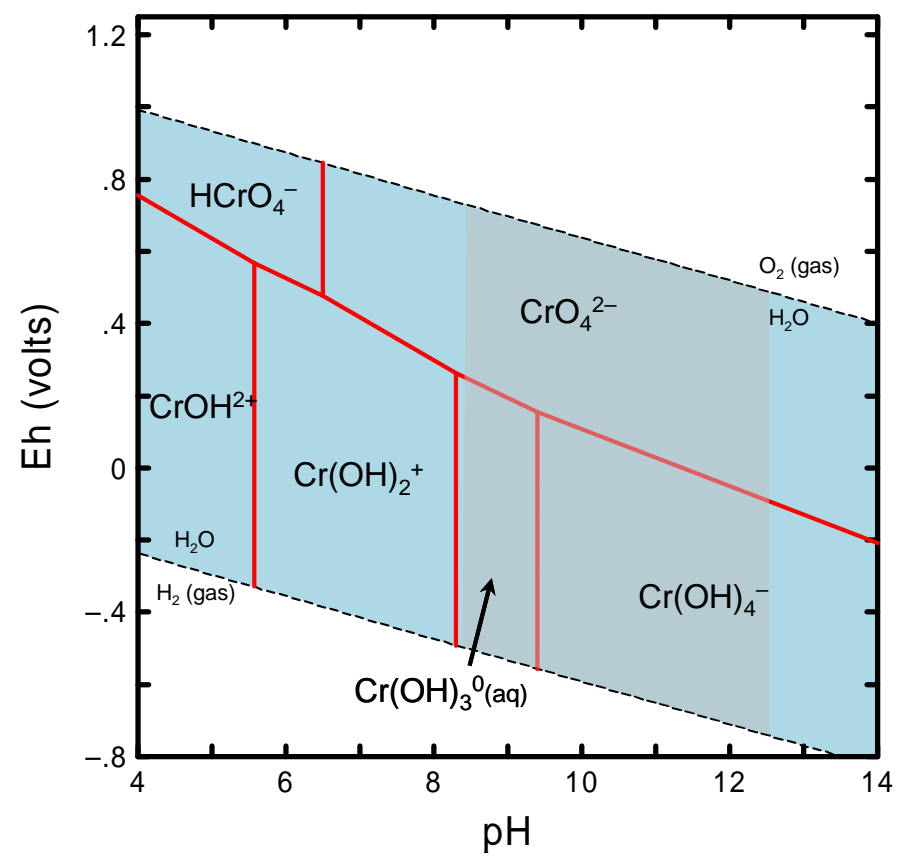

Figure 3.9. Eh-pH Diagram Showing Dominant Aqueous Species of Chromium. Diagram was calculated at $25^{\circ} \mathrm{C}$ at a total activity of $3.16 \times 10^{-4} \mathrm{M}$ dissolved chromium and activities (effective concentrations) for other constituents as given in Table 3.1. Eh-pH regions where precipitation of solids may occur have been suppressed in the calculations used to plot this figure but are shown in the next figure related to this contaminant. 
predominantly as the hydrolysis species $\mathrm{Cr}(\mathrm{OH})_{3}{ }^{0}(\mathrm{aq})$ and $\mathrm{Cr}(\mathrm{OH})_{4}{ }^{-}$with $\mathrm{Cr}(\mathrm{OH})_{4}{ }^{-}$predominating above a $\mathrm{pH}$ of $\sim 9.5$. At higher chromium concentrations, polynuclear species such as $\mathrm{Cr}_{2}(\mathrm{OH})_{2}{ }^{4+}$ and $\mathrm{Cr}_{3}(\mathrm{OH})_{4}{ }^{5+}$ can form slowly at $25^{\circ} \mathrm{C}$ (Baes and Mesmer 1976). Chromium(III) complexes with dissolved ligands such as fluoride, ammonia, and cyanide (Baes and Mesmer 1976).

\subsubsection{Solubility}

The concentration of dissolved $\mathrm{Cr}(\mathrm{VI})$ in the leachates from residual tank wastes is not expected to be affected by the precipitation of $\mathrm{Cr}(\mathrm{VI})$-containing mineral phases. Although several $\mathrm{Cr}(\mathrm{VI})$-containing minerals are known, they are very soluble and occur only at sites with very high dissolved chromium concentrations. Under oxidizing conditions where chromate is stable, total dissolved chromium concentrations can be much greater than $1 \mathrm{mg} / \mathrm{L}$ because of the high solubility of chromate minerals. Conversely, under more reducing conditions where $\mathrm{Cr}$ (III) minerals are stable, the total dissolved chromium concentration is typically much less than $1 \mathrm{mg} / \mathrm{L}$ because of the low solubility of $\mathrm{Cr}$ (III) minerals such as $\mathrm{Cr}(\mathrm{OH})_{3}$ and $(\mathrm{Fe}, \mathrm{Cr})(\mathrm{OH})_{3}(\mathrm{am})$. Rai et al. (1984) concluded that most $\mathrm{Cr}(\mathrm{III})$ solubility-controlling solids in nature are either $\mathrm{Cr}(\mathrm{OH})_{3}$ or $\mathrm{Cr}(\mathrm{III})$ coprecipitated with iron oxides. Sass and Rai (1987) determined that $\mathrm{Cr}$ (III) can precipitate with $\mathrm{Fe}(\mathrm{III})$ to form a solid solution, with the general composition $\mathrm{Cr}_{\mathrm{x}} \mathrm{Fe}_{1-\mathrm{x}}(\mathrm{OH})_{3}$ at $\mathrm{pH}$ values greater than 4. The Eh-pH diagram in Figure 3.10 for this system displays the large stability field of the amorphous $\mathrm{Cr}(\mathrm{OH})_{3}$ solid. The contact lines between this solid and dissolved $\mathrm{Cr}$ species are calculated for a total activity of $3.16 \times 10^{-4} \mathrm{M}(16.4 \mathrm{mg} / \mathrm{L})$ dissolved chromium. The activities of chromium and the other major cations and anions used to calculate Figure 3.10 are from Table 3.1 and are discussed in Section 3.3.

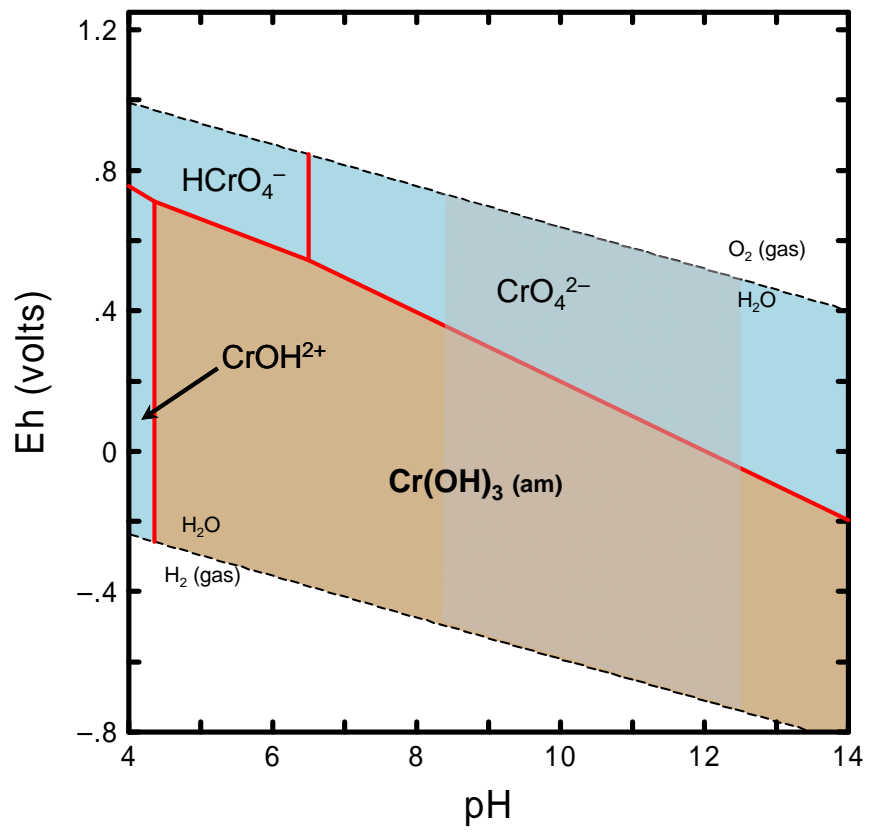

Figure 3.10. Eh-pH Diagram Showing the Stability Field of Amorphous $\mathrm{Cr}(\mathrm{OH})_{3}$. Diagram was calculated at $25^{\circ} \mathrm{C}$ at total activity of $3.16 \times 10^{-4} \mathrm{M}$ dissolved chromium and activities (effective concentrations) for other constituents as given in Table 3.1. 


\subsubsection{Adsorption}

EPA (1999b) provides a detailed review of the available adsorption information for $\mathrm{Cr}(\mathrm{VI})$. Because $\mathrm{Cr}(\mathrm{VI})$ exists primarily as the anion $\mathrm{CrO}_{4}{ }^{2-}$ in most oxic sediment systems, $\mathrm{Cr}$ (VI) does not adsorb to any significant extent under most geochemical conditions. In their compilation of $\mathrm{K}_{\mathrm{d}}$ values measured with Hanford sediments, Cantrell et al. (2003) found only a limited number of studies of $\mathrm{Cr}$ (VI) adsorption. The measured $\mathrm{K}_{\mathrm{d}}$ values for $\mathrm{Cr}(\mathrm{VI})$ on Hanford sediments range from 0 to $1 \mathrm{~mL} / \mathrm{g}$, with typical values being zero or close to zero. Cantrell et al. (2003) concluded that adsorption of $\mathrm{Cr}(\mathrm{VI})$ is very low to nonexistent under normal Hanford groundwater conditions unless conditions are acidic. The adsorption of $\mathrm{Cr}(\mathrm{VI})$ is expected to increase with decreasing $\mathrm{pH}$ because dissolved $\mathrm{Cr}(\mathrm{VI})$ exists as an anionic species and variably charged sorption sites on geologic solids become more positive at low $\mathrm{pH}$ and capable of attracting anions.

Most information on $\mathrm{Cr}(\mathrm{VI})$ adsorption in the general literature comes from studies with pure mineral phases (Griffin et al. 1977; Davis and Leckie 1980; Leckie et al. 1980). These studies suggest that $\mathrm{Cr}(\mathrm{VI})$ adsorbs strongly to gibbsite $\left(\alpha-\mathrm{Al}_{2} \mathrm{O}_{3}\right)$ and amorphous iron oxide $\left[\mathrm{Fe}_{2} \mathrm{O}_{3} \cdot \mathrm{H}_{2} \mathrm{O}(\mathrm{am})\right]$ at low to medium $\mathrm{pH}$ values (i.e., $\mathrm{pH} 2$ to 7$)$ and adsorbs weakly to silica $\left(\mathrm{SiO}_{2}\right)$ at all but very low $\mathrm{pH}$ values. The presence of competing and, less commonly, complexing ions may significantly alter chromate adsorption. Phosphate exhibits a greater competitive effect on $\mathrm{CrO}_{4}{ }^{2-}$ adsorption (MacNaughton 1977), reducing sorption by around $50 \%$ when present at equal normality.

Adsorption of $\mathrm{Cr}$ (III) to sediments has received only a nominal amount of research attention, possibly because sorption of $\mathrm{Cr}$ (III) is commonly attributed to precipitation processes for $\mathrm{Cr}$ (III)-containing solids as discussed above. The limited number of published studies infer that $\mathrm{Cr}$ (III), like other +3 cationic metals, is strongly and specifically absorbed by sediment iron and manganese oxides (Korte et al. 1976). However, adsorption of $\mathrm{Cr}(\mathrm{III})$ at $\mathrm{pH}$ conditions expected for leachate from the tank residual waste system should be low and decrease with increasing $\mathrm{pH}$ above $\mathrm{pH} 9.4$ because the neutral $\mathrm{Cr}(\mathrm{OH})_{3}{ }^{0}(\mathrm{aq})$ and anionic $\mathrm{Cr}(\mathrm{OH})_{4}{ }^{-}$species calculate to be the dominant $\mathrm{Cr}(\mathrm{III})$ aqueous species at these $\mathrm{pH}$ conditions (see gray-shaded area in Figure 3.9).

Krupka and Serne (1998) and Bradbury and Van Loon (1998) did not review the adsorption of chromium onto cementitious materials. An online search of the journal literature published since 1995 did not identify any studies of chromium adsorption onto cement. In the absence of such data and knowing the sorption and solubility behavior of $\mathrm{Cr}(\mathrm{VI})$ and $\mathrm{Cr}(\mathrm{III})$ in geochemical systems, it is recommended based on expert judgment that the bounding $\mathrm{K}_{\mathrm{d}}$ values listed in Table 3.3 for technetium under oxidizing and reducing conditions also be used for $\mathrm{Cr}(\mathrm{VI})$ (oxidizing conditions) and $\mathrm{Cr}(\mathrm{III})$ (reducing conditions) at the corresponding cement environments.

\subsection{Nitrate}

Nitrogen (N) (atomic number 7) is the lightest element of Group 5 in the periodic classification of the elements. The behavior of nitrogen species, such as nitrate, in aqueous, sediment, and geochemical systems has been discussed by Lindsay (1979), Lindsay et al. (1981), Stumm and Morgan (1981), Hem (1986), and others. The geochemical processes affecting the mobility of nitrate in the Hanford vadose zone are discussed in detail in Cantrell et al. (2007b). 


\subsubsection{Oxidation States}

Nitrogen can exist in several oxidation states from +6 to -3 in geochemical environments. In natural waters, nitrogen exists primarily in the +5 (nitrate, $\mathrm{NO}_{3}{ }^{-}$), +3 (nitrite, $\mathrm{NO}_{2}{ }^{-}$), 0 [ $\mathrm{N}_{2}$ (gas)], and -3 (ammonium, $\mathrm{NH}_{4}{ }^{+}$) oxidation states. The rate at which equilibrium is reached among the different redox states of nitrogen is very slow in abiotic systems because of the high activation energies associated with nitrogen redox reactions (Lindsay et al. 1981). In leachates that have contacted tank residual waste, nitrogen will likely be present as the highly mobile $\mathrm{NO}_{3}{ }^{-}$(nitrate) species.

\subsubsection{Aqueous Speciation}

Figure 3.11 shows the dominant aqueous species of nitrogen predicted to be present at $25^{\circ} \mathrm{C}$ and a total activity of $1.63 \times 10^{-3} \mathrm{M}$ dissolved nitrogen. The activities of the cations and complexing ligands used to calculate Figure 3.11 are from Table 3.1. The stability diagram was calculated assuming that $\mathrm{N}_{2}$ (gas) is unreactive and the aqueous system represented in Figure 3.11 is not in equilibrium with $\mathrm{N}_{2}$ (gas). Figure 3.11 shows that $\mathrm{NO}_{3}{ }^{-}$(nitrate) is the dominant nitrogen species over the entire $\mathrm{pH}$ range for oxic systems. Under mildly reducing conditions, there are also two narrow Eh-pH regions where $\mathrm{N}(\mathrm{III})$ as $\mathrm{HNO}_{2}{ }^{0}$ (aq) (very acidic conditions) and $\mathrm{NO}_{2}{ }^{-}$(near-neutral to very basic $\mathrm{pH}$ conditions) are predicted to be stable. Under more strongly reducing conditions, nitrogen as the cationic $\mathrm{NH}_{4}{ }^{+}$and neutral $\mathrm{NH}_{3}{ }^{0}$ (aq) species are the dominant aqueous species at $\mathrm{pH}$ values less and greater than approximately 9.2 , respectively.

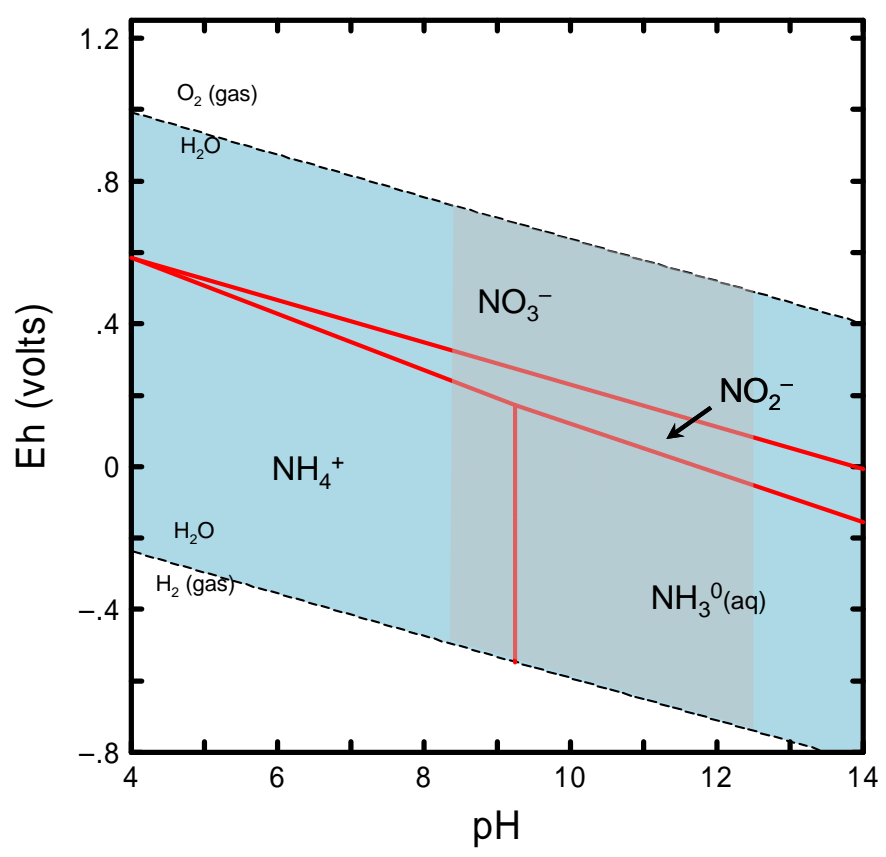

Figure 3.11. Dominant Aqueous Species of Nitrogen. Diagram was calculated at $25^{\circ} \mathrm{C}$ at a total activity of $1.63 \times 10^{-3} \mathrm{M}$ dissolved nitrogen and activities (effective concentrations) for other constituents as given in Table 3.1. 


\subsubsection{Solubility}

Nitrate-containing minerals such as nitratine (soda niter, $\left.\mathrm{NaNO}_{3}\right)$ and niter $\left(\mathrm{KNO}_{3}\right)$ do occur in some geochemical systems. These minerals are highly soluble and restricted in occurrence to highly concentrated nitrate systems, such as evaporite deposits. Although nitratine has been identified in wastes in preretrieval Hanford tank wastes, such phases are not expected to precipitate from leachates from tank residual waste.

Bickmore et al. (2001) recently reported the formation of a nitrate form of cancrinite $\left[\mathrm{Na}_{8} \mathrm{Si}_{6} \mathrm{Al}_{6} \mathrm{O}_{24}\left(\mathrm{NO}_{3}\right)_{2} \cdot 4 \mathrm{H}_{2} \mathrm{O}\right]$ in studies of mineral precipitation on quartz sand reacted with simulated Hanford tank solutions. Bickmore et al. (2001) conducted a set of batch experiments with low solid-tosolution ratios in which high $\mathrm{pH}$, high $\mathrm{NaNO}_{3}$ solutions with dissolved aluminum were reacted with quartz sand at $89^{\circ} \mathrm{C}$. Because cancrinite exhibits cation-exchange properties, investigators have speculated on the potential effect that precipitated cancrinite might have on sequestration (i.e., sorption) of contaminants of interest. As part of an extensive study to develop a thermodynamic framework to accurately describe the formation of $\mathrm{NO}_{3}$ cancrinite and $\mathrm{NO}_{3}$ sodalite relative to high-level waste (HLW) stored in underground storage tanks, Jove Colon et al. (2004) also investigated the partitioning and ion exchange properties of these zeolitic phases with respect to select radionuclides and RCRA metal species. Their results indicated the possible of uptake of dissolved $\mathrm{Cs}^{+}$by $\mathrm{NO}_{3}$ cancrinite but did not show any significant decrease in the dissolved concentrations $\mathrm{ReO}_{4}{ }^{-}$(used as a surrogate for $\mathrm{TcO}_{4}{ }^{-}$), $\mathrm{SeO}_{4}{ }^{2-}$, or $\mathrm{I}^{-}$. Research related to solubility, kinetics of precipitation, and sorption properties of cancrinite relative to the interaction of simulated Hanford tank wastes and vadose zone sediments continues. However, it is too early to judge the extent to which cancrinite precipitation might affect the mobility of contaminants in such environments or in leachates from tank residual waste.

\subsubsection{Adsorption}

Nitrate does not readily adsorb on minerals under near-neutral and slightly alkaline $\mathrm{pH}$ conditions common in sediment systems and is typically not included in most databases of $\mathrm{K}_{\mathrm{d}}$ values such as Thibault et al. (1990). Cantrell et al. (2003) identified only one study in which $\mathrm{K}_{\mathrm{d}}$ values for nitrate adsorption was measured using Hanford sediment. The results from this single study of Serne et al. (1993) indicate that nitrate adsorption is essentially zero (i.e., $K_{d}=0$ ).

Nitrate $\left(\mathrm{NO}_{3}^{-}\right)$and nitrite $\left(\mathrm{NO}_{2}^{-}\right)$are typically assigned $\mathrm{K}_{\mathrm{d}}$ values of $0 \mathrm{~mL} / \mathrm{g}$. As anions, adsorption is expected to occur under acidic conditions, decrease with increasing $\mathrm{pH}$ values, and be essentially nil at slightly to highly basic $\mathrm{pH}$ conditions. Ammonium $\left(\mathrm{NH}_{4}{ }^{+}\right)$cations are highly adsorbed to mineral surfaces through cation exchange and may be present as a contaminant leached from some of the tank wastes. However, it has not been identified as a long-term threat to groundwater from the closed tanks (DOE ORP 2006).

Krupka and Serne (1998) and Bradbury and Van Loon (1998) did not review the adsorption of nitrate onto cementitious materials. An online search of the journal literature published since 1995 did not identify any studies of nitrate adsorption onto cement. In the absence of such data and because the sorption of nitrate in geochemical systems at basic $\mathrm{pH}$ conditions is essentially zero, it is recommended based on expert judgment that the bounding $K_{d}$ value of $0 \mathrm{~mL} / \mathrm{g}$ be used for nitrate under oxidizing and reducing conditions for the three cement environments. 


\subsection{Residual Waste Testing and Results of Leaching Tests}

Various analyses and tests have been conducted on residual tank waste samples to identify phases containing contaminants of interest. These contaminants can occur as a primary component of a mineral phase or as a trace component of a mineral in which other elements make up the primary components of that phase. Analytical characterization techniques have been applied that could potentially identify the presence of the contaminant as a primary or trace constituent in the solids comprising the waste. The techniques used by the PNNL Residual Tank Waste Contaminant Release Project include XRD, SEM/EDS, and synchrotron-based x-ray techniques. These methods were used to identify and characterize the solid phases in the unaltered residual waste samples collected at the end of the retrieval process and waste samples remaining at the end of laboratory leach tests. The results of the analyses of these samples are discussed in Section 2.

Aliquots of residual waste collected from retrieved tanks were tested by the Residual Tank Waste Contaminant Release Project in the laboratory by single-contact and periodic replenishment extraction tests using various solutions to determine the leachability of constituents from the residual waste. These tests were conducted at solution-to-solid ratios of approximately 100:1 in polypropylene centrifuge tubes sealed to prevent exchange of $\mathrm{CO}_{2}$ from the atmosphere. The water extraction data were combined with selective extractions and solubility experiment results to identify solids in equilibrium with the leachates. These data were combined with XRD and SEM/EDS analysis of the leached waste solids to understand the leaching process and develop contaminant release models. This section provides a brief discussion of the leach test methods and results for the COIs.

\subsection{Chemical and Solid Phase Analyses of Tank Waste}

Standard bulk powder XRD techniques were used to identify crystalline phases present. This technique is limited to crystalline phases with concentrations in the sample greater than approximately 1 to $5 \mathrm{wt} \%$.

SEM/EDS techniques were used to identify morphological characteristics of the particles in the waste samples and determine elemental composition at selected locations on these particles. The areas of interest interrogated by EDS are typically a few micrometers in depth (depending on density of the phase and the accelerating voltage used for SEM analyses) and from submicrometer to 10 micrometers width in surface area. To obtain quantitative elemental analysis by EDS, the sample must be flat and considered homogeneous through the depth of the incident electron beam. This is not possible for the waste samples and, as a result, elemental compositions determined by EDS are qualitative and have large uncertainties. In addition, EDS analyses are limited to elements with atomic weights heavier than boron.

Various single-contact and periodic replenishment leach tests using three extraction solutions were conducted to determine the leachability of constituents from residual waste. The periodic replenishment tests generally consisted of six stages of sequential extraction of residual waste samples for periods of 1 to 82 days. The three extraction solutions used were DDI water, $\mathrm{Ca}(\mathrm{OH})_{2}$-saturated solution, and $\mathrm{CaCO}_{3}$-saturated solution. The $\mathrm{Ca}(\mathrm{OH})_{2}$-saturated solution was used to simulate a pore water within a fresh cement, and $\mathrm{CaCO}_{3}$-saturated solution was used to simulate a leachant produced by aged cement or a typical Hanford vadose zone pore water. The impact of silica expected to also leach from the concrete 
is not specifically dealt with in this report. In most cases, the extraction tests were conducted separately for each of the three leachant solutions. However, in the case of C-106 residual waste, the cement stimulant extractions were conducted by first conducting the six-stage series of $\mathrm{Ca}(\mathrm{OH})_{2}$ leaches followed by the six-stage series of $\mathrm{CaCO}_{3}$ leaches. In addition to determining the empirical leachability of various contaminants and other constituents in the waste, geochemical modeling of the compositions of the leachates was used to evaluate if solution concentrations were limited by the solubility of one or more solid phases. The utility of geochemical modeling is limited to phases that come to equilibrium within the extraction contact period, whose solubility and concentrations are such that they do not completely dissolve in the extraction fluid, and for which thermodynamic constants are available.

Selective extraction tests were sometimes conducted on the residual waste solids to identify the relative amounts of contaminants of interest that were associated with iron, aluminum, and manganese oxyhydroxide phases. These tests are described in Deutsch et al. (2007a). Although these tests are designed to be selective for various target phases, the results were generally not as selective as intended. Dissolution of non-target phases can sometimes confound the interpretation of the results.

Specially designed empirical solubility experiments also were conducted with C-203 residual waste in an attempt to identify solubility-controlling uranium phases. As with the single-contact and periodic replenishment extractions tests, application of the geochemical modeling to the solution compositions from these solubility experiments is similarly limited to phases that come to equilibrium within the extraction contact period and whose solubility and concentrations are such that they do not completely dissolve in the extraction fluid.

\subsection{Contaminants of Interest in C-103 Residual Waste}

No solid phases containing the COIs iodine or nitrate were detected by bulk XRD or SEM/EDS analyses of the $\mathrm{C}-103$ residual waste samples. If iodine or nitrate is preferentially concentrated in a distinct solid phase in the $\mathrm{C}-103$ residual waste, then the COI concentration in the host phase is likely too low for detection by EDS, or the host phase may also be amorphous or present at concentrations too low for detection by XRD.

\subsubsection{Uranium}

The average uranium concentration measured in tank C-103 residual waste is $3,730 \mu \mathrm{g} / \mathrm{g}$ dry wt (0.37\%) (Table 2.2; Cantrell et al. 2007a). This average was determined from three samples (19845, 19849 and 19850). SEM/EDS results (Section 2.2.3.1) indicated that uranium is present in the unleached and leached $\mathrm{C}-103$ samples as one or more discrete phases. The most common uranium phase appears to be a uranium oxide (probably hydrated). A less common uranium phase was composed of Ca-Na-U oxide. No crystalline uranium mineral phases were detected by XRD analysis, with the possible exception of rabejacite. However, rabejacite $\left[\mathrm{Ca}\left(\mathrm{UO}_{2}\right)_{4}\left(\mathrm{SO}_{4}\right)_{2}(\mathrm{OH})_{6} \cdot 6 \mathrm{H}_{2} \mathrm{O}\right]$ was not consistent with the $\mathrm{SEM} / \mathrm{EDS}$ results because sulfur was never detected at greater than a few tenths of a weight percent in any of the uranium-containing particles. Trace concentrations of uranium also were sometimes detected by SEM/EDS in the iron oxide/hydroxide particles. Hematite was identified by XRD as possibly present in the $\mathrm{C}-103$ residual waste samples.

Table 4.1 lists the dissolved concentrations of uranium present for each of the leach tests conducted on the three samples. These results are discussed in detail in Cantrell et al. (2007a). It is believed that 
Table 4.1. Tank C-103 Leach Test Results for Uranium (concentration units are $\mu \mathrm{g} / \mathrm{L}$ ) (from Cantrell et al. 2007a)

\begin{tabular}{|c|c|c|c|c|c|c|c|c|c|}
\hline \multirow[b]{2}{*}{ Sample ID } & \multicolumn{3}{|c|}{ DDI Water } & \multicolumn{3}{|c|}{$\mathrm{Ca}(\mathrm{OH})_{2}$} & \multicolumn{3}{|c|}{$\mathrm{CaCO}_{3}$} \\
\hline & 19845 & 19849 & 19850 & 19845 & 19849 & 19850 & 19845 & 19849 & 19850 \\
\hline $\mathrm{pH}$ & $5.03-9.04$ & $6.00-8.23$ & $6.10-7.90$ & $11.0-12.1$ & $10.7-11.8$ & $11.3-11.7$ & $6.28-8.81$ & $6.92-7.44$ & $7.15-11.9$ \\
\hline \multicolumn{10}{|c|}{ Single-Contact Tests $^{(\mathrm{a})}$} \\
\hline 1 month & 2,060 & 2,700 & 2,220 & $(0.020)$ & $(0.136)$ & $(0.520)$ & 1,880 & 1,860 & 4,050 \\
\hline 1 month (dup) & 2,120 & 2,030 & 2,690 & $(0.178)$ & $(0.162)$ & $(0.385)$ & 2,150 & 1,660 & 2,090 \\
\hline \multicolumn{10}{|c|}{ Sequential-Contact Tests } \\
\hline Stage $1(1 \mathrm{~d})$ & 652 & 150 & 1,810 & $(0.705)$ & $(1.26)$ & $(1.09)$ & 2,170 & 1,860 & $(5.95)$ \\
\hline Stage 1 (dup) & 694 & 154 & 2,000 & $(0.082)$ & $(1.98)$ & $(1.78)$ & 982 & 2,770 & $(6.65)$ \\
\hline Stage 2 (1d) & $(43.0)$ & 99.6 & $(27.9)$ & $(0.029)$ & $(0.140)$ & $(0.136)$ & 372 & 577 & 105 \\
\hline Stage 2 (dup) & 113 & 80.7 & $(26.4)$ & $(0.080)$ & $(0.104)$ & $(0.064)$ & 437 & 651 & 143 \\
\hline Stage $3(3 d)$ & 80.3 & 74.6 & 71.6 & $(0.016)$ & $(0.011)$ & $(0.116)$ & 426 & 455 & 220 \\
\hline Stage 3 (dup) & 72.0 & 112 & $(46.7)$ & $(0.127)$ & $(0.196)$ & $(0.156)$ & 526 & 410 & 2,320 \\
\hline Stage 4 (1d) & 74.2 & 65.7 & 79.8 & $(0.243)$ & $(0.129)$ & $(0.263)$ & 523 & 795 & 1,950 \\
\hline Stage 4 (dup) & 86.0 & 72.6 & 73.9 & $(0.143)$ & $(0.021)$ & $(0.280)$ & 718 & 854 & 1,920 \\
\hline Stage 5 (1d) & 51.6 & 122 & 53.2 & $(0.142)$ & $(0.002)$ & $(0.040)$ & 437 & 340 & 1,660 \\
\hline Stage 5 (dup) & 57.0 & 79.2 & 134 & $(0.011)$ & $(0.001)$ & $(0.004)$ & 629 & 326 & 1,330 \\
\hline Stage 6 (30d) & 479 & 1,220 & 431 & $(0.236)$ & $(0.321)$ & $(0.432)$ & 626 & 408 & 1,690 \\
\hline Stage 6 (dup) & 533 & 203 & 545 & $(0.005)$ & $(0.214)$ & $(0.031)$ & 798 & 1,520 & 1,890 \\
\hline
\end{tabular}

$\mathrm{CaCO}_{3}$-leach Stage 119850 sample was inadvertently extracted with the $\mathrm{Ca}(\mathrm{OH})_{2}$ leachant rather than the $\mathrm{CaCO}_{3}$ solution (see Cantrell et al. 2007a). Therefore, the results for Stages 1 through 6 of the $\mathrm{CaCO}_{3}$ leaches for sample 19850 are grayed-out and not included for discussion here. Uranium was measured above its quantitation limit only in the DDI and $\mathrm{CaCO}_{3}$ extracts. For the DDI water and $\mathrm{CaCO}_{3}$ extractants, the uranium concentrations in the 1-month single-contact extracts were typically significantly higher than those of sequential-contact tests. These results suggest that the lower contact times of the sequential-contact tests are not sufficient to reach equilibrium with solubility-controlling phases.

The DDI water extracts had the high concentrations of extractable uranium, with concentrations as high as $2,700 \mu \mathrm{g} / \mathrm{L} \mathrm{U}$. Because significant carbonate concentrations were measured in the DDI water extracts, formation of aqueous carbonate complexes significantly increased the solubility of uranium phases in the DDI extracts. Except for Stage 1 of sample 19850, the uranium concentrations in the sequential-contact extracts were significantly less than those of the 1-month single-contact extracts. A significant rebound in the uranium concentrations was observed in the Stage 6 (30 day) extraction. Geochemical modeling of the 1-month single-contact experiments indicate that these extracts are near equilibrium with schoepite. These results suggest that the short contact periods used for Stages 1 through 5 were not sufficient to reach equilibrium and that the dominant uranium phase in the C-103 residual waste may be schoepite.

The uranium concentrations in the $\mathrm{Ca}(\mathrm{OH})_{2}$ extracts are dramatically lower than those of the other two extracts, with a peak concentration of (1.98) $\mu \mathrm{g} / \mathrm{L}$ observed in one of the Stage 1 extracts. A general decrease in $\mathrm{U}$ concentrations was observed in the $\mathrm{Ca}(\mathrm{OH})_{2}$ extracts from Stages 2 and 5, with a possible rebound effect in Stage 6. These results suggest that a secondary uranium phase of lower solubility may have formed during contact with the $\mathrm{Ca}(\mathrm{OH})_{2}$ extracts. Note that the $\mathrm{pH}$ values of these extracts $(\mathrm{pH} 10.7$ 
to 12.1) were much higher than those for the DDI water (pH 5.0 to 9.0) and $\mathrm{CaCO}_{3}$ extracts ( $\mathrm{pH} 6.3$ to 8.8), which may have resulted in the formation of a uranium phase with a very low solubility. The identity of this possible phase has not been established.

The highest extractable uranium concentrations measured in all the extracts occurred in the 1-month single-contact $\mathrm{CaCO}_{3}$ extracts, with a concentration as high as $4,050 \mu \mathrm{g} / \mathrm{L}$ uranium. Formation of aqueous carbonate complexes significantly increases the solubility of uranium phases and is the likely reason for the high dissolved uranium in the $\mathrm{CaCO}_{3}$ extracts. The highest uranium concentrations occur in the 1 month and Stage 1 of the sequential-contact tests. Stages 2 through 5 had uranium concentrations that were significantly less than these extracts, while Stage 6 exhibited a modest rebound effect. Geochemical modeling of the 1-month single-contact experiments indicates that the $\mathrm{CaCO}_{3}$ extracts are near equilibrium with schoepite $\left(\mathrm{UO}_{3} \bullet \mathrm{H}_{2} \mathrm{O}\right)$. These results again suggest that the short contact periods used for Stages 1 through 5 were not sufficient to reach equilibrium and that the dominant uranium phase in the $\mathrm{C}-103$ residual waste is schoepite.

\subsubsection{Technetium-99}

Technetium-99 was measured at an average concentration of $0.23 \mu \mathrm{g} / \mathrm{g}$-dry wt in tank C-103 residual waste (see Table 2.2 in Cantrell et al. [2007a]). This concentration is too low for detection of discrete crystalline technetium-containing phases by XRD analysis, but technetium was detected in three Fe oxide/hydroxide particles analyzed by SEM/EDS at concentrations ranging from $0.6 \%$ to $1.0 \%$ (see discussion in Section 2.2.3.1)

Technetium-99 concentrations measured in the C-103 extracts are shown in Table 4.2. The concentrations of all the extract solutions are low, with only the 1-month single-contact extracts and a few

Table 4.2. Tank C-103 Leach Test Results for Technetium-99 (concentration units are $\mu \mathrm{g} / \mathrm{L}$ ) (from Cantrell et al. 2007a)

\begin{tabular}{|c|c|c|c|c|c|c|c|c|c|}
\hline \multirow[b]{2}{*}{ Sample ID } & \multicolumn{3}{|c|}{ DDI Water } & \multicolumn{3}{|c|}{$\mathrm{Ca}(\mathrm{OH})_{2}$} & \multicolumn{3}{|c|}{$\mathrm{CaCO}_{3}$} \\
\hline & 19845 & 19849 & 19850 & 19845 & 19849 & 19850 & 19845 & 19849 & 19850 \\
\hline $\mathrm{pH}$ & $5.03-9.04$ & $6.00-8.23$ & $6.10-7.90$ & $11.0-12.1$ & $10.7-11.8$ & $11.3-11.7$ & $6.28-8.81$ & $6.92-7.44$ & 7.15-11.9 \\
\hline \multicolumn{10}{|c|}{ Single-Contact Tests ${ }^{(a)}$} \\
\hline 1 month & 0.231 & 0.144 & 0.136 & 0.180 & 0.142 & 0.186 & 0.119 & 0.155 & 0.104 \\
\hline 1 month (dup) & 0.160 & 0.118 & 0.120 & 0.146 & 0.155 & 0.148 & 0.121 & 0.121 & 0.101 \\
\hline \multicolumn{10}{|c|}{ Sequential-Contact Tests } \\
\hline Stage $1(1 \mathrm{~d})$ & 0.121 & 0.103 & $(0.095)$ & 0.113 & $(0.098)$ & $(0.073)$ & 0.119 & $(0.087)$ & 0.106 \\
\hline Stage 1 (dup) & 0.120 & $(0.081)$ & 0.101 & 0.123 & 0.109 & $(0.099)$ & $(0.095$ & 0.121 & 0.109 \\
\hline Stage $2(1 d)$ & $<0.100$ & $<0.100$ & $<0.100$ & $<0.100$ & $<0.100$ & $<0.100$ & $<0.100$ & $<0.100$ & $<0.100$ \\
\hline Stage 2 (dup) & $<0.100$ & $<0.100$ & $<0.100$ & $<0.100$ & $<0.100$ & $<0.100$ & $<0.100$ & $<0.100$ & $<0.100$ \\
\hline Stage 3 (3d) & $<0.100$ & $<0.100$ & $<0.100$ & $<0.100$ & $<0.100$ & $<0.100$ & $<0.100$ & $<0.100$ & $<0.100$ \\
\hline Stage 3 (dup) & $<0.100$ & $<0.100$ & $<0.100$ & $<0.100$ & $<0.100$ & $<0.100$ & $<0.100$ & $<0.100$ & $<0.100$ \\
\hline Stage 4 (1d) & $<0.100$ & $<0.100$ & $<0.100$ & $<0.100$ & $<0.100$ & $<0.100$ & $<0.100$ & $<0.100$ & $<0.100$ \\
\hline Stage 4 (dup) & $<0.100$ & $<0.100$ & $<0.100$ & $<0.100$ & $<0.100$ & $<0.100$ & $<0.100$ & $<0.100$ & $<0.100$ \\
\hline Stage 5 (1d) & $<0.100$ & $<0.100$ & $<0.100$ & $<0.100$ & $<0.100$ & $<0.100$ & $<0.100$ & $<0.100$ & $<0.100$ \\
\hline Stage 5 (dup) & $<0.100$ & $<0.100$ & $<0.100$ & $<0.100$ & $<0.100$ & $<0.100$ & $<0.100$ & $<0.100$ & $<0.100$ \\
\hline Stage $6(30 d)$ & $(0.010)$ & $(0.015)$ & $(0.002)$ & $(0.070)$ & $(0.049)$ & $(0.059)$ & $<0.100$ & $<0.100$ & $<0.100$ \\
\hline Stage 6 (dup) & $(0.017)$ & $(0.002)$ & $(0.001)$ & $(0.071)$ & $(0.060)$ & $(0.068)$ & $<0.100$ & $<0.100$ & $<0.100$ \\
\hline
\end{tabular}


of the Stage 1 sequential contacts with concentrations above the EQL. Differences in the technetium-99 extractability between the three leachate solutions are minor. The highest technetium-99 concentration measured in the leachants was $0.23 \mu \mathrm{g} / \mathrm{L}$.

\subsubsection{Chromium}

Chromium was measured at a total concentration of $193 \mu \mathrm{g} / \mathrm{g}$ dry wt. in tank C-103 residual waste (see Table 2.2 in Cantrell et al. [2007a]). No crystalline chromium mineral phases were detected by XRD analysis. SEM/EDS analysis indicated that when hromium was detected, it was associated with the iron oxides/hydroxides.

Chromium concentrations measured in the C-103 extracts are shown in Table 4.3. Measurable concentrations were found consistently only in the $\mathrm{Ca}(\mathrm{OH})_{2}$ extracts. The extracts with longer contact times (1-month single-contact and Stage 6 of the sequential-contact test) have very low concentrations (below the quantitation limit) and Stages 2 through 5 have chromium concentrations that are consistently near $15 \mu \mathrm{g} / \mathrm{L}$. This is unusual behavior relative to the other COIs and may be related to its association with iron. The highest chromium concentration was measured in the DDI 1-month single-contact test for sample $19850(37.5 \mu \mathrm{g} / \mathrm{L})$.

Table 4.3. C-103 Leach Test Results for Chromium (based on ICP-MS results) (concentration units are $\mu \mathrm{g} / \mathrm{L})$ (from Cantrell et al. 2007a)

\begin{tabular}{|c|c|c|c|c|c|c|c|c|c|}
\hline \multirow[b]{2}{*}{ Sample ID } & \multicolumn{3}{|c|}{ DDI Water } & \multicolumn{3}{|c|}{$\mathrm{Ca}(\mathrm{OH})_{2}$} & \multicolumn{3}{|c|}{$\mathrm{CaCO}_{3}$} \\
\hline & 19845 & 19849 & 19850 & 19845 & 19849 & 19850 & 19845 & 19849 & 19850 \\
\hline $\mathrm{pH}$ & $5.03-9.04$ & $6.00-8.23$ & $6.10-7.90$ & $11.0-12.1$ & $10.7-11.8$ & $11.3-11.7$ & $6.28-8.81$ & $6.92-7.44$ & $7.15-11.9$ \\
\hline \multicolumn{10}{|c|}{ Single-Contact Tests $^{(\mathrm{a})}$} \\
\hline 1 month & $(17.4)$ & $(14.4)$ & 37.5 & $(0.151)$ & $(0.217)$ & $(2.47)$ & $(9.02)$ & $(8.87)$ & $(7.37)$ \\
\hline 1 month (dup) & $(16.3)$ & $(16.0)$ & 28.8 & 11.4 & $(0.406)$ & $(2.00)$ & 10.7 & $(8.89)$ & 14.4 \\
\hline \multicolumn{10}{|c|}{ Sequential-Contact Tests } \\
\hline Stage 1 (1d) & 23.8 & $(1.57)$ & 16.1 & 14.9 & 13.9 & 14.1 & $(5.53)$ & $(5.91)$ & 12.1 \\
\hline Stage 1 (dup) & $(4.17)$ & $(1.18)$ & 24.3 & 14.0 & 13.5 & 14.6 & $(2.82)$ & $(4.80)$ & $(9.89)$ \\
\hline Stage 2 (1d) & $(0.371)$ & $(0.119)$ & $<0.500$ & 11.9 & 14.0 & 13.7 & $(0.549)$ & $(0.474)$ & $(7.09)$ \\
\hline Stage 2 (dup) & $(0.483)$ & $(0.144)$ & 0.909 & 14.5 & 13.5 & 13.9 & $(0.468)$ & $(0.414)$ & $(3.54)$ \\
\hline Stage $3(3 d)$ & $(0.462)$ & $(0.303)$ & $<0.500$ & 10.9 & 10.9 & 14.3 & $(0.607)$ & $(0.479)$ & $(6.67)$ \\
\hline Stage 3 (dup) & $(0.208)$ & $(0.460)$ & $<0.500$ & 11.7 & 8.35 & 12.3 & $(0.704)$ & $(0.497)$ & $(1.69)$ \\
\hline Stage 4 (1d) & $(0.200)$ & $<0.500$ & $<0.500$ & 16.0 & 14.9 & 16.4 & $(0.320)$ & $(0.348)$ & $(1.25))$ \\
\hline Stage 4 (dup) & $(0.146)$ & $<0.500$ & $<0.500$ & 16.4 & 15.8 & 14.8 & $(0.342)$ & $(0.186)$ & $(0.657$ \\
\hline Stage 5 (1d) & $(0.021)$ & $<0.500$ & $<0.500$ & 16.9 & 16.9 & 18.4 & $(0.212)$ & $(0.232)$ & $(0.747)$ \\
\hline Stage 5 (dup) & $(0.120)$ & $<0.500$ & $<0.500$ & 17.2 & 16.9 & 18.2 & $(0.279)$ & $(0.238)$ & $(0.571)$ \\
\hline Stage 6 (30d) & 0.895 & 14.3 & 1.12 & 2.28 & $(1.70)$ & $(3.47)$ & $(1.56)$ & $(1.50)$ & $(4.53)$ \\
\hline Stage 6 (dup) & 1.86 & 0.576 & 1.45 & 0.152 & $(0.526)$ & $(1.10)$ & $(1.56)$ & $(1.21)$ & $(3.55)$ \\
\hline
\end{tabular}

\subsubsection{Nitrate}

Nitrate was measured at a total concentration of (250) $\mu \mathrm{g} / \mathrm{g}$-dry wt in tank C-103 residual waste (see Table 2.2 in Cantrell et al. [2007a]). This is below the quantitation limit. No crystalline nitrate mineral 
phases were detected by XRD analysis. SEM/EDS analysis did not detect the presence of nitrogen in any particles of the unleached or leached $\mathrm{C}-103$ residual waste.

Nitrate concentrations measured in the $\mathrm{C}-103$ extracts are shown in Table 4.4. Concentrations as high as $4,890 \mu \mathrm{g} / \mathrm{L}$ were measured (sample $19850 \mathrm{Ca}(\mathrm{OH})_{2}$ extract, 1-month single-contact). The highest extract concentrations were measured in the 1-month single-contacts for all three extract solutions. The $\mathrm{Ca}(\mathrm{OH})_{2}$ 1-month single-contact extracts contained significantly higher nitrate concentrations (approximately double) than those of the DDI water and $\mathrm{CaCO}_{3}$ extracts. The nitrate concentrations in the sequential-contact tests were significantly lower than those of the 1-month single-contact. A significant kinetic rebound effect is observed in Stage 6 for all three extracts but most notably for the $\mathrm{Ca}(\mathrm{OH})_{2}$ and the DDI water extracts.

Table 4.4. C-103 Leach Test Results for Nitrate (concentration units are $\mu \mathrm{g} / \mathrm{L}$ ) (from Cantrell et al. 2007a)

\begin{tabular}{|l|c|c|c|c|c|c|c|c|c|c|c||}
\hline \multirow{2}{*}{ Sample ID } & \multicolumn{9}{|c|}{ DDI Water } & \multicolumn{3}{c||}{$\mathrm{Ca}(\mathrm{OH})_{2}$} & \multicolumn{3}{c||}{$\mathrm{CO}_{3}$} \\
\cline { 2 - 12 } & 19845 & 19849 & 19850 & 19845 & 19849 & 19850 & 19845 & 19849 & 19850 \\
\hline \hline $\mathrm{pH}$ & $5.03-9.04$ & $6.00-8.23$ & $6.10-7.90$ & $11.0-12.1$ & $10.7-11.8$ & $11.3-11.7$ & $6.28-8.81$ & $6.92-7.44$ & $7.15-11.9$ \\
\hline \multicolumn{7}{|c|}{ Single-Contact Tests ${ }^{(a)}$} \\
\hline 1 month & 1,710 & 2,090 & 1,430 & 4,320 & 3,560 & 4,890 & 1,430 & 1,470 & 1,490 \\
\hline 1 month (dup) & 1,650 & 1,830 & 1,910 & 1,450 & 3,710 & 3,920 & 1,640 & 1,250 & 1,080 \\
\hline \multicolumn{7}{|c|}{ Sequential-Contact Tests } \\
\hline Stage 1 (1d) & 346 & 317 & 228 & 597 & 481 & 406 & 597 & 568 & 638 \\
\hline Stage 1 (dup) & 282 & 321 & 247 & 748 & 681 & 480 & 600 & 632 & 544 \\
\hline Stage 2 (1d) & 282 & 255 & 213 & 359 & 258 & 288 & 377 & 343 & 391 \\
\hline Stage 2 (dup) & 431 & 266 & 266 & 365 & 329 & 333 & 383 & 359 & 424 \\
\hline Stage 3 (3d) & 629 & 737 & 587 & 1,010 & 643 & 749 & 525 & 514 & 426 \\
\hline Stage 3 (dup) & 489 & 422 & 568 & 1,230 & 900 & 851 & 506 & 515 & 495 \\
\hline Stage 4 (1d) & 101 & 240 & 170 & 191 & 130 & 226 & 337 & 332 & 284 \\
\hline Stage 4 (dup) & 125 & 139 & 183 & 234 & 169 & 298 & 442 & 351 & 339 \\
\hline Stage 5 (1d) & 97.7 & $<100$ & 123 & 181 & 122 & 175 & 319 & 354 & 287 \\
\hline Stage 5 (dup) & 83.4 & 168 & 146 & 120 & 170 & 211 & 300 & 351 & 326 \\
\hline Stage 6 (30d) & 1,300 & 2,110 & 1,480 & 2,040 & 1,550 & 2,010 & 913 & 779 & 741 \\
\hline Stage 6 (dup) & 1,300 & $<100$ & 1,460 & 2,430 & 1,860 & 2,400 & 844 & 951 & 787 \\
\hline (a) 1-day Single-Contact Test results are shown in the Stage 1 Sequential-Contact results. & & \\
\hline
\end{tabular}

\subsubsection{Percentage Leachable Contaminants of Interest}

Percentages of the most important contaminants of interest (technetium-99 and uranium-238) released during the 1-month single-contact and sequential-contact leaching tests from tank C-103 residual waste relative to acid digestion results are shown in Table 4.5. The percentages of technetium-99 and uranium238 that were leachable were quite low or below the EQL for all leach tests. For all leachants, significant percentages of technetium-99 and uranium-238 were leached only from the 1-month single-contact tests and Stage 1 of the sequential-contact tests. 


\subsection{Contaminants of Interest in C-106 Residual Waste}

Although particles containing uranium were identified by synchrotron-based x-ray techniques, no phases containing the COIs (iodine, technetium, or uranium) were detected by bulk XRD or SEM/EDS analyses of the C-106 residual waste samples. As indicated previously in Section 2.2.3, some of the phases may be amorphous or present at concentrations too low for detection by bulk sample XRD analysis.

Table 4.5. Percentages of Technetium-99 and Uranium-238 Released During Leaching Tests from Tank C-103 Residual Waste Relative to Acid Digestion Results (from Cantrell et al. 2007a)

\begin{tabular}{|c|c|c|}
\hline \multirow[b]{2}{*}{ Leachate } & Technetium-99 & Uranium-238 \\
\hline & \multicolumn{2}{|c|}{ (\% Leachable) } \\
\hline \multicolumn{3}{|c|}{ 1-Month Single-Contact } \\
\hline C-103 Water Leach Range & 4.6 to 9.8 & 5.8 to 6.4 \\
\hline $\mathrm{C}-103 \mathrm{Ca}(\mathrm{OH})_{2}$ Range & 4.4 to 5.8 & 0.0002 to 0.0008 \\
\hline C-103 $\mathrm{CaCO}_{3}$ Range & 4.1 to 7.0 & 4.8 to 8.1 \\
\hline \multicolumn{3}{|c|}{ Stage 1} \\
\hline C-103 Water Leach & 3.7 to 7.1 & 0.5 to 4.9 \\
\hline $\mathrm{C}-103 \mathrm{Ca}(\mathrm{OH})_{2}$ & (3.2) to 6.7 & $(0.001)$ to $(0.004)$ \\
\hline $\mathrm{C}-103 \mathrm{CaCO}_{3}$ & $(4.3)$ to $(5.6)$ & 4.4 to 5.8 \\
\hline \multicolumn{3}{|c|}{ Stage 2} \\
\hline C-103 Water Leach & BDL & 0.1 to 0.3 \\
\hline $\mathrm{C}-103 \mathrm{Ca}(\mathrm{OH})_{2}$ & BDL & $(0.0002)$ to $(0.0004)$ \\
\hline $\mathrm{C}-103 \mathrm{CaCO}_{3}$ & $\mathrm{BDL}$ & 1.2 to 1.6 \\
\hline \multicolumn{3}{|c|}{ Stage 3} \\
\hline C-103 Water Leach & BDL & 0.2 to 0.3 \\
\hline $\mathrm{C}-103 \mathrm{Ca}(\mathrm{OH})_{2}$ & BDL & $(0.0002)$ to $(0.0003)$ \\
\hline $\mathrm{C}-103 \mathrm{CaCO}_{3}$ & $\mathrm{BDL}$ & 1.1 to 1.4 \\
\hline \multicolumn{3}{|c|}{ Stage 4} \\
\hline C-103 Water Leach & BDL & 0.2 to 0.3 \\
\hline $\mathrm{C}-103 \mathrm{Ca}(\mathrm{OH})_{2}$ & BDL & $(0.0002)$ to $(0.0007)$ \\
\hline $\mathrm{C}-103 \mathrm{CaCO}_{3}$ & $\mathrm{BDL}$ & 1.9 to 2.1 \\
\hline \multicolumn{3}{|c|}{ Stage 5} \\
\hline C-103 Water Leach & BDL & 0.2 to 0.3 \\
\hline $\mathrm{C}-103 \mathrm{Ca}(\mathrm{OH})_{2}$ & $\mathrm{BDL}$ & $(0.000004)$ to $(0.0001)$ \\
\hline $\mathrm{C}-103 \mathrm{CaCO}_{3}$ & BDL & 0.9 to 1.6 \\
\hline \multicolumn{3}{|c|}{ Stage 6} \\
\hline C-103 Water Leach & $(0.1)$ to $(0.8)$ & 1.3 to 2.2 \\
\hline $\mathrm{C}-103 \mathrm{Ca}(\mathrm{OH})_{2}$ & $(2.4)$ to $(4.0)$ & $(0.0004)$ to $(0.0008)$ \\
\hline $\mathrm{C}-103 \mathrm{CaCO}_{3}$ & BDL & 2.1 to 2.3 \\
\hline \multicolumn{3}{|c|}{$\begin{array}{l}\text { Values in parentheses are less than the EQL. } \\
\mathrm{BDL}=\text { Below detection limit. } \\
\mathrm{EQL}=\text { Estimated quantitation limit. }\end{array}$} \\
\hline
\end{tabular}

\subsubsection{Uranium}

Uranium has been measured at a total concentration of $247 \mu \mathrm{g} / \mathrm{g}$-dry wt in tank C-106 residual waste (Table 2.4; Deutsch et al. 2007a). No uranium mineral phases were detected by XRD analysis, which was 
expected, given the low uranium concentration. (Under the best sample conditions, XRD requires a mineral concentration of at least $10,000 \mu \mathrm{g} / \mathrm{g}$ to be detectable.) SEM/EDS analysis was also unsuccessful at identifying solid phases containing uranium. Because of this lack of identification of uranium solid phases, the focus of this discussion of uranium in tank C-106 residual waste is its leachability from the waste.

Table 4.6 lists the dissolved concentrations of uranium present for each of the leach tests discussed in detail in Deutsch et al. (2006, 2007a). The amounts of uranium leached in terms of percentages are discussed in Section 4.3.6. The highest uranium concentrations were found in the 1-month single-contact extractions for all three extractants. The highest extractable uranium concentrations occurred in the $\mathrm{CaCO}_{3}$ extracts 1-month single-contact (sample 405) with a concentration of $76 \mu \mathrm{g} / \mathrm{L}$ uranium. The formation of dissolved uranium carbonate complexes discussed in Section 3.4.2 is the likely reason for

Table 4.6. C-106 Residual Waste Leach Test Results for Uranium (concentration units are $\mu \mathrm{g} / \mathrm{L}$ ) (from Deutsch et al. 2006, 2007a)

\begin{tabular}{|c|c|c|c|c|c|c|}
\hline \multirow[b]{2}{*}{ Sample Number } & \multicolumn{2}{|c|}{ DDI Water } & \multicolumn{2}{|c|}{$\mathrm{C} \mathrm{Ca}(\mathrm{OH})_{2}$} & \multicolumn{2}{|c|}{$\mathrm{CaCO}_{3}{ }^{(\mathrm{a})}$} \\
\hline & 404 & 405 & 404 & 405 & 404 & 405 \\
\hline $\mathrm{pH}$ & $6.7-7.6$ & $6.7-7.7$ & $12.0-12.6$ & $11.4-12.5$ & $11.4-11.8$ & $11.3-11.8$ \\
\hline \multicolumn{7}{|c|}{ Single-Contact Tests ${ }^{(b)}$} \\
\hline 2 week & 32.92 & 18.66 & & & & \\
\hline 2 week (dup) & 23.74 & 23.76 & & & & \\
\hline 1 month & 27.02 & 17.69 & 41.96 & 25.52 & 52.05 & 64.0 \\
\hline 1 month (dup) & 20.64 & 21.48 & 21.54 & 44.69 & 46.84 & 76.36 \\
\hline 1 month (triplicate) & & & 36.72 & 74.73 & & \\
\hline \multicolumn{7}{|c|}{ Sequential-Contact Tests } \\
\hline Stage $1(1 \mathrm{~d})$ & 54.07 & 33.36 & $(0.245)$ & 7.43 & 0.67 & 0.97 \\
\hline Stage 1 (dup) & 57.0 & 40.64 & $(0.480)$ & $(0.020)$ & $(0.470)$ & 0.90 \\
\hline Stage 1 (triplicate) & & & $(0.090)$ & $(0.020)$ & & \\
\hline Stage 2 (1d) & 10.58 & 7.54 & 1.66 & $(0.040)$ & 0.75 & 0.98 \\
\hline Stage 2 (dup) & 10.18 & 8.66 & 1.19 & 1.81 & 0.85 & 0.57 \\
\hline Stage 2 (triplicate) & & & 1.87 & $(0.150)$ & & \\
\hline Stage $3(4 d)$ & 4.50 & 3.10 & 1.16 & 1.18 & 1.01 & 1.01 \\
\hline Stage 3 (dup) & 4.30 & 3.29 & 1.56 & 1.37 & $(0.490)$ & 1.04 \\
\hline Stage 3 (triplicate) & & & 1.62 & 1.35 & & \\
\hline Stage 4 (1d) & 2.19 & 0.81 & 1.03 & $(0.150)$ & 0.93 & 1.21 \\
\hline Stage 4 (dup) & 1.44 & 1.02 & 0.96 & 1.57 & 0.94 & 1.14 \\
\hline Stage 4 (triplicate) & & & 1.40 & $(0.480)$ & & \\
\hline Stage 5 (1d) & 0.82 & 0.36 & 0.73 & 1.14 & $(0.440)$ & 1.24 \\
\hline Stage 5 (dup) & 0.65 & 0.45 & 1.21 & 1.55 & 0.86 & 1.17 \\
\hline Stage 5 (triplicate) & & & 1.73 & 1.22 & & \\
\hline Stage 6 A (43d) & 1.56 & 1.25 & & & & \\
\hline Stage 6 B (82d) & 1.35 & 1.24 & & & & \\
\hline Stage $6(43 d)$ & & & 0.81 & 0.69 & 0.89 & 1.19 \\
\hline Stage 6 (dup) & & & 0.74 & 0.74 & 0.96 & 1.04 \\
\hline Stage 6 (triplicate) & & & $(0.32)$ & 0.58 & & \\
\hline \multicolumn{7}{|c|}{$\begin{array}{l}\text { Values in parentheses are less than the EQL. } \\
\text { (a) } \mathrm{CaCO}_{3} \text { leaches were done on material that had previously been leached with } \mathrm{Ca}(\mathrm{OH})_{2} \text {. } \\
\text { (b) 1-day single-contact test results are shown in the Stage } 1 \text { sequential-contact results. } \\
\text { EQL = Estimated quantitation limit. }\end{array}$} \\
\hline
\end{tabular}


the high dissolved uranium concentrations in the $\mathrm{CaCO}_{3}$ single-contact leach tests. For the DDI water extracts, the 1-day and 2-week single-contact extracts also had relatively high concentrations (19 to $54 \mu \mathrm{g} / \mathrm{L})$. The uranium concentrations measured in Stages 2 through 5 of the DDI water extracts decreased sequentially to less than $1 \mu \mathrm{g} / \mathrm{L}$, with a small rebound effect occurring in Stage 6 (43-day extraction). Uranium concentrations in Stages 2 through 6 for the $\mathrm{Ca}(\mathrm{OH})_{2}$ and $\mathrm{CaCO}_{3}$ extractions were all less than $2 \mu \mathrm{g} / \mathrm{L}$.

\subsubsection{Technetium-99}

Technetium-99 was measured at a total concentration of $1.16 \mu \mathrm{g} / \mathrm{g}$-dry wt (from fusion method) in tank C-106 residual waste (Table 2.4; Deutsch et al. 2007a). This concentration is too low to allow for detecting crystalline technetium mineral phases by XRD analysis. Technetium was also not detectable in any of the particles analyzed by SEM/EDS. Because of this lack of identification of technetium solid phases, the focus of this discussion of technetium in tank C-106 residual waste is on its leachability from the waste.

Technetium-99 concentrations measured in the C-106 residual waste leachate solutions are shown in Table 4.7. The amounts of technetium-99 leached in terms of percentages are discussed in Section 4.3.6. The concentrations in each of the waste leachate solutions are generally quite low, at less than $2 \mu \mathrm{g} / \mathrm{L}$. The $\mathrm{Ca}(\mathrm{OH})_{2}$ extracts have the highest concentrations (up to $1.5 \mu \mathrm{g} / \mathrm{L}$ ). In the $\mathrm{Ca}(\mathrm{OH})_{2}$ extracts, concentrations above the EQL were measured only in the 1-month single contacts and Stages 1 and 6 . For the DDI water extracts, concentrations above the EQL were measured in the single contacts (2-week and 1-month), Stages 1, 2, 3, 5, and 6. No concentrations above the EQL were measured in the $\mathrm{CaCO}_{3}$ extracts. The occurrence of the highest dissolved technetium-99 in the $\mathrm{Ca}(\mathrm{OH})_{2}$ leachates may be due to the presence of this contaminant in iron hydroxide solids, which are relatively soluble under the high $\mathrm{pH}$ conditions ( $\mathrm{pH} 11.4$ to 12.6) in these leaching solutions. Alternatively, if the technetium-99 were incorporated within aluminum oxyhydroxides, it could be released as they dissolve (aluminum oxyhydroxides are even more soluble than iron hydroxides at high $\mathrm{pH}$ ). As indicated earlier, selective extraction tests conducted on C-204 waste (Deutsch et al. 2007b) do not support this alternative. Note that the $\mathrm{CaCO}_{3}$ leaches were conducted on residual waste samples that had previously been leached with the $\mathrm{Ca}(\mathrm{OH})_{2}$ leachant because residual waste that is covered with cementitious material to fill the tank may undergo leaching by a $\mathrm{Ca}(\mathrm{OH})_{2}$ saturated solution prior to being leached by a $\mathrm{CaCO}_{3}$-saturated solution.

\subsubsection{Iodine-129}

Iodine-129 was measured at a total concentration of $0.67 \mu \mathrm{g} / \mathrm{g}$-dry wt in tank C-106 residual waste (Table 2.4; Deutsch et al. 2007a). This concentration is too low to allow for detecting crystalline iodine mineral phases by XRD analysis. Iodine was also not detected in any of the particles analyzed by $\mathrm{SEM} / \mathrm{EDS}$. Because of this lack of identification of iodine solid phases, the focus of this discussion of iodine-129 in tank C-106 residual waste is on its leachability from the waste.

Iodine-129 concentrations in the C-106 residual waste leachate solutions are shown in Table 4.8. The concentrations in all the leachate solutions are low $(<1.0 \mu \mathrm{g} / \mathrm{L})$, with all measured concentrations below the EQL or the detection limit. There is no apparent difference in leachability for the three leaching solutions. 
Table 4.7. C-106 Leach Test Results for Technetium (concentration units are $\mu \mathrm{g} / \mathrm{L}$ ) (from Deutsch et al. 2006, 2007a)

\begin{tabular}{|c|c|c|c|c|c|c|}
\hline \multirow[b]{2}{*}{ Sample Number } & \multicolumn{2}{|c|}{ DDI Water } & \multicolumn{2}{|c|}{$\mathrm{Ca}(\mathrm{OH})_{2}$} & \multicolumn{2}{|c|}{$\mathrm{CaCO}_{3}{ }^{(\mathrm{a})}$} \\
\hline & 404 & 405 & 404 & 405 & 404 & 405 \\
\hline $\mathrm{pH}$ & $6.7-7.6$ & $6.7-7.7$ & $12.0-12.6$ & $11.4-12.5$ & $11.4-11.8$ & $11.3-11.8$ \\
\hline \multicolumn{7}{|c|}{ Single-Contact Tests ${ }^{(\mathbf{b})}$} \\
\hline 2 week & 0.290 & 0.173 & & & & \\
\hline 2 week (dup) & 0.230 & 0.195 & & & & \\
\hline 1 month & 0.261 & 0.163 & 1.19 & 1.02 & $(0.340)$ & $(0.260)$ \\
\hline 1 month (dup) & 0.218 & 0.180 & 1.14 & 0.985 & $(0.388)$ & $(0.240)$ \\
\hline 1 month (triplicate) & & & $(1.09)$ & 1.19 & & \\
\hline \multicolumn{7}{|c|}{ Sequential-Contact Tests } \\
\hline Stage $1(1 \mathrm{~d})$ & 0.167 & 0.0870 & $(0.415)$ & 0.873 & $(0.055)$ & $(0.0900)$ \\
\hline Stage 1 (dup) & 0.147 & 0.0660 & 0.653 & 0.618 & $(0.040)$ & $(0.0700)$ \\
\hline Stage 1 (triplicate) & & & $(0.370)$ & $(0.290)$ & & \\
\hline Stage $2(1 \mathrm{~d})$ & 0.00900 & 0.00600 & $(0.190)$ & 0.400 & $(0.050)$ & $(0.0200)$ \\
\hline Stage 2 (dup) & 0.0270 & 0.0300 & $(0.170)$ & $(0.150)$ & $(0.060)$ & $(0.0200)$ \\
\hline Stage 2 (triplicate) & & & $(0.100)$ & $(0.240)$ & & \\
\hline Stage $3(4 d)$ & $(0.0390)$ & $(0.0240)$ & $(0.080)$ & $(0.120)$ & $(0.040)$ & $(0.0100)$ \\
\hline Stage 3 (dup) & 0.0180 & 0.0270 & $(0.100)$ & $(0.110)$ & $(0.030)$ & $(0.0300)$ \\
\hline Stage 3 (triplicate) & & & $(0.070)$ & $(0.110)$ & & \\
\hline Stage 4 (1d) & $(0.00900)$ & $(0.0300)$ & $(0.195)$ & $(0.260)$ & $(0.070)$ & $(0.0500)$ \\
\hline Stage 4 (dup) & $(0.0300)$ & $(0.00900)$ & $(0.250)$ & $(0.210)$ & $(0.050)$ & $(0.0400)$ \\
\hline Stage 4 (triplicate) & & & $(0.150)$ & $(0.310)$ & & \\
\hline Stage 5 (1d) & $(0.0300)$ & $(0.0300)$ & $(0.120)$ & $(0.190)$ & $(0.050)$ & $(0.0400)$ \\
\hline Stage 5 (dup) & $(0.0300)$ & 0.0300 & $(0.160)$ & $(0.110)$ & $(0.050)$ & $(0.0400)$ \\
\hline Stage 5 (triplicate) & & & $(0.100)$ & $(0.180)$ & & \\
\hline Stage 6 A (43d) & 0.277 & 0.185 & & & & \\
\hline Stage 6 B (82d) & 0.308 & 0.210 & & & & \\
\hline Stage $6(43 d)$ & & & 1.20 & 1.50 & $(0.305)$ & $(0.320)$ \\
\hline Stage 6 (dup) & & & 1.36 & 1.14 & $(0.260)$ & $(0.190)$ \\
\hline Stage 6 (triplicate) & & & 0.585 & 1.15 & & \\
\hline \multicolumn{7}{|c|}{$\begin{array}{l}\text { Values in parentheses are less than the EQL. } \\
\text { (a) } \mathrm{CaCO}_{3} \text { leaches were done on material that had previously been leached with } \mathrm{Ca}(\mathrm{OH})_{2} \text {. } \\
\text { (b) 1-day single-contact test results are shown in the Stage } 1 \text { sequential-contact results. } \\
\text { EQL = Estimated quantitation limit. }\end{array}$} \\
\hline
\end{tabular}

\subsubsection{Chromium}

Total chromium measured in tank C-106 residual waste was below the EQL at (896) $\mu \mathrm{g} / \mathrm{g}$-dry wt (Table 2.4; Deutsch et al. 2007a). No crystalline chromium mineral phases were detected by XRD analysis. SEM/EDS analysis indicated that chromium was generally associated with iron solids, likely oxides or hydroxides. The release of chromium from this waste is likely tied to the dissolution of iron oxide(s) containing trace amounts of coprecipitated chromium. 
Table 4.8. C-106 Leach Test Results for Iodine-129 (concentration units are $\mu \mathrm{g} / \mathrm{L}$ ) (from Deutsch et al. 2006, 2007a)

\begin{tabular}{|c|c|c|c|c|c|c|}
\hline \multirow[b]{2}{*}{ Sample Number } & \multicolumn{2}{|c|}{ DDI Water } & \multicolumn{2}{|c|}{$\overline{\mathrm{Ca}(\mathrm{OH})_{2}}$} & \multicolumn{2}{|c|}{$\mathrm{CaCO}_{3}{ }^{(\mathrm{a})}$} \\
\hline & 404 & 405 & 404 & 405 & 404 & 405 \\
\hline $\mathrm{pH}$ & $6.7-7.6$ & $6.7-7.7$ & $12.0-12.6$ & $11.4-12.5$ & $11.4-11.8$ & $11.3-11.8$ \\
\hline \multicolumn{7}{|c|}{ Single-Contact Tests ${ }^{(\mathbf{b})}$} \\
\hline 2 week & $<0.250$ & $(0.250)$ & & & & \\
\hline 2 week (dup) & $(0.00700)$ & $(0.0580)$ & & & & \\
\hline 1 month & $(0.00500)$ & $<0.250$ & $<1.00$ & $(0.0061)$ & & \\
\hline 1 month (dup) & $(0.0520)$ & $(0.0420)$ & $(0.0707)$ & $(0.0535)$ & & \\
\hline 1 month (triplicate) & & & $<1.00$ & $(0.138)$ & & \\
\hline \multicolumn{7}{|c|}{ Sequential-Contact Tests } \\
\hline Stage $1(1 \mathrm{~d})$ & $(0.0350)$ & $(0.0120)$ & $(0.0466)$ & $(0.163)$ & $(0.0874)$ & $(0.139)$ \\
\hline Stage 1 (dup) & $(0.00500)$ & $<0.250$ & $(0.0951)$ & $(0.136)$ & $(0.0651)$ & $(0.0896)$ \\
\hline Stage 1 (triplicate) & & & $<1.00$ & $(0.148)$ & & \\
\hline Stage $2(1 \mathrm{~d})$ & & & $(0.0164)$ & $(0.0214)$ & $(0.0731)$ & $(0.295)$ \\
\hline Stage 2 (dup) & & & $(0.0432)$ & $(0.105)$ & $<1.00$ & $(0.272)$ \\
\hline Stage 2 (triplicate) & & & $(0.0366)$ & $(1.00)$ & & \\
\hline Stage $3(4 d)$ & & & $<1.00$ & $(1.00)$ & $(0.0122)$ & $(0.203)$ \\
\hline Stage 3 (dup) & & & $<1.00$ & $(1.00)$ & $(0.126)$ & $(0.345)$ \\
\hline Stage 3 (triplicate) & & & $(0.0696)$ & $(0.0207)$ & & \\
\hline Stage 4 (1d) & & & $<1.00$ & $(0.0258)$ & $(0.0581)$ & $(0.253)$ \\
\hline Stage 4 (dup) & & & $(0.0405)$ & $(1.00)$ & $(0.201)$ & $(0.174)$ \\
\hline Stage 4 (triplicate) & & & $(0.168)$ & $(1.00)$ & & \\
\hline Stage 5 (1d) & & & $(0.123)$ & $(0.128)$ & $(0.104)$ & $(0.200)$ \\
\hline Stage 5 (dup) & & & $<1.00$ & $(0.0852)$ & $(0.169)$ & $(0.220)$ \\
\hline Stage 5 (triplicate) & & & $(0.0846)$ & $(0.0898)$ & & \\
\hline Stage 6 A (43d) & $(0.0300)$ & $(0.0650)$ & & & & \\
\hline \multicolumn{7}{|l|}{ Stage 6 B (82d) } \\
\hline Stage $6(43 d)$ & & & $(0.130)$ & $(0.0066)$ & $(0.190)$ & $(0.120)$ \\
\hline Stage 6 (dup) & & & $(0.00692)$ & $(0.121)$ & $(0.0379)$ & $(0.127)$ \\
\hline Stage 6 (triplicate) & & & $(0.00751)$ & $(0.0685)$ & & \\
\hline \multicolumn{7}{|c|}{$\begin{array}{l}\text { Values in parentheses are less than the EQL. } \\
\text { (a) } \mathrm{CaCO}_{3} \text { leaches were done on material that had previously been leached with } \mathrm{Ca}(\mathrm{OH})_{2} \text {. } \\
\text { (b) 1-day single-contact test results are shown in the Stage } 1 \text { sequential-contact results. } \\
\mathrm{EQL}=\text { Estimated quantitation limit. }\end{array}$} \\
\hline
\end{tabular}

Chromium concentrations measured in the C-106 extracts are shown in Table 4.9. Concentrations above the EQL were measured only in the 1-month single-contact of DDI water leaches, at about $20 \mu \mathrm{g} / \mathrm{L}$. The higher EQLs for the $\mathrm{Ca}(\mathrm{OH})_{2}$ and $\mathrm{CaCO}_{3}$ leaches did not allow for confirmed measurements in these solutions. If the qualified values for these two solutions are correct, the higher concentrations suggest greater leachability of chromium under higher $\mathrm{pH}$ conditions. The greater leachability of chromium in the $\mathrm{Ca}(\mathrm{OH})_{2}$ and $\mathrm{CaCO}_{3}$ leachants may be due to the higher solubility of the iron oxide compounds under these high $\mathrm{pH}$ conditions or the propensity to convert from $\mathrm{Cr}^{3+}$ hydroxide to chromate under such conditions (see Figure 3.10, upper right-hand side of the stability field). 
Table 4.9. C-106 Leach Test Results for Chromium (ICP-OES) (concentration units are $\mu \mathrm{g} / \mathrm{L}$ ) (from Deutsch et al. 2007a)

\begin{tabular}{|c|c|c|c|c|c|c|}
\hline \multirow[b]{2}{*}{ Sample Number } & \multicolumn{2}{|c|}{ DDI Water } & \multicolumn{2}{|c|}{$\overline{\mathrm{Ca}(\mathrm{OH})_{2}}$} & \multicolumn{2}{|c|}{$\mathrm{CaCO}_{3}{ }^{(\mathrm{a})}$} \\
\hline & 404 & 405 & 404 & 405 & 404 & 405 \\
\hline $\mathrm{pH}$ & $6.7-7.6$ & $6.7-7.7$ & $12.0-12.6$ & $11.4-12.5$ & $11.4-11.8$ & $11.3-11.8$ \\
\hline \multicolumn{7}{|c|}{ Single-Contact Tests ${ }^{(\mathbf{b})}$} \\
\hline 2 week & $(23.3)$ & $(23.0)$ & & & & \\
\hline 2 week (dup) & $(20.8)$ & $(23.0)$ & & & & \\
\hline 1 month & 19.5 & 18.6 & $(367)$ & $(367)$ & $(260)$ & (209) \\
\hline 1 month (dup) & 18.5 & 20.9 & $(548)$ & $(524)$ & $(306)$ & (299) \\
\hline 1 month (triplicate) & & & $(602)$ & $(355)$ & & \\
\hline \multicolumn{7}{|c|}{ Sequential-Contact Tests } \\
\hline Stage 1 (1d) & $(23.4)$ & $(19.1)$ & $(169)$ & $(198)$ & $(179)$ & $(320)$ \\
\hline Stage 1 (dup) & $(8.12)$ & $<313$ & $(60.8)$ & $(210)$ & (96.6) & $(106)$ \\
\hline Stage 1 (triplicate) & & & $(147)$ & $(126)$ & & \\
\hline Stage $2(1 \mathrm{~d})$ & $<313$ & $<313$ & $(177)$ & $(213)$ & $(227)$ & $(228)$ \\
\hline Stage 2 (dup) & $<313$ & $(7.26)$ & $(238)$ & $(83.5)$ & $(121)$ & $(167)$ \\
\hline Stage 2 (triplicate) & & & $(217)$ & $(116)$ & & \\
\hline Stage $3(4 d)$ & $(9.07)$ & $<313$ & $(143)$ & $(37.0)$ & $(173)$ & $(220)$ \\
\hline Stage 3 (dup) & $<313$ & $<313$ & (219) & $(127)$ & $(63.8)$ & $(95.5)$ \\
\hline Stage 3 (triplicate) & & & $(50)$ & $(136)$ & & \\
\hline Stage 4 (1d) & $<313$ & $<313$ & $(204)$ & $(296)$ & $(74.3)$ & $(167)$ \\
\hline Stage 4 (dup) & $<313$ & $<313$ & $(227)$ & $(298)$ & $(198)$ & $(237)$ \\
\hline Stage 4 (triplicate) & & & $(208)$ & $(179)$ & & \\
\hline Stage $5(1 \mathrm{~d})$ & $<313$ & $(14.0)$ & $(113)$ & $(184)$ & $(235)$ & $(333)$ \\
\hline Stage 5 (dup) & $(6.95)$ & $(13.9)$ & $(214)$ & $(84.6)$ & $(55.6)$ & $(160)$ \\
\hline Stage 5 (triplicate) & & & $(320)$ & $(182)$ & & \\
\hline Stage 6 A (43d) & $(6.72)$ & $(5.67)$ & & & & \\
\hline Stage 6 B (82d) & $(9.69)$ & $(7.95)$ & & & & \\
\hline Stage $6(43 d)$ & & & $(215)$ & $(338)$ & $(129)$ & $(156)$ \\
\hline Stage 6 (dup) & & & $(245)$ & $(254)$ & $(114)$ & $(126)$ \\
\hline Stage 6 (triplicate) & & & $(167)$ & $(233)$ & & \\
\hline \multicolumn{7}{|c|}{$\begin{array}{l}\text { Values in parentheses are less than the EQL. } \\
\text { (a) } \mathrm{CaCO}_{3} \text { leaches were done on material that had previously been leached with } \mathrm{Ca}(\mathrm{OH})_{2} \text {. } \\
\text { (b) 1-day single-contact test results are shown in the Stage } 1 \text { sequential-contact results. } \\
\mathrm{EQL}=\text { Estimated quantitation limit. }\end{array}$} \\
\hline
\end{tabular}

Three different series of sequential selective extractions were conducted on residual waste from C-106. In a first series, extractions were designed to first remove soluble salts, then manganese oxyhydroxides, then aluminum oxyhydroxides, and finally any remaining iron and aluminum oxyhydroxides (see Deutsch et al. 2007a for details on the selective extraction methods). The selective extraction tests indicated a fairly strong correlation of chromium with iron. This was also observed in the SEM/EDS analyses. 


\subsubsection{Nitrate}

Nitrate was not measured above its detection limit of $70 \mu \mathrm{g} / \mathrm{g}$-dry wt in tank C-106 residual waste (Table 2.4; Deutsch et al. 2007a). No crystalline nitrate mineral phases were detected by XRD analysis. SEM/EDS analysis did not indicate the presence of any phases containing nitrogen. Nitrate concentrations measured in the $\mathrm{C}-106$ leachates are shown in Table 4.10. Detectable concentrations were measured only in Stage 6 of the DDI water extracts at concentrations of approximately 1,100 $\mu \mathrm{g} / \mathrm{L}$.

Table 4.10. C-106 Leach Test Results for Nitrate (concentration units are $\mu \mathrm{g} / \mathrm{L}$ ) (from Deutsch et al. 2007a)

\begin{tabular}{|c|c|c|c|c|c|c|}
\hline \multirow[b]{2}{*}{ Sample Number } & \multicolumn{2}{|c|}{ DDI Water } & \multicolumn{2}{|c|}{$\overline{\mathrm{Ca}(\mathrm{OH})_{2}}$} & \multicolumn{2}{|c|}{$\mathrm{CaCO}_{3}{ }^{\text {(a) }}$} \\
\hline & 404 & 405 & 404 & 405 & 404 & 405 \\
\hline $\mathrm{pH}$ & $6.7-7.6$ & $6.7-7.7$ & $12.0-12.6$ & $11.4-12.5$ & $11.4-11.8$ & $11.3-11.8$ \\
\hline \multicolumn{7}{|c|}{ Single-Contact Tests ${ }^{(\mathbf{b})}$} \\
\hline \multicolumn{7}{|l|}{2 week } \\
\hline \multicolumn{7}{|l|}{2 week (dup) } \\
\hline 1 month & $<3,600$ & $<4,320$ & $<4,330$ & $<4,330$ & $<4,330$ & $<4,330$ \\
\hline 1 month (dup) & $<3,600$ & $<4,320$ & $<4,330$ & $<4,330$ & $<4,330$ & $<4,330$ \\
\hline 1 month (triplicate) & & & $<4,330$ & $<4,330$ & $<4,330$ & $<4,330$ \\
\hline \multicolumn{7}{|c|}{ Sequential-Contact Tests } \\
\hline Stage $1(1 d)$ & $<433$ & $<433$ & $<4,330$ & $<4,330$ & $<4,330$ & $<4,330$ \\
\hline Stage 1 (dup) & $<433$ & $<433$ & $<4,330$ & $<4,330$ & $<4,330$ & $<4,330$ \\
\hline Stage 1 (triplicate) & & & $<4,330$ & $<4,330$ & $<4,330$ & $<4,330$ \\
\hline Stage $2(1 \mathrm{~d})$ & $<433$ & $<433$ & $<4,330$ & $<4,330$ & $<4,330$ & $<4,330$ \\
\hline Stage 2 (dup) & $<433$ & $<433$ & $<4,330$ & $<4,330$ & $<4,330$ & $<4,330$ \\
\hline Stage 2 (triplicate) & & & $<4,330$ & $<4,330$ & $<4,330$ & $<4,330$ \\
\hline Stage $3(4 d)$ & $<433$ & $<433$ & $<4,330$ & $<4,330$ & $<4,330$ & $<4,330$ \\
\hline Stage 3 (dup) & $<433$ & $<433$ & $<4,330$ & $<4,330$ & $<4,330$ & $<4,330$ \\
\hline Stage 3 (triplicate) & & & $<4,330$ & $<4,330$ & $<4,330$ & $<4,330$ \\
\hline Stage 4 (1d) & $<433$ & $<433$ & $<4,330$ & $<4,330$ & $<4,330$ & $<4,330$ \\
\hline Stage 4 (dup) & $<433$ & $<433$ & $<4,330$ & $<4,330$ & $<4,330$ & $<4,330$ \\
\hline Stage 4 (triplicate) & & & $<4,330$ & $<4,330$ & $<4,330$ & $<4,330$ \\
\hline Stage $5(1 \mathrm{~d})$ & $<433$ & $<433$ & $<4,330$ & $<4,330$ & $<4,330$ & $<4,330$ \\
\hline Stage 5 (dup) & $<433$ & $<433$ & $<4,330$ & $<4,330$ & $<4,330$ & $<4,330$ \\
\hline Stage 5 (triplicate) & & & $<4,330$ & $<4,330$ & $<4,330$ & $<4,330$ \\
\hline Stage 6 A (43d) & 1,090 & 1,150 & & & & \\
\hline Stage 6 B (82d) & 1,090 & 1,020 & & & & \\
\hline Stage 6 (43d) & & & $<4,330$ & $<4,330$ & $<4,330$ & $<4,330$ \\
\hline Stage 6 (dup) & & & $<4,330$ & $<4,330$ & $<4,330$ & $<4,330$ \\
\hline Stage 6 (triplicate) & & & $<4,330$ & $<4,330$ & $<4,330$ & $<4,330$ \\
\hline
\end{tabular}

\subsubsection{Percentage Leachable Contaminants of Interest}

Percentages of the most important contaminants of interest (technetium-99, uranium-238, and iodine-129) released during the 1-month single-contact and sequential-contact leaching tests from tank C-106 residual waste relative to fusion results are shown in Table 4.11. The percentages of technetium-99, 
Table 4.11. Percentages of Technetium-99, Uranium-238, and Iodine-129 Released During Leaching Tests from Tank C-106 Residual Waste Relative to Fusion Results (from Deutsch et al. 2007a)

\begin{tabular}{|c|c|c|c|}
\hline \multirow[b]{2}{*}{ Leachate } & Technetium-99 & Uranium-238 & Iodine-129 \\
\hline & \multicolumn{3}{|c|}{$\begin{array}{c}(\% \text { Leachable }) \\
\end{array}$} \\
\hline \multicolumn{4}{|c|}{ 1-Month Single-Contact } \\
\hline C-106 Water Leach Range & 2.4 to 3.2 & 1.3 to 1.4 & $<1.1$ \\
\hline $\mathrm{C}-106 \mathrm{Ca}(\mathrm{OH})_{2}$ Range & 8.6 to 11.8 & 1.8 to 2.9 & $<3.1$ \\
\hline $\mathrm{C}-106 \mathrm{CaCO}_{3}$ Range & $<6.0$ & 2.2 to 3.4 & NA \\
\hline \multicolumn{4}{|c|}{ Stage 1} \\
\hline C-106 Water Leach & 1.3 to 2.0 & 2.8 to 3.4 & $<1.4$ \\
\hline $\mathrm{C}-106 \mathrm{Ca}(\mathrm{OH})_{2}$ & 5.2 to 6.3 & 0.3 & $<3.2$ \\
\hline $\mathrm{C}-106 \mathrm{CaCO}_{3}$ & ND & 0.02 to 0.04 & $<13.6$ \\
\hline \multicolumn{4}{|c|}{ Stage 2} \\
\hline C-106 Water Leach & $<0.58$ & 0.5 to 0.7 & NA \\
\hline $\mathrm{C}-106 \mathrm{Ca}(\mathrm{OH})_{2}$ & $<6.4$ & 0.02 to 0.1 & $<3.2$ \\
\hline $\mathrm{C}-106 \mathrm{CaCO}_{3}$ & ND & 0.03 to 0.04 & $<13.6$ \\
\hline \multicolumn{4}{|c|}{ Stage 3} \\
\hline C-106 Water Leach & $<0.58$ & 0.2 to 0.3 & NA \\
\hline $\mathrm{C}-106 \mathrm{Ca}(\mathrm{OH})_{2}$ & $<6.4$ & 0.06 to 0.09 & $<3.2$ \\
\hline $\mathrm{C}-106 \mathrm{CaCO}_{3}$ & ND & 0.02 to 0.05 & $<13.6$ \\
\hline \multicolumn{4}{|c|}{ Stage 4} \\
\hline C-106 Water Leach & $<0.58$ & 0.08 to 0.11 & NA \\
\hline $\mathrm{C}-106 \mathrm{Ca}(\mathrm{OH})_{2}$ & $<6.4$ & 0.05 to 0.09 & $<3.2$ \\
\hline $\mathrm{C}-106 \mathrm{CaCO}_{3}$ & ND & 0.04 to 0.05 & $<13.6$ \\
\hline \multicolumn{4}{|c|}{ Stage 5} \\
\hline C-106 Water Leach & $<0.58$ & 0.03 to 0.04 & NA \\
\hline $\mathrm{C}-106 \mathrm{Ca}(\mathrm{OH})_{2}$ & $<6.4$ & 0.02 to 0.08 & $<3.2$ \\
\hline $\mathrm{C}-106 \mathrm{CaCO}_{3}$ & ND & 0.02 to 0.05 & $<13.6$ \\
\hline \multicolumn{4}{|c|}{ Stage 6} \\
\hline C-106 Water Leach & $<0.58$ & 0.09 to 0.10 & NA \\
\hline $\mathrm{C}-106 \mathrm{Ca}(\mathrm{OH})_{2}$ & $<6.4$ & 0.02 to 0.04 & $<3.2$ \\
\hline $\mathrm{C}-106 \mathrm{CaCO}_{3}$ & ND & 0.04 to 0.05 & $<13.6$ \\
\hline
\end{tabular}

uranium-238, and iodine-129 that were leachable were quite low or below the EQL for all leach tests. For all leachants, significant percentages of technetium- 99 and uranium-238 were leached only from the 1-month single-contact tests and Stage 1 of the sequential-contact tests. The percentages of iodine-129 leached were below the detection limit.

\subsection{Contaminants of Interest in C-202 Residual Waste}

No phases containing the COIs iodine or technetium were detected by bulk XRD or SEM/EDS analyses of the C-202 residual waste samples. As indicated previously in Section 2.2.3, some of the phases that were not identified by XRD may be amorphous or present at concentrations too low for detection by XRD, which requires crystalline phases to be present at 1 to $5 \mathrm{wt} \%$ of the sample. 


\subsubsection{Uranium}

Uranium has been measured at a total concentration of 236,000 $\mu \mathrm{g} / \mathrm{g}$-dry wt $(23.6 \%)$ in tank C-202 residual waste (Table 2.5; Deutsch et al. 2007c). No crystalline uranium mineral phases were detected by XRD analysis. These results indicate that the bulk of uranium present in C-202 residual waste occurs as amorphous phases. SEM/EDS analysis indicated that a major component of the residual waste was a uranium phase containing the elements $\mathrm{U}-\mathrm{Na}-\mathrm{C}-\mathrm{O}-\mathrm{P} \pm \mathrm{H}$.

Note that the procedure for sequential-contact testing was changed for tank C-202 and all subsequent tank testing compared to the procedure for tank C-106. For C-106, the samples were initially leached with the $\mathrm{Ca}(\mathrm{OH})_{2}$ leachant followed by leaching with the $\mathrm{CaCO}_{3}$-saturated solution. For testing of samples from all subsequent tanks, the sequential leach tests using these two leachants were done on separate samples. The procedure was changed because a final decision has not been made on the tank filling material, and cementitious material may not be used. If cementitious material is not used, the $\mathrm{CaCO}_{3}$ leachant is considered to be most representative of a leachant contacting tank waste because it reflects the composition of vadose zone pore water at the Hanford Site.

Table 4.12 lists the dissolved concentrations of uranium present for each of the leach tests discussed in detail in Deutsch et al. (2007c). The amounts of uranium leached in terms of percentages are discussed in Section 4.4.5. Significant concentrations of uranium were extractable from all three extractants and at all stages. The highest extractable uranium concentrations occurred in the $\mathrm{CaCO}_{3}$ extracts, with concentrations as high as $79,000 \mu \mathrm{g} / \mathrm{L} \mathrm{U}$. Formation of aqueous carbonate complexes significantly increases the solubility of uranium phases and is the likely reason for the occurrence of the most soluble uranium being found in the $\mathrm{CaCO}_{3}$ leachates. The highest concentrations in the $\mathrm{CaCO}_{3}$ extracts were observed in the 1-month single-contact and in Stages 1, 5, and 6 of the sequential leaches. Stages 2 through 4 had uranium concentrations that were significantly less than Stage 1. There is a concentration increase for the longer extraction periods (Stage 3-3 days and Stage 6-30 days). The reason for the high concentrations observed in Stage 5 is not clear. The lower $\mathrm{pH}$ of the $\mathrm{CaCO}_{3}$ leachant compared to $\mathrm{C}-106$ values (Table 4.11) is due to the change in procedure for the sequential-contact tests, as discussed in the previous paragraph.

The DDI water extracts also had fairly high concentrations of extractable uranium, with a maximum concentration of $46,600 \mu \mathrm{g} / \mathrm{L}$ in the Stage 6 extraction. The highest uranium concentrations in the DDI water extracts were observed in the 1-month single-contact and Stages 1 and 6 of the sequential extractions. Stages 2 through 5 had uranium concentrations that were significantly less than Stage 1. An increase in concentration for the longer extraction periods (Stage 3-3 days and Stage 6-30 days) is apparent, with this effect being much greater for Stage 6 than for Stage 3.

The uranium concentrations in the $\mathrm{Ca}(\mathrm{OH})_{2}$ extracts are dramatically lower than those of the other two leachants, with a peak concentration of $1,740 \mu \mathrm{g} / \mathrm{L}$ observed in the Stage 1 extract. Stages 2 through 6 had uranium concentrations that were significantly less than Stage 1. In addition, no significant kinetic rebound effect was observed in the $\mathrm{Ca}(\mathrm{OH})_{2}$ extracts for Stages 3 and 6 . These results suggest that a secondary uranium phase of lower solubility may have formed during contact with the $\mathrm{Ca}(\mathrm{OH})_{2}$ extracts; however, as discussed below, this phase could not be identified by geochemical modeling calculations of mineral saturation indices for the leachate solutions. Note that the lowest leachate uranium concentrations correspond to this leachant with the highest $\mathrm{pH}$ values (11.5 to 11.8). 
Table 4.12. C-202 Leach Test Results for Uranium (concentration units are $\mu \mathrm{g} / \mathrm{L}$ ) (from Deutsch et al. 2007c)

\begin{tabular}{||l|c|c|c||}
\hline \multirow{2}{*}{\multicolumn{1}{|c|}{ Sample Number }} & DDI Water & $\mathrm{Ca}(\mathrm{OH})_{2}$ & $\mathrm{CaCO}_{3}$ \\
\cline { 2 - 4 } & 19250 & 19250 & 19250 \\
\hline \hline \multicolumn{4}{|c|}{ Single-Contact Tests ${ }^{\text {(a) }}$} \\
\hline 1 month & 42,000 & $11.5-11.8$ & $7.6-9.0$ \\
\hline 1 month (dup) & 27,000 & 683 & 51,300 \\
\hline \multicolumn{4}{|c|}{ Sequential-Contact Tests } \\
\hline Stage 1 (1d) & 33,200 & 1,090 & 55,600 \\
\hline Stage 1 (dup) & 35,300 & 1,740 & 52,400 \\
\hline Stage 2 (1d) & 9,380 & 169 & 9,880 \\
\hline Stage 2 (dup) & 11,600 & 166 & 10,300 \\
\hline Stage 3 (3d) & 14,500 & 127 & 18,500 \\
\hline Stage 3 (dup) & 11,500 & 122 & 29,000 \\
\hline Stage 4 (1d) & 6,120 & 45.2 & 8,790 \\
\hline Stage 4 (dup) & 4,840 & 118 & 10,200 \\
\hline Stage 5 (1d) & 4,080 & 88.7 & 79,000 \\
\hline Stage 5 (dup) & 4,560 & 101 & 68,800 \\
\hline Stage 6 (30d) & 46,600 & 65.1 & 20,700 \\
\hline Stage 6 (dup) & 29,100 & 13.1 & 61,100 \\
\hline (a) 1-day single-contact test results are shown in the Stage 1 sequential-contact results. \\
\hline
\end{tabular}

To evaluate the possibility that equilibrium solubility of a uranium mineral could be controlling dissolved uranium concentrations in these extracts, mineral saturation indices (SIs) were calculated. The saturation index is defined as $\mathrm{SI}=\log \left(\mathrm{Q} / \mathrm{K}_{\mathrm{sp}}\right)$, were $\mathrm{Q}$ is the activity product and $\mathrm{K}_{\mathrm{sp}}$ is the solubility product at equilibrium. Mineral SIs can be used to identify solid phases in equilibrium with the compositions of the leachates.

Minerals with SI values near zero $(\sim \pm 0.5)$ are generally considered to be near equilibrium with the solution composition. More positive values are considered oversaturated, and more negative values are considered undersaturated.

Appendix I (Deutsch et al. 2007a) contains the solution composition data used for the geochemical modeling SI calculations. The React module of The Geochemist's Workbench Version 6.02 (Bethke 2006) was used to calculate the mineral SIs for these solutions. The thermodynamic database thermo.com.V8.R6+.dat was used with modifications that include solubility data for čejkaite $\left[\mathrm{Na}_{4}\left(\mathrm{UO}_{2}\right)\left(\mathrm{CO}_{3}\right)_{3}\right]$ (Felmy et al. 2005), becquerelite $\left[\mathrm{Ca}\left(\mathrm{UO}_{2}\right)_{6} \mathrm{O}_{4}(\mathrm{OH})_{6} \cdot 8 \mathrm{H}_{2} \mathrm{O}\right]$ (Rai et al. 2002), sodium diuranate hydrate $\left[\mathrm{Na}_{2} \mathrm{U}_{2} \mathrm{O}_{7} \cdot \mathrm{xH}_{2} \mathrm{O}\right]$ (Yamamura et al. 1998), an estimated value for Ca-autunite $\left[\mathrm{Ca}\left(\mathrm{UO}_{2}\right)_{2}\left(\mathrm{PO}_{4}\right)_{2}\right]$ (Langmuir 1978), and the stability constant for the dissolved species $\mathrm{Ca}_{2} \mathrm{UO}_{2}\left(\mathrm{CO}_{3}\right)_{3}{ }^{0}$ (aq) (Kalmykov and Choppin 2000). The poorly crystalline phase $\left[\mathrm{Na}_{2} \mathrm{U}_{2} \mathrm{O}_{7} \cdot \mathrm{xH}_{2} \mathrm{O}\right]$ (Yamamura et al. 1998) will be referred to as $\mathrm{Na}_{2} \mathrm{U}_{2} \mathrm{O}_{7}(\mathrm{am})$. Results of the SI calculations for the three different C-202 waste leachates are presented in Tables 4.13 through 4.15. 
Table 4.13. Calculated Saturation Indices (unitless) for Uranium Phases in Tank C-202 DDI Water Extractions (from Deutsch et al. 2007a)

\begin{tabular}{||l|c|c|c|c|c|c|c||}
\hline \multicolumn{1}{|c|}{ Phase } & 1 Month & $\begin{array}{c}\text { Stage 1 } \\
(1 \text { day })\end{array}$ & $\begin{array}{c}\text { Stage 2 } \\
(1 \text { day })\end{array}$ & $\begin{array}{c}\text { Stage 3 } \\
(3 \text { days })\end{array}$ & $\begin{array}{c}\text { Stage 4 } \\
(1 \text { day })\end{array}$ & $\begin{array}{c}\text { Stage 5 } \\
(1 \text { day })\end{array}$ & $\begin{array}{c}\text { Stage 6 } \\
(30 \text { days })\end{array}$ \\
\hline \hline čejkaite $\mathrm{Na}_{4}\left(\mathrm{UO}_{2}\right)\left(\mathrm{CO}_{3}\right)_{3}$ & $<-3$ & $<-3$ & $<-3$ & $<-3$ & $<-3$ & $<-3$ & $<-3$ \\
\hline $\mathrm{Na}_{2} \mathrm{U}_{2} \mathrm{O}_{7}(\mathrm{c})$ & -2.02 & $<-3$ & $<-3$ & -1.97 & $<-3$ & $<-3$ & -1.15 \\
\hline $\mathrm{Na}_{2} \mathrm{U}_{2} \mathrm{O}_{7}(\mathrm{am})$ & $<-3$ & $<-3$ & $<-3$ & $<-3$ & $<-3$ & $<-3$ & $<-3$ \\
\hline $\begin{array}{l}\text { becquerelite } \\
\mathrm{Ca}\left(\mathrm{UO}_{2}\right)_{6} \mathrm{O}_{4}(\mathrm{OH})_{6} \cdot 8 \mathrm{H}_{2} \mathrm{O}\end{array}$ & $<-3$ & $<-3$ & $<-3$ & -0.65 & $<-3$ & $<-3$ & 1.63 \\
\hline schoepite $\mathrm{UO}_{3} \cdot 2 \mathrm{H}_{2} \mathrm{O}$ & -1.33 & -1.13 & -0.43 & -0.11 & -0.28 & -0.25 & 0.21 \\
\hline $\begin{array}{l}\mathrm{Ca}-a u t u n i t e \\
\mathrm{Ca}\left(\mathrm{UO}_{2}\right)_{2}\left(\mathrm{PO}_{4}\right)_{2}\end{array}$ & 1.27 & 2.82 & 4.21 & 3.90 & 4.46 & 4.19 & -0.23 \\
\hline$\left(\mathrm{UO}_{2}\right)_{3}\left(\mathrm{PO}_{4}\right)_{2} \cdot 4 \mathrm{H}_{2} \mathrm{O}$ & $<-3$ & -1.83 & 0.41 & -0.53 & 1.82 & 1.88 & - \\
\hline \hline
\end{tabular}

Table 4.14. Calculated Saturation Indices (unitless) for Uranium Phases in Tank C-202 $\mathrm{Ca}(\mathrm{OH})_{2}$ Extractions (from Deutsch et al. 2007a)

\begin{tabular}{||l|c|c|c|c|c|c|c||}
\hline \multicolumn{1}{|c|}{ Phase } & 1 Month & $\begin{array}{c}\text { Stage 1 } \\
(1 \text { day })\end{array}$ & $\begin{array}{c}\text { Stage 2 } \\
(1 \text { day })\end{array}$ & $\begin{array}{c}\text { Stage 3 } \\
(3 \text { days })\end{array}$ & $\begin{array}{c}\text { Stage 4 } \\
(1 \text { day) }\end{array}$ & $\begin{array}{c}\text { Stage 5 } \\
(1 \text { day })\end{array}$ & $\begin{array}{c}\text { Stage 6 } \\
(30 \text { days })\end{array}$ \\
\hline \hline čejkaite $\mathrm{Na}_{4}\left(\mathrm{UO}_{2}\right)\left(\mathrm{CO}_{3}\right)_{3}$ & $<-3$ & $<-3$ & $<-3$ & $<-3$ & $<-3$ & $<-3$ & $<-3$ \\
\hline $\mathrm{Na}_{2} \mathrm{U}_{2} \mathrm{O}_{7}(\mathrm{c})$ & 0.01 & 0.53 & $<-3$ & $<-3$ & $<-3$ & $<-3$ & $<-3$ \\
\hline $\mathrm{Na}_{2} \mathrm{U}_{2} \mathrm{O}_{7}(\mathrm{am})$ & $<-3$ & $<-3$ & $<-3$ & $<-3$ & $<-3$ & $<-3$ & $<-3$ \\
\hline $\begin{array}{l}\text { becquerelite } \\
\mathrm{Ca}\left(\mathrm{UO}_{2}\right)_{6} \mathrm{O}_{4}(\mathrm{OH})_{6} \cdot 8 \mathrm{H}_{2} \mathrm{O}\end{array}$ & $<-3$ & $<-3$ & $<-3$ & $<-3$ & $<-3$ & $<-3$ & $<-3$ \\
\hline schoepite $\mathrm{UO}_{3} \cdot 2 \mathrm{H}_{2} \mathrm{O}$ & -2.97 & -2.74 & $<-3$ & $<-3$ & $<-3$ & $<-3$ & $<-3$ \\
\hline $\begin{array}{l}\mathrm{Ca}-\text { autunite } \\
\mathrm{Ca}\left(\mathrm{UO}_{2}\right)_{2}\left(\mathrm{PO}_{4}\right)_{2}\end{array}$ & $<-3$ & $<-3$ & $<-3$ & $<-3$ & $<-3$ & $<-3$ & $<-3$ \\
\hline$\left(\mathrm{UO}_{2}\right)_{3}\left(\mathrm{PO}_{4}\right)_{2} \cdot 4 \mathrm{H}_{2} \mathrm{O}$ & $<-3$ & $<-3$ & $<-3$ & $<-3$ & $<-3$ & $<-3$ & $<-3$ \\
\hline
\end{tabular}

Table 4.15. Calculated Saturation Indices (unitless) for Uranium Phases in Tank C-202 $\mathrm{CaCO}_{3}$ Extractions (from Deutsch et al. 2007a)

\begin{tabular}{||l|c|c|c|c|c|c|c||}
\hline \multicolumn{1}{|c|}{ Phase } & 1 Month & $\begin{array}{c}\text { Stage 1 } \\
(1 \text { day })\end{array}$ & $\begin{array}{c}\text { Stage 2 } \\
(1 \text { day) }\end{array}$ & $\begin{array}{c}\text { Stage 3 } \\
(3 \text { days })\end{array}$ & $\begin{array}{c}\text { Stage 4 } \\
(1 \text { day) }\end{array}$ & $\begin{array}{c}\text { Stage 5 } \\
(1 \text { day) }\end{array}$ & $\begin{array}{c}\text { Stage 6 } \\
(30 \text { days })\end{array}$ \\
\hline \hline čejkaite $\mathrm{Na}_{4}\left(\mathrm{UO}_{2}\right)\left(\mathrm{CO}_{3}\right)_{3}$ & $<-3$ & $<-3$ & $<-3$ & $<-3$ & $<-3$ & $<-3$ & $<-3$ \\
\hline $\mathrm{Na}_{2} \mathrm{U}_{2} \mathrm{O}_{7}(\mathrm{c})$ & -2.36 & -1.99 & $<-3$ & -2.60 & $<-3$ & $<-3$ & $<-3$ \\
\hline $\mathrm{Na}_{2} \mathrm{U}_{2} \mathrm{O}_{7}(\mathrm{am})$ & $<-3$ & $<-3$ & $<-3$ & $<-3$ & $<-3$ & $<-3$ & $<-3$ \\
\hline $\begin{array}{l}\text { becquerelite } \\
\mathrm{Ca}\left(\mathrm{UO}_{2}\right)_{6} \mathrm{O}_{4}(\mathrm{OH})_{6} \cdot 8 \mathrm{H}_{2} \mathrm{O}\end{array}$ & $<-3$ & $<-3$ & $<-3$ & -2.16 & -1.93 & $<-3$ & -2.48 \\
\hline schoepite $\mathrm{UO}_{3} \cdot 2 \mathrm{H}_{2} \mathrm{O}$ & -1.47 & -1.44 & -0.55 & -0.34 & -0.15 & -0.36 & -0.40 \\
\hline $\begin{array}{l}\mathrm{Ca}-\text { autunite } \\
\mathrm{Ca}\left(\mathrm{UO}_{2}\right)_{2}\left(\mathrm{PO}_{4}\right)_{2}\end{array}$ & 1.00 & 0.68 & 3.88 & 3.61 & 3.91 & 3.16 & 2.82 \\
\hline$\left(\mathrm{UO}_{2}\right)_{3}\left(\mathrm{PO}_{4}\right)_{2} \cdot 4 \mathrm{H}_{2} \mathrm{O}$ & $<-3$ & $<-3$ & -0.24 & -0.89 & 0.47 & -0.28 & -1.80 \\
\hline \hline
\end{tabular}


Saturation index results for most of the uranium phases in the deionized water extracts of tank C-202 waste (Table 4.13) are significantly undersaturated. Schoepite $\left[\mathrm{UO}_{3} \cdot 2 \mathrm{H}_{2} \mathrm{O}\right]$ appears to be near saturation only in the later extracts. Calcium-autunite calculates to be highly oversaturated, which suggests that this phase is not limiting the dissolved uranium concentration. The SI results for $\left(\mathrm{UO}_{2}\right)_{3}\left(\mathrm{PO}_{4}\right)_{2} \cdot 4 \mathrm{H}_{2} \mathrm{O}$ are erratic. These modeling results suggest that schoepite or some other unidentified phase not in the model's database is limiting the dissolved uranium concentration in the later extracts. Although uranium makes up a substantial portion of the C-202 post-retrieval waste (23.6 wt\%), no crystalline phases were identified by XRD. Precipitation of uranyl phosphates may be kinetically inhibited. For example, Wellman et al. (2005) observed the progressive conversion of uranyl-oxyhydroxides to uranyl-silicates and finally to uranyl-phosphate over a period of 1 to 2 months in a concrete matrix.

Saturation index results for uranium phases in the $\mathrm{Ca}(\mathrm{OH})_{2}$ saturated extracts are all very undersaturated, with the exception of $\mathrm{Na}_{2} \mathrm{U}_{2} \mathrm{O}_{7}$ (c), which is near saturation in the initial extracts. These results indicate that some unidentified phase is controlling the dissolved uranium concentrations in these extracts or that dissolution/precipitation is kinetically inhibited and the dissolved uranium concentration is not controlled by mineral solubility equilibrium.

The SI results for čejkaite, $\mathrm{Na}_{2} \mathrm{U}_{2} \mathrm{O}_{7}(\mathrm{c}), \mathrm{Na}_{2} \mathrm{U}_{2} \mathrm{O}_{7}(\mathrm{am})$, and becquerelite in the $\mathrm{CaCO}_{3}$-saturated extracts are all very undersaturated. Schoepite and $\left(\mathrm{UO}_{2}\right)_{3}\left(\mathrm{PO}_{4}\right)_{2}{ }_{4} \mathrm{H}_{2} \mathrm{O}$ approach saturation in some of the later extracts. Calcium-autunite is generally highly oversaturated in the $\mathrm{CaCO}_{3}$ extracts. It would appear that schoepite or some other unidentified phase is controlling the dissolved uranium concentration in the $\mathrm{CaCO}_{3}$ extracts.

\subsubsection{Technetium-99}

Technetium-99 was measured at a total concentration of $0.23 \mu \mathrm{g} / \mathrm{g}$-dry wt in tank C-202 residual waste (Table 2.5; Deutsch et al. 2007c). This concentration is too low to allow for detecting crystalline technetium mineral phases by XRD analysis. Technetium was also not detected in any of the particles analyzed by SEM/EDS. Because of this lack of identification of technetium-containing solid phases, the focus of this discussion is on its leachability from the waste.

Technetium-99 concentrations measured in the C-202 residual waste leachate solutions are shown in Table 4.16. The amounts of technetium-99 leached in terms of percentages are discussed in Section 4.4.5. The concentrations in each of the waste leachate solutions are generally quite low. Differences in the technetium-99 extractability between the three leachate solutions are minor, with the DDI water extracts producing the only concentrations above the EQL. The highest measured concentration was $0.077 \mu \mathrm{g} / \mathrm{L}$ in Stage 1 of the DDI water extract.

\subsubsection{Chromium}

Chromium was measured at a total concentration of $13,300 \mu \mathrm{g} / \mathrm{g}$ dry wt $(1.3 \%)$ in tank C-202 residual waste (Table 2.5; Deutsch et al. 2007c). No crystalline chromium mineral phases were detected by XRD analysis. These results indicate that the bulk of chromium present in C-202 residual waste occurs in amorphous phases. SEM/EDS analysis indicated that chromium was generally associated with iron oxides. Because of this lack of identification of discrete chromium solid phases, the focus of this discussion is on its leachability from the waste. 
Table 4.16. C-202 Technetium Leach Test Results (concentration units are $\mu \mathrm{g} / \mathrm{L}$ ) (from Deutsch et al. 2007c)

\begin{tabular}{|c|c|c|c|}
\hline \multirow[b]{2}{*}{ Sample Number } & DDI Water & $\mathrm{Ca}(\mathrm{OH})_{2}$ & $\mathrm{CaCO}_{3}$ \\
\hline & 19250 & 19250 & 19250 \\
\hline $\mathrm{pH}$ & $7.4-9.0$ & $11.5-11.8$ & $7.6-9.0$ \\
\hline \multicolumn{4}{|c|}{ Single-Contact Tests ${ }^{(a)}$} \\
\hline 1 month & 0.0683 & $(0.0448)$ & $(0.0400)$ \\
\hline 1 month (dup) & $(0.0410)$ & 0.0540 & $(0.0410)$ \\
\hline \multicolumn{4}{|c|}{ Sequential-Contact Tests } \\
\hline Stage 1 (1d) & 0.0520 & $(0.0315)$ & $(0.0390)$ \\
\hline Stage 1 (dup) & 0.0770 & $(0.0450)$ & $(0.0370)$ \\
\hline Stage 2 (1d) & $(0.0160)$ & $<0.050$ & $<0.050$ \\
\hline Stage 2 (dup) & $(0.0100)$ & $<0.050$ & $<0.050$ \\
\hline Stage 3 (3d) & $(0.00900)$ & $<0.050$ & $<0.050$ \\
\hline Stage 3 (dup) & 0.00400 & $<0.050$ & $<0.050$ \\
\hline Stage 4 (1d) & $(0.00200)$ & $<0.050$ & $<0.050$ \\
\hline Stage 4 (dup) & $<0.050$ & $<0.050$ & $<0.050$ \\
\hline Stage $5(1 d)$ & $<0.050$ & $<0.050$ & $<0.050$ \\
\hline Stage 5 (dup) & $<0.050$ & $<0.050$ & $<0.050$ \\
\hline Stage 6 (30d) & $<0.050$ & $(0.0130)$ & $<0.050$ \\
\hline Stage 6 (dup) & $<0.050$ & $(0.0140)$ & $<0.050$ \\
\hline
\end{tabular}

Chromium concentrations measured in the C-202 extracts are shown in Table 4.17. Measurable concentrations were found in all the extracts. The highest chromium concentrations were observed in the $\mathrm{Ca}(\mathrm{OH})_{2}$ extracts, with the 1-month single contacts being exceptionally high (up to 7,070 $\mu \mathrm{g} / \mathrm{L}$ ). Results for the DDI water and $\mathrm{CaCO}_{3}$ extracts were similar. For all three extraction solutions, Stages 2 through 5 were significantly less than the 1-month single-contact and Stage 1 and 6 extractions. Kinetic rebound effects are again observed for Stages 3 and 6. The higher leachability of chromium using the $\mathrm{Ca}(\mathrm{OH})_{2}$ leachant may be due to the greater solubility of iron oxides under the high $\mathrm{pH}$ conditions (11.5 to 11.8) of this extraction or the propensity to convert from $\mathrm{Cr}^{3+}$ hydroxide to chromate under such conditions (see Figure 3.10, upper right-hand side of the stability field).

\subsubsection{Nitrate}

Nitrate was measured at a total concentration of 3,540 $\mu \mathrm{g} / \mathrm{g}$ dry wt. in tank C-202 residual waste (Table 2.3; Deutsch et al. 2007c). No crystalline nitrate mineral phases were detected by XRD analysis. SEM/EDS analysis did not indicate the presence of any nitrogen-containing particles. Because of this lack of identification of nitrate-containing solid phases, the focus of this discussion is on its leachability from the waste. 
Table 4.17. C-202 Chromium Leach Test Results (ICP-MS) (concentration units are $\mu \mathrm{g} / \mathrm{L}$ ) (from Deutsch et al. 2007c)

\begin{tabular}{|c|c|c|c|}
\hline \multirow[b]{2}{*}{ Sample Number } & DDI Water & $\mathrm{Ca}(\mathrm{OH})_{2}$ & $\mathrm{CaCO}_{3}$ \\
\hline & 19250 & 19250 & 19250 \\
\hline $\mathrm{pH}$ & $7.4-9.0$ & $11.5-11.8$ & $7.6-9.0$ \\
\hline \multicolumn{4}{|c|}{ Single-Contact Tests ${ }^{(a)}$} \\
\hline 1 month & 1,380 & 7,070 & 1,340 \\
\hline 1 month (dup) & 1,070 & 6,220 & 1,290 \\
\hline \multicolumn{4}{|c|}{ Sequential-Contact Tests } \\
\hline Stage 1 (1d) & 1,060 & 1,350 & 1,340 \\
\hline Stage 1 (dup) & 1,050 & 1,420 & 1,230 \\
\hline Stage 2 (1d) & 423 & 788 & 175 \\
\hline Stage 2 (dup) & 471 & 865 & 208 \\
\hline Stage $3(3 d)$ & 752 & 1,440 & 529 \\
\hline Stage 3 (dup) & 714 & 1,470 & 997 \\
\hline Stage 4 (1d) & 295 & 939 & 166 \\
\hline Stage 4 (dup) & 253 & 1,010 & 246 \\
\hline Stage $5(1 \mathrm{~d})$ & 162 & 345 & 20.8 \\
\hline Stage 5 (dup) & 238 & 415 & 23.6 \\
\hline Stage $6(30 d)$ & 1,500 & 2,560 & 707 \\
\hline Stage 6 (dup) & 1,590 & 2,830 & 2,000 \\
\hline
\end{tabular}

Nitrate concentrations measured in the C-202 extracts are shown in Table 4.18. Measurable concentrations were detected in all the extracts. Large differences were not apparent among the three extractants. The highest concentrations were observed in the $\mathrm{Ca}(\mathrm{OH})_{2}$ extracts, with the 1-month single contact having the maximum concentration of $17,900 \mu \mathrm{g} / \mathrm{L}$. Concentrations measured in the 1-month single-contact extractions were all fairly similar. Comparison of nitrate concentrations in the Stage 1 sequential (1-day contact) and 1-month single-contact extractions indicates that the kinetics of nitrate dissolution is somewhat slower in the DDI water extracts than for the other two extractants. These results suggest that the $\mathrm{Ca}(\mathrm{OH})_{2}$ and $\mathrm{CaCO}_{3}$ extractants increase the rate of nitrate dissolution from this residual waste. The kinetic rebound effect is again observed for all extractants for Stages 3 and 6.

\subsubsection{Percentage Leachable Contaminants of Interest}

Percentages of the most important contaminants of interest (technetium-99 and uranium-238) released during the 1-month single-contact and sequential-contact leaching tests from tank C-202 residual waste relative to fusion results are shown in Table 4.19. The percentages of technetium-99 that were leachable were quite low. Only the 1-month single-contact and Stage 1 of the periodic replenishment tests were above the EQL or detection limit. The percentages of leachable uranium-238 were quite low. The 1-month single-contact, Stage 1, and Stage 6 had the highest percentages of leachable uranium-238 for all leachant solutions. 
Table 4.18. C-202 Nitrate Leach Test Results (concentration units are $\mu \mathrm{g} / \mathrm{L}$ ) (from Deutsch et al. 2007c)

\begin{tabular}{|c|c|c|c|}
\hline \multirow[b]{2}{*}{ Sample Number } & DDI Water & $\mathrm{Ca}(\mathrm{OH})_{2}$ & $\mathrm{CaCO}_{3}$ \\
\hline & 19250 & 19250 & 19250 \\
\hline $\mathrm{pH}$ & $7.4-9.0$ & $11.5-11.8$ & $7.6-9.0$ \\
\hline \multicolumn{4}{|c|}{ Single-Contact Tests ${ }^{(a)}$} \\
\hline 1 month & 15,400 & 17,900 & 14,600 \\
\hline 1 month (dup) & 11,900 & 16,900 & 14,000 \\
\hline \multicolumn{4}{|c|}{ Sequential-Contact Tests } \\
\hline Stage 1 (1d) & 8,810 & 12,100 & 9,800 \\
\hline Stage 1 (dup) & 8,470 & 12,100 & 10,100 \\
\hline Stage $2(1 \mathrm{~d})$ & 640 & 8,500 & 784 \\
\hline Stage 2 (dup) & 604 & 10,100 & 682 \\
\hline Stage $3(3 d)$ & 3,260 & 4,580 & 2,950 \\
\hline Stage 3 (dup) & 3,380 & 6,480 & 2,670 \\
\hline Stage $4(1 \mathrm{~d})$ & 1,390 & 563 & 1,070 \\
\hline Stage 4 (dup) & 1,320 & 782 & 1,080 \\
\hline Stage $5(1 \mathrm{~d})$ & 1,580 & 640 & 991 \\
\hline Stage 5 (dup) & 1,590 & 851 & 940 \\
\hline Stage 6 (30d) & 8,450 & 1,610 & 7,920 \\
\hline Stage 6 (dup) & 9,130 & 1,890 & 8,250 \\
\hline
\end{tabular}

Table 4.19. Percentages of Technetium-99 and Uranium-238 Released During Leaching Tests from Tank C-202 Residual Waste Relative to Fusion Results (from Deutsch et al. 2007c)

\begin{tabular}{|c|c|c|}
\hline \multirow[b]{2}{*}{ Leachate } & Technetium-99 & Uranium-238 \\
\hline & \multicolumn{2}{|c|}{ (\% Leachable) } \\
\hline \multicolumn{3}{|c|}{ 1-Month Single-Contact } \\
\hline C-106 Water Leach Range & 4.6 & 2.1 \\
\hline $\mathrm{C}-106 \mathrm{Ca}(\mathrm{OH})_{2}$ Range & 3.0 & 0.03 \\
\hline $\mathrm{C}-106 \mathrm{CaCO}_{3}$ Range & $(3.5)$ & 3.0 \\
\hline \multicolumn{3}{|c|}{ Stage 1} \\
\hline C-106 Water Leach & 6.3 & 2.4 \\
\hline $\mathrm{C}-106 \mathrm{Ca}(\mathrm{OH})_{2}$ & $(3.5)$ & 0.09 \\
\hline $\mathrm{C}-106 \mathrm{CaCO}_{3}$ & $(3.4)$ & 3.5 \\
\hline \multicolumn{3}{|c|}{ Stage 2} \\
\hline C-106 Water Leach & $(1.3)$ & 0.7 \\
\hline $\mathrm{C}-106 \mathrm{Ca}(\mathrm{OH})_{2}$ & BDL & 0.01 \\
\hline $\mathrm{C}-106 \mathrm{CaCO}_{3}$ & $\mathrm{BDL}$ & 0.64 \\
\hline \multicolumn{3}{|c|}{ Stage 3} \\
\hline C-106 Water Leach & $(0.6)$ & 0.9 \\
\hline $\mathrm{C}-106 \mathrm{Ca}(\mathrm{OH})_{2}$ & $\mathrm{BDL}$ & 0.01 \\
\hline $\mathrm{C}-106 \mathrm{CaCO}_{3}$ & BDL & 1.5 \\
\hline
\end{tabular}


Table 4.19. (contd)

\begin{tabular}{|c|c|c|}
\hline & Technetium-99 & Uranium-238 \\
\hline & \multicolumn{2}{|c|}{ (\% Leachable) } \\
\hline \multicolumn{3}{|c|}{$\begin{array}{l}\text { Stage } 4 \\
\end{array}$} \\
\hline C-106 Water Leach & $\mathrm{BDL}$ & 0.4 \\
\hline $\mathrm{C}-106 \mathrm{Ca}(\mathrm{OH})_{2}$ & $\mathrm{BDL}$ & 0.01 \\
\hline $\mathrm{C}-106 \mathrm{CaCO}_{3}$ & $\mathrm{BDL}$ & 0.60 \\
\hline \multicolumn{3}{|c|}{ Stage 5} \\
\hline C-106 Water Leach & $\mathrm{BDL}$ & 0.3 \\
\hline $\mathrm{C}-106 \mathrm{Ca}(\mathrm{OH})_{2}$ & $\mathrm{BDL}$ & 0.01 \\
\hline $\mathrm{C}-106 \mathrm{CaCO}_{3}$ & BDL & 0.47 \\
\hline \multicolumn{3}{|c|}{ Stage 6} \\
\hline C-106 Water Leach & $\mathrm{BDL}$ & 2.7 \\
\hline $\mathrm{C}-106 \mathrm{Ca}(\mathrm{OH})_{2}$ & $(1.2)$ & 0.002 \\
\hline $\mathrm{C}-106 \mathrm{CaCO}_{3}$ & $\mathrm{BDL}$ & 2.5 \\
\hline
\end{tabular}

\subsection{Contaminants of Interest in C-203 Residual Waste}

As with the C-202 samples, no phases containing the COIs iodine or technetium were detected by bulk XRD or SEM/EDS analyses of the C-203 residual waste samples. As indicated previously in Section 2.2.3, some of the solid phases may be amorphous or present at concentrations too low for detection by XRD, which requires crystalline phases to be present at 1 to $5 \mathrm{wt} \%$ of the sample. It is most likely that these COIs are present as trace constituents in minerals such as iron oxides or in amorphous solids.

\subsubsection{Uranium}

The average uranium concentration measured in tank C-203 residual waste (Table 2.6; Deutsch et al. $2007 \mathrm{c}$ ) is $586,000 \mu \mathrm{g} / \mathrm{g}$ dry wt $(58.6 \%)$. This average was determined from two samples (19887 and 19961). No crystalline uranium mineral phases were detected by XRD analysis. These results indicate that the bulk of uranium present in C-203 residual waste occurs as amorphous phases. SEM/EDS analysis indicated that a major component of the residual waste was a uranium phase that contained the elements $\mathrm{U}-\mathrm{Na}-\mathrm{C}-\mathrm{O}-\mathrm{P} \pm \mathrm{H}$.

Table 4.20 lists the dissolved concentrations of uranium present for each of the leach tests conducted on the two samples. These results are discussed in detail in Deutsch et al. (2007c). Measurable concentrations of uranium were extractable by all three extractants and at all stages. The highest extractable uranium concentrations occurred in the $\mathrm{CaCO}_{3}$ extracts, with concentrations as high as $449,000 \mu \mathrm{g} / \mathrm{L}$ U. Formation of aqueous carbonate complexes significantly increases the solubility of uranium phases and is the likely reason for the occurrence of the most soluble uranium in the $\mathrm{CaCO}_{3}$ extractions. The highest concentrations in the $\mathrm{CaCO}_{3}$ extracts were observed in the 1-month-single contact and Stages 1 and 6 of the sequential contacts. Stages 2 through 5 had uranium concentrations that were significantly less than Stage 1. A kinetic rebound effect for the longer extraction periods of the 1-month single contact and Stage 6 (30-day contact) of the sequential contact is apparent. 
Table 4.20. C-203 Leach Test Results for Uranium (concentration units are $\mu \mathrm{g} / \mathrm{L}$ ) (from Deutsch et al. 2007c)

\begin{tabular}{|c|c|c|c|c|c|c|}
\hline \multirow[b]{2}{*}{ Sample Number } & \multicolumn{2}{|c|}{ DDI Water } & \multicolumn{2}{|c|}{$\mathrm{Ca}(\mathrm{OH})_{2}$} & \multicolumn{2}{|c|}{$\mathrm{CaCO}_{3}$} \\
\hline & 19887 & 19961 & 19887 & 19961 & 19887 & 19961 \\
\hline $\mathrm{pH}$ & $9.9-10.7$ & $9.9-10.9$ & $11.6-11.9$ & $11.9-12.9$ & $9.3-10.5$ & $8.0-10.5$ \\
\hline \multicolumn{7}{|c|}{ Single-Contact Tests ${ }^{(a)}$} \\
\hline 1 month & 155,000 & 235,000 & 3,100 & - & 449,000 & 435,000 \\
\hline 1 month (dup) & 155,000 & 116,000 & 3,120 & - & 150,000 & 505,000 \\
\hline \multicolumn{7}{|c|}{ Sequential-Contact Tests } \\
\hline Stage $1(1 \mathrm{~d})$ & 385,000 & 746,000 & 1,870 & 5,000 & 126,000 & 229,000 \\
\hline Stage 1 (dup) & 408,000 & 524,000 & 5,250 & 4,650 & 173,000 & 193,000 \\
\hline Stage $2(1 \mathrm{~d})$ & 163,000 & 81,600 & 465 & 2,760 & 139,000 & 77,100 \\
\hline Stage 2 (dup) & 136,000 & 148,000 & 1,240 & 1,850 & 29,900 & 37,300 \\
\hline Stage $3(3 d)$ & 187,000 & 95,900 & 391 & 694 & 26,600 & 25,900 \\
\hline Stage 3 (dup) & 130,000 & 127,000 & 94.4 & 813 & 43,700 & 60,500 \\
\hline Stage $4(1 \mathrm{~d})$ & 38,600 & 22,400 & 159 & 110 & 33,200 & 11,800 \\
\hline Stage 4 (dup) & 26,700 & 21,600 & 131 & 127 & 21,900 & 13,500 \\
\hline Stage $5(1 \mathrm{~d})$ & 35,600 & 30,000 & 49.7 & 52.6 & 26,700 & 20,800 \\
\hline Stage 5 (dup) & 39,400 & 49,700 & 55.0 & 61.5 & 13,000 & 9,550 \\
\hline Stage $6(30 d)$ & 470,000 & 187,000 & 35.4 & 21.3 & 237,000 & 170,000 \\
\hline Stage 6 (dup) & 425,000 & 165,000 & 22.3 & 27.4 & 175,000 & 19,200 \\
\hline
\end{tabular}

The DDI water extracts also had fairly high concentrations of extractable uranium, with concentrations as high as $746,000 \mu \mathrm{g} / \mathrm{L} \mathrm{U}$. The highest concentrations in the DDI water extracts were observed in Stage 1, 1-month single contact, and Stage 6. Stages 2 through 5 had uranium concentrations that were significantly less than Stage 1. A kinetic rebound effect in Stage 6 (30 days) is apparent; however, this was not observed in the 1-month single contact.

The uranium concentrations in the $\mathrm{Ca}(\mathrm{OH})_{2}$ extracts are dramatically lower than those of the other two extracts, with a peak concentration of $5,250 \mu \mathrm{g} / \mathrm{L}$ observed in the Stage 1 extract. Stages 2 through 6 had uranium concentrations that were significantly less than Stage 1. In addition, no significant increase in concentration were observed in the $\mathrm{Ca}(\mathrm{OH})_{2}$ extracts for Stages 3 and 6 . These results suggest that a secondary uranium phase of lower solubility may have formed during contact with the $\mathrm{Ca}(\mathrm{OH})_{2}$ extracts. Note that the $\mathrm{pH}$ of these extracts ( $\mathrm{pH} 11.6$ to 12.9) were higher than those for the DDI water ( $\mathrm{pH} 9.9$ to 10.9) and $\mathrm{CaCO}_{3}$ extracts ( $\mathrm{pH} 8.0$ to 10.5), which may have reduced the solubility of the concentration-limiting uranium phase. The high $\mathrm{pH}$ of the DDI water leachate after contact with this residual waste shows the strong buffering capacity of this material.

The dissolved uranium concentrations in the leachates produced in the C-203 waste extraction tests were used to calculate mineral SIs to identify possible solid phases in equilibrium with the compositions of the leachates. Appendix I (Deutsch et al. 2007c) contains the solution composition data used for the calculations. The React module of The Geochemist's Workbench Version 6.02 (Bethke 2006) was used to calculate the mineral SIs for these solutions. The thermodynamic database thermo.com.V8.R6+.dat was used with modifications that include solubility data for čejkaite $\left[\mathrm{Na}_{4}\left(\mathrm{UO}_{2}\right)\left(\mathrm{CO}_{3}\right)_{3}\right]($ Felmy et al. 2005), becquerelite $\left[\mathrm{Ca}\left(\mathrm{UO}_{2}\right)_{6} \mathrm{O}_{4}(\mathrm{OH})_{6} \cdot 8 \mathrm{H}_{2} \mathrm{O}\right]$ (Rai et al. 2002), sodium diuranate hydrate 
$\left[\mathrm{Na}_{2} \mathrm{U}_{2} \mathrm{O}_{7} \cdot \mathrm{xH}_{2} \mathrm{O}\right]$ (Yamamura et al. 1998), an estimated value for Ca-autunite $\left[\mathrm{Ca}\left(\mathrm{UO}_{2}\right)_{2}\left(\mathrm{PO}_{4}\right)_{2}\right]$ (Langmuir 1978), and the stability constant for the dissolved species $\mathrm{Ca}_{2} \mathrm{UO}_{2}\left(\mathrm{CO}_{3}\right)_{3}$ (aq) (Kalmykov et al. 2000). The poorly crystalline phase $\left[\mathrm{Na}_{2} \mathrm{U}_{2} \mathrm{O}_{7} \cdot \mathrm{xH}_{2} \mathrm{O}\right]$ (Yamamura et al. 1998) will be referred to as $\mathrm{Na}_{2} \mathrm{U}_{2} \mathrm{O}_{7}(\mathrm{am})$.

Results of the saturation index calculations for C-203 post-retrieval waste samples 19887 and 19961 are presented in Tables 4.21 through 4.23, for the DDI extracts, $\mathrm{Ca}(\mathrm{OH})_{2}$-saturated extracts, and $\mathrm{CaCO}_{3^{-}}$ saturated extracts, respectively.

Table 4.21. Calculated Saturation Indices for Significant Phases in Tank C-203 Water Extractions (from Deutsch et al. 2007c)

\begin{tabular}{|c|c|c|c|c|c|c|c|c|}
\hline \multicolumn{9}{|c|}{$\begin{array}{l}\text { DDI Water Extracts (Sample 19887) } \\
\end{array}$} \\
\hline Phase & 1 Day & 1 Month & $\begin{array}{l}\text { Stage } 1 \\
\text { (1 day) }\end{array}$ & $\begin{array}{l}\text { Stage } 2 \\
\text { (1 day) }\end{array}$ & $\begin{array}{l}\text { Stage } 3 \\
\text { (3 days) }\end{array}$ & $\begin{array}{l}\text { Stage } 4 \\
\text { (1 day) }\end{array}$ & $\begin{array}{l}\text { Stage } 5 \\
\text { (1 day) }\end{array}$ & $\begin{array}{c}\text { Stage } 6 \\
\text { (30 days) }\end{array}$ \\
\hline čejkaite $\mathrm{Na}_{4}\left(\mathrm{UO}_{2}\right)\left(\mathrm{CO}_{3}\right)_{3}$ & $<-3$ & $<-3$ & $<-3$ & $<-3$ & $<-3$ & $<-3$ & $<-3$ & $<-3$ \\
\hline $\mathrm{Na}_{2} \mathrm{U}_{2} \mathrm{O}_{7}(\mathrm{c})$ & 4.62 & 2.07 & 4.62 & 4.12 & 3.13 & 1.97 & 0.71 & 4.46 \\
\hline $\mathrm{Na}_{2} \mathrm{U}_{2} \mathrm{O}_{7}(\mathrm{am})$ & 2.1 & -0.44 & 2.1 & 1.61 & 0.62 & -0.54 & -1.80 & 1.95 \\
\hline $\begin{array}{l}\text { becquerelite } \\
\mathrm{Ca}\left(\mathrm{UO}_{2}\right)_{6} \mathrm{O}_{4}(\mathrm{OH})_{6} \cdot 8 \mathrm{H}_{2} \mathrm{O}\end{array}$ & 2.48 & $<-3$ & 2.48 & 3.95 & 5.15 & 1.00 & 1.34 & 7.64 \\
\hline schoepite $\mathrm{UO}_{3} \cdot 2 \mathrm{H}_{2} \mathrm{O}$ & -0.08 & -1.13 & -0.08 & 0.19 & 0.44 & -0.31 & -0.14 & 0.74 \\
\hline Ca-autunite $\mathrm{Ca}\left(\mathrm{UO}_{2}\right)_{2}\left(\mathrm{PO}_{4}\right)_{2}$ & -0.07 & -2.12 & -0.07 & 0.16 & 2.18 & -1.34 & 0.57 & 1.68 \\
\hline $\mathrm{Fe}(\mathrm{OH})_{3}$ & 1.47 & 1.06 & 1.47 & 1.09 & 1.58 & 0.34 & 0.99 & 1.33 \\
\hline gibbsite $\mathrm{Al}(\mathrm{OH})_{3}$ & 0.08 & 0.42 & 0.08 & -0.38 & -0.42 & -0.66 & -0.03 & 0.03 \\
\hline calcite $\mathrm{CaCO}_{3}$ & -0.49 & -0.59 & -0.49 & -0.87 & -0.40 & -0.67 & -0.44 & -0.23 \\
\hline \multicolumn{9}{|c|}{ DDI Water Extracts (Sample 19961) } \\
\hline Phase & 1 Day & 1 Month & $\begin{array}{l}\text { Stage } 1 \\
(1 \text { day }) \\
\end{array}$ & $\begin{array}{l}\text { Stage } 2 \\
\text { (1 day) }\end{array}$ & $\begin{array}{l}\text { Stage } 3 \\
\text { (3 days) }\end{array}$ & $\begin{array}{l}\text { Stage } 4 \\
\text { (1 day) }\end{array}$ & $\begin{array}{l}\text { Stage } 5 \\
(1 \text { day }) \\
\end{array}$ & $\begin{array}{c}\text { Stage } 6 \\
\text { (30 days) }\end{array}$ \\
\hline čejkaite $\mathrm{Na}_{4}\left(\mathrm{UO}_{2}\right)\left(\mathrm{CO}_{3}\right)_{3}$ & $<-3$ & $<-3$ & $<-3$ & $<-3$ & $<-3$ & $<-3$ & $<-3$ & $<-3$ \\
\hline $\mathrm{Na}_{2} \mathrm{U}_{2} \mathrm{O}_{7}(\mathrm{c})$ & 6.26 & 3.67 & 6.26 & 3.63 & 3.19 & 1.02 & -0.25 & 2.92 \\
\hline $\mathrm{Na}_{2} \mathrm{U}_{2} \mathrm{O}_{7}(\mathrm{am})$ & 3.75 & 1.16 & 3.75 & 1.12 & 0.68 & -1.49 & -2.76 & 0.41 \\
\hline $\begin{array}{l}\text { becquerelite } \\
\mathrm{Ca}\left(\mathrm{UO}_{2}\right)_{6} \mathrm{O}_{4}(\mathrm{OH})_{6} \cdot 8 \mathrm{H}_{2} \mathrm{O}\end{array}$ & 6.49 & -0.74 & 6.49 & 2.03 & 3.72 & -0.93 & -0.88 & 4.88 \\
\hline schoepite $\mathrm{UO}_{3} \cdot 2 \mathrm{H}_{2} \mathrm{O}$ & 0.54 & -0.61 & 0.54 & -0.14 & 0.15 & -0.59 & -0.51 & 0.42 \\
\hline Ca-autunite $\mathrm{Ca}\left(\mathrm{UO}_{2}\right)_{2}\left(\mathrm{PO}_{4}\right)_{2}$ & 0.70 & -1.35 & 0.70 & -1.14 & 0.14 & -1.80 & -0.21 & 1.67 \\
\hline $\mathrm{Fe}(\mathrm{OH})_{3}$ & 1.52 & 1.42 & 1.52 & 0.80 & 1.12 & 0.43 & 1.07 & 1.28 \\
\hline gibbsite $\mathrm{Al}(\mathrm{OH})_{3}$ & -0.33 & 0.08 & -0.33 & -0.64 & -0.33 & -0.48 & 0.16 & 0.47 \\
\hline calcite $\mathrm{CaCO}_{3}$ & -0.74 & -0.54 & -0.74 & -1.06 & -0.64 & -0.67 & -0.25 & -0.58 \\
\hline
\end{tabular}

Evaluation of the deionized water extract results for uranium minerals indicates that čejkaite is undersaturated throughout all extraction stages. This means that čejkaite, if present in the waste, is dissolving into the water but not at a rate sufficient to achieve equilibrium-dissolved concentrations of its constituents. $\mathrm{Na}_{2} \mathrm{U}_{2} \mathrm{O}_{7}(\mathrm{c}), \mathrm{Na}_{2} \mathrm{U}_{2} \mathrm{O}_{7}(\mathrm{am})$, and becquerelite are generally oversaturated except for some of the later stages where these phases become undersaturated. Because no crystalline phases containing uranium were identified in the C-203 post-retrieval waste by XRD, neither $\mathrm{Na}_{2} \mathrm{U}_{2} \mathrm{O}_{7}$ (c) nor becquerelite are expected to occur in the waste in significant quantities. The high degree of oversaturation with respect to these phases suggests that their formation was kinetically inhibited during the leaching tests. Schoepite is near saturation throughout all DDI leaching stages. Although a number of the SIs calculated for Ca-autunite suggest that this phase could be near equilibrium, many of the autunite SI 
Table 4.22. Calculated Saturation Indices for Significant Phases in Tank C-203 $\mathrm{Ca}(\mathrm{OH})_{2}$ Extractions (from Deutsch et al. 2007c)

\begin{tabular}{|c|c|c|c|c|c|c|c|c|}
\hline \multicolumn{9}{|c|}{$\mathrm{Ca}(\mathrm{OH})_{2}$ Extracts (Sample 19887) } \\
\hline Phase & 1 Day & 1 Month & $\begin{array}{l}\text { Stage } 1 \\
\text { (1 day) }\end{array}$ & $\begin{array}{l}\text { Stage } 2 \\
\text { (1 day) }\end{array}$ & $\begin{array}{l}\text { Stage } 3 \\
(3 \text { days })\end{array}$ & $\begin{array}{l}\text { Stage } 4 \\
\text { (1 day) }\end{array}$ & $\begin{array}{l}\text { Stage } 5(1 \\
\text { day) }\end{array}$ & $\begin{array}{c}\text { Stage } 6 \\
\text { (30 days) }\end{array}$ \\
\hline čejkaite $\mathrm{Na}_{4}\left(\mathrm{UO}_{2}\right)\left(\mathrm{CO}_{3}\right)_{3}$ & $<-3$ & $<-3$ & $<-3$ & $<-3$ & $<-3$ & $<-3$ & $<-3$ & $<-3$ \\
\hline $\mathrm{Na}_{2} \mathrm{U}_{2} \mathrm{O}_{7}(\mathrm{c})$ & 1.40 & 1.80 & 1.40 & -0.02 & -0.35 & -1.22 & -2.96 & $<-3$ \\
\hline $\mathrm{Na}_{2} \mathrm{U}_{2} \mathrm{O}_{7}(\mathrm{am})$ & -1.11 & -0.71 & -1.11 & -2.53 & -2.86 & $<-3$ & $<-3$ & $<-3$ \\
\hline $\begin{array}{l}\text { becquerelite } \\
\mathrm{Ca}\left(\mathrm{UO}_{2}\right)_{6} \mathrm{O}_{4}(\mathrm{OH})_{6} \cdot 8 \mathrm{H}_{2} \mathrm{O}\end{array}$ & $<-3$ & $<-3$ & $<-3$ & $<-3$ & $<-3$ & $<-3$ & $<-3$ & $<-3$ \\
\hline schoepite $\mathrm{UO}_{3} \cdot 2 \mathrm{H}_{2} \mathrm{O}$ & -2.64 & -2.38 & -2.64 & $<-3$ & $<-3$ & $<-3$ & $<-3$ & $<-3$ \\
\hline $\begin{array}{l}\text { Ca-autunite } \\
\mathrm{Ca}\left(\mathrm{UO}_{2}\right)_{2}\left(\mathrm{PO}_{4}\right)_{2}\end{array}$ & $<-3$ & $<-3$ & $<-3$ & -- & -- & -- & -- & -- \\
\hline $\mathrm{Fe}(\mathrm{OH})_{3}$ & -1.36 & -1.39 & -1.36 & -1.60 & -1.53 & -1.42 & -1.41 & -1.48 \\
\hline gibbsite $\mathrm{Al}(\mathrm{OH})_{3}$ & -0.67 & -0.45 & -0.67 & -1.19 & -1.24 & -1.85 & -2.69 & -2.66 \\
\hline calcite $\mathrm{CaCO}_{3}$ & -0.63 & -0.51 & -0.63 & 1.00 & 0.63 & 1.73 & 2.48 & 2.21 \\
\hline \multicolumn{9}{|c|}{$\mathrm{Ca}(\mathrm{OH})_{2}$ Extracts (Sample 19961) } \\
\hline Phase & 1 Day & 1 Month & $\begin{array}{l}\text { Stage } 1 \\
\text { (1 day) }\end{array}$ & $\begin{array}{l}\text { Stage } 2 \\
\text { (1 day) }\end{array}$ & $\begin{array}{l}\text { Stage } 3 \\
(3 \text { days })\end{array}$ & $\begin{array}{l}\text { Stage } 4 \\
\text { (1 day) }\end{array}$ & $\begin{array}{l}\text { Stage } 5 \mathrm{D} \\
(1 \text { day })\end{array}$ & $\begin{array}{c}\text { Stage } 6 \\
(30 \text { days })\end{array}$ \\
\hline čejkaite $\mathrm{Na}_{4}\left(\mathrm{UO}_{2}\right)\left(\mathrm{CO}_{3}\right)_{3}$ & $<-3$ & $<-3$ & $<-3$ & $<-3$ & $<-3$ & $<-3$ & $<-3$ & $<-3$ \\
\hline $\mathrm{Na}_{2} \mathrm{U}_{2} \mathrm{O}_{7}(\mathrm{c})$ & 2.49 & 6.19 & 2.49 & 1.52 & 0.10 & -1.84 & $<-3$ & -- \\
\hline $\mathrm{Na}_{2} \mathrm{U}_{2} \mathrm{O}_{7}(\mathrm{am})$ & -0.02 & 3.68 & -0.02 & -0.99 & -2.41 & $<-3$ & $<-3$ & -- \\
\hline $\begin{array}{l}\text { becquerelite } \\
\mathrm{Ca}\left(\mathrm{UO}_{2}\right)_{6} \mathrm{O}_{4}(\mathrm{OH})_{6} \cdot 8 \mathrm{H}_{2} \mathrm{O}\end{array}$ & $<-3$ & 3.14 & $<-3$ & $<-3$ & $<-3$ & $<-3$ & $<-3$ & -- \\
\hline schoepite $\mathrm{UO}_{3} \cdot 2 \mathrm{H}_{2} \mathrm{O}$ & -2.27 & -0.52 & -2.27 & -2.62 & $<-3$ & $<-3$ & $<-3$ & -- \\
\hline $\begin{array}{l}\text { Ca-autunite } \\
\mathrm{Ca}\left(\mathrm{UO}_{2}\right)_{2}\left(\mathrm{PO}_{4}\right)_{2}\end{array}$ & $<-3$ & $<-3$ & $<-3$ & $<-3$ & -- & -- & -- & -- \\
\hline $\mathrm{Fe}(\mathrm{OH})_{3}$ & -1.57 & 0.18 & -1.57 & -1.56 & -1.73 & -1.41 & -2.05 & -- \\
\hline gibbsite $\mathrm{Al}(\mathrm{OH})_{3}$ & -1.03 & -0.79 & -1.03 & -1.16 & -1.29 & -2.80 & $<-3$ & -- \\
\hline calcite & -0.42 & 0.94 & -0.42 & -1.23 & 0.67 & $<-3$ & $<-3$ & -- \\
\hline
\end{tabular}

values are erratic, with some very high values and some very low values. As a result, it does not appear that this phase is able to exert significant control over the solubility of uranium in the C-203 residual waste. As indicated previously, the formation of uranyl-phosphates appears to be kinetically limited.

The average and standard deviation of the SIs for schoepite $\left(\mathrm{UO}_{3} \cdot 2 \mathrm{H}_{2} \mathrm{O}\right)$ shown in Table 4.21 is $-0.07 \pm 0.53$. These results suggest that this mineral may be present in the residual material. It is also possible that if $\mathrm{Na}_{2} \mathrm{U}_{2} \mathrm{O}_{7}(\mathrm{am})$ may be present in the residual waste because its SI was close to zero for several leachate compositions. Poorly crystalline clarkeite $\left(\mathrm{Na}_{2} \mathrm{U}_{2} \mathrm{O}_{7}\right)$ was tentatively identified in preretrieval C-203 waste (Deutsch et al. 2007c), suggesting the possible occurrence of $\mathrm{Na}_{2} \mathrm{U}_{2} \mathrm{O}_{7}(\mathrm{am})$ in C-203 post-retrieval waste.

The calculated SI results for the $\mathrm{Ca}(\mathrm{OH})_{2}$ extracts in Table 4.22 indicate that čejkaite is undersaturated throughout all extraction stages. With the exception of $\mathrm{Na}_{2} \mathrm{U}_{2} \mathrm{O}_{7}(\mathrm{c})$ in some of the initial sequential leaching stages, all other uranium phases were undersaturated throughout each of the extraction stages. Because no uranium-bearing crystalline phases were identified in the C-203 post-retrieval waste by XRD, 
Table 4.23. Calculated Saturation Indices for Significant Phases in Tank C-203 $\mathrm{CaCO}_{3}$ Extractions (from Deutsch et al. 2007c)

\begin{tabular}{|c|c|c|c|c|c|c|c|c|}
\hline \multicolumn{9}{|c|}{$\mathrm{CaCO}_{3}$ Extracts (Sample 19887) } \\
\hline Phase & 1 Day & 1 Month & $\begin{array}{l}\text { Stage } 1 \\
(1 \text { day })\end{array}$ & $\begin{array}{l}\text { Stage } 2 \\
\text { (1 day) }\end{array}$ & $\begin{array}{l}\text { Stage } 3 \\
\text { (3 days) }\end{array}$ & $\begin{array}{l}\text { Stage } 4 \\
\text { (1 day) }\end{array}$ & $\begin{array}{l}\text { Stage } 5 \\
\text { (1 day) }\end{array}$ & $\begin{array}{l}\text { Stage } 6 \\
\text { (30 days) }\end{array}$ \\
\hline čejkaite $\mathrm{Na}_{4}\left(\mathrm{UO}_{2}\right)\left(\mathrm{CO}_{3}\right)_{3}$ & $<-3$ & $<-3$ & $<-3$ & $<-3$ & $<-3$ & $<-3$ & $<-3$ & $<-3$ \\
\hline $\mathrm{Na}_{2} \mathrm{U}_{2} \mathrm{O}_{7}$ (c) & -1.73 & 2.73 & -1.73 & 2.03 & -1.84 & -0.85 & -1.41 & 1.83 \\
\hline $\mathrm{Na}_{2} \mathrm{U}_{2} \mathrm{O}_{7}(\mathrm{am})$ & $<-3$ & 0.22 & $<-3$ & -0.48 & $<-3$ & $<-3$ & $<-3$ & -0.68 \\
\hline $\begin{array}{l}\text { becquerelite } \\
\mathrm{Ca}\left(\mathrm{UO}_{2}\right)_{6} \mathrm{O}_{4}(\mathrm{OH})_{6} \cdot 8 \mathrm{H}_{2} \mathrm{O}\end{array}$ & $<-3$ & -1.52 & $<-3$ & 0.53 & $<-3$ & -3.00 & $<-3$ & 4.56 \\
\hline schoepite $\mathrm{UO}_{3} \cdot 2 \mathrm{H}_{2} \mathrm{O}$ & -2.44 & -0.71 & -2.44 & -0.32 & -1.25 & -0.72 & -0.82 & 0.37 \\
\hline $\begin{array}{l}\text { Ca-autunite } \\
\mathrm{Ca}\left(\mathrm{UO}_{2}\right)_{2}\left(\mathrm{PO}_{4}\right)_{2}\end{array}$ & -3.0 & -0.56 & -3.0 & 0.73 & -0.33 & 0.35 & -0.11 & 2.74 \\
\hline $\mathrm{Fe}(\mathrm{OH})_{3}$ & 1.33 & 1.60 & 1.33 & 1.60 & 1.16 & 1.11 & 0.96 & 1.76 \\
\hline gibbsite $\mathrm{Al}(\mathrm{OH})_{3}$ & 0.74 & 0.37 & 0.74 & 0.13 & 0.57 & 0.42 & -0.39 & 0.98 \\
\hline calcite $\mathrm{CaCO}_{3}$ & -0.14 & -0.12 & -0.14 & -0.27 & -0.57 & -0.59 & -0.66 & 0.04 \\
\hline \multicolumn{9}{|c|}{$\mathrm{CaCO}_{3}$ Extracts (Sample 19961) } \\
\hline Phase & 1 Day & 1 Month & $\begin{array}{l}\text { Stage } 1 \\
(1 \text { day })\end{array}$ & $\begin{array}{l}\text { Stage } 2 \\
\text { (1 day) }\end{array}$ & $\begin{array}{l}\text { Stage } 3 \\
(3 \text { days })\end{array}$ & $\begin{array}{l}\text { Stage } 4 \\
\text { (1 day) }\end{array}$ & $\begin{array}{l}\text { Stage } 5 \\
\text { (1 day) }\end{array}$ & $\begin{array}{c}\text { Stage } 6 \\
(30 \text { days })\end{array}$ \\
\hline čejkaite $\mathrm{Na}_{4}\left(\mathrm{UO}_{2}\right)\left(\mathrm{CO}_{3}\right)_{3}$ & $<-3$ & $<-3$ & $<-3$ & $<-3$ & $<-3$ & $<-3$ & $<-3$ & $<-3$ \\
\hline $\mathrm{Na}_{2} \mathrm{U}_{2} \mathrm{O}_{7}(\mathrm{c})$ & 2.34 & 3.65 & 2.34 & 0.67 & -1.20 & $<-3$ & -2.48 & -0.42 \\
\hline $\mathrm{Na}_{2} \mathrm{U}_{2} \mathrm{O}_{7}(\mathrm{am})$ & -0.17 & 1.15 & -0.17 & -1.83 & $<-3$ & $<-3$ & $<-3$ & -2.93 \\
\hline $\begin{array}{l}\text { becquerelite } \\
\mathrm{Ca}\left(\mathrm{UO}_{2}\right)_{6} \mathrm{O}_{4}(\mathrm{OH})_{6} \cdot 8 \mathrm{H}_{2} \mathrm{O}\end{array}$ & $<-3$ & 0.87 & $<-3$ & -1.69 & $<-3$ & $<-3$ & $<-3$ & 2.19 \\
\hline schoepite $\mathrm{UO}_{3} \cdot 2 \mathrm{H}_{2} \mathrm{O}$ & -0.92 & -0.34 & -0.92 & -0.60 & -0.95 & -0.45 & -0.75 & 0.26 \\
\hline $\begin{array}{l}\text { Ca-autunite } \\
\mathrm{Ca}\left(\mathrm{UO}_{2}\right)_{2}\left(\mathrm{PO}_{4}\right)_{2}\end{array}$ & -1.43 & -0.03 & -1.43 & 0.42 & -0.33 & 3.29 & 0.85 & 4.43 \\
\hline $\mathrm{Fe}(\mathrm{OH})_{3}$ & 1.51 & 1.70 & 1.51 & 1.42 & 1.02 & 0.98 & 0.92 & 1.76 \\
\hline gibbsite $\mathrm{Al}(\mathrm{OH})_{3}$ & 0.03 & 0.16 & 0.03 & 0.10 & 0.53 & 0.95 & 0.14 & 1.72 \\
\hline calcite $\mathrm{CaCO}_{3}$ & -0.54 & -0.22 & -0.54 & -0.48 & -0.97 & -1.29 & -1.04 & -0.44 \\
\hline
\end{tabular}

$\mathrm{Na}_{2} \mathrm{U}_{2} \mathrm{O}_{7}$ (c) is not expected to occur in significant quantities. As a result of the high $\mathrm{pH}$ of the $\mathrm{Ca}(\mathrm{OH})_{2}$ extracts, schoepite is not stable and cannot limit the dissolved concentration of uranium in this system.

The SI results for the $\mathrm{CaCO}_{3}$ extracts in Table 4.23 are similar to those of the $\mathrm{Ca}(\mathrm{OH})_{2}$ extracts discussed previously, except that some of the $\mathrm{CaCO}_{3}$ extracts appear to be near equilibrium with respect to Ca-autunite. The SI results for Ca-autunite have an average and standard deviation of $0.50 \pm 1.91$. Although the average is near equilibrium, the high variability of the results indicates that this phase is not likely to exert significant control over the dissolved uranium concentration.

Empirical solubility experiments described in detail in Deutsch et al. (2007c) were conducted with several C-203 waste samples in an attempt to determine if $\mathrm{Na}_{2} \mathrm{U}_{2} \mathrm{O}_{7}(\mathrm{am})$ occurs in C-203 post-retrieval waste. The experiments were designed so that if $\mathrm{Na}_{2} \mathrm{U}_{2} \mathrm{O}_{7}(\mathrm{am})$ was the dominant uranium phase in the waste, it would remain stable and control the dissolved concentration of uranium in the experiments. The analytical results of the empirical solubility experiments are provided in Appendix I (Deutsch et al. 2007c). A summary of the mineral SI calculations conducted with these data for $\mathrm{Na}_{2} \mathrm{U}_{2} \mathrm{O}_{7}(\mathrm{am})$ are shown in Table 4.24, and the details are found in the last portion of Appendix J starting on page J.254 (Deutsch et al. 2007c). The saturation indices indicate significant oversaturation of the experimental solutions with 
Table 4.24. $\mathrm{Na}_{2} \mathrm{U}_{2} \mathrm{O}_{7}(\mathrm{am})$ Saturation Indices for C-203 Solubility Experiments (from Deutsch et al. 2007c)

\begin{tabular}{|c|c|c|c|}
\hline \multicolumn{4}{|c|}{ Experiment 1, 1.0 $\mathrm{M} \mathrm{NaNO}_{3}, 0.01 \mathrm{M} \mathrm{NaOH}$} \\
\hline Sample & Stage & Leach Period & $\mathrm{SI} \mathrm{Na}_{2} \mathrm{U}_{2} \mathrm{O}_{7}(\mathrm{am})$ \\
\hline 19661 & 1 & 1 Day & 1.86 \\
\hline 19661 & 2 & 1 Day & 1.19 \\
\hline 19661 & 3 & 1 Week & 0.99 \\
\hline 19661 & 4 & 1 Month & 2.14 \\
\hline 19661 duplicate & 1 & 1 Day & 1.29 \\
\hline 19661 duplicate & 2 & 1 Day & 1.13 \\
\hline 19661 duplicate & 3 & 1 Week & 0.96 \\
\hline 19661 duplicate & 4 & 1 Month & 1.76 \\
\hline 19661 Yellow $^{\mathrm{a}}$ & 1 & 1 Day & 1.64 \\
\hline 19661 Yellow & 2 & 1 Day & 1.19 \\
\hline 19661 Yellow & 3 & 1 Week & 0.97 \\
\hline 19661 Yellow & 4 & 1 Month & 2.17 \\
\hline \multicolumn{4}{|c|}{ Experiment 2, 1.0 M NaNO ${ }_{3}, 0.1 \mathrm{M} \mathrm{NaOH}$} \\
\hline Sample & Stage & Leach Period & $\mathrm{SI} \mathrm{Na}_{2} \mathrm{U}_{2} \mathrm{O}_{7}(\mathrm{am})$ \\
\hline 19661 & 1 & 1 1 Day & 3.51 \\
\hline 19661 & 2 & 1 Day & 3.01 \\
\hline 19661 & 3 & 1 Week & 2.55 \\
\hline 19661 & 4 & 1 Month & 2.00 \\
\hline 19661 duplicate & 1 & 1 Day & 3.49 \\
\hline 19661 duplicate & 2 & 1 Day & 3.04 \\
\hline 19661 duplicate & 3 & 1 Week & 2.53 \\
\hline 19661 duplicate & 4 & 1 Month & 2.21 \\
\hline 19661 Yellow & 1 & 1 Day & 3.94 \\
\hline 19661 Yellow & 2 & 1 Day & 3.61 \\
\hline 19661 Yellow & 3 & 1 Week & 2.76 \\
\hline 19661 Yellow & 4 & 1 Month & 2.16 \\
\hline \multicolumn{4}{|c|}{$\begin{array}{l}\text { Experiment 3, Stage 1-3: } 1.0 \mathrm{M} \mathrm{NaNO}_{3}, 0.01 \mathrm{M} \mathrm{NaOH} \text {, } \\
\text { Stage 4: } 1.0 \mathrm{M} \mathrm{NaNO}_{3}, 0.01 \mathrm{M} \mathrm{NaOH}, 0.001 \mathrm{M} \mathrm{Na}_{2} \mathrm{CO}_{3}\end{array}$} \\
\hline Sample & Stage & Leach Period & $\mathrm{SI} \mathrm{Na}_{2} \mathrm{U}_{2} \mathrm{O}_{7}(\mathrm{am})$ \\
\hline 19661 & 1 & 1 1 Day & 0.67 \\
\hline 19661 & 2 & 1 Day & 0.97 \\
\hline 19661 & 3 & 1 Week & 0.84 \\
\hline 19661 & 4 & 1 Month & 3.76 \\
\hline 19661 duplicate & 1 & 1 Day & 1.12 \\
\hline 19661 duplicate & 2 & 1 Day & 0.98 \\
\hline 19661 duplicate & 3 & 1 Week & 0.94 \\
\hline 19661 duplicate & 4 & 1 Month & 3.90 \\
\hline 19887 Yellow & 1 & 1 Day & 2.21 \\
\hline 19887 Yellow & 2 & 1 Day & 2.41 \\
\hline 19887 Yellow & 3 & 1 Week & 0.97 \\
\hline 19887 Yellow & 4 & 1 Month & 3.39 \\
\hline $\begin{array}{l}\text { (a) Yellow samples } \\
\text { uranium minera }\end{array}$ & colore & erals that were $\mathrm{s}$ & to attempt to identify the \\
\hline
\end{tabular}


respect to $\mathrm{Na}_{2} \mathrm{U}_{2} \mathrm{O}_{7}(\mathrm{am})$ for all the experiments. In experiments 1 and 3, the degree of oversaturation is much higher for the 1-month contact times than for the shorter contact periods.

One possible reason for the high degree of oversaturation with respect to $\mathrm{Na}_{2} \mathrm{U}_{2} \mathrm{O}_{7}(\mathrm{am})$ calculated for these experiments is the presence of a very soluble uranium phase that is dissolving into solution at a higher rate than can be precipitated by $\mathrm{Na}_{2} \mathrm{U}_{2} \mathrm{O}_{7}(\mathrm{am})$. Another possible reason for the high SI values for $\mathrm{Na}_{2} \mathrm{U}_{2} \mathrm{O}_{7}(\mathrm{am})$ is erroneously low carbonate concentration measurements. Because $\mathrm{U}(\mathrm{VI})$ is strongly complexed by dissolved carbonate, increased carbonate concentrations cause an increase in the solubility of uranium minerals. Therefore, erroneously low carbonate concentrations measured in the solutions will result in calculated SI values that are high. The total inorganic carbon (TIC) concentrations used to calculate the carbonate concentration in these experiments appear to be suspect (see Appendix I, Deutsch et al. 2007c). For example, it is known from the water leach experiments and TIC measurements on the waste that significant amounts of carbonate occur in C-203 post-retrieval waste. The results shown in Appendix I (Deutsch et al. 2007c) for experiment 2 indicate negative values for carbonate. The carbonate concentrations were determined from TIC measurements in the experimental solutions by subtracting measured total organic carbon values from measured total carbon values. Because significantly negative values were determined for experiment 2 , it seems likely that the carbonate values determined for experiments 1 and 3 are underestimated. Underestimated carbonate concentrations would result in calculated SI values that are erroneously high.

The method used to calculate activity coefficients in the thermodynamic model may be another possible reason for the high SI values that were calculated for $\mathrm{Na}_{2} \mathrm{U}_{2} \mathrm{O}_{7}(\mathrm{am})$. Because of the relatively high ionic strength of the solutions ( 1 M), the Pitzer ion-interaction model (Pitzer and Mayorga 1973; Pitzer 1991) is the preferred method to account for ionic strength affects. This approach was not used because measured values for the ion-interaction parameters needed for all the species of interest are not currently available. Instead, the "B-dot" method (an extended form of the Debye-Hückel equation) was used to calculate activity coefficients (Helgeson 1969). For the conditions used in the empirical solubility experiments (experiments 1 and 3, in particular), the dominant dissolved uranium species was calculated to be the monovalent $\mathrm{UO}_{2}(\mathrm{OH})_{3}{ }^{-}$species. As a result of the low charge of this species, it is expected that errors due to inaccurate ionic strength corrections were not very significant.

Other reasons for the high $\mathrm{Na}_{2} \mathrm{U}_{2} \mathrm{O}_{7}(\mathrm{am}) \mathrm{SI}$ values include the possible formation of colloidal-size uranium-bearing particles that could pass through the $0.45-\mu \mathrm{m}$ filters used to filter the solutions prior to analysis or the possibility that the $\mathrm{K}_{\mathrm{sp}}$ value of Yamamura et al. (1998) used for this solid is not correct for the phase in our experiments. The noise in results suggests that colloid formation is the more likely cause. An incorrect $\mathrm{K}_{\mathrm{sp}}$ would produce a systematic error. Other researchers measuring the solubility of $\mathrm{U}(\mathrm{VI})$ precipitates have used filters with much smaller pore sizes to avoid this problem (e.g., Yamamura et al. 1998; Rai et al. 2002).

Because of the elevated SI values calculated for $\mathrm{Na}_{2} \mathrm{U}_{2} \mathrm{O}_{7}(\mathrm{am})$ in the solubility experiments, no definitive conclusions could be drawn from the results regarding the likely presence or absence of $\mathrm{Na}_{2} \mathrm{U}_{2} \mathrm{O}_{7}(\mathrm{am})$ in $\mathrm{C}-203$ post-retrieval waste.

\subsubsection{Technetium-99}

Technetium-99 was measured at a total concentration of $0.081 \mu \mathrm{g} / \mathrm{g}$-dry wt in tank C-203 residual waste (Table 2.6; Deutsch et al. 2007c). This concentration is too low to allow for detecting crystalline 
technetium mineral phases by XRD analysis. Technetium was also not detected in any of the particles analyzed by SEM/EDS. Because of this lack of identification of technetium-containing solid phases, the focus of this discussion of technetium is on its leachability from the waste.

Technetium-99 concentrations measured in the C-203 leachate solutions are shown in Table 4.25. The concentrations in each of the waste leachate solutions are low, with no concentrations above the EQL. Differences in the technetium-99 extractability between the three leachate solutions are minor.

Table 4.25. C-203 Leach Test Results for Technetium-99 (concentration units are $\mu \mathrm{g} / \mathrm{L}$ ) (from Deutsch et al. 2007c)

\begin{tabular}{|c|c|c|c|c|c|c|}
\hline \multirow[b]{2}{*}{ Sample Number } & \multicolumn{2}{|c|}{ DDI Water } & \multicolumn{2}{|c|}{$\overline{\mathrm{Ca}(\mathrm{OH})_{2}}$} & \multicolumn{2}{|c|}{ 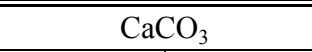 } \\
\hline & 19887 & 19961 & 19887 & 19961 & 19887 & 19961 \\
\hline$\overline{\mathrm{pH}}$ & $9.9-10.7$ & $9.9-10.9$ & $11.6-11.9$ & $11.9-12.9$ & $9.3-10.5$ & $8.0-10.5$ \\
\hline \multicolumn{7}{|c|}{ Single-Contact Tests $^{(a)}$} \\
\hline 1 month & $<0.5$ & $<0.5$ & $<0.5$ & $<0.5$ & $<0.5$ & $(0.16)$ \\
\hline 1 month (dup) & $<0.5$ & $<0.5$ & $<0.5$ & $<0.5$ & $<0.5$ & $(0.09)$ \\
\hline \multicolumn{7}{|c|}{ Sequential-Contact Tests } \\
\hline Stage $1(1 \mathrm{~d})$ & $(0.0312)$ & $(0.0348)$ & $(0.5)$ & $<0.5$ & $<0.5$ & $<0.5$ \\
\hline Stage 1 (dup) & $(0.0303)$ & $(0.0605)$ & $<0.5$ & $<0.5$ & $<0.5$ & $(0.07)$ \\
\hline Stage $2(1 \mathrm{~d})$ & $<0.1$ & $<0.1$ & $<0.5$ & $<0.5$ & $<0.5$ & $<0.5$ \\
\hline Stage 2 (dup) & $<0.1$ & $<0.1$ & $<0.5$ & $<0.5$ & $<0.5$ & $<0.5$ \\
\hline Stage $3(3 d)$ & $<0.1$ & $<0.1$ & $<0.5$ & $<0.5$ & $<0.5$ & $<0.5$ \\
\hline Stage 3 (dup) & $<0.1$ & $<0.1$ & $<0.5$ & $<0.5$ & $(0.16)$ & $<0.5$ \\
\hline Stage $4(1 \mathrm{~d})$ & $<0.1$ & $<0.1$ & $<0.5$ & $<0.5$ & $<0.5$ & $<0.5$ \\
\hline Stage 4 (dup) & $<0.1$ & $<0.1$ & $<0.5$ & $<0.5$ & $<0.5$ & $<0.5$ \\
\hline Stage $5(1 \mathrm{~d})$ & $<0.1$ & $<0.1$ & $<0.5$ & $<0.5$ & $<0.5$ & $<0.5$ \\
\hline Stage 5 (dup) & $<0.1$ & $<0.1$ & $<0.5$ & $(0.38)$ & $<0.5$ & $<0.5$ \\
\hline Stage $6(30 d)$ & $<0.5$ & $<0.5$ & $<0.5$ & $(0.11)$ & $<0.5$ & $<0.5$ \\
\hline Stage 6 (dup) & $<0.5$ & $<0.5$ & $<0.5$ & $<0.5$ & $<0.5$ & $<0.5$ \\
\hline
\end{tabular}

\subsubsection{Chromium}

Chromium was measured at a total concentration of $5,910 \mu \mathrm{g} / \mathrm{g}$ dry wt. in tank C-203 residual waste (Table 2.6; Deutsch et al. 2007c). No crystalline chromium mineral phases were detected by XRD analysis. SEM/EDS analysis indicated that chromium was generally associated with iron oxides. Because of this lack of identification of distinct chromium solid phases, the focus of this discussion is on its leachability from the waste.

Chromium concentrations measured in the C-203 extracts are shown in Table 4.26. Measurable concentrations were found in all the extracts. The highest concentration was measured in a 1-month $\mathrm{CaCO}_{3}$ extract $(13,100 \mu \mathrm{g} / \mathrm{L}$, sample 19961). For all three sequential extractions, Stages 2 through 5 were significantly less than the 1-month single-contact and Stage 1 and 6 extractions. Kinetic rebound effects were again observed for Stage 6 and possibly a minor effect in Stage 3. 
Table 4.26. C-203 Leach Test Results for Chromium (ICP-MS) (concentration units are $\mu \mathrm{g} / \mathrm{L}$ ) (from Deutsch et al. 2007c)

\begin{tabular}{||l|c|c|c|c|c|c||}
\hline \multirow{2}{*}{ Sample Number } & \multicolumn{2}{c|}{ DDI Water } & \multicolumn{2}{c|}{$\mathrm{Ca}(\mathrm{OH})_{2}$} & \multicolumn{3}{c||}{$\mathrm{CaCO}_{3}$} \\
\cline { 2 - 8 } & 19887 & 19961 & 19887 & 19961 & 19887 & 19961 \\
\hline \hline $\mathrm{pH}$ & $9.9-10.7$ & $9.9-10.9$ & $11.6-11.9$ & $11.9-12.9$ & $9.3-10.5$ & $8.0-10.5$ \\
\hline \multicolumn{7}{|c|}{ Single-Contact Tests ${ }^{\text {(a) }}$} \\
\hline 1 month & 5,830 & 11,300 & 3,010 & 10,600 & 11,800 & 11,800 \\
\hline 1 month (dup) & 5,750 & 12,700 & 3,440 & 4,910 & 5,690 & 13,100 \\
\hline Stage 1 (1d) & 11,800 & 14,400 & 1,970 & 2,720 & 4,320 & 9,080 \\
\hline Stage 1 (dup) & 8,910 & 15,600 & 1,760 & 2,850 & 6,550 & 8,780 \\
\hline Stage 2 (1d) & 4,860 & 2,430 & 146 & 221 & 8,120 & 1,690 \\
\hline Stage 2 (dup) & 3,720 & 4,290 & 132 & 247 & 847 & 643 \\
\hline Stage 3 (3d) & 4,240 & 2,310 & 555 & 789 & 994 & 419 \\
\hline Stage 3 (dup) & 3,150 & 2,880 & 330 & 772 & 1,790 & 517 \\
\hline Stage 4 (1d) & 637 & 471 & 172 & 143 & 866 & 107 \\
\hline Stage 4 (dup) & 553 & 431 & 268 & 94.7 & 275 & 87.6 \\
\hline Stage 5 (1d) & 946 & 632 & 74.6 & 86.7 & 558 & 147 \\
\hline Stage 5 (dup) & 991 & 635 & 101 & 140 & 128 & $(35.1)$ \\
\hline Stage 6 (30d) & 4,390 & 2,080 & 1,970 & 2,220 & 5,280 & 1,400 \\
\hline Stage 6 (dup) & 4,000 & 1,670 & 1,500 & 4,090 & 2,600 & 201 \\
\hline $\begin{array}{l}\text { Values in parentheses are less than the EQL. } \\
\text { (a) 1-day single-contact test results are shown in the Stage 1 sequential-contact results. }\end{array}$ \\
EQL = Estimated quantitation limit.
\end{tabular}

Analyses of waste samples by SEM/EDS indicate that chromium in C-202 post-retrieval and C-203 pre-retrieval and post-retrieval samples is generally associated with iron oxides/hydroxides. Because chromium and iron appear to be associated in the waste, chromium/iron ratios in the multiple DDI water extractions for the post-retrieval (residual) samples were calculated and are shown in Table 4.27. The source of the data used for these calculations (ICP-MS values were used for chromium) is provided in Appendix I (Deutsch et al. 2007c). Note that some of the data used for the calculations are qualified values (below the quantitation limit). The molar chromium/iron ratios in the DDI water extracts for the two C-203 samples are remarkably constant ( $1.19 \pm 0.27$ for 19887 and $0.84 \pm 0.16$ for 19961$)$. It is also noteworthy that the average chromium/iron ratios in the DDI water extracts are significantly greater than that ratio in the bulk waste ( 0.44 for 19887 and 0.36 for 19961). The chromium/iron ratios in the DDI water leachates for the C-202 sample (19250) are much more variable $(0.31 \pm 0.41)$; however, the leachates from this waste sample have an average chromium/iron ratio that is much higher than that of the waste itself (0.13), as was the case for the C-203 samples. The elevated chromium/iron ratios in water extracts relative to the waste suggest that chromium is being released through dissolution of iron oxide/hydroxide phases in the waste.

The high chromium concentrations measured in the extracts are significantly greater than that expected to be in equilibrium with freshly precipitated $\mathrm{Cr}(\mathrm{OH})_{3}$ (Rai et al. 1987) and are therefore consistent with chromium in the form of chromate [Cr(VI)] and not $\mathrm{Cr}(\mathrm{III})$. For example, sample 19887 (C-203) single-contact water extracts have chromium concentrations of approximately $2 \times 10^{-5} \mathrm{~mol} / \mathrm{L}$ at $\mathrm{pH}$ values of approximately 10.5 . The total $\mathrm{Cr}$ (III) concentration in equilibrium with freshly precipitated $\mathrm{Cr}(\mathrm{OH})_{3}$ at this $\mathrm{pH}$ is expected to be $<1.4 \times 10^{-7}$ (Rai et al. 1987). This concentration would decrease even further as the crystallinity of the $\mathrm{Cr}(\mathrm{OH})_{3}$ phase increases. 
Table 4.27. Molar Ratios of Chromium/Iron in Multiple Extractions and for C-202 and C-203 Post-Retrieval Waste Samples (from Deutsch et al. 2007c)

\begin{tabular}{|c|c|c|c|c|c|c|c|c|c|c|c|c|c|c|c|c|c|}
\hline Sample & Extract & $1 \mathrm{Mon}$ & $\begin{array}{l}\text { 1Mon } \\
\text { dup }\end{array}$ & Stage 1 & $\begin{array}{c}\text { Stage1 } \\
\text { dup }\end{array}$ & Stage 2 & $\begin{array}{c}\text { Stage2 } \\
\text { dup }\end{array}$ & Stage3 & $\begin{array}{l}\text { Stage3 } \\
\text { dup } \\
\end{array}$ & Stage4 & $\begin{array}{c}\text { Stage4 } \\
\text { dup } \\
\end{array}$ & Stage 5 & $\begin{array}{c}\text { Stage5 } \\
\text { dup }\end{array}$ & Stage6 & $\begin{array}{c}\text { Stage6 } \\
\text { dup }\end{array}$ & Average & $\begin{array}{l}\text { Std. } \\
\text { Dev. }\end{array}$ \\
\hline \multirow{2}{*}{$\begin{array}{c}\mathrm{C}-202 \\
(19250)\end{array}$} & $\mathrm{Ca}(\mathrm{OH}) 2$ & $>15$ & $>13$ & $>2.9$ & $>3.1$ & $>1.7$ & $>1.9$ & $>3.1$ & $>3.2$ & $>2.0$ & $>2.2$ & $>0.7$ & $>0.9$ & $>5.5$ & $>6.1$ & $>4.4$ & $>4.5$ \\
\hline & waste & & & & & & & & & & & & & & & 0.13 & \\
\hline \multirow[t]{2}{*}{$\begin{array}{c}\mathrm{C}-203 \\
(19887)\end{array}$} & $\begin{array}{c}\text { DDI } \\
\text { Water }\end{array}$ & 1.82 & 1.79 & 1.15 & 1.16 & 1.09 & 1.06 & 1.01 & 1.14 & 1.00 & 1.02 & 1.22 & 1.25 & 1.05 & 0.93 & 1.19 & 0.27 \\
\hline & waste & & & & & & & & & & & & & & & 0.44 & \\
\hline \multirow[t]{4}{*}{$\begin{array}{c}\text { C-203 } \\
\text { (19961) }\end{array}$} & $\begin{array}{c}\text { DDI } \\
\text { Water }\end{array}$ & 1.03 & 1.27 & 0.79 & 0.77 & 0.79 & 0.72 & 0.75 & 0.77 & 0.81 & 0.75 & 0.74 & 0.62 & 0.95 & 0.96 & 0.84 & 0.16 \\
\hline & $\mathrm{Ca}(\mathrm{OH}) 2$ & 1.28 & 3.24 & 20.2 & 55.4 & 1.19 & 2.58 & 9.28 & 14.4 & 0.72 & 0.66 & 0.61 & 1.47 & 45.5 & 33.4 & 13.6 & 18.4 \\
\hline & $\mathrm{CaCO} 3$ & 0.94 & 0.85 & 1.12 & 1.06 & 0.81 & 0.82 & 0.83 & 0.76 & 0.45 & 0.32 & 0.61 & 0.32 & 0.87 & 1.04 & 0.77 & 0.26 \\
\hline & waste & & & & & & & & & & & & & & & 0.36 & \\
\hline
\end{tabular}


The concentrations of iron in the $\mathrm{Ca}(\mathrm{OH})_{2}$ extracts are significantly lower than in the DDI water extracts (Appendix I, Deutsch et al. 2007c). The average iron concentration in the C-202 $\mathrm{Ca}(\mathrm{OH})_{2}$ extracts is $<9 \times 10^{-6} \mathrm{~mol} / \mathrm{L}$, while the average for the DDI extracts is $9.1 \times 10^{-6} \pm 9.9 \times 10^{-6} \mathrm{~mol} / \mathrm{L}$. For the C-203 19887 sample, the average iron concentration is $1.6 \times 10^{-6} \pm 0.6 \times 10^{-6} \mathrm{~mol} / \mathrm{L}\left(\mathrm{Ca}(\mathrm{OH})_{2}\right.$ extracts) and $6.8 \times 10^{-5} \pm 5.2 \times 10^{-5} \mathrm{~mol} / \mathrm{L}$ (DDI extracts). For the C-203 19961 sample, the average iron concentrations are $1.5 \times 10^{-5} \pm 4.2 \times 10^{-5} \mathrm{~mol} / \mathrm{L}\left(\mathrm{Ca}(\mathrm{OH})_{2}\right.$ extracts $)$ and $1.1 \times 10^{-4} \pm 1.3 \times 10^{-4} \mathrm{~mol} / \mathrm{L}$ (DDI extracts). For the $\mathrm{Ca}(\mathrm{OH})_{2}$ extracts, the ratios of released chromium/iron are considerably greater, although much more variable than in the DDI water extracts. For the C-202 sample, the average and standard deviation of the chromium/iron ratios are $>4.4 \pm 4.5$, and for the $\mathrm{C}-203$ samples the values are $11.8 \pm 13.7$ (sample 19887) and 13.6 \pm 18.4 (sample 19961). In the case of the C-202 $\mathrm{Ca}(\mathrm{OH})_{2}$ extracts, the iron concentrations were below the detection limit, resulting in chromium/iron ratios that are prefaced with a $>$ sign. Taken as a whole, the $\mathrm{Ca}(\mathrm{OH})_{2}$ extract results are consistent with greater desorption of adsorbed chromate from the surfaces of the iron oxide/hydroxide due to competitive exchange with hydroxide ions and a decrease in anion adsorption (positively charged) sites under the high-pH conditions $(>11.5)$ of the $\mathrm{Ca}(\mathrm{OH})_{2}$ extractions.

Results of the $\mathrm{CaCO}_{3}$ extractions are similar to the DDI water extracts for the three residual waste samples. For the C-202 sample, the average and standard deviation of the chromium/iron ratios are $0.31 \pm 0.37$, and for the C-203 samples the values are $1.49 \pm 0.50$ (sample 19887) and $0.77 \pm 0.26$ (sample 19961). The lower chromium/iron ratios for the $\mathrm{CaCO}_{3}$ extractions compared to the $\mathrm{Ca}(\mathrm{OH})_{2}$ extractions is likely due to the lower $\mathrm{pH}$ conditions (8 to 10.5) of the $\mathrm{CaCO}_{3}$ extractions compared to the $\mathrm{pH}$ values $(>11.5)$ of the $\mathrm{Ca}(\mathrm{OH})_{2}$ extractions. Lower $\mathrm{pH}$ values result in less desorption of chromate from the iron solids because of less competition by hydroxide ions and an increase in anion adsorption sites, or the propensity to convert from $\mathrm{Cr}^{3+}$ hydroxide to chromate under such conditions (see Figure 3.10, upper right-hand side of the stability field).

\subsubsection{Nitrate}

Nitrate was measured at a total concentration of 4,840 $\mu \mathrm{g} / \mathrm{g}$-dry wt in tank C-203 residual waste (Table 2.6; Deutsch et al. 2007c). No crystalline nitrate mineral phases were detected by XRD analysis. SEM/EDS analysis did not indicate the presence of any discrete nitrogen-containing phases. Because of this lack of identification of nitrate solid phases, the focus of this discussion of nitrate is on its leachability from the waste.

Nitrate concentrations measured in the C-203 extracts are shown in Table 4.28. Concentrations as high as $101,000 \mu \mathrm{g} / \mathrm{L}$ were measured (sample 19961 DDI water extract, single-contact 1 month). Concentrations above the detection limit were measured in the 1-month single-contact and Stage 1 extracts for all three extract solutions. Some additional measurements above the detection limit were observed in Stages 2 and 6 for the DDI water extracts and Stage 2 for the $\mathrm{Ca}(\mathrm{OH})_{2}$ extracts. The kinetic rebound effect is observed in Stage 6 of the DDI water extracts. 
Table 4.28. C-203 Leach Test Results for Nitrate (concentration units are $\mu \mathrm{g} / \mathrm{L}$ ) (from Deutsch et al. 2007c)

\begin{tabular}{|c|c|c|c|c|c|c|}
\hline \multirow[b]{2}{*}{ Sample Number } & \multicolumn{2}{|c|}{ DDI Water } & \multicolumn{2}{|c|}{$\mathrm{Ca}(\mathrm{OH})_{2}$} & \multicolumn{2}{|c|}{$\mathrm{CaCO}_{3}$} \\
\hline & 19887 & 19961 & 19887 & 19961 & 19887 & 19961 \\
\hline$\overline{\mathrm{pH}}$ & $9.9-10.7$ & $9.9-10.9$ & $11.6-11.9$ & $11.9-12.9$ & $9.3-10.5$ & $8.0-10.5$ \\
\hline \multicolumn{7}{|c|}{ Single-Contact Tests $^{(\mathrm{a})}$} \\
\hline 1 month & 41,600 & 77,700 & 42,300 & 64,300 & 51,600 & 58,000 \\
\hline 1 month (dup) & 46,000 & 101,000 & 49,200 & 48,300 & 59,400 & 57,000 \\
\hline \multicolumn{7}{|c|}{ Sequential-Contact Tests } \\
\hline Stage 1 (1d) & 56,600 & 65,900 & 46,300 & 54,500 & 53,200 & 54,500 \\
\hline Stage 1 (dup) & 49,300 & 74,400 & 37,200 & $<4,330$ & 43,500 & 55,700 \\
\hline Stage 2 (1d) & 1,600 & 1,070 & $<4,330$ & 57,700 & $<4,330$ & $<4,330$ \\
\hline Stage 2 (dup) & 539 & 745 & $<4,330$ & $<4,330$ & $<4,330$ & $<4,330$ \\
\hline Stage 3 (3d) & $<433$ & $<433$ & $<4,330$ & $<4,330$ & $<4,330$ & $<4,330$ \\
\hline Stage 3 (dup) & $<433$ & $<433$ & $<4,330$ & $<4,330$ & $<4,330$ & $<4,330$ \\
\hline Stage 4 (1d) & $<433$ & $<433$ & $<4,330$ & $<4,330$ & $<4,330$ & $<4,330$ \\
\hline Stage 4 (dup) & $<433$ & $<433$ & $<4,330$ & $<4,330$ & $<4,330$ & $<4,330$ \\
\hline Stage 5 (1d) & $<433$ & $<433$ & $<4,330$ & $<4,330$ & $<4,330$ & $<4,330$ \\
\hline Stage 5 (dup) & $<433$ & $<433$ & $<4,330$ & $<4,330$ & $<4,330$ & $<4,330$ \\
\hline Stage $6(30 d)$ & 1,090 & 1,220 & $<4,330$ & $<4,330$ & $<4,330$ & $<4,330$ \\
\hline Stage 6 (dup) & 916 & 1,100 & $<4,330$ & $<4,330$ & $<4,330$ & $<4,330$ \\
\hline
\end{tabular}

\subsubsection{Percentage Leachable Contaminants of Interest}

Percentages of the most important contaminants of interest (technetium-99 and uranium-238) released during the 1-month single-contact and sequential-contact leaching tests from tank C-203 residual waste relative to fusion results are shown in Table 4.29. The percentages of technetium-99 that were leachable were very low. Most values were below the detection limit. A few values in the 1-month single-contact and Stage 1 of the periodic replenishment tests detectable but below the EQL. The percentages of leachable uranium-238 were fairly low. The 1-month single contact, Stage 1, and Stage 6 typically had the highest percentages of leachable uranium-238 for all leachant solutions.

Table 4.29. Percentages of Technetium-99 and Uranium-238 Released During Leaching Tests from Tank C-203 Residual Waste Relative to Fusion Results (from Deutsch et al. 2007c)

\begin{tabular}{||l|c|c||}
\hline \multirow{2}{*}{\multicolumn{1}{||}{ Leachate }} & Technetium-99 & Uranium-238 \\
\cline { 2 - 3 } & \multicolumn{2}{c||}{ (\% Leachable) } \\
\hline \hline \multicolumn{3}{|c|}{ 1-Month Single-Contact } \\
\hline $\mathrm{C}-106 \mathrm{Water}$ Leach Range & BDL & 2.5 to 2.6 \\
\hline $\mathrm{C}-106 \mathrm{Ca}(\mathrm{OH})_{2}$ Range & BDL & 0.03 to 2.4 \\
\hline $\mathrm{C}-106 \mathrm{CaCO}$ Range & BDL to (31) & 4.4 to 8.7 \\
\hline \multicolumn{3}{|c||}{ Stage 1 } \\
\hline $\mathrm{C}-106 \mathrm{Water}$ Leach & (1.5) to $(10.4)$ & 5.7 to 10.3 \\
\hline $\mathrm{C}-106 \mathrm{Ca}(\mathrm{OH})_{2}$ & BDL to $(26.2)$ & 0.063 to 0.080 \\
\hline $\mathrm{C}-106 \mathrm{CaCO}$ & BDL & 2.0 to 3.7 \\
\hline \hline
\end{tabular}


Table 4.29. (contd)

\begin{tabular}{|c|c|c|}
\hline \multirow[b]{2}{*}{ Leachate } & Technetium-99 & Uranium-238 \\
\hline & \multicolumn{2}{|c|}{ (\% Leachable) } \\
\hline \multicolumn{3}{|c|}{$\begin{array}{l}\text { Stage } 2 \\
\end{array}$} \\
\hline C-106 Water Leach & $\mathrm{BDL}$ & 1.8 to 2.1 \\
\hline $\mathrm{C}-106 \mathrm{Ca}(\mathrm{OH})_{2}$ & BDL & 0.015 to 0.039 \\
\hline $\mathrm{C}-106 \mathrm{CaCO}_{3}$ & BDL & 1.0 to 1.2 \\
\hline \multicolumn{3}{|c|}{ Stage 3} \\
\hline C-106 Water Leach & BDL & 1.8 to 2.2 \\
\hline $\mathrm{C}-106 \mathrm{Ca}(\mathrm{OH})_{2}$ & $\mathrm{BDL}$ & 0.0039 to 0.012 \\
\hline $\mathrm{C}-106 \mathrm{CaCO}_{3}$ & BDL & 0.5 to 0.8 \\
\hline \multicolumn{3}{|c|}{ Stage 4} \\
\hline C-106 Water Leach & BDL & 0.4 to 0.5 \\
\hline $\mathrm{C}-106 \mathrm{Ca}(\mathrm{OH})_{2}$ & $\mathrm{BDL}$ & 0.0020 to 0.0024 \\
\hline $\mathrm{C}-106 \mathrm{CaCO}_{3}$ & $\mathrm{BDL}$ & 0.2 to 0.4 \\
\hline \multicolumn{3}{|c|}{ Stage 5} \\
\hline C-106 Water Leach & $\mathrm{BDL}$ & 0.5 to 0.6 \\
\hline $\mathrm{C}-106 \mathrm{Ca}(\mathrm{OH})_{2}$ & BDL & 0.0009 to 0.0010 \\
\hline $\mathrm{C}-106 \mathrm{CaCO}_{3}$ & $\mathrm{BDL}$ & 0.3 \\
\hline \multicolumn{3}{|c|}{ Stage 6} \\
\hline C-106 Water Leach & $\mathrm{BDL}$ & 2.8 to 6.4 \\
\hline $\mathrm{C}-106 \mathrm{Ca}(\mathrm{OH})_{2}$ & $\mathrm{BDL}$ & 0.0004 to 0.0005 \\
\hline $\mathrm{C}-106 \mathrm{CaCO}_{3}$ & $\mathrm{BDL}$ & 1.7 to 2.7 \\
\hline
\end{tabular}

\subsection{Contaminants of Interest in Residual Waste Saltcake}

At this time, no residual waste from a retrieved saltcake tank has been characterized. Although the TWINS/BBI database does have characterization data for pre-retrieval waste from saltcake tanks, the composition of the post-retrieval residuals is likely to be very different from the pre-retrieval waste. For example, it is believed that during the retrieval of saltcake tank S-112, $99.6 \%$ to $99.8 \%$ of the tank waste was removed. The primary methods for retrieving saltcake waste from the tank involved the use of highpressure water to remove the waste. As a result, it is likely that the residual waste in the saltcake tanks may have characteristics that are similar to those of waste tanks; that is, phases that are very recalcitrant to dissolution by aqueous solutions, with most of the soluble contaminants being removed during the retrieval process. As a result, contaminant release from saltcake tank residuals cannot be evaluated at this time but qualitatively is likely similar to the residual wastes from sludge tanks described in this document. 


\subsection{Contaminant Release Mechanisms and Development of Release Models}

\subsection{Release Mechanisms}

The release of contaminants from residual tank waste can occur through a variety of mechanisms, including mineral dissolution, desorption, and diffusion. It is possible that two or all three of these mechanisms can contribute to the release of contaminants from residual waste simultaneously. In the case of dissolution and desorption, reaction rates can potentially influence release concentrations.

\subsubsection{Mineral Dissolution}

The solubility of a substance in a specific solvent at a specific temperature is defined as the maximum amount of the solute that will dissolve in a definite amount of the solvent and produce a stable system. Determining the equilibrium solubility of a particular contaminant requires knowledge of the specific solid phase in which the contaminant exists, chemical composition of the aqueous solution in contact with the solid phase, and a variety of thermodynamic data, including the solubility constant of the compound of interest and stability constants for various aqueous complexes that could potentially form with the contaminant and other components of the system. If all the necessary thermodynamic data and system composition data are available, the equilibrium solubility of the contaminant can be calculated using various geochemical reaction computer codes available for this purpose. Published critical reviews and tabulations of thermodynamic constants completed by the Nuclear Energy Agency of the Organization for Economic Cooperation and Development in Palaiseau, France (with multinational funding) are valuable resources for thermodynamic constants required to calculate solubility for most radionuclides of interest related to high-level-waste. Compilations are available for the thermodynamic constants for aqueous, solid, and gaseous species containing uranium (Grenthe et al. 1992) and technetium (Rard et al. 1999). Although the thermodynamic equilibrium approach is generally the most reliable method available for determining solubility, a number of factors can lead to results that are not consistent with measured values. These can include non-equilibrium conditions, incorrect thermodynamic data, or lack of all necessary thermodynamic data. When the controlling solid cannot be identified but empirical solubility tests clearly indicate that some unidentified phase is controlling solution concentration, an empirical solubility relationship can be used. The weakness of this approach is that changing conditions can significantly alter solubility.

Contaminants of interest can occur as a primary component of a mineral phase or as a trace component of a mineral phase in which other elements make up the primary components of the phase. In either case, the release of the COI will be controlled in large part by the dissolution rate of the phase containing the COI. When the COI is a primary component of its host phase in the residual waste, the COI solution concentration can have a direct impact on the dissolution of the phase and, as a result, further release of contaminant from that solid phase. In the case in which the COI is a trace constituent in a co-precipitated phase, the solution concentration of the contaminant typically will not significantly influence dissolution of the solid phase containing the contaminant. 


\subsubsection{Desorption}

Adsorption of contaminants of interest onto the surfaces of waste components may have occurred in the past when tanks sludge was in contact with tank supernatant solutions containing contaminants. Desorption of contaminants adsorbed to post-retrieval waste could occur in the future after contacting infiltration water. It is possible that any contaminants that were previously adsorbed to sludge may be significantly reduced during tank retrieval processes by desorption processes if wet sluicing is used.

\subsubsection{Diffusion}

Diffusion is a transport mechanism that may affect contaminant release after tank closure. After tank closure, the residual waste may act similarly to a thin layer of clay sandwiched between the bottom of the tank and the overlying tank filler. As the tank components disintegrate over time and infiltration begins to contact the waste, contaminants that are dissolved within the pore fluids of the residual waste will begin to diffuse toward and into infiltration water coming into contact with the waste and tank components. If the hydrologic regime allows for fluid advection, dissolved contaminants will migrate even faster than diffusion-controlled processes.

\subsection{Geochemical Conditions Affecting Release}

A wide range of geochemical conditions or parameters can affect the release of contaminants from residual waste. These include $\mathrm{pH}, \mathrm{Eh}$, ionic strength, major ion concentrations, complexing agents (both inorganic and organic), and temperature. How each of these conditions or parameters can influence contaminant release from residual waste is addressed in this section.

One of the primary geochemical parameters to influence the release of contaminants from residual waste is $\mathrm{pH}\left(-\log \left\{\mathrm{H}^{+}\right\}\right.$, the negative logarithm of hydrogen ion activity). The influence of $\mathrm{pH}$ on contaminant release occurs through many aspects of geochemistry. The solubility of most mineral phases is a function of $\mathrm{pH}$. Complexing agents are typically anions. When theses anions become protonated, they are no longer available to complex metals. The degree of protonation of anions is a function of $\mathrm{pH}$. Adsorption and ion exchange also are affected by $\mathrm{pH}$. At lower $\mathrm{pH}$, sorption surfaces become more positively charged, favoring anion adsorption; at high $\mathrm{pH}$, surfaces become more negatively charged, favoring cation adsorption. At low $\mathrm{pH}$ values, protons can compete with other cations for adsorption to surface cation exchange sites.

Eh or pe (-log $\left\{\mathrm{e}^{-}\right\}$, the negative logarithm of electron activity) is another primary geochemical parameter that can have a large impact on contaminant release from residual waste. Eh controls the equilibrium oxidation state of redox-sensitive elements and, as a result, can have a dramatic influence on its solubility and other geochemical reactions. Although changes in Eh can significantly influence the geochemistry of a specific system, the natural Hanford vadose zone is generally oxidizing. Reducing conditions can occur at locations where organic wastes have been disposed as well as in micro environments affected by ferrous iron-containing minerals such as biotite and certain minerals in basalt clasts such as pyroxene and olivine.

Ionic strength can influence the geochemistry of contaminant release by affecting activity coefficients of dissolved constituents. This effect is much greater for highly charged species than for lesser charged species. Although the impact of high ionic strength supernatant solutions on contaminant release could be 
significant, this potential impact after tank retrieval is likely to have been largely removed. The same goes for the impact of high major ion concentrations in supernatant solutions.

Important complexing agents for COIs include certain inorganic anions such as $\mathrm{CO}_{3}{ }^{2-}$ and $\mathrm{OH}^{-}$, as well as certain organic complexants such as EDTA and HEDTA. As indicated earlier, complexing agents can have a significant impact on the solubility of certain contaminants. For example, U(VI) can form strong complexes with $\mathrm{CO}_{3}{ }^{2-}$ and $\mathrm{OH}^{-}$. The concentrations of these two complexing agents are very high in most tank wastes and high in Hanford groundwater and vadose zone pore water. Although high concentrations of organic complexants are known to occur in certain tank wastes, it is likely that the majority of this waste will be removed during retrieval (see also Section 3.2.2 for a discussion of organic complexants in the SSTs).

High temperatures have occurred in Hanford waste tanks in the past because of the very high concentrations of radionuclides in the tank waste that release heat from radioactive decay. Temperatures as high as $120^{\circ} \mathrm{C}$ inside and outside the tanks have been recorded in the past. Because the radiation field has decreased over the decades since the waste was first placed in the tanks and most of the tank waste will be removed prior to closure, high temperatures are not expected to be a significant factor in contaminant release from post-retrieval waste subsequent to closure.

\subsection{Release Models}

Contaminant release models have been developed for retrieved tanks C-103, C-106, C-202, and C-203 by the PNNL Residual Tank Waste Contaminant Release Project, to estimate the fate and transport of contaminants from residual waste subsequent to tank closure. Release models will be developed in the future for additional tanks as sludge and saltcake wastes are retrieved and residual waste samples become available for characterization. The ultimate goal is to provide enough characterization data from a representative set of SSTs to establish the variability of release model parameters that could be expected without having to conduct complete characterization studies for all 149 SSTs. Once enough characterization data are available, it may be possible to develop a correlation between release parameters and a minimal set of characterization data, such as total elemental analysis of the residual waste complemented by solid phase characterization (e.g., XRD and SEM/EDS).

The release models that have been developed are based on geochemical characterization studies to establish total concentrations of contaminants of interest in the waste, the percentage of the contaminants of interest in the waste that are water-leachable, and the dissolved release concentrations of contaminants of interest that will leach from the waste using simple end member solutions. This information will be combined with a flow and transport code to establish the future migration of contaminants from the closed tanks, through the vadose zone into groundwater, and through the groundwater to potential receptors. Codes that are currently being considered for these performance assessment calculations are STOMP (White and Oostrom 2003) and STORM (Bacon et al. 2004). The performance assessment code will include all important hydrogeologic factors regarding the closed tank system. These factors will include the steel liner of the tank, the concrete shell, tank filler, soil or gravel cover, cap, and infiltration rates.

Two different closure scenarios have been considered in the development of the release models. In Scenario 1, the tank is filled with a relatively inert material such as Hanford formation sand or gravel that does not significantly affect the chemistry of infiltrating water, which, in turn, contacts the residual waste. 
For this scenario, it is assumed that the water contacting the waste is similar to a typical Hanford groundwater. Site groundwater is generally in equilibrium with calcite and has a $\mathrm{pH}$ near 8.2 and a low ionic strength $(\mathrm{I}<0.01 \mathrm{M})$.

In Scenario 2, the tank is filled with a cementitious grout. Cements have a complex pore fluid chemistry that evolves over time (Atkins and Glasser 1992; Reardon 1992; IAEA 1993; others). For fresh cement, pore fluids have a high $\mathrm{pH}$ as a result of unreacted portlandite $\left[\mathrm{Ca}(\mathrm{OH})_{2}\right]$ in the cement and high ionic strength from dissolved salts that remain in the pores of the cement after it sets up. As the cement ages through contact with infiltrating water, salts in the pore fluids will be diluted, and $\mathrm{CO}_{2}$ dissolved in infiltrating water will react with the portlandite to form calcite $\left(\mathrm{CaCO}_{3}\right)$. As this process comes to completion, the pore fluids in the aged cement will come to resemble that of Hanford groundwater. As a result of these processes, Scenario 2 has been divided into two stages. Stage 1 of Scenario 2 is the fresh cement scenario, which was simulated in the laboratory by leaching the residual waste with a $0.01 \mathrm{M}$ $\mathrm{Ca}(\mathrm{OH})_{2}$ solution. Stage 2 of Scenario 2 is the aged cement scenario, which was simulated by leaching a fresh sample of waste with a $\mathrm{Ca}\left(\mathrm{CO}_{3}\right)$-saturated solution. Stage 2 of Scenario 2 is considered to be identical to Scenario 1. These scenarios ignore any impact of silica release that could potentially leach from the cementitious grout. This could potentially result in an overestimate of release concentrations for uranium due to precipitation of a uranyl silicate phase that would lower the release concentrations of uranium.

Characterization studies conducted for developing release models are designed with the aim of developing mechanistic contaminant release models. Mechanistic release models rely on an understanding of the fundamental geochemical processes governing the release of contaminants of interest from the residual waste. For example, if a specific phase is controlling the release of a contaminant, it would be necessary to know what that phase is, its thermodynamic solubility constant and other relevant thermodynamic data, and the concentration of the controlling phase in the residual waste. It would also be necessary to know if the solid phase comes to equilibrium with water quickly, relative to the rate of infiltration. If the approach to equilibrium is slow, determination of dissolution rate constants would be required. Other mechanistic data that could be necessary include rates of redox reactions, equilibrium surface adsorption/desorption constants, and diffusion coefficients. Mechanistic release models are preferred over empirical release models because mechanistic models are more scientifically justifiable and do not have to be as conservative as empirical models, which in general have greater uncertainty.

In some cases, it is not possible to establish a mechanistic release model. For example, it may not be possible to identify the solubility-controlling phases for every $\mathrm{COI}$ in the residual waste. This may be because the phases do not reach equilibrium in a time frame that is practical for laboratory analysis. In other cases, it may be very difficult to identify the solubility-controlling phases because the phases are amorphous (cannot be identified by XRD) and/or the COIs are present at concentrations in the waste too miniscule to be detected by solid phase characterization tools currently available. In addition, the waste particles often appear to be composites of numerous phases, further complicating phase identification.

In the case of pre-retrieval tank waste from C-203 and C-204 (Deutsch et al. 2007b), a combination of mechanistic and empirical release model was developed. However, for the four post-retrieval tank wastes that have been characterized so far, only empirical release models could be developed. 


\subsection{Contaminant Release Data for Residual Waste in Retrieved Tanks}

Two tank scenarios have been considered by the PNNL Residual Tank Waste Contaminant Release Project as part of the development of the contaminant release models for retrieved tanks. In the first scenario, it is assumed that the tanks are filled with a relatively inert material such as quartz sand or crushed basalt that does not significantly affect the chemistry of infiltration water that will contact the post-retrieval waste. In this case, the composition of water contacting the post-retrieval waste is assumed to be controlled largely by the solubility of calcite $\left(\mathrm{CaCO}_{3}\right)$. Calcite is a ubiquitous component of most Hanford vadose zone sediments, and future infiltrating water likely will equilibrate with this relatively soluble, reactive mineral.

In the second tank scenario, it is assumed that the tanks are filled with a cementitious grout. Hydration products (calcium silicate hydrogel $[\mathrm{CSH}]$ and portlandite $\left[\mathrm{Ca}(\mathrm{OH})_{2}\right]$ ) of the highly reactive clinker solids [such as tricalcium silicate (alite), dicalcium silicate (belite), tricalcium aluminate $\left(3 \mathrm{CaO} \cdot \mathrm{Al}_{2} \mathrm{O}_{3}\right)$, and calcium aluminoferrite $\left(2 \mathrm{CaO} .(\mathrm{Al}, \mathrm{Fe})_{2} \mathrm{O}_{3}\right]$ in the dry cement blends dominate the pore fluid-chemistry and its evolution. It is assumed that once the grout sets up, some portion of its hydration product, the $\mathrm{Ca}(\mathrm{OH})_{2}$, will remain unreacted in the grout, and it will control the $\mathrm{pH}$ of the system. During this fresh grout time frame, the $\mathrm{pH}$ of the leaching solution generated by the grout is expected to be approximately 12.4 .

As dissolved $\mathrm{CO}_{2}$ in water or present in the air contacts the grout, $\mathrm{Ca}(\mathrm{OH})_{2}$ will react to form calcite. At some point in time, calcite will control the pore water concentration and the grout will be considered aged. At that time, the characteristics of the leaching solution generated by water contacting grout will be controlled largely by the solubility of calcite and the partial pressure of $\mathrm{CO}_{2}$ gas in the system. If the $\mathrm{CO}_{2}$ partial pressure is the same as that in the atmosphere, the $\mathrm{pH}$ of the solution will be approximately 8.3. This second stage of Scenario 2 is assumed to be identical to that of Scenario 1.

\subsection{Contaminant Release Model for Tank C-103}

An empirical solubility release model was developed to describe contaminant release for residual sludges in tank $\mathrm{C}-103 . \mathrm{CaCO}_{3}$ extract compositions are expected to provide the most representative release concentrations of contaminants for the first scenario in which the pore water is in equilibrium with calcite. Portlandite extract compositions are expected to provide the most representative release concentrations of contaminants for the first phase of the second scenario (fresh cement), and the $\mathrm{CaCO}_{3}$ extract compositions are expected to provide the most representative release concentrations of contaminants for the second phase of the second scenario (aged cement/grout in which the $\mathrm{Ca}(\mathrm{OH})_{2}$ has been converted to $\mathrm{CaCO}_{3}$ ).

Three C-103 residual waste samples were analyzed. The highest contaminant concentrations measured in the respective leachates and residual waste of the three samples were used to represent the empirical release model concentrations. These values are provided in Table 6.1. Scenario 1 and Phase 2 of scenario 2 are indicated as calcite. Phase 1 of scenario 2 is indicated as fresh cement $\left[\mathrm{Ca}(\mathrm{OH})_{2}\right]$. The contaminant concentrations in the C-103 residual waste determined for the model are 4,200 $\mu \mathrm{g}$ uranium-238/g residual waste, $230 \mu \mathrm{g}$ chromium/g residual waste, and $0.28 \mu \mathrm{g}$ technetium-99/g residual 
waste. The release concentrations of uranium-238 are 4,100 $\mu \mathrm{g} / \mathrm{L}$ for the calcite scenario and $2.0 \mu \mathrm{g} / \mathrm{L}$ for the fresh cement scenario. Chromium release concentrations are similar for both scenarios at $18 \mu \mathrm{g} / \mathrm{L}$ for the calcite scenario and $19 \mu \mathrm{g} / \mathrm{L}$ for the fresh cement scenario. Release concentrations for technetium-99 are also similar for both scenarios, at $0.16 \mu \mathrm{g} / \mathrm{L}$ for the calcite scenario and $0.19 \mu \mathrm{g} / \mathrm{L}$ for the fresh cement scenario.

Table 6.1. Maximum C-103 Residual Waste and Contaminant Release Concentrations for Release Model

\begin{tabular}{||l|c|c|c||}
\hline \hline \multicolumn{1}{|c|}{ Release Scenario } & Component & $\begin{array}{c}\text { Sludge Conc. } \\
\mu \mathrm{g} / \mathrm{g} \text { Sludge }\end{array}$ & $\begin{array}{c}\text { Max. Release } \\
\text { Conc. } \mu \mathrm{g} / \mathrm{L}\end{array}$ \\
\hline \hline Calcite $\left[\mathrm{CaCO}_{3}\right]$ & ${ }^{238} \mathrm{U}$ & 4,200 & 4,100 \\
\hline Fresh cement $\left[\mathrm{Ca}(\mathrm{OH})_{2}\right]$ & ${ }^{238} \mathrm{U}$ & 4,200 & 2.0 \\
\hline Calcite $\left[\mathrm{CaCO}_{3}\right]$ & $\mathrm{Cr}$ & 230 & 18 \\
\hline Fresh cement $\left[\mathrm{Ca}(\mathrm{OH})_{2}\right]$ & $\mathrm{Cr}$ & 230 & 19 \\
\hline Calcite $\left[\mathrm{CaCO} \mathrm{C}_{3}\right]$ & ${ }^{99} \mathrm{Tc}$ & 0.28 & 0.16 \\
\hline Fresh cement $\left[\mathrm{Ca}(\mathrm{OH})_{2}\right]$ & ${ }^{99} \mathrm{Tc}$ & 0.28 & 0.19 \\
\hline
\end{tabular}

\subsection{Contaminant Release Model for Tank C-106}

Because of the highly complex chemical nature of the residual waste in tank C-106, clear and quantitative phase associations of the COIs with the phases known to exist in the residual waste are difficult to specify. Although the various characterization methods employed in this study have revealed a number of important observations and have provided valuable data for constructing a scientifically defensible release model, many questions remain. Because a thorough understanding of all the important phase associations for the contaminants of interest cannot be developed at this time, an empirically based release model has been developed. Although less satisfying from a mechanistic point of view, the empirical release model that can be used now and is conservative in nature. Later work may provide a better understanding of the phase associations with the contaminants of interest and the release mechanisms from these phases. In this case, a less conservative but more scientifically defensible release model could be developed.

Maximum release rates for technetium-99, uranium-238, and chromium from C-106 residual waste extracts using $\mathrm{CaCO}_{3}$ (Scenario 1 and Phase 2 of Scenario 2, aged cement simulant) and $\mathrm{Ca}(\mathrm{OH})_{2}$ (Scenario 2, fresh cement simulant) were determined from the 1-month leachates. This was done because the concentrations measured in these leachates were generally higher than those measured in the shortterm sequential leach extracts. Because it is necessary to rely on empirical release data for the release model, this more conservative approach is preferred. In addition, a longer leaching period is more representative of actual water/waste contact times expected in the future closed tank.

Table 6.2 is a summary of the contaminant release model data for tank C-106 for Scenario 1 and Phase 2 of Scenario 2 (aged cement, $\mathrm{CaCO}_{3}$-equilibrium). Iodine-129 and chromium were not measured above their respective detection limits; therefore, the detection limit values were used for the empirical release concentrations. 
Table 6.2. Summary of Contaminant Release Model Data for Tank C-106, Scenario 1 and Phase 2 of Scenario 2 (aged cement, $\mathrm{CaCO}_{3}$-equilibrium) (from Deutsch et al. 2006)

\begin{tabular}{||c|c|c|c||}
\hline \hline Contaminant & Waste Concentration & Release Concentration & Release Control \\
\hline \hline${ }^{99} \mathrm{Tc}$ & $\begin{array}{c}1.2 \mu \mathrm{g}{ }^{99} \mathrm{Tc} / \mathrm{g} \text {-waste } \\
\left(20,000 \mathrm{pCi}{ }^{99} \mathrm{Tc} / \mathrm{g} \text {-waste }\right)\end{array}$ & $\begin{array}{c}0.39 \mu \mathrm{g} / \mathrm{L} \\
(6,600 \mathrm{pCi} / \mathrm{L})\end{array}$ & Solubility \\
\hline${ }^{238} \mathrm{U}$ & $310 \mu \mathrm{g}{ }^{238} \mathrm{U} / \mathrm{g}$-waste & $49 \mu \mathrm{g} / \mathrm{L}$ & Solubility \\
\hline${ }^{129} \mathrm{I}$ & $0.62 \mu \mathrm{g}{ }^{129} \mathrm{I} / \mathrm{g}$-waste & $0.35 \mu \mathrm{g} / \mathrm{L}$ & Solubility \\
& $\left(110 \mathrm{pCi}{ }^{129} \mathrm{I} / \mathrm{g}\right.$-waste $)$ & $(61 \mathrm{pCi} / \mathrm{L})$ & Solubility \\
\hline $\mathrm{Cr}$ & $897 \mu \mathrm{g} \mathrm{Cr} / \mathrm{g}$-waste & $<283 \mu \mathrm{g} / \mathrm{L}$ & \multicolumn{2}{|l}{} \\
\hline
\end{tabular}

Table 6.3 is a summary of the contaminant release model data for tank C-106 for scenario 2 (fresh cement, $\left.0.01 \mathrm{M} \mathrm{Ca}(\mathrm{OH})_{2}\right)$. For iodine- 129 and chromium, measured concentrations in the leachates were below the detection limits; therefore, the detection limit values were used for the release concentration. Total waste concentrations are provided in column 3 of Table 6.3. These values were determined, as indicated in Deutsch et al. (2006) from either the fusion method or EPA Method 3050B (Acid Digestion of Sediments), whichever had the highest concentration.

Table 6.3. Summary of Contaminant Release Model Data for Tank C-106, Fresh Cement [0.01 M $\mathrm{Ca}(\mathrm{OH})_{2}$ ] Scenario (from Deutsch et al. 2006)

\begin{tabular}{||c|c|c|c||}
\hline \hline Contaminant & Waste Concentration & Release Concentration & Release Control \\
\hline \hline${ }^{99} \mathrm{Tc}$ & $\begin{array}{c}1.2 \mu \mathrm{g}{ }^{99} \mathrm{Tc} / \mathrm{g} \text {-waste } \\
\left(20,000 \mathrm{pCi}{ }^{99} \mathrm{Tc} / \mathrm{g} \text {-waste }\right)\end{array}$ & $\begin{array}{c}1.2 \mu \mathrm{g} / \mathrm{L} \\
(20,000 \mathrm{pCi} / \mathrm{L})\end{array}$ & Solubility \\
\hline${ }^{238} \mathrm{U}$ & $310 \mu \mathrm{g}{ }^{238} \mathrm{U} / \mathrm{g}$-waste & $36 \mu \mathrm{g} / \mathrm{L}$ & Solubility \\
\hline${ }^{129} \mathrm{I}$ & $0.62 \mu \mathrm{g}{ }^{129} \mathrm{I} / \mathrm{g}$-waste & $0.17 \mu \mathrm{g} / \mathrm{L}$ & Solubility \\
& $\left(110 \mathrm{pCi}{ }^{129} \mathrm{I} / \mathrm{g}\right.$-waste $)$ & $(30 \mathrm{pCi} / \mathrm{L})$ & Solubility \\
\hline $\mathrm{Cr}$ & $897 \mu \mathrm{g} \mathrm{Cr} / \mathrm{g}$-waste & $<470 \mu \mathrm{g} / \mathrm{L}$ & \multicolumn{1}{|l}{} \\
\hline
\end{tabular}

\subsection{Contaminant Release Model for Tanks C-202 and C-203}

Because of the high concentrations of uranium in C-202 and C-203 residual waste and its relatively high leachability from these residual wastes, uranium is expected to be an important risk driver for these tanks. The SI calculation results, TIC measurements, and XRD results for the samples suggest that the dominant form of uranium in C-202 and C-203 residual waste could be $\mathrm{Na}_{2} \mathrm{U}_{2} \mathrm{O}_{7}(\mathrm{am})$. However, the SI calculations and testing of the waste did not identify a specific phase that controlled the release of uranium, or of any of the other primary contaminants of interest, in the $\mathrm{CaCO}_{3}$ or $\mathrm{Ca}(\mathrm{OH})_{2}$ extracts, which are our simplified end member infiltrating waters for aged and fresh grout, respectively.

Because testing of the residual waste did not identify mineral equilibrium as a control on contaminant release, a mechanistic release model for the C-202 and C-203 residual wastes could not be developed. In place of a mechanistic model, an empirical solubility release model was selected as the most appropriate method to describe contaminant release for residual wastes in tanks C-202 and C-203. Calcium carbonate extract compositions are expected to provide the most representative release concentrations of contaminants for the first scenario in which the pore water is in equilibrium with calcite. Calcium hydroxide extract compositions are expected to provide the most representative release concentrations of contaminants for the first phase of the second scenario (fresh cement), and the $\mathrm{CaCO}_{3}$ extract compositions are expected to provide the most representative release concentrations of contaminants for the second phase 
of the second scenario (aged cement/grout, in which the $\mathrm{Ca}(\mathrm{OH})_{2}$ and $\mathrm{CSH}$ phases have been converted to $\mathrm{CaCO}_{3}$ ). The empirical solubility approach is likely to provide the most accurate estimates for the nearterm period. It is expected that for longer periods, this method is conservative in that it will significantly overestimate concentrations of released contaminants. The solubility approach is supported by the results of the sequential extracts, which generally demonstrate that contaminant concentrations leached from the residual waste drop off significantly with increasing contact number. In most cases, concentrations for measurable contaminants decreased by at least a factor of 10 between Stage 1 and Stage 5. A concentration rebound was sometimes observed in Stage 6, which had a 1-month contact time (compared to 1 or 3 days for Stages 1 to 5).

The maximum dissolved concentrations measured in the multiple extraction experiments and total concentrations present in the residual waste for the contaminants of interest (uranium, chromium, technetium-99, and iodine-129) for the $\mathrm{Ca}(\mathrm{OH})_{2}$ and $\mathrm{CaCO}_{3}$ extracts are the values used for the empirical release model. These data are shown in Table 6.3. The maximum values measured in each extraction experiment usually occurred in Stage 1 (1-day contact) or the 1-month single-contact extraction, but in some cases, the maximum concentration occurred in Stage 6 (30-day contact) of the sequential leach tests. Chemical composition data for all the extraction experiments are tabulated in Deutsch et al. (2007c, Appendix I). Total waste concentrations shown in Table 6.3 were determined from either fusion or acid digestion, whichever produced the highest result (Deutsch et al. 2007c), and Section 2.2.2 in this data package contains the results of the waste composition measurements.

The data in Table 6.4 for Scenario 1 and Phase 2 of Scenario 2 are indicated as calcite $\left[\mathrm{CaCO}_{3}\right]$. Phase 1 of Scenario 2 is indicated as fresh cement $\left[\mathrm{Ca}(\mathrm{OH})_{2}\right]$. The uranium concentration in the C-202 waste $\left(2.4 \times 10^{5} \mu \mathrm{g} / \mathrm{g}\right.$ waste, $\left.24 \mathrm{wt} \%\right)$ is about one-half that of the C-203 waste $\left(5.9 \times 10^{5} \mu \mathrm{g} / \mathrm{g}\right.$ waste, $59 \mathrm{wt} \%)$. It is also noteworthy that the calcite stage for both tanks has uranium release concentrations that are greater by factors of $36(\mathrm{C}-202)$ and 1.7 (C-203) than those of the fresh cement phase. For tank $\mathrm{C}-202$, the maximum uranium release concentration $\left(6.1 \times 10^{4} \mu \mathrm{g} / \mathrm{L}\right)$ is nearly 10 times less than that for $\mathrm{C}-203\left(5.1 \times 10^{5} \mu \mathrm{g} / \mathrm{L}\right)$. The maximum uranium release concentration for the $\mathrm{C}-202$ residual waste during the fresh cement phase $\left(1.7 \times 10^{3} \mu \mathrm{g} / \mathrm{L}\right)$ is more than 100 times less than that from the $\mathrm{C}-203$ residual waste $\left(3.0 \times 10^{5} \mu \mathrm{g} / \mathrm{L}\right)$ during this phase.

The chromium concentration in the C-202 residual waste $\left(1.0 \times 10^{4} \mu \mathrm{g} / \mathrm{g}\right.$ waste, $\left.1 \mathrm{wt} \%\right)$ is more than double that of the C-203 residual waste $\left(4.3 \times 10^{3} \mu \mathrm{g} / \mathrm{g}\right.$ waste, $\left.0.43 \mathrm{wt} \%\right)$. For tank C-202 residual waste, chromium release concentrations $\left(2.0 \times 10^{3} \mu \mathrm{g} / \mathrm{L}\right)$ for the calcite stage are $28 \%$ of those for the fresh cement phase $\left(7.1 \times 10^{3} \mu \mathrm{g} / \mathrm{L}\right)$. In the case of tank C-203, the chromium release concentration $\left(1.3 \times 10^{4} \mu \mathrm{g} / \mathrm{L}\right)$ for the calcite stage is similar to the fresh cement phase $\left(1.1 \times 10^{4} \mu \mathrm{g} / \mathrm{L}\right)$. It had been hypothesized in Deutsch et al. (2005, Section 3.8) that the high pH $(>12)$ of the fresh cement solution enhanced chromium release compared to the lower $\mathrm{pH}$ ( 8 to 10.5) of the calcite stage. This would explain the higher chromium release concentrations for residual waste in tank C-202 but does not explain the similar release concentrations for tank C-203. 
Table 6.4. Waste and Contaminant Release Concentrations for Release Model (from Deutsch et al. 2007c)

\begin{tabular}{|c|c|c|c|c|}
\hline Tank & Release Scenario & Component & $\begin{array}{l}\text { Waste Conc. } \\
\mu \mathrm{g} / \mathrm{g} \text { Waste }\end{array}$ & $\begin{array}{c}\text { Max. Release } \\
\text { Conc. } \mu \mathrm{g} / \mathrm{L}\end{array}$ \\
\hline \multirow[t]{8}{*}{ C-202 } & Calcite $\left[\mathrm{CaCO}_{3}\right]$ & 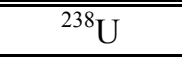 & $2.4 \times 10^{5}$ & $6.1 \times 10^{4}$ \\
\hline & Fresh cement $\left[\mathrm{Ca}(\mathrm{OH})_{2}\right]$ & ${ }^{238} \mathrm{U}$ & $2.4 \times 10^{5}$ & $1.7 \times 10^{3}$ \\
\hline & Calcite $\left[\mathrm{CaCO}_{3}\right]$ & $\mathrm{Cr}$ & $1.0 \times 10^{4}$ & $2.0 \times 10^{3}$ \\
\hline & Fresh cement $\left[\mathrm{Ca}(\mathrm{OH})_{2}\right]$ & $\mathrm{Cr}$ & $1.0 \times 10^{4}$ & $7.1 \times 10^{3}$ \\
\hline & Calcite $\left[\mathrm{CaCO}_{3}\right]$ & ${ }^{99} \mathrm{Tc}$ & 0.23 & 0.041 \\
\hline & Fresh cement $\left[\mathrm{Ca}(\mathrm{OH})_{2}\right]$ & ${ }^{99} \mathrm{Tc}$ & 0.23 & 0.054 \\
\hline & Calcite $\left[\mathrm{CaCO}_{3}\right]$ & ${ }^{129} \mathrm{I}$ & 12 & 0.83 \\
\hline & Fresh cement $\left[\mathrm{Ca}(\mathrm{OH})_{2}\right]$ & ${ }^{129} \mathrm{I}$ & 12 & 0.96 \\
\hline \multirow[t]{8}{*}{ C-203 } & Calcite $\left[\mathrm{CaCO}_{3}\right]$ & ${ }^{238} \mathrm{U}$ & $5.9 \times 10^{5}$ & $5.1 \times 10^{5}$ \\
\hline & Fresh cement $\left[\mathrm{Ca}(\mathrm{OH})_{2}\right]$ & ${ }^{238} \mathrm{U}$ & $5.9 \times 10^{5}$ & $3.0 \times 10^{5}$ \\
\hline & Calcite $\left[\mathrm{CaCO}_{3}\right]$ & $\mathrm{Cr}$ & $4.3 \times 10^{3}$ & $1.3 \times 10^{4}$ \\
\hline & Fresh cement $\left[\mathrm{Ca}(\mathrm{OH})_{2}\right]$ & $\mathrm{Cr}$ & $4.3 \times 10^{3}$ & $1.1 \times 10^{4}$ \\
\hline & Calcite $\left[\mathrm{CaCO}_{3}\right]$ & ${ }^{99} \mathrm{Tc}$ & 0.11 & 0.16 \\
\hline & Fresh cement $\left[\mathrm{Ca}(\mathrm{OH})_{2}\right]$ & ${ }^{99} \mathrm{Tc}$ & 0.11 & 0.38 \\
\hline & Calcite $\left[\mathrm{CaCO}_{3}\right]$ & ${ }^{129} \mathrm{I}$ & 0.87 & 0.98 \\
\hline & Fresh cement $\left[\mathrm{Ca}(\mathrm{OH})_{2}\right]$ & ${ }^{129} \mathrm{I}$ & 0.87 & 1.0 \\
\hline
\end{tabular}

The residual waste concentration of technetium-99 in C-202 $(0.23 \mu \mathrm{g} / \mathrm{g}$ waste $)$ is more than twice that of C-203 $(0.11 \mu \mathrm{g} / \mathrm{g}$ waste). The technetium-99 release concentrations are generally based on estimated solution concentrations because levels were below the EQL. Maximum release concentrations determined for C-202 for the calcite scenario $(0.041 \mu \mathrm{g} / \mathrm{L})$ are similar to the $\mathrm{C}-202$ fresh cement scenario $(0.054 \mu \mathrm{g} / \mathrm{L})$. For C-203, the maximum technetium-99 release concentrations are $0.16 \mu \mathrm{g} / \mathrm{L}$ for the calcite scenario and $0.38 \mu \mathrm{g} / \mathrm{L}$ for the fresh cement scenario.

Concentrations of iodine-129 in C-202 (12 $\mu \mathrm{g} / \mathrm{g}$ waste) and C-203 (0.87 $\mu \mathrm{g} / \mathrm{g}$ waste) residual wastes differ by a factor of 14 . Maximum iodine-129 release concentrations determined for C-202 for the calcite scenario $2(0.83 \mu \mathrm{g} / \mathrm{L})$ are similar to the $\mathrm{C}-202$ fresh cement phase $(0.96 \mu \mathrm{g} / \mathrm{L})$. The $\mathrm{C}-203$ maximum iodine-129 release concentrations are similar to those for $\mathrm{C}-202$ residual waste. Maximum iodine-129 release concentrations determined for $\mathrm{C}-203$ for the calcite scenario $(0.98 \mu \mathrm{g} / \mathrm{L})$ are also similar to the C-203 fresh cement phase $(1.0 \mu \mathrm{g} / \mathrm{L})$. 


\subsection{Discussion}

The process of estimating potential future contaminant releases from closed Hanford SSTs is in its early stages. As of fall 2007, only 7 of the 149 SSTs have been retrieved, and release rates have been measured for only 4 of the 7 retrieved tanks. It has not been decided what material to use to fill the tanks, and other questions dealing with the closure process (such as what to do with the piping systems in the tank farms) remain to be resolved. Therefore, the actual environmental conditions under which contaminants will be subject to release are uncertain. The release models developed with available samples take into account some of this uncertainty by providing results for two closure scenarios (inert sand/gravel and cementitious material); however, these tank fill scenarios do not cover all closure possibilities. For example, a reducing agent may be added to the filling material to, at least temporarily, create reducing conditions in the residual material that will lower the solubility of technetium, chromium, uranium, and the other actinides of interest. Also, because of the difficulty in identifying and quantifying trace constituents such as technetium-99 and iodine-129 in the residual waste and the lack of chemical equilibrium between the solution and solid phases in the leaching tests, it has not been possible to develop mechanistic contaminant release models. The only models of contaminant release from residual waste developed to date have been empirical models that do not identify the actual release process that is operative and are not amenable to modification if future conditions controlling release are different from those under which the empirical models were developed. This section provides a discussion of some of the technical challenges that have been encountered in studying residual tank waste and provides recommendations for addressing the challenges.

\subsection{Improved Testing Methodologies for Residual Waste}

Release rate data collected for residual tank waste has relied primarily on single-contact and periodic replenishment leaching tests. In most cases, the highest concentrations of important contaminants of interest (technetium-99, uranium-238, iodine-129, and chromium) are released during the first contact of any leach test, and concentrations decrease systematically with each subsequent leach. In some cases (for example, tank C-106), a significant rebound was observed when longer contact times were used, even after five previous leaches. These results suggest a complex release mechanism that is not fully understood and requires the use of a relatively conservative empirical solubility release model. To better understand and quantify the release process, it has been suggested that single-pass flow-through tests (e.g., McGrail et al. 2000) and/or stop-flow column techniques (Qafoku et al. 2005) be used on residual waste samples. Data from the SPFT could be used to develop input parameters for a kinetic model of contaminants release, as is being done for glass waste forms (McGrail et al. 2000; Pierce et al. 2004).

The SEM/EDS techniques used on the residual waste samples to date provide a wide spectrum of important characterization information for such samples. However, these techniques are not adequate for characterization of solids at the submicrometer-nanometer size range. The use of TEM and associated elemental analysis capabilities to better understand the crystallinity and aggregate nature of these waste samples has been suggested by project team members and outside reviewers. To date, TEM has not been tried because of other project priorities and potential safety and cost issues thought to be associated with the preparation and analysis of radioactive residual waste by TEM. 
Studies are proposed to evaluate the technical feasibility, sample preparation requirements, and associated costs of using "hot" TEM instrumentation available at PNNL to characterize radioactive, dispersible SST residual waste (see also Section 2.2.3). The evaluation could also address issues such as identification of appropriate "target" particles as identified by SEM/EDS (such as $x-y$ mapping of "target" particles on a SEM sample mount); characterization by TEM; and adequacy of textural, crystallinity, and composition information that may be provided by such a TEM analysis. The results of this study would provide information to better assess the cost-effectiveness and expected characterization information that would be gained from including TEM analysis in a multi-tiered approach to study and develop sourceterm models for SST residual wastes.

\subsection{Improved Simulation of Long-Term Tank Environment}

Residual waste in an SST is in contact with a carbon steel liner that has corroded to iron oxides to some extent. Beneath the carbon steel is the concrete shell of the tank, which provides an additional barrier between the waste and the natural environment. Contaminants released from the residual tank waste by dissolving in water must pass through the corroded steel and the concrete shell, both of which will react to some extent with the dissolved contaminants. Iron oxides in the corroded steel are excellent adsorbers for many contaminants, and uncorroded, zero-valent iron steel is a strong reductant that may reduce redox-sensitive elements (like uranium, technetium, and chromium), sequestering the contaminants in low-solubility solid phases. The concrete may also be reactive and produce high-pH conditions because of residual portlandite $\left[\mathrm{Ca}(\mathrm{OH})_{2}\right]$ in the cement. Alkaline conditions may also lower the solubility of some minerals. To evaluate the complete contaminant release pathway to the closed tank system, it will be necessary to study the interactions of dissolved residual waste constituents with these other components of the closed tank.

One of the scenarios for the current test methodology for tank waste assumes that the tank may be filled with a cementitious material. The waste samples are leached with $\mathrm{Ca}(\mathrm{OH})_{2}$-saturated and $\mathrm{CaCO}_{3}$ saturated solutions to simulate leachants that may be produced over time from the cement. It is likely that some of the waste will be incorporated to some extent in the cement/grout used to fill the tanks, and this process should also be tested to better evaluate contaminant release. Cement should be placed in contact with residual waste and allowed to cure. Water leach tests should then be conducted on the cured samples to determine the impact of grouting on leach rates of contaminants of interest. In addition the samples should be dissected and investigated/analyzed using various techniques such as SEM/EDS, auto radiography, and synchrotron-based $x$-ray techniques including $\mu \mathrm{XRF}$ to study the chemical interactions between the cement phase and each waste material. These measurements will help identify the mechanisms by which surface contact and associated reactions between the cement and tank residual waste may affect the release of COIs.

\subsection{Occurrence and Release of Technetium-99 from Residual Waste}

Until PNNL's recent studies of C-103 residual waste (Cantrell et al. 2007a), PNNL studies of residual waste from the SSTs had not been successful at identifying the solid phase(s) that are sequestering technetium-99. This determination is difficult due to the multi-phase assemblage of crystalline and amorphous solids that make up the waste, the complexity of the structure of multi-phase aggregates and mineral coatings that exist in the residual tank waste, and the low concentrations of technetium-99 in the bulk solid waste relative to the concentrations of the other elements. Selective extraction studies by Deutsch et al. $(2005,2007 b)$ and Krupka et al. (2004) suggest that technetium-99 is likely associated with 
iron hydroxide/oxide solids present in the tank waste. Technetium was recently measured in three iron oxide/hydroxide particles in C-103 residual waste by EDS (Cantrell et al. 2007a). As a trace constituent in iron hydroxide/oxide phases, technetium- 99 release will not be controlled by a technetium solid but by the low solubility and slow dissolution rates of the host iron-containing mineral(s). Given the omnipresence of iron oxides in SST residual wastes and their possible role as a host for technetium, as well as other contaminants of interest such as chromium and iodine-129, iron oxides are key phases to be considered in the development of source-term release models for the residual tank waste. However, because of a lack of detailed phase chemistry and solubility information, conservative approaches have been used for incorporating iron oxides solubilities and contaminant release rates in the COI release models.

To bridge this information gap, two series of laboratory studies have been proposed to investigate the solubilities and crystallization history of iron oxides that are precipitated under controlled conditions at tank-waste $\mathrm{pH}$ conditions (see also Section 2.2.3). In the first series, iron oxides will be precipitated at high-pH-high-sodium conditions in the presence of a series of different dissolved chromium or manganese concentrations. The solubilities of the iron oxides will be quantified, and phase characteristics of these solid reaction products will be determined by XRD, SEM/EDS, and other techniques, to evaluate the influence of chromium and manganese on the solubilities and crystallization history of iron oxides, including the possible formation of metastable amorphous iron oxides. The second series of experiments will be similar to the first with the addition of technetium-99 as a trace constituent in the system. The solubilities and phase characterization information derived from these two series of experiments will provide a more accurate understanding of the incorporation of specific COIs in coprecipitated iron oxides and their release from SST residual wastes. If successful, similar experiments with the other trace COIs and ferric iron precipitation will be performed to attempt to quantify in a more mechanistic fashion the association of COIs with the iron oxides.

\subsection{Presence and Impact of Organic Complexants on Contaminant Mobility in Residual Tank Waste}

Organic extraction solvents and organic complexants were used in some of the processes at Hanford to extract plutonium from spent nuclear fuel. The principal extraction solvents used were TBP and mixtures of NPHs. TBP is the extraction agent, while NPHs are used as diluents and do not interact with metal ions. TBP is a relatively weak extractant, is slightly soluble in water, and requires contact with a concentrated salt or acid solution for effective extraction (Schulz and Navratil 1984). As such, TBP is not considered to have significant potential for mobilizing actinides from residual tank waste.

Other processes employed in the past at Hanford used large quantities of organic complexants. The quantities of the principal complexants used at Hanford are shown in Table 7.1 (Allen 1976; Meacham 1996). These organics as well as others that were used in smaller quantities (such as NTA, ED3A, oxalate, IDA, and s-EDDA) all have relatively high-stability constants for multivalent cations such as actinides and have a high potential for mobilizing multivalent metal contaminants. 
Table 7.1. Quantities of the Principal Organic Complexants Used at Hanford (from Allen 1976; Meacham 1996)

\begin{tabular}{||l|c||}
\hline \multicolumn{1}{|c|}{ Complexant } & Quantity (metric tons) \\
\hline \hline Glycolic acid & 880 \\
\hline Citric acid & 850 \\
\hline Hydroxyethylethylenediaminetriacetic acid (HEDTA) & 830 \\
\hline Ethylenediaminetetraacetic acid (EDTA) & 220 \\
\hline
\end{tabular}

As part of the routine IC analyses conducted for the residual tank waste testing work, the low molecular weight organic acids oxalate, acetate, and formate are quantified. Because the higher-molecular weight complexants are likely to have the greatest impact on contaminant mobilization and measurements of these components have been made on only a small fraction of the SST wastes and/or supernatant fluids, additional measurements of higher-molecular weight complexants in residual tank waste would provide useful information.

The most direct approach to evaluate the significance of complexants on contaminant mobility in residual tanks waste would be to combine the routine IC measurements of low-molecular weight organic acids with measurements of higher-molecular weight complexants and complexants fragments. Campbell et al. (1994, 1995, 1996a, 1996b) have developed analytical methods for measuring complexants in high salt tank waste matrices.

Using measured complexant concentrations remaining in residual waste along with measured values of major ions, trace metals, and contaminants of interest, thermodynamic modeling could be applied to evaluate the significance of the complexants with respect to their potential for mobilizing COIs. An alternative approach could focus on leach-testing archived SST waste samples that have been found previously to contain high concentrations of high-molecular weight complexants and complexant fragments. These samples would be most likely to show mobilization by organics if it occurs. If COIs in these highly organic-bearing tank sludges are not mobilized at significantly higher concentrations than in tests performed on the available residual wastes, it is unlikely that complexants will be capable of mobilizing contaminants from any residual tank waste.

\subsection{Data Uncertainty}

The estimation of contaminant release rates from retrieved tanks is based on a limited number of samples (two or three) from a few locations (one to three) in each tank. Because the tanks are large (20 to $75 \mathrm{ft}$ in diameter), grab samples of residual waste from a few locations may not be representative of the entire mass of waste left in the tanks. The number of available samples is limited by the difficulty of collecting samples remotely from the few access ports in the top of each tank. However, efforts are currently under way to more completely sample one tank to see if there is significant variability in concentrations of the waste components across the extent of a tank bottom. One process that might potentially lead to a relatively uniform distribution of waste across a tank is retrieval of the waste, which is commonly done by creating a slurry with water so that the waste can be pumped out or vacuumed with a remotely controlled crawler. These retrieval processes may minimize anomalous waste characteristics so that the final residual waste samples are representative of the majority of the waste remaining in the tank. 
Future leachants that might be produced by a cementitious material placed on top of the tank residual waste are assumed to be dominated by $\mathrm{Ca}(\mathrm{OH})_{2}$ during the "fresh" cement phase and by $\mathrm{CaCO}_{3}$ during the "aged" cement phase. In addition to the uncertainty generated by using these simplified leachants, it is not known when the fresh leachant will be exhausted by weathering of the cement and when the aged leachant becomes the active leaching agent. It is very difficult to accelerate the leaching of a cement monolith and to simulate weathering for time periods up to tens of thousands of years. Unless new methods are developed to accurately carbonate and age cement, the decision as to when to switch the release rate from that of fresh to aged cement likely will be based on professional judgment, or the higher of the two release rates will be used for the entire time of the performance assessment. 


\subsection{References}

Agnew SF, J Boyer, RA Crobin, TB Duran, JR FitzPatrick, KA Jurgensen, TP Ortiz, and BL Young. 1997. Hanford Tank Chemical and Radionuclide Inventories: HDW Model Rev. 4. LA-UR-96-3860, Los Alamos National Laboratory, Los Alamos, New Mexico.

Allard B, L Allicin, S Hoglund, and K Anderson. 1984. Sorption of Cs, I and Actinides in Concrete Systems. KGS 84-15, Swedish Nuclear Fuel and Waste Management Co., Stockholm, Sweden.

Allen GK. 1976. Estimated Inventory of Chemicals Added to the Underground Waste Tanks, 1944 to 1975. ARH-CD-6108, Atlantic Richfield Hanford Company, Richland, Washington.

Ames LL and D Rai. 1978. Radionuclide Interactions with Soil and Rock Media. Volume 1: Processes Influencing Radionuclide Mobility and Retention, Element Chemistry and Geochemistry, and Conclusions and Evaluations. EPA 520/6-78-007-a, U.S. Environmental Protection Agency, Las Vegas, Nevada.

Ames LL, JE McGarrah, BA Walker, and PF Salter. 1982. "Sorption of Uranium and Cesium by Hanford Basalts and Associated Secondary Smectites.” Chemical Geology 35:205-225.

Anderson JD. 1990. A History of the 200 Area Tank Farms. WHC-MR-0132, Westinghouse Hanford Company, Richland, Washington.

Arey BW, HT Schaef, KM Krupka, and WJ Deutsch. 2005. “Application of Scanning Electron Microscopy to Characterization of Radioactive Solid Waste from Underground Storage Tanks" (extended abstract and poster). Presented to Microscopy and Microanalysis 2005, Honolulu, Hawaii, July 31August 4, 2005.

Atkins M and FP Glasser. 1992. “Application of Portland-Cement-Based Materials to Radioactive Waste Immobilization.” Waste Management 12:105-131.

Bacon DH, MD White, and BP McGrail. 2004. Subsurface Transport Over Reactive Multiphases (STORM): A Parallel, Coupled, Nonisothermal Multiphase Flow, Reactive Transport, and Porous Medium Alteration Simulator, Version 3.0. PNNL-14783, Pacific Northwest National Laboratory, Richland, Washington.

Baes CF Jr. and RE Mesmer. 1976. The Hydrolysis of Cations. John Wiley \& Sons, New York.

Ball JW and DK Nordstrom. 1998. "Critical Evaluation and Selection of Standard State Thermodynamic Properties for Chromium Metal and its Aqueous Ions, Hydrolysis Species, Oxides, and Hydroxides." Journal of Chemical and Engineering Data 43:895-918.

Barney GS. 1996. The Solubilities of Significant Organic Compounds in HLW Tank Supernatant Solutions-FY 1996 Progress Report. WHC-EP-0899-1, Westinghouse Hanford Company, Richland, Washington. 
Bartlett R and B James. 1979. "Behavior of Chromium in Soils: III. Oxidation.” Journal of Environmental Quality 8(1):31-35.

Bartlett RJ and JM Kimble. 1976a. "Behavior of Chromium in Soils: I. Trivalent Forms." Journal of Environmental Quality 5(4):379-383.

Bartlett RJ and JM Kimble. 1976b. "Behavior of Chromium in Soils: II. Hexavalent Forms." Journal of Environmental Quality 5(4):383-386.

Bayliss S, A Haworth, R McCrohon, AD Moreton, P Oliver, NJ Pilkington, AJ Smith, and JL SmithBriggs. 1992. "Radioelement Behavior in a Cementitious Environment." In Scientific Basis for Nuclear Waste Management XV, CG Sombret (ed.), Materials Research Society Symposium Proceedings, Volume 257, pp. 641-648. Materials Research Society, Pittsburgh, Pennsylvania.

Beasley TM and HV Lorz. 1984. "A Review of the Biological and Geochemical Behavior of Technetium in the Marine Environment." In Technetium in the Environment, G Desment and C Myttenaere (eds.), pp. 197-216. Elsevier, New York.

Bechtold DB, GA Cooke, DL Herting, JC Person, RS Viswanath, and RW Warrant. 2003. Laboratory Testing of Oxalic Acid Dissolution of Tank 241-C-106 Sludge. RPP-17158, Rev. 0, Fluor Hanford, Inc., Richland, Washington.

Bernhard G, G Geipel, V Brendler, and H Nitsche. 1996. "Speciation in Uranium in Seepage Waters of a Mine Tailing Pile Studied by Time Resolved Laser-Induced Fluorescence Spectroscopy." Radiochimica Acta 74:87-91.

Bernhard G, G Geipel, T Reich, V Brendler, S Amayri, and H Nitsche. 2001. "Uranyl(VI) Carbonate Complex Formation: Validation of the $\mathrm{Ca}_{2} \mathrm{UO}_{2}\left(\mathrm{CO}_{3}\right)_{3}$ (aq.) Species." Radiochimica Acta 89:511-518.

Bethke CM. 2006. The Geochemist's Workbench ${ }^{\circledR}$ Release 6.0. Hydrogeology Program, University of Illinois, Urbana.

Bickmore BR, KL Nagy, JS Young, and JW Drexler. 2001. "Nitrate-Cancrinite Precipitation on Quartz Sand in Simulated Hanford Tank Solutions." Environmental Science and Technology 35:4481-4486.

Blowes DW and CJ Ptacek. 1992. "Geochemical Remediation of Groundwater by Permeable Reactive Walls: Removal of Chromate by Reaction with Iron-Bearing Solids." Proceedings of the Subsurface Restoration Conference, pp. 214-216. Rice University Press, Houston, Texas.

Bondietti EA and CW Francis. 1979. "Geologic Migration Potentials of Technetium-99 and Neptunium-237.” Science 203:1337-1340.

Borovec Z, B Kribek, and V Tolar. 1979. "Sorption of Uranyl by Humic Acids.” Chemical Geology 27:39-46.

Bradbury MH and FA Sarott. 1995. Sorption Databases for the Cementitious Near Field of a L/ILW Repository for Performance Assessment. PSI Bericht 95-06, Paul Scherrer Institut, CH-5232 Villigen PSI, Switzerland. 
Bradbury MH and LR Van Loon. 1998. Cementitious Near-Field Sorption Data Bases for Performance Assessment of a L/ILW Repository in a Palfris Marl Host Rock. CEM 94: UPDATE I, June 1997. PSI Bericht. 98-01, Paul Scherrer Institut, CH-5232 Villigen PSI, Switzerland.

Brown CF, KN Geiszler, and T Vickerman. 2005. "Extraction and Quantitative Analysis of Iodine in Solid and Solution Matrices.” Analytical Chemistry 77:7062-7066.

Burns PC and R Finch (eds.). 1999. "Uranium: Mineralogy, Geochemistry and the Environment." Volume 38 in Reviews in Mineralogy. Mineralogical Society of America, Washington, D.C.

Byegård J, Y Albinsson, G Skarnemark, and M Skålberg. 1992. "Field and Laboratory Studies of the Reduction and Sorption of Technetium(VII).” Radiochimica Acta 58/59:239-244.

Campbell JA, SA Clauss, V Hoopes, J Rau, KL Wahl, KE Grant, GM Mong, and RT Steele. 1994. Flammable Gas Safety Program, Analytical Methods Development: FY 1993 Progress Report.

PNL-9062, Pacific Northwest Laboratory, Richland, Washington.

Campbell JA, SA Clauss, V Hoopes, J Rau, KL Wahl, KE Grant, GM Mong, and RT Steele. 1995. Organic Analysis and, Analytical Methods Development: FY 1995 Progress Report. PNL-10776, Pacific Northwest Laboratory, Richland, Washington.

Campbell JA, SA Clauss, KE Grant, V Hoopes, GM Mong, JK Rau, RT Steele, and KL Wahl. 1996a. Flammable Gas Safety Program: Actual Waste Organic Analysis: FY 1996 Progress Report. PNNL-11307, Pacific Northwest National Laboratory, Richland, Washington.

Campbell JA, KL Wahl, SA Clauss, KE Grant, V Hoopes, GM Mong, JK Rau, and RT Steele. 1996b. Organic Tanks Safety Program, Advanced Organic Analysis: FY 1996 Progress Report. PNNL-11309, Pacific Northwest National Laboratory, Richland, Washington.

Campbell JA, AK Sharma, SA Clauss, GM Mong, and DL Bellofatto. 1998. Organic Speciation of AS-102, BX-104, C-104, C-201, and C-202 Tank Wastes. PNNL-11955, Pacific Northwest National Laboratory, Richland, Washington.

Cantrell KJ and RH Byrne. 1987. "Rare Earth Element Complexation by Carbonate and Oxalate Ions." Geochimica et Cosmochimica Acta 51:597-605.

Cantrell KJ, RJ Serne, and GV Last. 2003. Hanford Contaminant Distribution Coefficient Database and Users Guide. PNNL-13895, Rev. 1, Pacific Northwest National Laboratory, Richland, Washington.

Cantrell KJ, KM Krupka, WJ Deutsch, and MJ Lindberg. 2006. "Residual Waste from Hanford Tanks 241-C-203 and 241-C-204. 2. Contaminant Release and Modeling." Environmental Science and Technology 40(12):3755-3761.

Cantrell KJ, KM Krupka, MJ Lindberg, KN Geiszler, BW Arey, HT Schaef, and CF Brown. 2007a. Hanford Tank 241-C-103 Residual Waste Composition and Leaching Test Data Report. PNNL-16738, Pacific Northwest National Laboratory, Richland, Washington. 
Cantrell KJ, JM Zachara, PE Dresel, KM Krupka, and RJ Serne. 2007b. Geochemical Processes Data Package for the Vadose Zone in the Single-Shell Tank Waste Management Areas at the Hanford Site. PNNL-16663, Pacific Northwest National Laboratory, Richland, Washington.

Chisholm-Brause C, SD Conradson, CT Buscher, PG Eller, and DE Morris. 1994. "Speciation of Uranyl Sorbed at Multiple Binding Sites on Montmorillonite." Geochimica et Cosmochimica Acta 58(17):3625-3631.

Conner JM. 1996. Tank Characterization Report for Single-Shell Tank 241-C-204. WHC-SD-WMER-479 Rev. 0, Westinghouse Hanford Company, Richland, Washington.

Coughtrey PJ, D Jackson, and MC Thorne. 1983. Radionuclide Distribution and Transport in Terrestrial and Aquatic Ecosystems. A Critical Review of Data. AA Balkema, Rotterdam, Netherlands.

Davis JA and JO Leckie. 1980. "Surface Ionization and Complexation at the Oxide/Water Interface. 3. Adsorption of Anions." Journal of Colloid and Interface Science 74:32-43.

Davis A and RL Olsen. 1995. "The Geochemistry of Chromium Migration and Remediation in the Subsurface." Ground Water 33(5):759-768.

Deutsch WJ, KM Krupka, KJ Cantrell, CF Brown, MJ Lindberg, HT Schaef, SM Heald, BW Arey, and RK Kukkadapu. 2005. Advances in Geochemical Testing of Key Contaminants in Residual Hanford Tank Waste. PNNL-15372, Pacific Northwest National Laboratory, Richland, Washington.

Deutsch WJ, KM Krupka MJ Lindberg, KJ Cantrell, CF Brown, and HT Schaef. 2006. Hanford Tanks 241-C-106: Impact of Cement Reactions on Release of Contaminant from Residual Waste. PNNL-15544, Pacific Northwest National Laboratory, Richland, Washington.

Deutsch WJ, KM Krupka MJ Lindberg, KJ Cantrell, CF Brown, and HT Schaef. 2007a. Hanford Tanks 241-C-106: Residual Waste Contaminant Release Model and Supporting Data. PNNL-15187, Rev. 1, Pacific Northwest National Laboratory, Richland, Washington.

Deutsch WJ, KM Krupka, MJ Lindberg, KJ Cantrell, CF Brown, and HT Schaef. 2007b. Hanford Tanks 241-C-203 and 241-C-204: Residual Waste Contaminant Release Model and Supporting Data.

PNNL-14903, Rev. 1, Pacific Northwest National Laboratory, Richland, Washington.

Deutsch WJ, KM Krupka MJ Lindberg, KJ Cantrell, CF Brown, SV Mattigod, HT Schaef, and BW Arey. 2007c. Hanford Tanks 241-C-202 and 241-C-203 Residual Waste Contaminant Release Models and Supporting Data. PNNL-16229, Pacific Northwest National Laboratory, Richland, Washington.

DOE ORP. 2006. Initial Single-Shell Tank System Performance Assessment for the Hanford Site. DOE/ORP-2005-01, U.S. Department of Energy, Office of River Protection, Richland, Washington.

Doner HE and WC Lynn. 1977. "Carbonate, Halide, Sulfate, and Sulfide Minerals." In Minerals in Soil Environments, JB Dixon and SB Weed (eds.), pp. 75-98. Soil Society of America, Madison, Wisconsin. 
Dong WM, WP Ball, CX Liu, ZM Wang, AT Stone, J Bai, and JM Zachara. 2005. "Influence of Calcite and Dissolved Calcium on Uranium(VI) Sorption to a Hanford Subsurface Sediment." Environmental Science and Technology 39(20):7949-7955.

Duff MC and C Amrhein. 1996. "Uranium(VI) Adsorption on Goethite and Soil in Carbonate Solutions.” Soil Science Society of America Journal 60(5):1393-1400.

Eary LE and D Rai. 1987. "Kinetics of Chromium(III) Oxidation to Chromium(VI) by Reaction with Manganese Dioxide." Environmental Science and Technology 21:1187-1193.

Ecology - Washington State Department of Ecology, U.S. Environmental Protection Agency, and U.S. Department of Energy. 1989. Hanford Federal Facility Agreement and Consent Order. Document No. 89-10, as amended (The Tri-Party Agreement), Olympia, Washington.

EPA - see U.S. Environmental Protection Agency.

Eriksen TE and D Cui. 1991. On the Interaction of Granite with Tc(IV) and Tc(VII) in Aqueous Solution. SKB Technical Report 91-47, Svensk Kärnbränslehantering AB (Swedish Nuclear Fuel and Waste Management Company), Stockholm, Sweden.

Eriksen TE, P Ndalamba, J Bruno, and M Caceci. 1992. "The Solubility of $\mathrm{TcO}_{2} \cdot \mathrm{nH}_{2} \mathrm{O}$ in Neutral to Alkaline Solutions under Constant p $_{\mathrm{CO} 2 . "}$ Radiochimica Acta 58/59:67-70.

Falck WE. 1991. CHEMVAL Project. Critical Evaluation of the CHEMVAL Thermodynamic Database with Respect to its Contents and Relevance to Radioactive Waste Disposal at Sellafield and Dounreay. DOE/HMIP/RR/92.064, Department of Environment, Her Majesty's Stationary Office, London, England.

Felmy AR, Y Xia, and Z Wang. 2005. "The Solubility Product of $\mathrm{NaUO}_{2} \mathrm{PO}_{4} \cdot x \mathrm{H}_{2} \mathrm{O}$ Determined in Phosphate and Carbonate Solutions." Radiochimica Acta 93(7):401-408.

Finch R and T Murakami. 1999. "Systematics and Paragenesis of Uranium Minerals." In Uranium: Mineralogy, Geochemistry and the Environment. Reviews in Mineralogy, PC Burns and R Finch (eds.), Volume 38, pp. 91-179. Mineralogical Society of America, Washington, D.C.

Fox PM, JA Davis, and JM Zachara. 2006. “The Effect of Calcium on Aqueous Uranium(VI) Speciation and Adsorption to Ferrihydrite and Quartz." Geochimica et Cosmochimica Acta 70(6):1379-1387.

Fredrickson JK, HM Kostandarithes, SW Li, AE Plymale, and MJ Daly. 2000. "Reduction of Fe(III), $\mathrm{Cr}(\mathrm{VI}), \mathrm{U}(\mathrm{VI})$, and Tc(VII) by Deinococcus radiodurans R1.” Applied and Environmental Microbiology 66:2006-2011.

Frondel C. 1958. Systematic Mineralogy of Uranium and Thorium. Geological Survey Bulletin 1064, U.S. Geological Survey, Washington, D.C.

Garrels RM and CL Christ. 1965. Solutions, Minerals, and Equilibria. Freeman, Cooper and Co., San Francisco, California. 
Glasser FP and M Atkins. 1994. "Cements in Radioactive Waste Disposal.” MRS Bulletin, XIX(12):33-38

Gorski B and H Koch. 1970. "Uber die Komplexbideling von Technetium mit Chelatbildenden Ligande - II." Journal of Inorganic and Nuclear Chemistry 32:3831-3836.

Grant KE, RB Lucke, SA Clauss, GM Mong, BD Lerner, and JA Campbell. 1996. "Qualitative Determination of Low-Molecular-Weight Organic Acids in Mixed Hazardous Wastes Using Thermospray Liquid Chromatography/Mass Spectrometry." Journal of Radioanalytical and Nuclear Chemistry, Articles 203(2):247-261.

Grenthe I, J Fuger, RJM Konings, RJ Lemire, AB Muller, C Nguyen-Trung, and H Wanner. 1992. Chemical Thermodynamics, Volume 1: Chemical Thermodynamics of Uranium. North-Holland, Elsevier Science Publishing Company, Inc., New York.

Griffin RA, AK Au, and RR Frost. 1977. "Effect of pH on Adsorption of Chromium from LandfillLeachate by Clay Minerals." Journal of Environmental Science and Health 12:431-449.

$\mathrm{Gu} \mathrm{B}$ and RK Schulz. 1991. Anion Retention in Soil: Possible Application to Reduce Migration of Buried Technetium and Iodine. NUREG/CR-5464, U.S. Nuclear Regulatory Commission, Washington, D.C.

Guillaumont R, T Fanghänel, J Fuger, I Grenthe, V Neck, DA Palmer, and MH Rand. 2003. Chemical Thermodynamics, Volume 5. Update on the Chemical Thermodynamics of Uranium, Neptunium, Plutonium, Americium and Technetium. North-Holland, Elsevier Science Publishing Company, Inc., New York.

Haines RI, DG Owen, and TT Vandergraaf. 1987. "Technetium-Iron Oxide Reactions Under Anaerobic Conditions: A Fourier Transform Infrared, FTIR Study.” Nuclear Journal of Canada 1:32-37.

Helgeson HC. 1969. "Thermodynamics of Hydrothermal Systems at Elevated Temperatures and Pressures." American Journal of Science 267(7):729-804.

Helgeson HC, JM Delany, HW Nesbitt, and DK Bird. 1978. "Summary and Critique of the Thermodynamic Properties of Rock-Forming Minerals." American Journal of Science 278-A:1-229.

Hem JD. 1986. Study and Interpretation of Chemical Characterizations of Natural Water. Water-Supply Paper 2254, U.S. Geological Survey, Alexandria, Virginia.

Hogland S, L Eliasson, B Allard, K Andersson, and B Torstenfelt. 1985. "Sorption of Some Fission Products and Actinides in Concrete Systems." In Scientific Basis for Nuclear Waste Management IX, L0 Werme (ed.), pp. 683-690. Materials Research Society Symposium Proceedings, Volume 50. Materials Research Society, Pittsburgh, Pennsylvania.

Horton DG. 2007. Data Package for Past and Current Groundwater Flow and Contamination beneath Single-Shell Tank Waste Management Areas. PNNL-15837, Pacific Northwest National Laboratory, Richland, Washington. 
Hsi C and L Langmuir. 1985. "Adsorption of Uranyl onto Ferric Oxyhydroxides: Application of the Surface Complexation Site-Binding Model.” Geochimica et Cosmochimica Acta 49:1931-1941.

Hughes MA and FJC Rossotti. 1987. A Review of Some Aspects of the Solution Chemistry of Technetium. AERE-R 12820, University of Oxford, Oxford, England.

IAEA (International Atomic Energy Agency). 1993. Improved Cement Solidification of Low and Intermediate Level Radioactive Wastes. Technical Reports Series No. 350, International Atomic Energy Agency, Vienna, Austria.

James BR and RJ Bartlett. 1983a. "Behavior of Chromium in Soils: V. Fate of Organically Complexed Cr(III) Added to Soil.” Journal of Environmental Quality 12(2):169-172.

James BR and RJ Bartlett. 1983b. "Behavior of Chromium in Soils. VI. Interactions Between Oxidation-Reduction and Organic Complexation.” Journal of Environmental Quality 12(2):173-176.

James BR and RJ Bartlett. 1983c. "Behavior of Chromium in Soils: VII. Adsorption and Reduction of Hexavalent Forms.” Journal of Environmental Quality 12(2):177-181.

Johnson CA and AG Xyla. 1991. "The Oxidation of Chromium(III) to Chromium(VI) on the Surface of Manganite ( $\gamma$-MnOOH)." Geochimica et Cosmochimica Acta 55:2861-2866.

Johnson KS. 1994. “Iodine.” In Industrial Minerals and Rocks, DC Carr (ed.), pp. 583-588. Society for Mining, Metallurgy, and Exploration, Inc., Littleton, Colorado.

Jove Colon CF, A Navrotsky, JL Krumhansl, M Nyman, and Q Liu. 2004. A Comprehensive Study of the Solubility, Thermochemistry, Ion Exchange, and Precipitation Kinetics of $\mathrm{NO}_{3}$ Cancrinite and $\mathrm{NO}_{3}$ Sodalite (Project No.: 81959). EMSP-81959-2004, prepared by Sandia National Laboratories for the U.S. Department of Energy, Washington, D.C.

Kalmykov SN and GR Choppin. 2000. "Mixed $\mathrm{Ca}^{2+} / \mathrm{UO}_{2}{ }^{2+} / \mathrm{CO}_{3}{ }^{2-}$ Complex Formation at Different Ionic Strengths.” Radiochimica Acta 88:603-606.

Kelly SD, KM Kemner, and SC Brooks. 2007. "X-Ray Absorption Spectroscopy Identifies CalciumUranyl-Carbonate Complexes at Environmental Concentrations." Geochimica et Cosmochimica Acta 71(4):821-834.

Kirkbride RA, PJ Certa, TM Hohl, AM Johnson, and RS Wittman. 2005. Hanford Tank Waste Operations Simulator Model Data Package for the Development Run for the Refined Target Case. RPP-RPT-23412, Revision 0A, CH2M HILL Hanford Group, Inc., Richland, Washington.

Knepp AJ. 2002. Field Investigation Report for Waste Management Area B-BX-BY. RPP-10098, CH2M HILL Hanford Group, Inc., Richland, Washington.

Korte NE, J Skopp, WH Fuller, EE Niebla, and BA Alesii. 1976. "Trace Element Movement in Soils: Influence of Soil Physical and Chemical Properties." Soil Science Journal 122:350-359.

Krauskopf KB. 1979. Introduction to Geochemistry. McGraw-Hill Book Company, New York. 
Krupka KM and RJ Serne. 1998. Effects on Radionuclide Concentrations by Cement/Ground-Water Interactions in Support of Performance Assessment of Low-Level Radioactive Waste Disposal Facilities. NUREG/CR-6377, U.S. Nuclear Regulatory Commission, Washington, D.C.

Krupka KM and RJ Serne. 2002. Geochemical Factors Affecting the Behavior of Antimony, Cobalt, Europium, Technetium, and Uranium in Vadose Sediments. PNNL-14126, Pacific Northwest National Laboratory, Richland, Washington.

Krupka KM, WJ Deutsch, MJ Lindberg, KJ Cantrell, NJ Hess, HT Schaef, and BW Arey. 2004. Hanford Tanks 241-AY-102 and 241-BX-101: Sludge Composition and Contaminant Release Data. PNNL-14614, Pacific Northwest National Laboratory, Richland, Washington.

Krupka KM, HT Schaef, BW Arey, SM Heald, WJ Deutsch, MJ Lindberg, and KJ Cantrell. 2006a. "Residual Waste from Hanford Tanks 241-C-203 and 241-C-204. 1. Solids Characterization." Environmental Science \& Technology 40(12):3749-3754.

Krupka KM, CF Brown, HT Schaef, SM Heald, MM Valenta, and BW Arey. 2006b. "Rhenium Uptake as Analogue for ${ }^{99} \mathrm{Tc}$ by Steel Corrosion Products." In Proceedings of the 11th International High-Level Radioactive Waste Management Conference (IHLRWM), B Sagar (technical program chair), pp. 905-912. American Nuclear Society, La Grange Park, Illinois.

Krupka KM, WJ Deutsch, HT Schaef, BW Arey, SM Heald, MJ Lindberg, and KJ Cantrell. 2007. "Characterization of Solids in Residual Wastes from Underground Storage Tanks at the Hanford Site, Washington, U.S.A.” In Scientific Basis for Nuclear Waste Management XXX, DS Dunn, C Poinssot, and B Begg (eds.), p. 473-482. Materials Research Society Symposium Proceedings Volume 985. Materials Research Society, Warrendale, Pennsylvania.

Langmuir D. 1978. "Uranium Solution-Mineral Equilibria at Low Temperatures with Applications to Sedimentary Ore Deposits.” Geochimica et Cosmochimica Acta 42:547-569.

Langmuir D. 1997. Aqueous Environmental Geochemistry. Prentice Hall, Upper Saddle River, New Jersey.

Leckie JO, MM Benjamin, K Hayes, G Kaufman, and S Altman. 1980. Adsorption/Coprecipitation of Trace Elements from Water with Iron Oxyhydroxides. EPRI RP-910, Electric Power Research Institute, Palo Alto, California.

Lieser KH. 1993. "Technetium in the Nuclear Fuel Cycle, in Medicine and in the Environment." Radiochimica Acta 63:5-8.

Lieser KH and TH Steinkopff. 1989. "Chemistry of Radioactive Cesium in the Hydrosphere and in the Geosphere.” Radiochimica Acta 46:39-47.

Lindberg MJ and WJ Deutsch. 2003. Tank 241-AY-102 Data Report. PNNL-14344, Pacific Northwest National Laboratory, Richland, Washington.

Lindsay WL. 1979. Chemical Equilibria in Soils. John Wiley \& Sons, New York. 
Lindsay WL, M Sadiq, and KL Porter. 1981. "Thermodynamics of Inorganic Nitrogen Transformation." Soil Science Society of America Journal 45:61-66.

Lloyd JR and LE Macaskie. 1996. "A Novel Phoshor Imager-Based Technique for Monitoring the Microbial Reduction of Technetium.” Applied and Environmental Microbiology 62(2):578-582.

Lloyd JR, HF Nolting, VA Solé, K Bosecker, and LE Macaskie. 1998. “Technetium Reduction and Precipitation by Sulfate-Reducing Bacteria.” Geomicrobiology Journal 15:45-58.

Lloyd JR, JA Cole, and LE Macaskie. 1997. "Reduction and Removal of Heptavalent Technetium from Solution by Escherichia coli.” Journal of Bacteriology 179(6):2014-2021.

Lloyd JR, J Ridley, T Khizniak, NN Lyalikova, and LE Macaskie. 1999. "Reduction of Technetium by Desulfovibrio desulfuricans: Biocatalyst Characterization and Use in a Flow through Bioreactor." Applied and Environmental Microbiology 65:2691-2696.

Lloyd JR, VA Sole, CVG Van Praagh, and DR Lovley. 2000. "Direct and Fe(II)-Mediated Reduction of Technetium by Fe(III)-Reducing Bacteria." Applied and Environmental Microbiology 66:3743-3749.

Lundqvist R. 1982. "Hydrophilic Complexes of the Actinides. I. Carbonates of Trivalent Americium and Europium." Acta Chemica Scandinavica Series A-Physical And Inorganic Chemistry 36 (9):741-750.

MacNaughton MG. 1977. “Adsorption of Chromium(VI) at the Oxide-Water Interface." In Biological Implications of Metals in the Environment, H Drucker and RF Wildung (eds.), pp. 244-253. CONF-750929, National Technical Information Service, Springfield, Virginia.

Mazzi U. 1989. "The Coordination Chemistry of Technetium in its Intermediate Oxidation States." Polyhedron 8(13-14):1683 1688.

McGrail BP, DH Bacon, WL Ebert, and KP Saripalli. 2000. A Strategy to Conduct an Analysis of the Long-Term Performance of Low-Activity Waste Glass in a Shallow Subsurface Disposal System at Hanford. PNNL-11834 Revision 1, Pacific Northwest National Laboratory, Richland, Washington.

McKinley JP, JM Zachara, SC Smith, and GD Turner. 1995. "The Influence of Uranyl Hydrolysis and Multiple Site-Binding Reactions on Adsorption of U(VI) to Montmorillonite." Clays and Clay Minerals 43(5):586-598.

McKinney SG. 2004. Analytical Results for Tank 241-C-106 Solid Clam Shell Samples Supporting Closure Action. RPP-20264, Rev. 0, CH2M HILL Hanford Group, Inc., Richland, Washington.

Meacham JE, AB Webb, MG Plys, SJ Lee, JM Grigsby, PG Heasler, JL Bryant, JJ Toth, and PM Daling. 1996. Safety Criteria for the Organic Watch List Ranks at the Hanford Site. WHC-SD-WM-SARR-033, Rev. 1, Westinghouse Hanford Company, Richland, Washington.

Meyer RE, WD Arnold, and FI Case. 1985. Valence Effects on the Adsorption of Nuclides on Rocks and Minerals II. NUREG/CR-4114, U.S. Nuclear Regulatory Commission, Washington, D.C. 
Nakayama E, T Kumamoto, S Tsurubo, and T Fujinaga. 1981. "Chemical Speciation of Chromium in Sea Water. Part 2. Effects of Manganese Oxides and Reducible Organic Materials on the Redox Processes of Chromium." Analytica Chimica Acta 130:401-404.

Noll B, S Seifert, and R Münze. 1980. "New Tc(IV) Compounds with Nitriloacetic Acid." Radiochemical and Radioanalytical Letters 43:215-218.

Nordstrom DK and JL Munoz. 1985. Geochemical Thermodynamics. The Benjamin/Cummings Publishing Co., Inc., Menlo Park, California.

Nriagu JO and E Nieboer. 1988. Chromium in the Natural and Human Environments. Volume 20 in The Wiley Series in Advances in Environmental Science and Technology, JO Nriagu (series ed.). John Wiley \& Sons, New York.

Onishi Y, RJ Serne, EM Arnold, and CE Cowan, and FL Thompson. 1981. Critical Review: Radionuclide Transport, Sediment Transport, and Water Quality Mathematical Modeling; and Radionuclide Adsorption/Desorption Mechanisms. NUREG/CR-1322, U.S. Nuclear Regulatory Commission, Washington, D.C.

Palmer CD and PR Wittbrodt. 1991. "Processes Affecting the Remediation of Chromium-Contaminated Sites.” Environmental Health Perspectives 92:25-40.

Palmer CD and RW Puls. 1994. Natural Attenuation of Hexavalent Chromium in Groundwater and Soils. EPA/540/S 94/505, U.S. Environmental Protection Agency, Ada, Oklahoma.

Paquette J and WE Lawrence. 1985. "A Spectroelectrochemical Study of the Technetium(IV)/

Technetium(III) Couple in Bicarbonate Solutions.” Canadian Journal of Chemistry 63:2369-2373.

Parker D. 2006a. Retrieval Data Report for Single-Shell Tank 241-C-106. RPP-RPT-20577, Revision 1, CH2M HILL Hanford Group, Inc., Richland, Washington.

Parker D. 2006b. Retrieval Data Report for Single-Shell Tank 241-C-202. RPP-RPT-29095, CH2M HILL Hanford Group, Inc., Richland, Washington.

Parker D. 2006c. Retrieval Data Report for Single-Shell Tank 241-C-203. RPP-RPT-26475 Revision 1, CH2M HILL Hanford Group, Inc., Richland, Washington.

Payne TE and TD Waite. 1991. "Surface Complexation Modeling of Uranium Sorption Data Obtained by Isotope Exchange Techniques." Radiochimica Acta 52-3:487-493.

Pierce EM, BP McGrail, EA Rodriguez, HT Schaef, KP Saripalli, RJ Serne, KM Krupka, PF Martin, SR Baum, KN Geiszler, LR Reed, and WJ Shaw. 2004. Waste Form Release Data Package for the 2005 Integrated Disposal Facility Performance Assessment. PNNL-14805, Pacific Northwest National Laboratory, Richland, Washington.

Pitzer KS. 1991. "Ion Interaction Approach: Theory and Data Correlation." In Activity Coefficients in Electrolyte Solutions, KS Pitzer (ed.), Chap. 3, pp. 75-153. CRC Press, Boca Rotan, Florida. 
Pitzer KS and G Mayorga. 1973. "Thermodynamics of Electrolytes. II. Activity and Osmotic Coefficients for Strong Electrolytes with One or Both Ions Univalent.” J. Phys. Chem. 77:2300-2308.

Qafoku N, JM Zachara, C Liu, PL Gassman, O Qafoku, and SC Smith. 2005. "Kinetic Desorption and Sorption of U(VI) During Reactive Transport in a Contaminated Hanford Sediment." Environmental Science and Technology 39(9):3157-3165.

Rai D, JM Zachara, AP Schwab, RL Schmidt, DC Girvin and JE Rogers. 1984. Chemical Attenuation Rates, Coefficients, and Constants in Leachate Migration. Vol. 1: A Critical Review. EA-3356, Vol. 1, Electric Power Research Institute, Palo Alto, California.

Rai D, BM Sass, and DA Moore. 1987. "Chromium(III) Hydrolysis Constants and Solubility of Chromium(III) Hydroxide.” Inorganic Chemistry 26 (3):345-349.

Rai D, JM Zachara, LE Eary, CC Ainsworth, FE Amonette, CE Cowin, RW Szelmeczka, CT Resch, RL Schmidt, SC Smith, and DC Girvin. 1988. Chromium Reactions in Geologic Material. EA-5741, Electric Power Research Institute, Palo Alto, California.

Rai D, AR Felmy, NJ Hess, VL LeGore, and DE McCready. 2002. "Thermodynamics of the U(VI)$\mathrm{Ca}^{2+}-\mathrm{Cl}^{-}-\mathrm{OH}^{-}-\mathrm{H}_{2} \mathrm{O}$ System: Solubility Product of Becquerelite." Radiochimica Acta 90:495-503.

Rard JA, MH Rand, G Anderegg, and H Wanner. 1999. Chemical Thermodynamics Volume 3: Chemical Thermodynamics of Technetium. North-Holland, Elsevier Science Publishing Company, Inc., New York.

RCRA - Resource Conservation and Recovery Act. 1976. Public Law 94-580, as amended, 90 Stat. 2795, 42 USC 6901 et seq.

Read D, TA Lawless, RJ Sims, and KR Butter. 1993. "Uranium Migration through Intact Sandstone Cores." Journal of Contaminant Hydrology 13:277-289.

Reardon EJ. 1992. "Problems and Approaches to the Prediction of the Chemical Composition in Cement/Water Systems.” Waste Management 12:221-239.

Richard FC and ACM Bourg. 1991. "Aqueous Geochemistry of Chromium: A Review." Water Research 25:807-816.

Riley RG and CA Lopresti. 2001. Data Catalog for Models Simulating Release of Contaminants from Hanford Site Waste Sources. PNNL-13666, Pacific Northwest National Laboratory, Richland, Washington.

Riley RG and CA Lopresti. 2003. Data Catalog for Models Simulating Release of Contaminants from Hanford Site Waste Sources. PNNL-13666 Rev. 1, Pacific Northwest National Laboratory, Richland, Washington.

Riley RG, CA Lopresti, and DW Engel. 2006. Release Data Package for Hanford Site Assessments. PNNL-15965, Pacific Northwest National Laboratory, Richland, Washington. 
Ritherdon B, C Phelps, H Neff, AG Sowder, and SB Clark. 2003. "Stability of U(VI) Solid Phases in the $\mathrm{U}(\mathrm{VI})-\mathrm{Ca}^{2+}-\mathrm{SiO}_{2}-\mathrm{OH}$ System.” Radiochimica Acta 91(2):93-96.

Russell CD, RC Crittenden, and AG Cash. 1980. "Determination of Net Ionic Charge on Tc-99m DTPA and Tc-99m EDTA by a Column Ion-Exchange Method.” Journal of Nuclear Medicine 21:354-360.

Sass BM and D Rai. 1987. "Solubility of Amorphous Chromium(III)-Iron(III) Hydroxide Solid Solutions." Inorganic Chemistry 26(14):2228-2232.

Schulz WW, and JD Navratil. 1984. Science and Technology of Tributyl Phosphate, Vol. I. Synthesis, Properties, Reactions and Analysis. CRC Press, Boca Raton, Florida.

Shanbhag PM and GR Choppin. 1981. "Binding of Uranyl by Humic Acid." Journal of Inorganic and Nuclear Chemistry 43:3369-3375.

Sharma AK, SA Clauss, GM Mong, KL Wahl, and JA Cambell. 1998. "Analysis and Quantification of Organic Acids in Simulated Hanford Tank Waste and Hanford Tank Waste." Journal of

Chromatography A 855:101-107.

Smith RM, and AM Martell. 1976. Critical Stability Constants, Volume 4: Inorganic Complexes. Plenum Press, New York, New York.

Smith RM, AE Martell, and RJ Motekaitis. 1997. NIST Critically Selected Stability Constants of Metal Complexes Database. Version 4.0. NIST Standard Reference Database 46, National Institute of Standards and Technology, Gaithersburg, Maryland. (includes personal computer software database)

Sparks ST and SE Long. 1987. The Chemical Speciation of Technetium in the Environment: A Literature Study. DOE/RW 88.098 (UKAEA/DOE Radiological Protection Research Programme Letter AERE-R 12743), Harwell Laboratory, Oxfordshire, England.

Sposito G. 1989. The Chemistry of Soils. Oxford University Press, New York.

Stumm W and JJ Morgan. 1981. Aquatic Chemistry. An Introduction Emphasizing Chemical Equilibria in Natural Waters. John Wiley \& Sons, New York.

Thibault DH, MI Sheppard, and PA Smith. 1990. A Critical Compilation and Review of Default Soil Solid/Liquid Partition Coefficients, $K_{d}$, for Use in Environmental Assessments. AECL-10125, Whiteshell Nuclear Research Establishment, Atomic Energy of Canada Limited, Pinawa, Canada.

Tuli JK. 2004. "Nuclear Wallet Cards for Radioactive Nuclides.” National Nuclear Data Center, Brookhaven National Laboratory, Upton, New York. Available at http://www.nndc.bnl.gov/wallet/wallet4radioactivenuclides.pdf (July 2007).

Turner GD, JM Zachara, JP McKinley, and SC Smith. 1996. "Surface-Charge Properties and $\mathrm{UO}_{2}{ }^{2+}$ Adsorption of a Subsurface Smectite." Geochimica et Cosmochimica Acta 60(18):3399-3414. 
U.S. Environmental Protection Agency (EPA). 1996. "Method 3050B. Acid Digestion of Sediments, Sludges, and Soils." Revision 2(December 1996). In Test Methods for Evaluating Solid Wastes: Physical/Chemical Methods, EPA SW-846, Third Ed., Vol. I, Section A, Chapter 3 (Inorganic Analytes), pp. 3050B-1-3050B-12, U.S. Environmental Protection Agency, Office of Solid Waste and Emergency Response, Washington, D.C. Available at: http://www.epa.gov/epaoswer/hazwaste/test/pdfs/3050b.pdf.

U.S. Environmental Protection Agency (EPA). 1999a. Understanding Variation in Partition Coefficient, $K_{d}$, Values: Volume I. The $K_{d}$ Model, Methods of Measurement, and Application of Chemical Reaction Codes. EPA 402-R-99-004A, U.S. Environmental Protection Agency, Washington, D.C.

U.S. Environmental Protection Agency (EPA). 1999b. Understanding Variation in Partition Coefficient, $K_{d}$, Values: Volume II. Review of Geochemistry and Available $K_{d}$ Values for Cadmium, Cesium, Chromium, Lead, Plutonium, Radon, Strontium, Thorium, Tritium $\left({ }^{3} \mathrm{H}\right)$, and Uranium.

EPA 402-R-99-004B, U.S. Environmental Protection Agency, Washington, D.C.

U.S. Environmental Protection Agency (EPA). 2004. Understanding Variation in Partition Coefficient, $K_{d}$, Values: Volume III. Review of Geochemistry and Available $K_{d}$ Values for Americium, Arsenic, Curium, Iodine, Neptunium, Radium, and Technetium. EPA 402-R-04-002C, U.S. Environmental Protection Agency, Washington, D.C.

Um W, RJ Serne, and KM Krupka. 2004. "Linearity and Reversibility of Iodide Adsorption on Sediments from Hanford, Washington under Water Saturated Conditions." Water Research 38:2009-2016.

Van der Weijden CH and M Reith. 1982. "Chromium(III)-Chromium(VI) Interconversions in Seawater." Marine Chemistry 11:565-572.

Waite TD, TE Payne, JA Davis, and K Sekine. 1992. Alligators Rivers Analogue Project. Final Report Volume 13. Uranium Sorption. DOE/HMIP/RR/92/0823, SKI TR 92:20-13, Australian Nuclear Science and Technology Organisation, Menai, Australia.

Waite TD, JA Davis, TE Payne, GA Waychunas, and N Xu. 1994. "Uranium(VI) Adsorption to Ferrihydrite: Application of a Surface Complexation Model." Geochimica et Cosmochimica Acta 58(24):5465-5478.

Wakoff B and KL Nagy. 2004. "Perrhenate Uptake by Iron and Aluminum Oxyhydroxide: An Analogue for Pertechnetate Incorporation in Hanford Waste Tank Sludges." Environmental Science and Technology 38(6):1765-1771.

Wellman DM, SV Mattigod, BW Arey, MI Wood, and SW Forrester. 2005. "In-Situ Identification of Uranium Minerals in Concrete." Geochimica et Cosmochimica Acta 69:A468, Suppl. S.

Wharton MJ, B Atkins, JM Charnock, FR Livens, RAD Pattrick, and D Collison. 2000. "An X-ray Absorption Spectroscopy Study of the Coprecipitation of Tc and Re with Mackinawite (FeS)." Applied Geochemistry 15:347-354. 
White AF and MF Hochella Jr. 1989. "Electron Transfer Mechanism Associated with the Surface Dissolution and Oxidation of Magnetite and Ilmenite." Water-Rock Interaction WRI 6, DL Miles (ed.), pp. 765-768. A. A. Balkema, Rotterdam, The Netherlands.

White MD and M Oostrom. 2003. STOMP Subsurface Transport Over Multiple Phases Version 3.0 User's Guide. PNNL-14286, Pacific Northwest National Laboratory, Richland, Washington.

Whitehead DC. 1984. "The Distribution and Transformation of Iodine in the Environment." Environment International 10:321-339.

Wildung RE, KM McFadden, and TR Garland. 1979. "Technetium Sources and Behavior in the Environment.” Journal of Environmental Quality 8:156-161.

Wildung RE, YA Gorby, KM Krupka, NJ Hess, SW Li, AE Plymale, JP McKinley, and JK Fredrickson. 2000. "Effect of Electron Donor and Solution Chemistry on the Products of the Dissimilatory Reduction of Technetium by Shewanella putrefaciens.” Applied and Environmental Microbiology 66:2452-2460.

Yamamura T, A Kidtamura, A Fukui, S Nishikawa, T Yamamoto, and H Moriyama. 1998. "Solubility of U(VI) in Highly Basic Solutions.” Radiochimica Acta 83:139-146.

Zachara JM, CC Ainsworth, GE Brown, Jr., JG Catalano, JP McKinley, O Qafoku, SC Smith, JE Szecsody, SJ Traina, and JA Warner. 2004. "Chromium Speciation and Mobility in a High Level Nuclear Waste Vadose Zone Plume.” Geochimica et Cosmochimica Acta 68(1):13-30.

Zachara JM, SM Heald, B-H Jeon, RK Kukkadapu, C Liu, JP McKinley, AC Dohnalkova, and DA Moore. 2007a. "Reduction of Pertechnetate [Tc(VII)] by Aqueous Fe(II) and the Nature of Solid Phase Redox Products." Geochimica et Cosmochimica Acta 71:2137-2157.

Zachara JM, CF Brown, JN Christensen, PE Dresel, SD Kelly, C Liu, JP McKinley, RJ Serne, and W Um. 2007b. A Site Wide Perspective on Uranium Geochemistry at the Hanford Site. PNNL-17031, Pacific Northwest National Laboratory, Richland, Washington.

Zhang PC, JL Krumhansl, and PV Brady. 2000. "Boehmite Sorbs Perrhenate and Pertechnetate." Radiochmicia Acta 88(6): 369-373. 


\section{Distribution}

DOE Office of River Protection

R. W. Lober

H6-60

CH2M HILL Hanford Group, Inc.

F. M. Mann

H6-03
Pacific Northwest National Laboratory

R. W. Bryce

K6-75

K. M. Krupka

K6-81

Hanford Technical Library

P8-55 